LEOPOLDO STEFANNO GONÇALVES LEONE LOUVEIRA

\title{
A ESFERA DA VIDA PRIVADA DO CIDADÃO COMO LIMITE À INTERFERÊNCIA DO DIREITO PENAL: A QUESTÃO DA PORNOGRAFIA INFANTIL
}

Dissertação de Mestrado Orientadora: Professora-Doutora JANAINA CONCEIÇÃO PASCHOAL

FACULDADE DE DiREITo DA UnIVERSIDADE DE SÃo PAULO

SÃo PAULO

2013 


\title{
A ESFERA DA VIDA PRIVADA DO CIDADÃO COMO LIMITE À INTERFERÊNCIA DO DIREITO PENAL: A QUESTÃO DA PORNOGRAFIA INFANTIL
}

\begin{abstract}
Dissertação de mestrado, sob orientação da Professora-Doutora Janaina Conceição Paschoal, apresentada ao Departamento de Direito Penal, Medicina Forense e Criminologia, da Faculdade de Direito da Universidade de São Paulo, como requisito parcial à obtenção do título de Mestre em Direito.
\end{abstract}

FACULDADE DE DiREITO DA UNIVERSIDADE DE SÃo PAUlo São Paulo 
BANCA EXAMINADORA

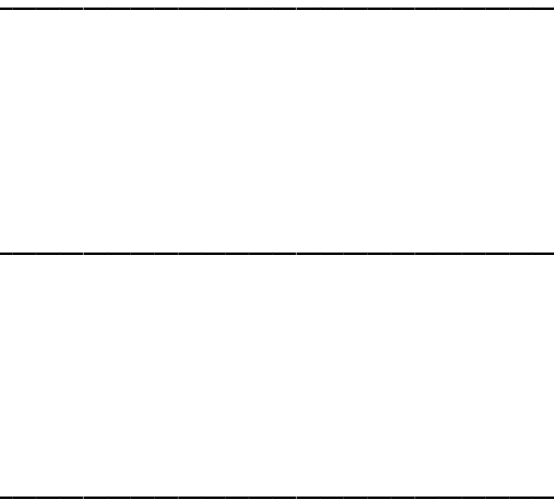


À minha querida tia ANA Augusta (in memorian), pelo exemplo de ser humano e por ter contribuído pelo despertar da minha paixão pelo mundo da leitura. 


\section{AGRADECIMENTOS}

Como não se faz uma dissertação sozinho, ainda mais para a obtenção do honroso título de mestre na prestigiosa e tradicional Faculdade de Direito do Largo de São Francisco, são necessárias algumas palavras de agradecimento dirigidas àqueles que me auxiliaram, cada qual a seu modo, no árduo caminho percorrido até a finalização do trabalho.

Em primeiro lugar, não poderia deixar de mencionar o apoio, as dicas, as sugestões, o carinho, as broncas, a paciência e a compreensão de minha orientadora, JANAINA CONCEIÇÃO PASCHOAL. Desde o primeiro momento em que mantivemos contato, quando comecei a frequentar os bancos da pós-graduação como aluno especial no início de 2009, já foi possível notar o denodo, a entrega, o preparo e a vocação voltados ao nobre exercício do magistério. Isso sem contar o vigor e a honestidade intelectuais, além da capacidade técnica e da lhaneza no trato pessoal. Muito obrigado.

Em seguida, agradeço, de coração, todo o amor, o carinho, o apoio e, principalmente, a paciência e compreensão da ElAINE, minha companheira e mulher da minha vida. Espero que todo o esforço e o tempo dispensados durante os meses de elaboração desse trabalho sejam recompensados. Obrigado, Amore.

Agradeço meus pais MARIA JOSÉ e RICARDO, pelo amor incondicional e por acreditarem em mim desde sempre.

Agradeço, também, à minha amiga e colega de escritório HELOISA ESTELLITA, pela inestimável ajuda desde o ingresso na Pós-gradução (quando da elaboração do Projeto de Pesquisa) até a revisão final. A dedicação de HELOISA ao universo acadêmico foi um dos fatores que me estimularam a encarar o desafio.

Aproveito para agradecer aos demais Professores do Departamento de Direito Penal do Largo de São Francisco que me auxiliaram durante o cumprimento dos créditos, especialmente 
MIGUEL REALE JÚNIOR e MARIÂNGELA GOMES MAGALHÃES. Estendo os agradecimentos aos componentes da Banca de Qualificação, Professores HELENA REGINA LOBO DA COSTA e LUIZ ROBERTO CICOGNA FAGGIONI, pelas valiosas dicas naquele momento difícil.

Agradeço ao Professor LUÍS GRECO, que, em palestra proferida em outubro de 2009 juntamente com o Prof. SCHÜNEMANN, fez despertar meu interesse pelo tema objeto desse trabalho. O grupo de estudos organizado por LUÍS, em julho de 2010 no Rio de Janeiro, do qual participei em companhia de HELOISA, também foi importante para as ideias aqui desenvolvidas.

Agradeço a ajuda, seja por meio de conversas ou trocas de ideias, de meus colegas de Pósgraduação, especialmente THAIS, RITA, DIVANIRA, HEIDI, TATIANA e BRUNO.

Obrigado também à MARIA EMÍLIA, pela gentileza em ter emprestado sua tese de doutoramento, relativa à violência sexual contra crianças e adolescentes, para análise.

Agradeço aos amigos RENATO VIEIRA e ANDRÉ KEHDI, pelo companheirismo e por terem, de alguma forma, dividido as agruras da elaboração de uma dissertação.

Agradeço aos colegas de escritório, especialmente a ALBERTO TORON, que sempre me motivou a trilhar o caminho acadêmico, apesar da correria do dia a dia. Também merecem menção especial KHEIRALLAH, estagiário e os ex-colegas de escritório LILIANA, pela troca de ideias, GAUTHAMA, (tradução de artigo em italiano).

Um agradecimento também à minha querida amiga e colega de escritório ALEXANDRA SZAFIR, pelo exemplo de humanidade, combatividade e valores que norteiam desde sempre o meu exercício diário da advocacia criminal.

Agradeço, por fim, aos meus sogros TÂNIA e EDUARDO, pelo carinho e por terem auxiliado nas traduções de textos em italiano e alemão. 
"Como ser físico, o homem é governado por leis invariáveis do mesmo modo que os outros corpos. Como ser inteligente, o homem viola incessantemente as leis que Deus criou, e modifica as que ele próprio estabeleceu." (MONTESQUIEU, o espírito das leis)

"O castigo tem por finalidade tornar melhor aquele que castiga - aí está o último recurso para os defensores do castigo." (NIETZSCHE, Genealogia da moral) 


\section{RESUMO}

A dissertação analisa a questão dos limites ao poder estatal de interferência por meio do Direito Penal na vida dos cidadãos quando em jogo elementos de sua esfera íntima, mais precisamente, o exercício da sexualidade humana. Sob o pano de fundo do exame dos diversos aspectos jurídicos relacionados à pornografia infantil, o estudo busca verificar de que forma os discursos do "combate ao abuso infantil" e da "luta contra a pedofilia" podem estar ancorados em critérios meramente moralizantes, dando guarida à criação de tipos penais desprovidos de legitimidade. Parte-se de uma abordagem introdutória a respeito da relação entre Direito e Moral - incluídas aí as noções de moral social e moral sexual -, trazendo um retrato da evolução da matéria até a forma liberal de disciplinar o assunto, sem a influência de tabus religiosos ou éticos. A despeito da tentativa de mudança de paradigmas do chamado Direito Penal Sexual, com o abandono de antigos critérios de tutela do pudor público e a introdução da noção de dignidade sexual, assentada na autodeterminação sexual, a disciplina jurídicopenal da pornografia infantil vem sendo objeto de patente recrudescimento nas últimas décadas. Com o advento da rede mundial de computadores, a tendência internacional de combate aos crimes cibernéticos levou o legislador brasileiro a editar a Lei n. ${ }^{\circ} 11.829 / 09$, que alterou o Estatuto da Criança e do Adolescente (ECA), para aumentar penas, criar novos tipos penais e incriminar todos os elos da cadeia da produção pornográfica infantil, incluindo as condutas de mera aquisição/posse de material pornográfico infantil real (artigo 241-B) e a pseudopornografia infantil (artigo 241-C). O trabalho analisa até que ponto essas incriminações seriam justificáveis para o fim invocado, visto que, no caso da modalidade simulada, por exemplo, estão ausentes critérios de exclusiva proteção de bens jurídicos, lesividade e ofensividade, reclamados pelo Direito Penal do Fato. Ao final, a figura do pedófilo merecerá um exame específico, apoiado em conceitos médico-científicos, a fim de delimitar qual seria a melhor maneira político-criminal de abordar os portadores dessa parafilia (pena ou tratamento).

PALAVRAS-CHAVE: Direito penal. Moral. Autonomia. Vida Privada. Crimes sexuais. Crianças. Adolescentes. Obsceno. Pornografia Infantil Real. Pornografia Infantil Simulada. Pseudopornografia Infantil. Posse. Internet. Ofensividade. Lesividade. Pedofilia. 


\section{ABSTRACT}

This dissertation analyzes the issues regarding the limits of the state's power in interfering by means of Criminal law in the lives of citizens, when elements of his/her intimate plane are at stake, more precisely, the exercise of human sexuality. In the background of the examination of several legal aspects regarding child pornography, the study seeks to verify by which form speeches of "combating child abuse" and the "fight against pedophilia" might be anchored by merely moralizing criteria, and in turn supporting the creation of crimes lacking legitimacy. Starting off with an introductory approach regarding the relation between Law and morality - here including the notions of social and sexual morality -, and bringing forth a portrait of the evolution of the subject even in its liberal form of disciplining the subject, without the influence of taboos be them religious or ethic. Despite the attempted change in paradigms called Sexual Criminal Law, with the abandonment of old criteria of tutelage of public shame and the introduction of the notion of sexual dignity, based on sexual selfdetermination, the judiciary criminal discipline of child pornography has been subject of manifest recrudescence in the last decades. In the dawn of worldwide net of computers, the international tendency of cyber-crime fighting has led the Brazilian legislator to edit the Law n. ${ }^{\circ} 11.829 / 09$, that altered the Child and Adolescent Statute (ECA), to raise punishment, and create new crimes and incriminate al the links of the child pornography production chain, including those who merely acquire the true pornographic material (article 24-B) and pseudo child pornography (article 241-C). This presentation analizes up to what point these incriminations would be justifiable for the invoked end, since, in she simulated mode, for instance, the criteria of exclusive protection of the legal interest are absent, prejudice and offensiveness, claimed by the Factual Criminal Law. Finaly, the figure of the pedophile deserves a more specific examination, supported by medical scientific concepts, to bound which would be the best political-criminal way to address the carrier of this paraphilia (penalty or treatment).

KEY-WORDS: Criminal Law. Moral. Autonomy. Privacy. Sexual crimes. Children. Teenagers. Obscene. Legitimated child pornography. Simulated child pornography. Pseudochild pornography. Possession. Internet. Offensiveness. Harm. Pedophilia. 


\section{SUMÁRIO}

INTRODUÇÃO

1.1. Direito e moral: considerações introdutórias 21

1.2. Moralidade social 26

1.3. Moral sexual 36

1.3.1. Moral sexual e princípio da alteridade 41

Capitulo 2 - A AUTONOMIA DO INDIVÍDUO. ESFERA NUCLEAR DE PRIVACIDADE INVIOLÁVEL 51

2.1. Notas introdutórias: o liberalismo 52

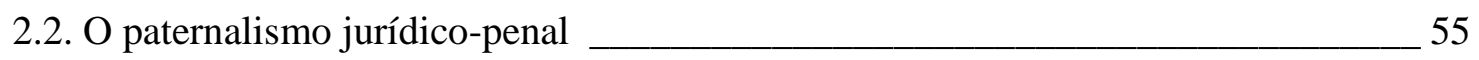

2.3. A "vida privada": a intimidade e a privacidade ___ 62

2.4. As liberdades e seu regime constitucional ______________ 66

2.5. A esfera de autonomia como "núcleo duro" inviolável: critérios possíveis __ 70

Capítulo 3 - O OBSCENO E O DIREITO PENAL 74

3.1. Representações sexuais: breve origem histórica 74

3.2. Conceito dos termos "pornografia" e "obsceno" ___ 78

3.3. O obsceno e o artístico _______________________________ 83

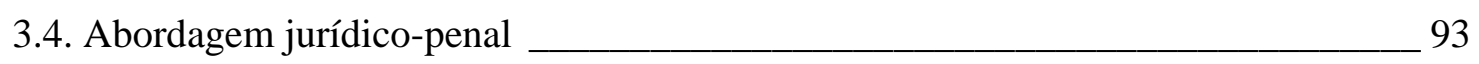


3.4.2. Os delitos de ato obsceno e de escrito ou objeto obsceno (artigos 233 e 234 do Código Penal)

4.1. Liberdade sexual 105

4.2. Crimes sexuais e vítimas menores ou incapazes 110

4.2.1. O bem jurídico tutelado: é possível falar em liberdade/capacidade sexual de menores?

5.1. O conceito de pornografia infantil 128

5.1.1. A questão da idade da vítima 137

5.2. Pornografia infantil e Direito comparado 140

5.2.1. Antecedentes legislativos e evolução no tratamento penal da pornografia infantil

5.2.2. Espanha 145

5.2.3. Itália 150

5.2.4. Portugal 155

5.3. A legislação brasileira 157

5.4. O tráfico, a aquisição, a posse e o armazenamento desse tipo de material 161

5.4.1. O mero acesso a arquivos como figura análoga à da posse de pornografia infantil 166

5.4.2. Legitimação e fundamentos da incriminação 175

5.4.3. O bem jurídico tutelado: individual ou coletivo? 182

5.4.4. Pornografia infantil e "receptação" 188 
5.4.5. Consumo de material pornográfico infantil: estímulo ou arrefecimento à violência sexual efetiva (tese da instigação ou tese da catarse)?

5.5. Pseudopornografia infantil ou pornografia infantil virtual 207

5.5.1. Contextualização: a sociedade da informação, os cybercrimes e a pornografia infantil 207

5.5.2. Pornografia infantil simulada: aspectos jurídicos 213

5.6. Pornografia infantil simulada e análise crítica: o tipo penal é legítimo? 226

Capítulo 6 - PEDOFILIA E PORNOGRAFIA INFANTIL 233

6.1. Pedofilia: breves considerações 232

6.1.1. A figura do pedófilo: criminoso ou doente? 233

6.2. O perfil do pedófilo e do consumidor desse tipo de material: semelhanças e diferenças 241

6.3. Eventuais tratamentos 246 


\section{INTRODUÇÃO}

O trabalho busca tratar da equação entre a utilização da força coercitiva do Estado e as garantias individuais fundamentais do cidadão. Ou seja, até onde podem chegar os sustentáculos do aparato repressivo estatal de forma legítima e condizente com a ordem constitucional? ${ }^{1}$

Com efeito, de diferentes formas, a dogmática jurídico-penal vem buscando criar e aplicar teorias a fim de verificar, primeiro, o quê punir e, em um segundo momento, como punir. Nesse contexto, surge a ideia de que o Direito Penal tem como pressuposto básico eleger (ou tipificar) condutas humanas segundo modelos graduados de gravidade (inclusive, de reprovabilidade), buscando harmonizar o uso da violência legítima com as garantias individuais do cidadão.

As teorias do bem jurídico-penal têm sido interpretadas pelos pensadores na atualidade, como uma busca constante de redução do arbítrio e do subjetivismo por parte do legislador em matéria penal, tendo todos em comum a noção de limitação do direito penal.

Ainda sobre a importância do bem jurídico, vale conferir as palavras de WINFRIED HASSEMER, ao tentar solucionar a questão de se poderiam existir crimes que não afetam um interesse jurídico-penal ${ }^{2}$ : “(...) una prohibición de una conducta bajo amenaza penal que no pudiera remitirse a un bien jurídico sería terror de Estado. Sería nada menos que una intromisión en la libertad humana de actuación respecto a la cual el Estado injerente no puede

\footnotetext{
${ }^{1}$ Calha destacar, de início, as considerações trazidas por JANAINA CONCEIÇÃO PASCHOAL em nota introdutória de trabalho recentemente publicado que, de certa forma, resume o espírito da presente monografia: "Tenho a esperança de que o livro que ora se apresenta ao público tenha mesmo a qualidade de ajudar o leitor a perceber que, por melhores que sejam as intenções, a interferência do Estado no modo de vida do indivíduo, ao final, é sempre deletéria, sobretudo quando tal ingerência ocorre por meio do Direito Penal, que é o braço mais forte do Leviatã”. Ingerência indevida: os crimes comissivos por omissão e o controle pela punição do não fazer. Porto Alegre: Sergio Antonio Fabris, 2011, p. 11 (destaques meus).

${ }^{2}$ Sobre essa questão, é válido alertar que ROXIN possui um ponto de vista um pouco diferente: muito embora defenda a legitimidade e a utilidade da teoria do bem jurídico, este autor, na edição mais recente de seu Tratado de Direito Penal, admite, sim, a possibilidade, em alguns casos especiais à luz da chamada "sociedade de risco" (meio ambiente, direito dos animais e até de embriões humanos e das futuras gerações), de haver normas incriminando condutas sem o referencial do bem jurídico. Cf. destacou ANA ELISA LIBERATORE S. BECHARA. O rendimento da teoria do bem jurídico no direito penal atual. Revista Liberdades, v. 1, $\mathbf{n}^{\mathbf{0}} \mathbf{1}$, p. 25 , São Paulo, mai./ago.2009.
} 
decir con qué fin la lleva a cabo. Dicho 'fin' es el lugar que tradicionalmente ocupa el concepto de bien jurídico. La intervención en la libertad de conducta no tendría algo que la legitimaría”.3

Um dos papéis da dogmática jurídico-penal contemporânea vem sendo mapear os sistemas constitucionais para extrair uma legitimação mínima que dê suporte à previsão e imposição de sanções de caráter penal aos cidadãos somente em casos necessários e excepcionais. Afinal, há outros meios de controle estatal (relacionados ao Direito Administrativo, Civil e Trabalhista) e paraestatal (instituições como a família, comunidades de bairro, sindicatos e demais membros da assim chamada organização civil) para tutelar determinados tipos de interesse de forma, não raras vezes, mais eficientes do que a draconiana previsão e estipulação de penas privativas da liberdade.

Então, ao se analisar dada conduta deve-se questionar sobre a pertinência da incriminação em sentido material, e não meramente formal, como vontade do legislador democraticamente eleito pelo povo.

A evolução do pensamento jurídico-penal levou à elaboração de meios para encontrar no sistema penal - em alguns casos - a fundamentação e, em outros, o limite ao uso do aparato repressivo estatal. Quanto a estes últimos, além da proteção exclusiva de bens jurídicos, podem ser citados importantes princípios, como os da subsidiariedade, da legalidade, e da proporcionalidade.

Porém, alguns problemas surgem quanto à aplicação prática, em casos concretos, da teoria do bem jurídico. Sim, pois não haveria consenso a respeito do próprio conceito e alcance do instituto - que poderia ter uma definição normativa ou então naturalística, tudo a esbarrar na ausência de substrato material acolhido pelo direito constitucional. Outro ponto negativo seria a questão da fundamentação democrática da roupagem criminosa dada pelo

\footnotetext{
${ }^{3}$ HASSEMER, Winfried. ¿Puede haber delitos que no afecten a un bien jurídico penal? Em: HEFENDEL, Roland. La teoría del bien jurídico. Madri: Ed. Marcial Pons, 2007, p.103.
} 
legislador a certos comportamentos que não atinjam, ainda que indiretamente, interesses revestidos de dignidade penal. ${ }^{4}$

Além disso, há outra ordem de reflexões: não raras vezes, o Direito Penal acaba sendo utilizado para reprimir ou evitar condutas de caráter imoral ou que, de alguma forma, firam sentimentos ou valores considerados importantes pelo corpo social.

O assim denominado "moralismo jurídico-penal" encontra eco na asserção de que a imoralidade de uma conduta seria razão relevante para considerá-la um ilícito penal, já que estaríamos diante de um comportamento que afetaria interesses da sociedade.

Nesse aspecto, muito embora não se possa negar uma carga axiológica ínsita em um ordenamento jurídico em determinada época, é vedado ao direito penal tutelar condutas consideradas "imorais" ou "desajustadas", sob pena de instituir um sistema meramente simbólico, destituído de sentido material, afrontando a noção de dignidade da pessoa humana.

Muito além dos princípios da legalidade, proporcionalidade, ofensividade e fragmentariedade do Direito Penal em um Estado Constitucional, verifica-se a necessidade de repensar a criação de critérios ainda mais rigorosos como limites ao poder de incriminação de condutas.

Todos temos o direito de viver a própria vida. Naquilo que se convencionou chamar de intimidade ou de privacidade ${ }^{5}$, o ser humano pode levar a sua vida como melhor the aprouver, desde que sua conduta não surta efeito negativo a interesses alheios.

\footnotetext{
${ }^{4}$ Esse raciocínio foi desenvolvido pela Corte Constitucional Alemã no julgamento que considerou compatível com a Constituição o delito de incesto. A ideia vem estampada no artigo: Tem futuro a teoria do bem jurídico? Reflexões a partir da decisão do Tribunal Constitucional Alemão a respeito do crime de incesto ( $\$ 173$ Strafgesetzbuch), GRECO, Luís, Revista Brasileira de Ciências Criminais, São Paulo, v. 18, nº 82, p.165-185, jan./fev. 2010.

${ }_{5}^{5}$ Interessante questão etimológica trouxe GILBERTO HADDAD JABOUR: “é comum referir-se à vida privada evocando os substantivos intimidade e privacidade. Os dicionaristas mais modernos tratam-nos como sinônimos. Privacidade é anglicismo, veio de privacy. Antes da importação do vocábulo, ao adjetivo privado ou privativo correspondia o substantivo privatividade. No campo prático, invocar um ou outro termo não implica qualquer minoração protetiva". Liberdade de pensamento e direito à vida privada.São Paulo: RT, 2000, p. 255.
} 
Essa esfera, privativa e íntima do indivíduo, é (ou deveria ser) algo indevassável - ou inviolável - e que merece ser respeitada (ou ao menos tolerada) pelo Estado, principalmente quando está em jogo a aplicação do Direito Penal. Nos dizeres de LUÍS GRECO, "principalmente no que diz respeito a questões referentes à chamada 'boa vida', qualquer intervenção estatal significará um desrespeito a essa autonomia, entendida aqui grosseiramente como o direito de viver segundo seu próprio plano de vida (...)" 6

Importante dizer que essa denominada autonomia abarca diversos outros aspectos da personalidade individual, do modo de ser da pessoa. Bem por isso, o Tribunal Constitucional alemão, ao reconhecer a ilegalidade de escuta domiciliar, deixou assentado: "o desenvolvimento da personalidade na esfera nuclear da vida privada pressupõe a possibilidade de expressar eventos internos, como sensações e sentimentos, bem como reflexões, opiniões e experiências de caráter personalíssimo... Pertencem a essa esfera também expressões de sentimento, de experiências inconscientes e formas de manifestação da sexualidade" ${ }^{7}$.

Por óbvio que esse direito à autonomia não é absoluto. Mostra-se preciso apontar até onde vai esse limite impenetrável relativo ao âmbito único do cidadão em detrimento da interferência do poder constituído. Por isso são necessários parâmetros a ser seguidos pelo legislador e intérprete da lei penal. Aqui reside o centro desta monografia.

A maneira mais razoável de desenvolver essa ideia consiste em considerar essa esfera privativa como objeto de uma regra (ou garantia) de proteção do núcleo essencial de direitos fundamentais. Autonomia como uma espécie “núcleo duro", impenetrável em hipótese alguma pelo direito penal, inclusive imune a quaisquer ponderações ou flexibilizações. Algo realmente fora do campo hipotético de incidência da norma penal, visto como sendo o "limite dos limites". 8

\footnotetext{
${ }^{6}$ GRECO, LUÍs, ob. cit., p. 10.

${ }^{7}$ GRECO, LUÍs, idem, p. 11.

${ }^{8}$ Para tanto, deverão ser traçadas eventuais diferenças entre regra e princípio, bem como serão abordadas questões examinadas por HUMBERTO ÁvILA na obra Teoria dos princípios: da definição à aplicação dos princípios jurídicos. 7. a ed., ampl., atual., São Paulo: Malheiros, 2007, p. 181.
} 
Em verdade, a própria noção da esfera nuclear intocável restaria descartada e relegada à inutilidade caso prosperasse esse raciocínio já que, ao fim e ao cabo, em uma sociedade dinâmica qualquer ação pode, ainda que de maneira reflexa, gerar resultados para interesses alheios.

No entanto, o liberalismo clássico - nos moldes da visão de JOHN STUART MILL entende como injustificável a interferência do poder político sem que haja consequências realmente relevantes a outros membros da sociedade. Daí porque, quanto a comportamentos compreendidos no espectro restrito do cidadão, a roupagem jurídica de "ilícito" (ainda mais se for de norma de caráter penal) torna-se indevida, e mais, contrária aos próprios fins do Direito Penal.

Uma vez definidas as hipóteses permitidas de influência estatal, a ideia do presente trabalho será trazer esse denominado "núcleo duro", juntamente com os pressupostos de proteção de bens jurídicos e da ofensividade, para o campo dos limites ao que seria uma sexualidade saudável e despida de quaisquer preconceitos de ordem moral ou ética.

Aí a relevância do segundo grande bloco de estudo a ser desenvolvido, qual seja, a maneira ideal de o Direito Penal lidar com os casos relativos à pornografia infantil, seja quanto às condutas de produção, divulgação e distribuição (tráfico), bem como quanto à posse, aquisição ou armazenamento desse tipo de material, especialmente, em nosso país, com o advento da reforma implementada pela Lei 11.829/08, do Estatuto da Criança e do Adolescente.

Em especial, dar-se-á relevo para a questão da pornografia - esta considerada como toda e qualquer forma de representação (vídeos, figuras, fotos e ilustrações) da sexualidade humana -, principalmente envolvendo crianças e adolescentes, ainda que de maneira virtual ou simulada (que, afinal, é o objeto específico de exame neste trabalho).

Além de buscar apresentar um conceito de material pornográfico, o importante será apontar até que ponto o Estado poderá se intrometer na maneira de expressão de desejos 
sexuais dos cidadãos, com a utilização de seu tentáculo mais rigoroso, qual seja, o monopólio da violência por meio do Direito Penal.

Uma breve incursão sobre o tema do obsceno e a forma de tratamento da legislação repressiva ${ }^{9}$ será valiosa à medida que o assunto sempre foi abordado sob um olhar repleto de preconceitos, como se a sexualidade humana fosse um tipo de tabu para os órgãos de controle estatal.

Em momento posterior, o estudo se enveredará nas disciplinas legislativas a respeito da proteção da criança e do adolescente no direito comparado e no Brasil, com destaque às disposições do Estatuto da Criança e do Adolescente no que atina com a tutela da liberdade e autodeterminação sexuais, bem como, o sadio desenvolvimento desse peculiar grupo de pessoas.

Após exame dos diversos tipos penais, o estudo se voltará a compreender de que forma o Estado brasileiro busca reprimir condutas concernentes à produção, distribuição, circulação de material pornográfico infantil, bem assim, aquelas relativas à aquisição e posse desse tipo de material.

Aqui se revela a principal finalidade deste trabalho: até que ponto é legítimo haver uma previsão legal de crime quanto a pessoas que, de uma forma ou de outra, se sentem atraídas por estímulos visuais contendo crianças ou adolescentes em poses provocantes, ainda que tal material seja apenas simulado ou "montado". 10

Sobre esse ponto em particular, afora a tendência mundial de repressão à facilidade na troca de informações permitida pelos avanços tecnológicos por meio da rede mundial de

\footnotetext{
${ }^{9}$ Pode-se destacar os tipos penais constantes dos artigos 233 e 234 do Código Penal (ato obsceno e escrito obsceno) como maneiras de o poder constituído interferir no modo de ser do cidadão, tudo em nome da proteção ao "pudor público", mesmo que não se saiba exatamente o real sentido de se criminalizar condutas que, a nosso ver, não se revestem de dignidade penal, além de permitidas pelo Estado (por exemplo, compra e venda de material pornográfico em bancas de jornais).

${ }^{10}$ De fato, a redação do artigo 241-C da Lei 8.069/90, com as alterações trazidas pela Lei 11.829/08, não deixa sombra de dúvidas de que o direito brasileiro entende como crime a propalada "pseudopornografia", ou "pornografia infantil virtual", em que não há, nem indiretamente, a imposição de abuso real a qualquer criança ou adolescente.
} 
computadores (internet) - controle este que busca evitar a disseminação de pornografia infantil, por exemplo -, a reforma do ECA (incrementada por um diploma legal decorrente de inegável pressão da opinião pública em razão do relatório da "Comissão Parlamentar Mista de Inquérito da Pedofilia") é marcada por claro caráter moralista. E, como se disse, moral e direito penal não podem se misturar, sob pena de se coroar odioso arbítrio estatal em uma área que, ao fim e ao cabo, deve ser restrita à forma de vida do indivíduo.

O verdadeiro sentido da incriminação repousa na tentativa, em nosso sentir equivocada, de se determinar padrões obrigatórios de comportamentos sexuais. Sim, pois qual a razão para reprimir, com pena de reclusão de um a quatro anos, o cidadão que tem em seu computador figuras montadas (ou simuladas) de crianças ou adolescentes em situação sexual ou pornográfica?

Além do discurso de que tal pessoa seria um abusador em potencial ou então a invocação da proteção da sociedade contra as redes de material pornográfico, aparece a indisfarçável tentativa de ditar quais seriam as condutas honestas (ou "normais") aceitas no vasto campo da sexualidade humana.

Nesse âmbito, as diversas posições doutrinárias invocadas para legitimar referidas incriminações serão abordadas. Desde a tutela da infância e juventude genericamente consideradas (bem jurídico coletivo), passando pelo risco de prática de crimes sexuais contra crianças reais e até pela similitude com o crime de receptação, como se verá, todos os argumentos perfilados são insuficientes para dar sustentação à legitimidade da criminalização da pornografia infantil virtual. Já no tocante ao material pornográfico real - no qual, quando da elaboração das imagens ou vídeo, houve a efetiva ofensa à dignidade sexual e o direito ao livre desenvolvimento de vítimas crianças ou adolescentes -, a questão acaba sendo um pouco mais complexa e, por isso, a consonância desse comportamento com os ditames constitucionais dependerá, a nosso ver, de alguns critérios a serem expostos neste trabalho.

O trabalho buscará demonstrar em que medida algumas incriminações relativas à pornografia infantil - principalmente as que têm por objeto material pornográfico simulado - 
extrapolam os limites entre Direito e Moral, configurando muito mais um traço arbitrário de invadir a autonomia do indivíduo (criminalizando meras fantasias), do que tutelar, efetivamente, os direitos das crianças ou dos adolescentes. 


\section{CApÍtulo 1 - A INFLUÊNCIA DA MORAL NO DIREITO}

Esse capítulo é marcado pela tentativa de apontar, consoante uma abordagem histórica de caráter introdutório, de que forma o poder público constituído no âmbito de um Estado Democrático de Direito busca estabelecer a correta e proporcional criminalização de condutas que poderiam colocar em risco a ordem e a paz sociais.

Com efeito, como o objetivo final do trabalho está relacionado com a crítica a determinados tipos penais que dizem respeito a aspectos bastante íntimos dos cidadãos - já que atina com o exercício da sexualidade -, será fundamental estudar não só a forma como Estado pune algumas condutas, como também até que ponto diretrizes éticas ou morais podem, por si sós, justificar a sanção penal.

De início, será feito um breve apanhado das questões relativas ao direito de punir, à teoria da proteção exclusiva do bem jurídico e dos limites negativos e positivos previstos na Constituição Federal, com destaque à questão da ofensividade como fundamento necessário à intervenção penal legítima.

Após, será essencial o exame das diferenças entre Direito e Moral, a influência mútua entre os conceitos e os reflexos dessa análise no campo da "moral sexual", a fim de verificar até que ponto a existência de critérios morais pode nortear decisões de política criminal.

\subsection{Direito e Moral: considerações introdutórias}

A relação entre Direito e Moral, eventuais distinções ou contraposições entre essas duas ideias, configura um dos dilemas mais antigos que permeiam as discussões da Filosofia do Direito, e será essencial ao objeto do estudo que se pretende elaborar. 
De início, um breve olhar sobre a obra de MIGUEL REALE será de extrema valia para compreender o alcance exato da matéria no campo filosófico. Deixou claro, sobre a eventual contraposição (ou separação) entre Direito e Moral, que "não se pode confundir os dois conceitos, mas devemos separá-los." ${ }^{11}$ Para tanto, algumas teorias foram desenvolvidas com a finalidade de trazer bases sólidas sobre as quais se poderiam traçar diferenças: em primeiro lugar, foi concebida a teoria do 'mínimo ético', de JEREMIAS BENTHAM, pela qual o Direito apenas representa o mínimo de Moral declarado em uma sociedade para sua sobrevivência.

Assim, pode-se afirmar que o Direito não é algo diverso da Moral, mas sim, parte desta, com garantias específicas, de modo que a teoria pode perfeitamente ser reproduzida como a imagem de dois círculos concêntricos, sendo o maior o da Moral e o menor, o do Direito. Haveria, aí, um campo de ação comum, de modo que tudo o que é jurídico é moral, mas nem tudo que é moral é jurídico.

Desde a antiguidade, houve intuição de que Direito e Moral não se confundiam. Desde os pré-socráticos, as relações entre Moral e Direito são focadas por vários ângulos. Exemplificadamente, para os romanos, ninguém deveria sofrer uma pena pelo simples fato de pensar, mais do que isso, nem tudo que é lícito é honesto.

As Reformas Calvinista e Luterana e as lutas no mundo europeu, tiveram influência direta na vida dos cidadãos, que passaram a indagar sobre o respeito aos dogmas religiosos, surgindo, assim, a necessidade de se delimitar da zona de interferência do poder público. ${ }^{12}$

Nessa linha, entendiam que o Direito só deveria cuidar da ação humana depois de exteriorizada, e a Moral, ao que passa no plano na consciência. Enquanto uma ação se desenrola no plano íntimo, ninguém tem o direito de obrigar a fazer ou deixar de fazer alguma

\footnotetext{
${ }^{11}$ REALE, Miguel. Noções preliminares de Direito. $27^{\mathrm{a}}$ ed. São Paulo: Saraiva, 2002, p. 41.

${ }^{12} \mathrm{O}$ mestre mais notável, ainda segundo MIGUEL REALE, foi Thomasius, com uma clara diferenciação prática entre Direito e Moral, sendo esta de "foro íntimo" e aquele de "foro externo". Ob. cit., p. 53.
} 
coisa, de forma que Moral e Direito devem ficar separados, sem possibilidade de invasão recíproca.

Essa ideia inicial de que o ordenamento jurídico só teria legitimidade para disciplinar atos "exteriorizados", ou seja, efetivamente realizados no mundo fenomênico, foi de estrema valia para o desenvolvimento da Teoria Geral do Estado. De fato, o cidadão não pode ser punido pelos seus pensamentos, residindo, aqui, uma relevante característica das diferenças entre os dois conceitos. ${ }^{13}$

De outro lado, também não se poderia deixar de considerar a verificação de que fora a Moral existe o "imoral" (ou contrário ao conjunto de valores éticos de natureza cultural e social), mas também existe o "amoral", ou algo indiferente a ela.

Nesse sentido, alguns tipos de normas jurídicas, como as atinentes aos ditames administrativos do funcionamento de uma sociedade, que simplesmente não contêm juízo de valor aparente, servindo apenas e tão-somente para a fluidez dos serviços da burocracia estatal. Um exemplo comumente citado seria uma regra de trânsito, segundo a qual é proibido fazer conversão em determinado ponto de uma via pública.

Como se vê, esse tipo de norma não pode ser tida como "moral" ou "imoral". O sentido de sua existência diz respeito à necessidade, pura e simples, de organizar o trânsito de veículos naquela localidade. Apenas isso. Saber se essa norma de natureza administrativa está de acordo com os ditames morais, a princípio, não fará diferença alguma, até porque pode ser que no futuro se entenda, por exemplo, por uma questão de conveniência ou contingência específica (a diminuição do número de veículos no local), necessária a autorização de tal conversão.

\footnotetext{
${ }^{13}$ Aliás, o raciocínio pelo qual a moral (ou ética) é algo afeito apenas à esfera íntima do indivíduo, não podendo ser imposta por meio da força estatal - mormente pelo Direito Penal -, servirá de base para o estudo do próximo capítulo, referente à autonomia. Importante realçar que "se o Direito só cuida das ações exteriorizadas, somente aquilo que se projeta no mundo exterior fica sujeito à possível intervenção do Poder Público. Nenhum cidadão pode ser processado pelo simples fato de pensar, nem pode ser obrigado a ter esta ou aquela crença. A coação somente surge no momento em que a atividade do indivíduo se projeta sobre a dos demais indivíduos a ponto de causar-lhes dano.”. REALE, Miguel, ob. cit., p. 54.
} 
Ademais, há os atos jurídicos que são lícitos - portanto, permitidos, autorizados pelo ordenamento jurídico - porém, não do ponto de vista moral. Um exemplo possível seria aquele em que, em uma sociedade civil (ou empresarial), apenas um dos sócios trabalha, se esforça em torno do bem comum, enquanto o outro não despende qualquer ajuda efetiva na condução dos negócios no dia a dia. Se o contrato social prever que os frutos auferidos pela sociedade devem ser divididos de forma igualitária entre ambos, veja-se que o resultado será visto como imoral, ou "injusto", todavia o Direito irá tutelar a situação de qualquer forma a garantir o cumprimento do ajustado contratualmente. ${ }^{14}$

Ainda sobre os conceitos morais e jurídicos, tem-se que a Moral está relacionada com o mundo da cultura espontânea, do comportamento que encontra em si próprio a sua razão de existir. $\mathrm{O}$ ato moral implica a adesão do espírito ao conteúdo da regra. A Moral autêntica só existe quando o sujeito realiza a norma por meio de um "ato espiritual espontâneo", sem qualquer coação.

Isso fica bastante evidente quando, por exemplo, a vontade (consciência) da pessoa ao praticar determinada conduta coincide com as finalidades e os anseios do senso comum do que seria algo virtuoso e condizente com os valores reconhecidos como caros ao desenvolvimento daquela sociedade.

Haveria, aí, a ocorrência de um comportamento espontâneo e que tem fím em si mesmo. Poder-se-ia pensar no caso de alguém que pratica atos de bondade com terceiros não apenas porque é "forçado" pelas instâncias sociais (família, por exemplo), mas porque o senso de justiça assim o determina.

A Moral, para realizar-se, precisa contar com a adesão dos obrigados. Quem pratica um ato, consciente da sua moralidade, aderiu ao mandamento a que obedece. No mundo jurídico é igual? Haverá sempre a coincidência entre a consciência e os ditames/mandamentos da norma? A resposta deve ser que não, necessariamente.

\footnotetext{
${ }^{14}$ REALE, Miguel. Ob. cit., p. 43.
} 
A pessoa pode ser compelida, por ordem judicial, à prática de alguma conduta ( $v . g$., pagamento de uma indenização pelos danos causados em um acidente) - algo que, por óbvio, conclua com a moralidade, afinal, o equilíbrio natural entre as coisas -, no entanto, tal comportamento não seria espontâneo.

Daí por que seria lícito afirmar que a Moral é incompatível com qualquer tipo de violência, força, coação, advindas de terceiros, ou do próprio Estado. Aqui reside uma importante diferença entre ambos os conceitos: a Moral é incoercível, ou seja, não pode ser imposta para atingir determinado fim ético, ao passo que o Direito é coercível, detendo o Estado a prerrogativa de impelir seus cidadãos a dado comportamento. Percebe-se, pois, uma espontânea compatibilidade entre Direito e força, o que não se vê no campo meramente moral. $^{15}$

Ainda sobre a origem do conceito de Ética, conveniente ressaltar a antiga identidade entre as ações morais e a noção de bem, ou de felicidade (ou justiça). Por isso que, no mundo grego, em especial segundo o pensamento aristotélico, falava-se na existência de dois vértices morais: o irracional e o racional, sendo o primeiro aquele relacionado aos sentidos naturais do homem e o segundo, ligado ao controle dos desejos e pensamentos humanos, com destaque para a contemplação da coragem e da verdade. ${ }^{16}$

Mais adiante, surge uma noção um pouco mais desenvolvida sobre o assunto: a diferença entre moralidade e legalidade estaria no caráter de obrigatoriedade de uma ou de outra, de modo que o agir por um dever constitui uma opção moral, ao passo que o comportamento "conforme" uma regra denota respeito a normas jurídicas. O Direito é um

\footnotetext{
${ }^{15}$ MIGUEL REALE utiliza a expressão "bilateralidade atributiva" para definir o alcance de normas jurídicas, algo inexistente na seara da Moral. Tal conceito seria a possibilidade de, em uma relação entre dois sujeitos de direitos, um deles ficar autorizado a pretender, impor, ou fazer, garantidamente, algo, segundo uma proporção intersubjetiva. Ob. cit., p. 51.

${ }^{16}$ Esse raciocínio vem apontado por RENATO DE MELLO JORGE SILVEIRA, em Crimes sexuais: bases críticas para a reforma do direito penal sexual. São Paulo: Quartier Latin, 2008.
} 
conceito cultural, enquanto Ética é conceito de valor. ${ }^{17}$ A ética se corporifica por meio da Moral, enquanto a justiça se faz concreta pelo Direito.

Aqui cabe um esclarecimento: distinção não é isolamento. $\mathrm{O}$ descumprimento de uma regra moral pode gerar remorso (individual) ou desconsideração social (sanção externa, ética), e precisa da norma jurídica, no mais das vezes, para garantir-lhe eficácia.

Após essa breve incursão na distinção entre Moral e Direito, analisemos os conceitos de moralidade social (ou apenas "moral social"), para, depois, adentrar-se no exame do tema mais específico da "moral sexual", matéria afeita ao objeto do estudo.

\subsection{Moralidade social}

Em termos clássicos, o homem precisa buscar a autopreservação da comunidade, daí advindo a moralidade social. Afinal, a imoralidade pode por em risco a coletividade. Assim, justificar-se-iam medidas como a criminalização de condutas para o efetivo controle social.

A influência do pluralismo do corpo social nas sociedades contemporâneas não pode ser descartada, nem ignorada. Ou seja, não existe apriorismo absoluto, nem mesmo em consideração moral. As decisões corretas não são universais, mas sim tomadas a partir de um consenso mínimo. Dessa forma, a penalização de comportamentos apenas seria legítima se lastreada em um consenso racional intersubjetivo. A lei, a rigor, não deveria identificar-se com a moral, porém acaba regulando condutas dentro de uma dada sociedade, sendo de rigor se atentar para o caráter pluralista desta. ${ }^{18}$

\footnotetext{
17 Acerca do conceito de Ética, interessantes as palavras de MARCO SEGRE no sentido de que "para pensarmos Ética, temos que a ter como rigorosamente subjetiva. O que é Ética se não uma hierarquia de valores, uma tentativa de delineamento do 'certo' ou 'errado', do bem ou do mal? Venha ela de um Deus externo, de um estatuto jurídico, de tradições, de observações científicas. Mas certamente, cada subjetividade (cada indivíduo) poderá estabelecer, se quiser (condição de autonomia), sua escala hierárquica de valores." O contexto histórico, semântico e filosófico do princípio de autonomia. Bioética, Brasília, v. 6, no 1, 1998, p.21.

${ }^{18}$ SILVEIRA, RENATO..., ob. cit., p. 119.
} 
Entre essas mais diversas conceituações e definições, o mais importante é termos em mente que, no imenso espectro da moral, o termo pode ser aproximado às noções de Justiça, como um ideal principiológico a ser seguido pelos cidadãos para o alcance de seu desenvolvimento humano.

Sobre a moralidade pública, é fato que seu conceito padece de extrema vagueza, fluidez, indefinição concreta. No mais das vezes, se fala em bons costumes. A moralidade, nesse sentido, significa a tentativa de alcançar padrões como honestidade, decência, retidão, o combate ao rude, feio, obsceno. A incerteza desses conceitos é evidente.

Trazendo a discussão entre a distinção de Direito e Moral para um contexto mais atual, em obra destinada especificamente sobre os reflexos da Lei 11.106/2005 no sistema de crimes sexuais do Código Penal brasileiro ${ }^{19}$, ainda com a redação original de 1940, TADEU ANTÔNIO DIX DA SILVA faz questão de chamar a atenção para a necessidade de afastar ao máximo a influência da moral sobre o ordenamento jurídico.

Defendendo a tese de que é preciso separar ambos os conceitos em um Estado laico, definido como democrático e de Direito, referido autor apresenta os seguintes questionamentos, baseados na lição de dois autores clássicos: “como fica legitimado o Estado a recorrer ao direito penal para a tutela da moral, se já em seu tempo FÜERBACH batia-se contra o que considerava uma 'concepção moralizante' do Direito Penal? Se as palavras 'tão antigas quanto sábias' de Santo Thomáz de Aquino já advertiam o legislador para que não se

\footnotetext{
${ }^{19}$ O referido texto legal teve o mérito de: $i$ ) revogar alguns tipos draconianos do Código Penal, totalmente "em desuso" segundo a cultura contemporânea - por exemplo, o delito de sedução (art. 217), rapto consensual (art. 220), rapto privilegiado (art. 221) e adultério (art. 240) - ii) afastar a causa de aumento de pena em razão de ser o agente casado (art. 226, III, do mesmo Codex) e iii) deslocar o delito de rapto violento (art. 219) para um crime contra a liberdade individual, podendo ser ofendido qualquer pessoa. De outro lado, a reforma operada sobre os artigos 215 e 216 (posse sexual mediante fraude e atentado ao pudor mediante fraude, respectivamente) foi bastante tímida à medida que apenas se extirpou o vocábulo "honesta" de tais modalidades criminosas, mantendo-se a estrutura anterior intacta. Segundo o exame crítico trazido por TADEU ANTONIO DIX SILVA, a despeito do avanço na forma de se encarar os crimes sexuais sob um viés menos moralista ou machista, " $a$ Lei 11.106/2005, com o caráter de reforma pontual que apresenta, não veio a trazer as ansiadas e importantes reformulações no âmbito dos delitos sexuais, mas apenas atendeu essas postulações de maneira tíbia e parcial." Crimes sexuais; reflexões sobre a Nova Lei n. ${ }^{0}$ 11.106/2005. Leme: J.H. Mizuno, 2006, p. 24. Na realidade, a mencionada Lei de 2005 foi apenas a primeira de uma séria de normas responsáveis pela reforma legislativa nesse tema, que culminaria com a ampla reformulação finalmente introduzida pela Lei 12.015/2009.
} 
deixasse 'seduzir pela tentação de tutelar com os meios do direito penal todas as infrações à 'moral objetiva'? ${ }^{20}$

As ideias de LUIGI FERRAJOLI acerca da impossibilidade de interferência direta de critérios meramente morais sobre o Direito também merecem destaque:

"Direito e moral, não só são, como devem permanecer sistemas deontológicos separados. (...) nem todos temos, e nem sequer devemos ter, numa sociedade liberal, as mesmas opiniões ou crenças, ou valores morais ou culturais. É nesta assimetria e nessa recíproca autonomia que se baseia tanto o direito moderno como a ética moderna. Por um lado, a moral laica fundada, em oposição à heteronomia do direito, na autonomia do direito individual, ou seja, na tese metaética da separação da moral e do direito, em virtude da qual o juízo moral sobre um facto é independente da sua qualificação jurídica; por outro., a secularização do direito e laicidade do Estado baseadas na tese metajurídica da separação do direito e da moral, como nem sequer deve refletir uma determinada moral, proibindo um comportamento como crime só porque é considerado pecado". ${ }^{21}$

Mais adiante, em pleno compasso quanto às conclusões a que se buscará chegar na presente monografia, conclui o mesmo autor que "o Estado não tem portanto de se meter na vida moral dos cidadãos, defendendo ou impedindo estilos morais de vida, crenças ideológicas ou religiosas, opções ou atitudes culturais. O seu dever é apenas o de garantir a igualdade, a segurança e os mínimos vitais. (...) É precisamente nesta neutralidade moral, ideológica e cultural, e portanto na sua não invasão da vida privada das pessoas a não ser para proibir condutas que prejudiquem terceiros que reside a laicidade do direito e do Estado liberal.”

Com efeito, a impossibilidade de duas pessoas possuírem experiências sociais idênticas leva à conclusão de que, assim como há considerável heterogeneidade no conjunto de cidadãos

\footnotetext{
${ }^{20}$ SILVA, Tadeu Antonio Dix. Ob. cit., p. 42-43.

${ }^{21}$ FERRAJOLI, Luigi. A questão do embrião entre direito e moral. Revista do Ministério Público. Lisboa: v. 24 , Fascículo 94, ano 24, abr.-jun, 2003, p. 11-12.
} 
de determinada sociedade, também existirá uma gama bastante grande de estandartes de moralidade - ainda mais se for considerado o pluralismo marcante, por exemplo, na sociedade brasileira atual. Nessa conformidade, aparece outra indagação: é lícito justificar-se a intervenção jurídico-penal levando-se em conta a existência de uma "moral social", como elemento suficiente para a criminalização de condutas?

Em outras palavras, em existindo tantas modalidades de moral como diferentes tipos de pessoas, como escolher, em um Estado Democrático de Direito, a moral padrão de uma sociedade sem perder de vista as características essenciais democráticas do respeito à pluralidade e a tolerância ${ }^{22}$

Nesse quadro, não parece viável, ao menos à primeira vista, uma resposta positiva, tanto por tudo que foi até aqui dito - no sentido de que há uma separação clara e intransigível entre Direito e Moral, mormente no tocante a normas penais -, como também no perigo que tal proceder quanto à incriminação de condutas meramente "indesejadas".

No entanto, convém adiantar que nem toda a doutrina comunga dessa ideia. Ainda acerca da moral social, ALESSANDRA GRECO destaca a possibilidade de reconhecer a existência da legitimação de uma conduta moralmente repelida pelo seio social quando o comportamento externo do sujeito transcende publicamente. Daí porque, para essa autora, a assim denominada moral social teria um caráter predominantemente heterônomo, que se revela no momento coercitivo. ${ }^{23}$

Não se fala aqui, da moral absoluta ou do princípio ético, mas sim a proposição da aplicação de critérios de moral social coincidentes com juízo de valor, levando, assim, à aceitação da ideia de que normas sociais podem amparar o uso do sistema repressivo penal, desde que presente o conteúdo de proteção a bens jurídicos.

\footnotetext{
${ }^{22}$ COSTA, Francisco Ilídio Ferreira. Da moral e da religião: ausência de relação destas com o direito penal no Estado Democrático de Direito. Revista do Curso de Direito de Ituiutaba - UEMG - ano 4, nº 8, jul./dez 2001, p. 98.

${ }^{23}$ GRECO, Alessandra Orcesi Pedro; RASSI, João Daniel. 2. ${ }^{a}$ ed. Crimes contra a dignidade sexual. São Paulo: Atlas, 2011, p. 39.
} 
Soma-se a tudo isso outro relevante critério norteador do sopesamento entre Direito e Moral: a questão da laicidade do Estado, ou seja, a necessária ausência de interferência de ideologia de cunho religioso na tomada de decisões quanto a políticas públicas.

O fator que estará sempre em eterna mudança, no mundo secularizado, é a forma como enxergar e propor o problema da doutrina moral a questão da ética laica, um traço marcante da sociedade pós-iluminista.

Isso porque, antes, nas sociedades religiosas, os parâmetros eram outros. É inegável que durante muito tempo, na Europa ocidental, houve uma utilização instrumental do temor a Deus, incutindo na cabeça do povo a mistura entre as noções de pecado e crime, de modo que as políticas públicas governamentais daquele período.

Para sabermos como chegamos à sociedade secularizada em que vivemos, é necessário verificar a predominância de um brocardo segundo o qual não há ensinamento moral que possa prescindir do religioso: ética e religião seriam indissolúveis. Nas palavras de NORBERTO BOBBIO, ao deitar análise sobre o contexto social na Idade Média, "um dos principais argumentos para induzir os homens a obedecer às leis morais é o temor a Deus, não importando se este argumento é adotado com intenções puras pelas Igrejas e por meio de seu magistério ou se, em vez disso, é utilizado pelo Estado para seus fins, isto é, para obter obediente mais fácil a seus comandos". ${ }^{24}$

Nesse sentido, verifica-se que, na Idade Média, havia uma inegável utilização dos dogmas religiosos para impor a vontade do soberano, visando à obediência da população aos comandos emanados do governante. Nota-se uma clara intenção de estreitamento dos vínculos entre o súdito e o príncipe.

No entanto, séculos mais tarde, com o advento da instituição do Estado Moderno, não fazia mais sentido a mistura entre os conceitos de religião e política (Estado). Com isso,

\footnotetext{
${ }^{24}$ BOBBIO, Norberto. Elogio da serenidade: e outros escritos morais. Tradução Marco Aurélio Nogueira. 2. ${ }^{\text {a }}$ ed. São Paulo: Editora Unesp, 2011, p. 164.
} 
busca-se, com os ideais modernos, fundar uma ética objetiva, racional e empírica, ou seja, uma ideologia laica, de caráter não-confessional, despida dos mandamentos e da fé religiosa.

Convém, aqui, destacar um breve parêntese. Utilizando-se ainda das palavras de BOBBIO, um bom medidor do grau de laicidade de um Estado pode ser a capacidade que determinada sociedade dispõe de aceitar, tolerar, respeitar aquelas pessoas que não acreditam em Deus. Ou seja, ao comentar a frase atribuída ao filósofo liberal John Locke no sentido de que "os que negam a existência de Deus não devem ser de modo algum tolerados", o autor italiano expõe a forma de pensamento compatível com um Estado que respeita os ditames de uma sociedade plural e pontuada pela liberdade religiosa, já que "nenhuma das constituições vigentes nos Estados liberais, democráticos e laicos (no sentido de não-confessionais) mantém aquela limitação: na liberdade religiosa também está contida a liberdade de não ter religião alguma". 25

Com efeito, na busca das grandes doutrinas morais da Era Moderna, vale fazer menção ao raciocínio desenvolvido pelo mesmo autor, que aponta para quatro linhas de pensamento a serem destacadas: o jusnaturalismo, os juízos de valor consensus humani generi (a existência de uma regra de conduta comum a toda a humanidade), a teoria kantiana (ou moral/moralista, também denominada ética formal, pela qual tudo aquilo permitido ou proibido é estabelecido por critérios formais) e, por fim, o utilitarismo (muito propalado no mundo saxão, proveniente da tese de BENTHAM). ${ }^{26}$

Por uma questão de falta de tempo e espaço, e também porque esse não é o escopo primordial do presente estudo, se deixará de fazer uma análise mais aprofundada sobre cada uma dessas teorias éticas. De qualquer forma, os pontos mais importantes ao desenvolvimento da dissertação repousam no exame da seguinte questão trazida pelo mesmo autor: "se voltarmos um momento à razão adotada por Locke para excluir os ateus da tolerância, perceberemos que a razão desta exclusão não está no fato de que, não podendo ter como

\footnotetext{
${ }^{25}$ BOBBIO, Norberto. Ob. cit., p. 165.

${ }^{26}$ Ob. cit., p. 168-171. O autor apresenta críticas pontuais, e contundentemente fundamentadas, a cada uma dessas tentativas de elaboração da moral laica que, por questão de espaço, tampouco serão esmiuçadas nesse trabalho.
} 
motivação de sua conduta o temor a Deus, não oferecem qualquer garantia de que serão fiéis à palavra dada ou permanecerão vinculados aos juramentos. Em outros termos, os ateus são perigosos porque não temem o castigo de Deus e, não temendo o castigo de Deus, podem ficar menos dispostos a observar as leis morais". ${ }^{27}$

Ora, não é preciso muito atilamento para perceber que, no estágio atual de evolução da sociedade ocidental, não se pode invocar qualquer tipo de moral baseada na ideia de temor divino como fundamento de um código de ética social. Isso porque, aos olhos da Constituição, pouco importa, inclusive, se o cidadão crê ou não em algum ente superior. Não faz diferença alguma a religião adotada pelo indivíduo, já que "nenhuma das constituições vigentes nos Estados liberais, democráticos e laicos (no sentido de não confessionais) mantém aquela limitação: na liberdade religiosa também está contida a liberdade de não ter religião nenhuma. Em poucas palavras, a tolerância inclui também os ateus". ${ }^{28}$

A conclusão tirada desse raciocínio pode ser resumida na ideia de que, se existe a convicção de não permitir uma distinção entre crentes e não crentes quanto ao direito de professar a sua própria fé, mostra-se plenamente possível legitimar a obediência às leis morais sem invocar ou admitir a existência de Deus. Com isso, preconiza-se a laicidade, em detrimento das antigas acepções de moral social.

Todos esses aspectos relativos à intersecção entre Direito, Moral e Religião são relevantes quando se analisará a aplicação do Direito Penal ao âmbito dos delitos sexuais, à medida que, diante da produção legislativa em matéria penal, com preocupante frequência, o legislador vem utilizando o Direito Penal para escopos extrínsecos à tradicional tarefa de tutelar bens jurídicos (de uma maneira diferente, mais “moderna”, quando comparada a séculos passados).

Segundo SILVIA LARIZZA, "as inclinações a um direito penal que, com o uso da sanção, tende a educar moralmente; que aponta à afirmação de valores éticos; que, com

\footnotetext{
${ }^{27}$ Ob. cit., p. 175.

${ }^{28}$ BOBBIO, Norberto. Ob. cit., p. 165.
} 
inclinação paternalística, quer substituir à pessoa para a persecução de seu próprio interesse; que quer impor uma própria visão religiosa da vida e da morte; que, através da tutela, tende a dar vigor e força a sentimentos difusos - também não prejudiciais entre os quais, sobretudo, de insegurança, são encontrados em normas penais já promulgadas ou em vis de promulgação." ${ }^{29}$

Após alardear a tendência legislativa de ultrapassar os limites da estrita necessidade, destaca a mesma autora que moralismo jurídico e paternalismo entram em campo e põem-se como ulteriores critérios de legitimação da sanção penal. ${ }^{30}$

Ainda consoante a mesma autora, "a laicidade se pode apanhar: na proteção das minorias, em razão da qual a norma penal não pode ser instrumento de tutela de uma concepção moral, ainda que majoritária; na garantia do direito à diversidade (...). Laicidade significa, também, igualdade de todos, a prescindir da diversidade de todos; manifesta-se na possibilidade de exercer a própria fé religiosa, qualquer que esta seja, de manifestar o próprio pensamento livremente (...). Democracia pluralista e laicidade do Estado constituem um binômio indissolúvel, no sentido, ao menos, de que a primeira não pode existir no contexto de um Estado confessional. Pode-se, ainda, corroborar o quanto restou dito afirmando que não há laicidade sem democracia e não há democracia sem laicidade". ${ }^{31}$

Ademais, o abandono do ponto de vista teológico na construção de normas (v.g., a eliminação de tipos penais como a heresia, o crimen magiae), com tranquila segurança, tem levado a uma melhor individualização do dano exterior objetivo e à emersão de um significado de valor-desvalor todo laico-secular, integralmente e exclusivamente "terreno", de muitos aspectos da realidade social.

\footnotetext{
${ }^{29}$ LARIZZA, Silvia. Laicidade e Direito Penal. Em: Direito Penal e Política Criminal no Terceiro Milênio: perspectivas e tendências. D'AVILLA, Fabio Roberto (org.). Pontifícia Universidade Católica do Rio Grande do Sul. Porto Alegre: EdiPucRS, 2009, p. 41.

${ }^{30}$ LARIZZA, Silvia, ob. cit., p. 42. De acordo com seu raciocínio, "os novos empreendedores da moralidade, os novos porta-bandeiras da segurança, os novos cruzados não estão nem um pouco interessados na efetividade da norma. Para estes, mais importante é que a norma tenha absorvido as suas escolhas morais, as suas visões de mundo: se, posteriormente, a norma funcionar ou não, se for efetiva ou não, são questões secundárias".

${ }^{31}$ Ob. cit., p. 42.
} 
A respeito da influência da moralidade sobre o direito penal, convém lembrar, ainda, que o sistema penal, em um Estado de Direito democrático, não pode reprimir a imoralidade em si: equivale a afirmar que a sanção penal não pode ser posta a serviço de preceitos éticos ou morais. ${ }^{32}$

Muito embora, hoje em dia, esse princípio seja acolhido em praticamente todos os ordenamentos jurídico-penais contemporâneos, nem sempre foi assim. É dizer, o processo de laicização (ou secularização) do direito vem sendo permanente, longo e complicado, havendo momentos até de recuos históricos.

Até finais dos anos 1600, a confluência entre os dogmas da religião cristã então dominante no mundo europeu era praticamente inevitável. Ou seja, o Estado punia, com rigorosas sanções penais, qualquer conduta que fosse contrária às regras morais ou religiosas. O direito penal consistia em poderoso instrumento para afirmar concepções desse jaez, punindo-se, com severidade, heresias ou outras práticas "desviantes", tidas como "bruxaria" ou "transcendentais". 33

Claro que, com a quebra de paradigma trazida pelos ventos iluministas do século XVIII, introduziu-se uma ampla mudança de ideias com o enfoque na proteção de bens tutelados pelo direito penal. Com isso, o vínculo racional implementado pelos conceitos de bens jurídicos foi o empurrão necessário à posterior - e inevitável - laicização do direito penal. $^{34}$

\footnotetext{
${ }^{32}$ PAULO QUEIROZ desenvolve interessante raciocínio sobre a relação entre imoralidade e o direito penal: "pode-se dizer que há imoralidades toleráveis, penalmente indiferentes, e há as intoleráveis em face dos danos sociais que produzem, e por isso, e sobretudo por isso, são dignas de assumir significado penal. A imoralidade, enfim, é condição necessária, porém jamais condição por si suficiente para justificar politicamente a intervenção coativa do Estado na vida dos cidadãos." (QUEIROZ, Paulo de Souza. Do caráter subsidiário do Direito penal: lineamentos para um direito penal mínimo. 2. ${ }^{\mathrm{a}}$ ed. Belo Horizonte: Del Rey, 2002, p. 76).

${ }^{33}$ DIX SILVA, Tadeu..., ob. cit., p. 51.

${ }^{34}$ Nesse aspecto, FIANDACA destaca que "a punição da mera imoralidade contrasta (por outro lado) com o conjunto dos princípios materiais que concorrem para formar o conceito de Estado preconfigurado na Constituição" Problematica dell'osceno e tutela Del buon costume, Padova, 1984, p. 99. Apud LARIZZA, Silvia. Ob. cit., p. 48, nota 44.
} 
Em suma, não é (nem deve ser) papel do Estado autodeterminar-se tutor da moralidade; não é função da máquina repressora estatal promover a afirmação de particular concepção ética utilizando a ameaça da privação da liberdade como meio para impor certas fórmulas ideológicas.

Ainda no terreno das intersecções entre moral e direito penal, mas trazendo a discussão mais para a questão se desenvolverá ao longo deste trabalho, é preciso fazer uma breve análise sobre a influência dos aspectos éticos no campo da pornografia infantil.

Com efeito, a disciplina da pornografia infantil reclamou sobre si a atenção da comunidade científica, à exata medida que o espírito informador dessa disciplina legislativa aponta para um significativo distanciamento do direito penal do fato, que pune pelas modificações que o agente provoca no mundo exterior, cujo parâmetro mais relevante e essencial é o critério da ofensividade ou danosidade social. ${ }^{35}$

Em um contexto de tendência de reetização do Direito Penal em outras atividades, no caso da pornografia infantil, tal ideologia serve de suporte como estratégia de combate na luta para um fenômeno de distintos aspectos: assim, ao lado de tipos penais incriminadores de condutas que afetem o desenvolvimento sadio da sexualidade, outras hipóteses de penalização se movem em uma tutela muito antecipada do mesmo bem jurídico, como no delito de detenção de posse de material pornográfico, ainda que virtual, tema em debate na presente monografia. Nessa esfera, é difícil localizar a real ofensividade de determinados comportamentos.

Considerando a influência da moral social sobre a esfera dos delitos objeto de nosso estudo, cabe dizer que, no delito de posse de material envolvendo crianças e adolescentes em contexto sexualizado, nota-se uma tutela um tanto quanto indireta da liberdade sexual do menor $^{36}$, não se verificando, a priori, o efetivo nexo de causalidade estreito entre a conduta do

\footnotetext{
${ }^{35}$ LARIZZA, Silvia, ob. cit., p. 51.

${ }^{36}$ Desde logo, para evitar mal-entendidos, convém esclarecer que em alguns momentos será utilizada, no decorrer da presente monografia, a expressão "menor" para se referir às crianças e adolescentes. O motivo disso, muito além de reforçar alguma posição preconceituosa ou estigmatizante, é tão-somente evitar a exaustiva repetição de
} 
agente e o evento danoso ou arriscado que se busca reprimir com a incriminação. Essa ausência de nexo direto entre o resultado danoso e a conduta de detenção desse tipo de material acaba colocando em xeque a própria legitimidade desse tipo de penalização.

Afinal, a repressão penal a tal comportamento tem como justificativa, ao fim e ao cabo, ao lado da propalada necessidade de proteção do menor, a própria promoção de valores éticomorais reinantes no seio social. Tais aspectos serão retomados, em detalhes, mais adiante no presente trabalho.

Analisados os aspectos gerais a respeito da moralidade social, convém, agora, trazer o tema para um peculiar traço do contexto ético: o conjunto de valores morais aplicáveis ao espectro de suma importância ao ser humano, qual seja, a sexualidade.

\subsection{Moral sexual}

O conceito de moral sexual, inobstante a lei tenha sempre buscado justificar a interferência jurídico-penal nessa seara, tampouco consegue escapar do caráter de vagueza e imprecisão. Afinal, os "bons costumes" não podem ser entendidos sem se levar em

palavras. Não há qualquer intenção de chancelar o uso da expressão "menor" com caráter pejorativo, como se fosse equivalente a "moleque" ou "marginal", até porque quase sempre se referirá a esse grupo especial de pessoas na condição de vítimas, e não de autores de ato infracional equivalente a infração penal. De qualquer forma, O autor sabe que há orientação corrente, mormente após a promulgação da Constituição Federal de 1988 e da Lei 8.069/90 (ECA), que não se deve usar "menor" para fazer referência a crianças e adolescentes. Com efeito, segundo cartilhas destinadas a órgãos de imprensa, ao levantar a pergunta sobre quais seriam os termos mais apropriados para se referir a crianças e adolescentes quando se tem em vista a preservação de seus direitos, fixouse a seguinte orientação: "A mídia desempenha um papel importante na transmissão de informações corretas, que difundidas na sociedade podem colaborar para modificar mentalidades e pontos de vista. Por isso é importante que, ao redigir uma matéria, repórteres, editores e demais profissionais da mídia procurem adotar uma terminologia alinhada com os paradigmas preconizados pelas normas de direito internacional e nacional. 1 . Criança, menina, menino, garota, garoto, adolescente, rapaz, moça, jovem, ao invés de menor, moleque e outros. Isso porque o termo 'menor' reproduz o conceito de incapacidade na infância, sendo estigmatizante e discriminatório - e remete ao extinto Código de Menores." (Cf. informações extraídas da web page da ANDI, organização civil que articula ações inovadoras em mídia para o desenvolvimento, disponível em http://www.andi.org.br/faq/quais-sao-os-termos-mais-apropriados-para-se-referir-a-criancas-e-adolescentesquando-se-tem-em-, consultada em 18 de dezembro de 2012). 
consideração o conjunto de interesses, o caldo de cultura em determinado momento histórico, como a consciência ética de um povo.

Por isso, a tentativa de buscar distinguir o bem do mal, o honesto do desonesto, o admissível do intolerável, nessa área, esbarra em questões afeitas ao arcabouço de valores sociais que, como se sabe, não é estático, ao contrário, apresenta um dinamismo bastante intenso.

Nesse contexto, é preciso atentar à verdadeira evolução ocorrida, no decorrer nas eras, quanto ao conceito e ao alcance daquilo que se poderia chamar de moral sexual. ${ }^{37}$ Para tanto, inevitável voltar o olhar para o Direito Romano (tomado como o primeiro grande marco do exame evolutivo do tema), quando, ao menos no que interessa ao objeto desse estudo, começa a surgir aquilo que atualmente é conhecido como "pudor público" atinente aos costumes sexuais.

Com efeito, vale observar, àquela época, a predominância de uma concepção individualista, sendo notável a preocupação do sistema de leis romano quanto à tutela da pureza dos costumes daqueles submetidos ao poder paterno ou marital. ${ }^{38}$ Aparecem, então, por exemplo, os delitos de fornicação, sodomia, o estupro de mulher virgem ou viúva e o bestialismo.

Curioso verificar que tal classe de delitos sempre buscava a manutenção da pureza da família, que sofria clara interferência da chamada moral doméstica, com patente abrangência da figura masculina sobre os demais integrantes da casa. Segundo o senso comum, o objeto de ofensa nesse tipo de delito nunca era a própria mulher vítima da violação sexual, senão o seu marido ou mesmo seu pai (no caso de mulher solteira, por óbvio). ${ }^{39}$

\footnotetext{
${ }^{37}$ Nessa análise, serão levados em conta os critérios evolutivos trazidos por JORGE DE FIGUEIREDO DIAS, no texto Dos crimes contra Liberdade e Autodeterminação sexual. Em: DIAS, Jorge de Figueiredo (org.).

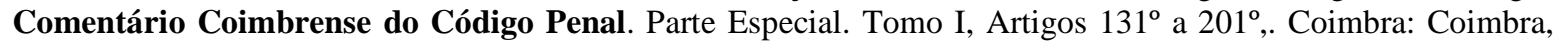
1999, p. 441-443.

${ }^{38}$ Importante lembrar que esse era o fundamento da família romana, havendo inegável influência religiosa nas relações privadas e parentais, sempre com a ascendência do pater familias sobre os filhos e a esposa.

${ }^{39}$ De outra banda, o que poderia configurar um contrassenso, a moral sexual reinante à época condenava práticas bigâmicas ou adúlteras. DIX SILVA, Tadeu..., ob. cit., p. 51.
} 
Mais adiante, seguindo cronologicamente, surge a confusão entre moral e pecado, típica dos ordenamentos jurídicos canônicos. Segundo a ideologia reinante na Idade Média, como ocorria em outras esferas, a sanção corporal quanto aos comportamentos sexuais estava sempre ligada, de forma indissociável à noção religiosa de ofensa aos mandamentos divinos, sendo aplicável o brocardo latino punitur quia paccatum est.

Aqui já aparece a perseguição, assumida pelo Estado sob fortíssima influência da religião cristã, a toda atividade tida como contrária ao pudor, ou seja, ao sentimento de recato, de retidão moral, surgindo a denominação de crimes morais. Busca-se proteger, a qualquer custo, a integridade das relações matrimonias, com a demonização de comportamentos ofensivos ao "laço sagrado" da instituição do casamento. Moral religiosa e sistema jurídicopenal sobrepõem-se sem qualquer peio.

O terceiro marco histórico no âmbito da moral sexual coletiva sobreveio com o Iluminismo do século XVIII, com inegável influência dos pensamentos liberais em diversas áreas do conhecimento, inclusive do Direito Penal sexual. A lei penal, então, procura conciliar as noções de crime sexual com a liberdade individual de cada um, sendo um embrião do conceito de "liberdade sexual", posteriormente integrado aos ordenamentos jurídicos no mundo ocidental, residindo aí sua importância ao tema em debate.

Já o quarto aspecto demarcatório, no campo do direito penal sexual, contrapõe-se aos avanços liberais iluministas, por conta do surgimento da filosofia idealista, no início do século XIX, alargando-se a criminalização de comportamentos alçados à condição de desonestos ou impudicos, sempre que estiver em jogo os denominados bons costumes.

Por fim, o quinto marco evolutivo sobreveio com a revolução no campo da cultura e dos costumes verificada nas décadas de 1960 e 1970, marcada por drásticas e notórias mudanças comportamentais - v.g., a contracultura, o movimento hippie, o desenvolvimento científico/tecnológico, o surgimento do feminismo e a liberação dos costumes sexuais - tanto na Europa como nos Estados Unidos. 
Com isso, tem lugar uma radical modificação de paradigmas, não sendo estranho falar em um tipo de nova era no contexto da sexualidade, devido, entre outras novidades liberalizantes, ao surgimento da pílula anticoncepcional feminina, atrelado à ideia de "amor livre" preconizada pelos jovens da época. Com isso, houve um natural fortalecimento do conceito de tolerância, ao menos na área sexual.

O exame de RENATO SILVEIRA dedicado ao tema da tolerância no âmbito do direito penal resume bem a função do pensamento tolerante em um Estado laico, já que tal princípio deve servir como limite à atividade legiferante nessa matéria, evitando-se o irregular uso da ameaça penal sobre algumas condutas. ${ }^{40}$

Consoante seu raciocínio, a ojeriza a determinadas práticas ou gostos de cunho sexual -assumido um viés moralista ou religioso - não pode servir de fundamento à incriminação dessas condutas, visto que o mundo hodierno não mais pode suportar imposições estranhas à liberdade e à dignidade do homem como fatores de criminalização. "Somando-se as bases da ultima ratio, da supremacia da liberdade e da tolerância, algumas conclusões podem ser tidas para o novo Direito Penal sexual.". E arremata que "é precisamente nessa tolerância que se devem escudar, por fim, as pretensões de criminalização sexual". 41

Outro corolário dessa mudança comportamental tem a ver com o surgimento de movimentos sociais de valorização das diferenças tanto de gênero quanto de orientação sexual, com o fortalecimento do direito dos homossexuais em diversas áreas, por exemplo. Tudo isso leva à esperada tolerância no âmbito de uma sociedade pluralista, de modo que esses vetores de diversidade sexual observados nos países liberais devem influenciar o legislador penal nessa seara, sendo de rigor a descriminalização de práticas homossexuais entre adultos.

\footnotetext{
${ }^{40}$ O ensaísta italiano NORBERTO BOBBIO, em obra dedicada ao estudo da Ética e da Moral, deixou assentado que "o único princípio que se pode considerar propriamente laico é o da tolerância, quer dizer, o princípio que constata a multiplicidade dos universos morais e disso extrai a consequência de que é necessária uma pacífica convivência entre eles. Desse ponto de vista, não tenho qualquer receio em afirmar que o pensamento laico é uma expressão essencial do mundo moderno e um efeito do processo de secularização, no qual as próprias Igrejas se reconheceram”. Ob. cit., p. 198.

${ }^{41}$ SILVEIRA, Renato..., Crimes sexuais..., p. 184.
} 
Ainda sobre o tema homossexualidade, convém destacar o pensamento de SILVIA MORICI, que vislumbrou o caráter pendular do modo de tratamento jurídico-penal dessa modalidade comportamental no decorrer dos tempos para sinalizar com a necessidade de enxergar o assunto sob a óptica da tolerância a fim de evitar a penalização de condutas nãoatentatórias aos interesses protegidos pela liberdade sexual.

Com efeito, segundo suas palavras, “uma rápida revisão na História (...) mostra que a homossexualidade, passando de um rito de iniciação para os jovens da Grécia antiga, uma prática aceite no mundo latino, a um pecado, uma 'abominação', na Idade Média, para depois ocupar um espaço entre as enfermidades, e já na era contemporânea, especificamente, dentro da psicopatologia." Mais adiante, em uma frase que resume o enfoque ideal acerca do tema, trazendo à baila o imperioso respeito às diferenças, conclui que "a tolerância social de uma cultura será dada pela relação entre a organização social particular de cada um e a moral sexual imperante da época". 42

Ademais, é assente a opinião pela qual o princípio da tolerância deve servir de guia ao legislador no momento de se erigir determinadas condutas como ilícitos penais, afinal não seria de bom alvitre que as concepções de grupos restritos se sobrevalessem, de forma absoluta, aos comportamentos indesejáveis de poucos. ${ }^{43}$

A respeito dos critérios de tolerância a serem seguidos pelo elaborador da lei penal, RENATO SILVEIRA também destaca a imperiosa prudência do legislador, ao sopesar os diversos vieses da sociedade pluralista, diante da constante mutabilidade e das novas perspectivas nesse campo que a realidade nos impõe. ${ }^{44}$

\footnotetext{
${ }^{42}$ MORICI, Silvia. Homossexualidade: um lugar na história da intolerância social, um lugar na clínica. In GRAÑA, Roberto B. (org.), Homossexualidade. Formulações psicanalíticas atuais, Porto Alegre: ARTMED, 1998, p. 147-148 (destaque meu).

${ }^{43}$ Afinal, como afirma FAGGIONI, "a tolerância é um requisito da prudência por permitir, de um lado, a obtenção da verdade provável e, doutro, por diminuir a tensão que pode levar à ruptura do equilíbrio social.” Ob. cit., p. 96. É importante repisar que o autor dessa dissertação de forma alguma considera a homossexualidade algo indesejado ou imoral. Ao revés, cada pessoa tem o direito de expressar sua sexualidade da maneira que melhor lhe aprouver, seguindo seus desejos e buscando a autorrealização. O problema é que nem sempre a sociedade "aceitou" tais comportamentos, justamente por faltar o critério da tolerância no julgamento ao comportamento alheio.

${ }^{44} \mathrm{O}$ questionamento trazido à baila pelo mencionado autor, nesse quadro, seria o de se verificar a legitimidade de o legislador impor, unilateralmente, limites à autorrealização sexual que contrariem certos grupos ou ideologias
} 
Assim, algumas ações antes abarcadas pelo espectro de incidência do Direito Penal tradicional, sob o prisma contemporâneo, merecem passar ao largo da previsão legal, tendo em conta a autodeterminação e a liberdades sexuais no contexto atual.

Os conceitos ético-sociais, em relação à sexualidade, progridem no decorrer dos tempos com velocidade ímpar, de sociedade para sociedade, não havendo espaço para dogmas ou ideias perenes ou estanques. Enfim, conforme já destacado, os hábitos e costumes de dada cultura não podem ser avaliados como uma regra imutável ou mesmo uma panaceia a ser buscada e aplicada de maneira indiscriminada pelo intérprete da norma penal, sob pena de indevido engessamento do sistema em matéria tão sensível a inovações.

Afinal, tendo em mente a complexa conformação do tecido social, na qual os diversos interesses estão em jogo, o Estado deve objetivar (e fomentar) a convivência e a confrontação dos distintos modos de entender e viver a existência humana, adquirindo a tolerância papel preponderante, cujo conteúdo deve pautar o direito penal sexual.

Diante desse novo contexto social e cultural, a vida sexual dos cidadãos, e a forma como o Estado a disciplina em termos penais também sofreu imensa alteração, à medida que, nesse diapasão, carece de sentido falar em criminalização de condutas consideradas imorais.

\subsubsection{Moral sexual e princípio da alteridade}

Ao lado da evolução sociocultural e dos critérios de política criminal aplicados ao âmbito da sexualidade (principalmente os vetores liberdade e tolerância, conforme desenvolvido até aqui), surge outro importante paradigma para a análise da moralidade sexual,

(geralmente dominantes), ainda que haja, por exemplo, agressões físicas decorrentes de práticas sadomasoquistas. Segundo sua conclusão, "a resposta, indiscutivelmente, é que não cabe à norma positivada decidir os destinos particulares do indivíduo de per se”. A negação das teses tradicionais do bem jurídico-penal sexual, segundo os costumes, a honestidade, o pudor, a moral ou seus conteúdos morais, leva a tal interpretação. 
consistente no chamado princípio da alteridade, pelo qual é preciso identificar as diferenças com a visão de mundo do outro, respeitando sua posição ideológica.

A imposição de padrões de comportamento considerados "normais" a todos os cidadãos, inclusive com o uso da violência estatal por meio dos órgãos de persecução penal, em detrimento de condutas "diferenciadas" nesta esfera pode levar à ofensa das acepções ético-morais que terceiros (minoria) poderiam ter. ${ }^{45}$

Esse princípio está atrelado à ideia de liberdade democrática, na qual o direito de livre pensamento de grupos minoritários há de ser assegurado justamente para a construção de uma sociedade plural, característica típica de regimes constitucionais do mundo ocidental. Afinal, de acordo com DIX SILVA, "a partir da existência da alteridade, do diferente, do outro, é que se pode construir uma identidade. Sem o outro, sem a alteridade, não existimos como indivíduos." 46

A ideia de liberdade - civil e política, constante de qualquer regime democrático - tem assento no exato momento em que "a liberdade reclamada pela democracia é aquela para todos, e não apenas para alguns, o que implica o estabelecimento de uma forma de igualdade entre os homens. Inversamente, todo o progresso para a igualdade - como supressão de determinados privilégios - é sentido por aqueles que estão excluídos como uma libertação". ${ }^{47}$

A estreita relação entre alteridade e dignidade da pessoa humana ${ }^{48}$ é evidente, na medida em que o reconhecimento e a tolerância à opinião alheia, inclusive da minoria, deve

\footnotetext{
${ }^{45}$ TADEU ANTÔNIO DIX DA SILVA invoca o postulado da alteridade como base imprescindível da análise sobre o alcance e os limites do que pode ser enquadrado sob o rótulo de "moral sexual". O autor, inclusive, explica que tal princípio advém da "ética da alteridade", citando diversos defensores dessa corrente ( $v . g$. HABERMAS, LÉVINAS, entre outros) e decorre da própria definição de "dignidade da pessoa humana", podendo ser resumido como a necessidade de se assegurar "o respeito ao outro e não permite qualquer violação que esse respeito devido ao semelhante possa eventualmente vir a sofrer”. Crimes sexuais..., ob. cit., p. 63.

${ }^{46}$ DIX SILVA, ob. cit., p. 65.

${ }^{47}$ DENNY, Ercílio A. Interpretar e Agir. Piracicaba: Opinião, 2002.

${ }^{48}$ Claro que, nessa ordem de ideias, devemos encarar a dignidade da pessoa humana no seu sentido material, efetivo, e não apenas formal, decorrente das normas programáticas constantes do texto constitucional. Tal princípio deve servir como um norte a orientar o legislador quando da elaboração do tipo penal, de modo que se o parlamentar eleger qualquer tipo de discriminação desprovida de conteúdo teleológico nesta diferenciação, fica
} 
assentar-se sobre sólidas premissas de convivência pacífica entre os cidadãos, genericamente considerados.

Daí porque, ao tentar erigir a moral sexual coletiva como diretriz para a confecção de figuras delitivas nessa área apresenta enorme risco de se instrumentalizar o Direito Penal, em seu sentido ideológico, aproximando-se muito mais do arbítrio do que do moderno Estado de Direito calcado no resguardo do caráter pluralista da sociedade.

Nessa linha, e adentrando mais especificamente no tema da sexualidade humana, a não-observância ao princípio da alteridade pode levar à inaceitável intolerância em relação a indivíduos que possuam hábitos sexuais heterodoxos, diferentes, gerando uma classe anômala de pessoas excluídas do espectro da moral sexual. ${ }^{49}$

Ou seja, deve-se trabalhar com a ideia de que o respeito a cada um sempre há de alcançar a figura do outro, estando ambos em pé de igualdade em termos de fruição de direitos e observância de deveres no campo sexual, mesmo que o diferente possa parecer estranho para os demais. Em outras palavras, a aceitação de diferentes padrões de opção sexual, sejam elas quais forem, desde que observadas certas $\operatorname{premissas}^{50}$, é medida que se impõe, com o escopo de se rechaçar a taxação de dadas condutas como imorais ou desviantes apenas por causa dos standarts impostos pela maioria nessa matéria.

clara a violação das balizas de sustentar da equidade, um dos traços marcantes, por exemplo, da República brasileira. DIX SILVA, Tadeu..., ob. cit., p. 67.

${ }^{49}$ JOSÉ MOURAZ LOPES utiliza o adjetivo "multifacetado" para se referir à sexualidade, o que se encaixa com o quanto afirmado até aqui sobre o princípio da alteridade como vetor a orientar o intérprete da lei penal nessa seara. Consoante seu entendimento, "o comportamento sexual é hoje visto e entendido como um fenômeno multifacetado, sendo admissíveis condutas que, ainda há bem pouco tempo, se entendiam como desviantes - caso da homossexualidade e, mais recentemente, a bissexualidade." LOPES, José Mouraz. Os crimes contra a liberdade e autodeterminação sexual no Código Penal. 4. a ed. Coimbra: Coimbra Editora, 2008, p. 17.

${ }^{50}$ Aqui convém um alerta para a melhor compreensão da relevância desse postulado ao objeto de nosso trabalho: a alteridade terá importância sempre que se trate de relações sexuais entre pessoas adultas, respeitado o consentimento válido dos envolvidos (autodeterminação sexual) e realizadas no âmbito privativo ou particular. Claro que quando se fala em sexualidade de crianças e adolescentes há uma mudança de paradigma, com o surgimento de outro sistema de valores, tais como o direito ao livre desenvolvimento sexual dos jovens, que pode ser tido como limite à dignidade humana do abusador ou do agente pedófilo, o que será mais bem delineado em sede própria. De qualquer forma, o princípio da alteridade deve ser observado justamente para evitar a estigmatização desse grupo peculiar de pessoas que, no mais das vezes, sofrem por causa de seus impulsos sexuais heterodoxos. 
A Moral deve ser encarada como uma base fundamental sobre a qual repousa o espectro maior do Direito Penal. As lições e os mandamentos de cunho jurídico podem (e, às vezes, é até saudável que assim o seja) fazer referência a critérios éticos ou morais. Entretanto, não é conveniente que sejam totalmente dependentes das diretrizes morais.

A confusão entre Direito e Moral, típica dos governos autocráticos, cujos vetores reinantes refletem na sobreposição entre esta e o poder político, não merece guarida em tempos atuais, uma vez que a mistura entre os conceitos acaba, inevitavelmente, instrumentalizando a norma jurídica em efeitos meramente moralizantes. Em qualquer Democracia moderna, isso é inconcebível.

Por tudo isso que a relevância da Moral como único imperativo absoluto para a criação, elaboração e aplicação de normas jurídicas no ramo dos crimes sexuais, com gritante caráter coercitivo e repressivo, não sobrevive aos ditames constitucionais. Neste aspecto, os paradigmas são outros, como se verá mais adiante: deve-se tutelar liberdades, e não impor sanções aos cidadãos por conta do eventual desvio aos padrões dominantes.

Seguindo no mesmo raciocínio, convém dizer que a imoralidade ou mesmo a contrariedade à ética atribuídas a dada conduta, a rigor, não poderiam autorizar a interferência estatal mediante a imposição de sanção criminal.

Segundo CLAUS ROXIN, se os pressupostos rígidos de uma convivência pacífica e livre na sociedade não forem claramente afrontados (lesionados ou ao menos ameaçados de lesão), a mera reprovabilidade de um ato humano está fora da alçada do Direito Penal, devendo ser tratado em outros âmbitos. ${ }^{51}$

Essa, aliás, foi a tônica das discussões que antecederam a reforma alemã do chamado Direito Penal Sexual, em 1973, que teve como escopo restringir a tutela penal a dois bens despidos de qualquer ranço moralista, como a proteção do interesse de crianças e adolescentes

\footnotetext{
${ }^{51}$ ROXIN, Claus. Que comportamentos pode o Estado proibir sob ameaça de pena? Sobre a legitimação das proibições penais, em Estudos de Direito Penal. 2. ${ }^{a}$ ed., Trad. Luís GrECo. Rio de Janeiro: Renovar, 2008, p. 33.
} 
(entendidos como incapazes, já que jovens em formação) e da autodeterminação sexual do cidadão.

Nesse momento, cabe uma breve digressão sobre o caso alemão, que configurou importante modelo de reforma aos demais ordenamentos jurídicos nos anos subsequentes, inclusive o brasileiro. Ou seja, para ter em conta a importância da mudança de paradigmas será necessário deitar o olhar para as diversas peculiaridades das discussões efetuadas no âmbito doutrinário e jurisprudencial na Alemanha, que acabaram por redefinir a estrutura repressiva no âmbito penal sexual.

A visão extremamente conservadora constante do texto do Código Penal alemão de 1871 foi objeto do Projeto Governamental de 1962, cujo teor procurava, não só a manutenção, como também (e principalmente) a ampliação da repressão penal a certos comportamentos no campo das relações sexuais, tudo em nome de uma proteção à moral então vigente na sociedade germânica.

Tendo em vista os objetivos do referido projeto de lei, a ideia seria manter intacto o capítulo relativo aos "crimes contra a honestidade" sexual, permanecendo como práticas delituosas, por exemplo, a homossexualidade entre adultos, a pornografia, a desmoralização, entre outros comportamentos. De outro lado, buscava-se a incriminação de novas classes de condutas, como a realização de strip-tease, permitindo ao Estado lançar mão da intervenção penal contra representações desonestas em revistas teatrais e cabarés. ${ }^{52}$

Os idealizadores do Projeto de Lei alemão assentavam a opinião de alargamento do espectro de incidência de tais normas a toda e qualquer conduta desviante daqueles estandartes comuns no meio social, no raciocínio de que "a pureza e a saúde da vida sexual é um pressuposto extraordinariamente importante para a existência do povo e para a manutenção da ordem natural da vida". ${ }^{53}$ Trata-se, como se vê, de posição bastante conservadora, já que a definição do que seria a pureza da vida sexual estaria atrelada àqueles critérios aceitáveis pela

\footnotetext{
${ }^{52}$ DIX SILVA, Tadeu..., ob. cit., p. 58.

${ }^{53}$ BAUER, Fritz. El derecho penal sexual en la actualidad. Em: BAUER, Fritz. Sexualidad y Crimen. Madri: Reus, 1969, p. 407-408. Apud SILVA, Tadeu..., ob. cit., p. 58.
} 
ética sexual coletiva - calcados em contexto claramente moralizante, não havendo qualquer espaço para a proteção do direito de cada qual proceder segundo seus próprios desejos na esfera individual de sua sexualidade.

Sensíveis ao perigo de descambar para a criminalização de condutas despidas de ofensividade ou lesividade, algo inadmissível em um Estado laico, diversos Professores e pensadores alemães opuseram-se frontalmente ao teor do Projeto Governamental, o que levou a um amplo debate nos meios acadêmicos e na sociedade civil.

Após a realização de um Congresso de Professores Alemães de Direito Penal, ocorrido em 1964, a contraposição às ideias draconianas do projeto oficial levou à formulação de um "Projeto Alternativo", dois anos mais tarde, assinado por nada menos do que catorze Professores estudiosos sobre a matéria.

O movimento acadêmico, imbuído de canalizar os anseios da sociedade alemã à época, fundamentou suas formulações em diversos textos jurídicos, filosóficos e sociológicos. ${ }^{54}$ Também foi dada especial atenção a dois famosos relatórios sobre Sexualidade ("Relatório Kinsey"55, de 1948 e "Wolfdenden Report", de 1957), sobre os quais se assentaram sérios estudos sociológicos e antropológicos atinentes à sexualidade humana.

\footnotetext{
${ }^{54}$ Por todos, convém transcrever a linha de pensamento segundo a qual "o direito serve à moralidade, não para dar execução a seus preceitos, mas apenas garantindo o livre desenvolvimento da força que eles têm no interior de cada um". ANDRADE, Manuel da Costa. Consentimento e Acordo em Direito Penal. Coimbra: 2004, p. 389 , nota 77

${ }^{55}$ A propósito, o "Relatório Kinsey" representou verdadeiro divisor de águas no debate sobre o comportamento sexual dos norte-americanos, principalmente no sentido de se derrubar diversos tabus relacionados, por exemplo, à masturbação e ao homossexualismo. A relevância do trabalho desse zoólogo norte-americano ALFRED KINSEY, além da ampla base científica que dá guarida a tal Relatório, situa-se no ineditismo de expor ao grande público uma visão despudorada, despida de preconceitos, a respeito do proceder sexual, mormente o masculino, naquele país. Por isso, tais estudos foram amplamente utilizados como base para a futura "revolução sexual" que se avizinhava. Isso sem falar nos rigorosos critérios empíricos empregados em suas pesquisas, o que demonstra a seriedade de sua atuação científica. Segundo a Wikipédia, "A publicação do primeiro volume do famoso relatório sobre a sexualidade masculina (Sexual Behavior in the Human Male), em 1948, deu origem a uma enorme polêmica nos Estados Unidos. O livro foi um dos mais vendidos naquele ano. Rapidamente, Kinsey se transformou numa celebridade, considerado até hoje como uma das personalidades mais polêmicas do século XX. Foi capa dos principais jornais e revistas do país. (...) A controvérsia que daí resultou foi inevitável, pois certos dados chocavam a estrutura clássica da família americana no final da década de 1940 e início da década de 1950. A América acabava de descobrir que, segundo os estudos de Kinsey, 92\% dos seus homens e $62 \%$ das suas mulheres se masturbava. E que $37 \%$ dos homens e $13 \%$ das mulheres já tinham tido uma relação homossexual que lhes tinha proporcionado um orgasmo. Neste caso, os fatos foram noticiados pela imprensa sensacionalista como uma verdadeira bomba". (disponível em:
} 
O Supremo Tribunal alemão, influenciado pela corrente liberal advinda do mundo acadêmico, bebeu da mesma fonte doutrinária liberal ao afastar o caráter obsceno de uma publicação literária denominada "Memórias de Funny Hill”, pontuando que, por definitivo, não era papel do Estado contemporâneo, laico e constitucional, exigir determinados comportamentos sexuais segundo uma linha-padrão de "normalidade". A interferência estatal deveria ficar restrita aos casos de ofensa ou perturbações graves, delegando ao livre arbítrio dos indivíduos a realização de suas vontades no campo sexual.

Ademais, o tema da reforma penal sexual na Alemanha apresenta extrema utilidade à análise da influência da denominada moral social no Direito Penal, uma vez que ainda hoje algumas condutas como exibicionismo $(\S 183)^{56}$, o voyeurismo, a provocação de escândalo público (§ 183-a), ou mesmo o incesto - entendido como a livre prática de relação sexual consentida entre adultos $(\$ 173)^{57}$ - contêm típico caráter moralista, pretendendo-se proteger uma moral social incondizente com os ditames democráticos do Estado Constitucional de Direito. $^{58}$

http://pt.wikipedia.org/wiki/Alfred_Kinsey\#O_Relat.C3.B3rio_Kinsey). O caráter revolucionário de sua obra foi tamanho que uma parte de sua trajetória foi levada ao cinema no filme "Relatório Kinsey - Vamos falar de sexo?", lançado em 2005, tendo o famoso ator hollywoodiano LIAM NEESON no papel do polêmico cientista. A sua relevância para as pesquisas científicas no campo da sexualidade serviu de base para interessante expressão cunhada em reportagem do periódico online 'veja.com': "é fato que o professor de gravata-borboleta era uma personalidade das mais coloridas, e que seu comportamento no campus seria inaceitável pelos padrões acadêmicos de hoje. Mas uma coisa não se pode negar: foi ele quem tirou de vez o sexo do armário." ("O cientista que só pensava naquilo", artigo de Isabela Nobocov, disponível em http://veja.abril.com.br/201004/p 094.html, acessado em 11 de setembro de 2012, destaque meu).

${ }^{56}$ Equivalente à figura do ato obsceno prevista no artigo 233 do Código Penal brasileiro (esta será abordada mais adiante).

${ }^{57}$ Apenas um adendo: conforme já adiantado na introdução, a Corte Constitucional alemã teve a oportunidade de enfrentar o assunto relativo à (in)constitucionalidade dessa figura penal (incesto). No entanto, mesmo com o nítido caráter moralista, desprovido de qualquer apoio em questões jurídico-penais, de tal incriminação, o tipo ainda subsiste. Diante dessa situação, LUÍS GRECO ressalta o equívoco da decisão alemã à medida que "o Tribunal Constitucional Alemão acabou atribuindo ao direito penal a tarefa de manutenção e fortalecimento de convicções morais, Esta é uma tarefa em princípio estranha à tradição liberal, pois os esforços de vários penalistas desde Feuerbach, passando pela Escola Moderna até o Projeto alternativo do Código Penal alemão se dirigia no sentido de separar Direito e Moral." Tem futuro a teoria..., ob. cit., p. 172.

${ }^{58}$ Não por outra razão GÜNTER STRATENWERTH, utilizando-se de interessante expressão, pontua que "na verdade, tanto o escândalo publico quanto o caráter ofensivo das ações exibicionistas são fundados na lesão de um tabu cultural. (...) O argumento decisivo contra a punibilidade, p.ex., do homossexualismo simples, não é a falta de qualquer bem jurídico merecedor de proteção, e sim de qualquer referência social do comportamento sexual de adultos privado e consentido." Sobre o conceito de 'bem jurídico', in $\mathbf{O}$ bem jurídico como limitação do poder estatal de incriminar? GRECO, Luís; TÓRTIMA, Fernanda Lara (org.), Rio de Janeiro: Lumen Juris, p. 113. 
A proteção de sentimentos desagradáveis decorrentes de alguma conduta, mediante a tutela estatal com a incidência do controle penal, aparece como sendo inconcebível. Afinal, o fato de muitas pessoas ficarem enojadas quanto a aspectos de dado comportamento humano que atinjam a sensibilidade ou a representação daquilo considerado integrante de uma "vida correta" não pode ter o condão de fundamentar a incidência da sanção criminal. ${ }^{59}$

A doutrina utiliza-se de uma expressão para estabelecer a separação entre Direito e Moral: o chamado "limite interno" segundo o qual tanto o penal quanto o Direito em geral deveria abster-se apenas a regular condutas externas (ou exteriorizadas) de uma pessoa, já que apenas com ela que ultrapassa o limite de liberdade dos demais.

Isso porque a teoria da legalidade/moralidade constitui um princípio pelo qual o Direito “deberá conformarse con el cumplimiento externo-legal de sus disposiciones. Si estas reglas se cumplen o no, ya sea por un sentido del deber o respecto hacia la libertad del otro, (...) es algo que solamente interesa a la moral." 60

Como se vê, a autonomia da vida privada, tema a ser abordado no próximo capítulo, acaba aparecendo como um verdadeiro "limite interno" para a possibilidade de incriminar condutas com base em preceitos morais. A ação humana tida como bizarra, o ato estranho, asqueroso, os pensamentos maléficos - tudo de conteúdo altamente contrário à ética - não podem levar à interferência do Direito nas escolhas do indivíduo.

\footnotetext{
${ }^{59}$ Consoante o raciocínio de Roxin, o eventual desconforto que uma conduta provoca a terceiros não pode ser evitado com a ajuda do Direito Penal "porque una sociedad libre se basa en el presupuesto de que cada uno puede hacer y dejar hacer lo que él quiera en tanto no afecte a la esfera jurídica del otro." Dependencia e independencia del Derecho Penal con respecto a la política, la filosofía, la moral y la religión. Em: Anuário de derecho penal y ciencias penales, tomo LIX, Madrid: Ministerio de Justicia, 2008, p. 19. É digno de nota que o mesmo autor alemão admite o controle dessas condutas por meio de outras instâncias estatais (direito civil ou administrativo). Porém, entendemos que, em alguns casos (atinentes à esfera absoluta da vida privada, como se desenvolverá mais adiante), sequer essas sanções seriam autorizáveis.

${ }^{60}$ KÜHL, Kristian. Derecho penal y moral. Criminalidad, evolución del derecho penal y crítica al derecho penal en la actualidad. ZAFFARONI, Eugenio Raúl e outros. Ciudad Autonoma de Buenos Aires: Del Puerto, 2009, p. 230.
} 
$\mathrm{Na}$ mesma direção apontam as inovações trazidas pela mudança na lei portuguesa (conforme Decreto-Lei n. ${ }^{\circ}$ 48/95), por exemplo, no tocante ao enquadramento jurídico-penal da exploração sexual de crianças, com referência expressa à autodeterminação sexual, deixando-se de lado a antiga visão de proteção aos interesses da comunidade, constante do Código Penal de 1982 (e, claro, de outros diplomas anteriores a este).

MARIA JOÃO ANTUNES comenta essa clara evolução do direito penal sexual no sentido de "deixar de ser um direito tutelar da 'honestidade', dos 'costumes', ou dos 'bons costumes' - e onde por isso caberia a punibilidade de práticas sexuais que, à luz dos 'sentimentos gerais de moralidade sexual', devessem ser consideradas 'desviadas', 'anormais' 'viciosas' ou 'contra a natureza': numa [sic] palavra 'imorais' (a homossexualidade e a prostituição incluídas) - para se tornar num [sic] direito tutelar (...) da liberdade e autodeterminação da pessoa na esfera sexual". ${ }^{61}$

Outrossim, importante dizer que a doutrina e as legislações avançaram bastante sobre a delimitação desses limites e interferências. Afinal de contas, há uma patente diferenciação entre as posições, digamos, mais tradicionais (ou conservadoras) e aquelas denominadas mais liberais (ou modernas) quanto à verificação da influência ético-moral nos assuntos jurídicopenais. ${ }^{62}$ Em suma, enquanto aquelas entendem imprescindível a tutela de interesses e valores éticos sociais e da "pureza" da vida sexual, a posição mais progressista e libertária entende necessário o afastamento entre Moral e Direito, sempre tendo em mente a preservação da autonomia do indivíduo de viver a sua vida sem interferências indevidas.

\footnotetext{
${ }^{61}$ Crimes contra menores: incriminação para além da liberdade e da autodeterminação sexual. Boletim da Faculdade de Direito, Coimbra, v. 81, p. 59, 2005. A propósito e já adiantando o objeto específico a ser tratado na presente monografia, a mesma autora, abordando os casos de pornografia infantil virtual, adverte que "alguns dos comportamentos aqui incriminados significam o regresso ao direito penal que punia a violação de normas de natureza estritamente moral. Referimo-nos, designadamente, a comportamentos que envolvem a utilização de material pornográfico, simulado ou manipulado de menor não existente e a aquisição e detenção de materiais pornográficos que envolvam menores" (ob. cit., p. 66, destaques meus).

${ }^{62}$ A opinião externada por JOSÉ MOURAZ LOPES, a respeito dos delitos sexuais no sistema português, cabe como uma luva ao quanto afirmado, visto que "em nenhum dos crimes contra a liberdade e contra a autodeterminação sexual (...) se encontra, agora, a mais leve referência a qualquer conceito de índole moral. (...) $\mathrm{O}$ direito penal tem de manter distâncias em relação aos programas de ética sexual, qualquer que seja a sua orientação. Despindo-se pela primeira vez o sexo das vestes morais que sempre carregou, importa agora não o deixar nu na praça pública." Ob. cit., p. 17.
} 
Nos dizeres de RENATO DE MELLO JORGE SILVEIRA, "que se justifique a influência cristã no Direito Penal. Que se justifique todo o conteúdo mítico da sexualidade. Que se justifique, enfim, toda a trama psicológica que torna difícil o trato desses assuntos. Ora, em tempo de hoje, nenhuma destas, ou de outras justificativas, imporiam aspectos morais a serem, pela lei penal, aplicados. Idos também, são os tempos em que poder-se-ia admitir a intromissão, na seara penalística, de aspectos tão volúveis quanto os morais."63

Já adiantando o raciocínio a ser desenvolvido na presente sede, talvez um claro indicativo da mudança de paradigmas, na área legislativa dos países ocidentais, da relação entre Direito e Moral na proteção penal no campo sexual, deu-se na alteração literal da própria lei. Descarta-se a noção de bons costumes, de pudor público, de "honestidade" - com nítido cunho moralizante -, abraçando-se novos vetores como dignidade sexual, autodeterminação e liberdade sexual.

Nesse passo, estabelecidas as discrepâncias e as semelhanças de objetos do que se considera afeito aos campos do Direito e da Moral, à luz da chamada moralidade sexual, avancemos em nosso raciocínio, na busca de parâmetros seguros - e condizentes com a ordem constitucional - de limites a essa interferência estatal, principalmente quando levados em conta os aspectos mais íntimos do cidadão.

\footnotetext{
${ }^{63}$ SILVEIRA, Renato de Mello Jorge. Por um novo direito penal sexual: a moral e a questão da honestidade. Revista Brasileira de Ciências Criminais, São Paulo, n 33, jan./mar. 2001, p. 153.
} 


\section{Capitulo 2 - A AUTONOMIA DO INDIVÍDUO. ESFERA NUCLEAR DE PRIVACIDADE INVIOLÁVEL}

Nesse capítulo, buscar-se-á abordar alguns critérios que, muito além das teorias do bem jurídico (ou mesmo dos limites constitucionais negativos ou positivos), poderão servir de base para um exame cuidadoso dos comportamentos humanos insuscetíveis de regulação pelo Estado.

Com isso, o posterior desenvolvimento do tema específico dos comportamentos relacionados à pornografia infantil está, de alguma forma, atrelado às considerações doutrinárias a respeito de alguns importantes conceitos, tais como: o liberalismo, a autonomia privada, as noções de privacidade/intimidade do indivíduo em face das interferências do poder constituído e o paternalismo - em suas mais diversas facetas.

O objetivo primordial desse capítulo está lastreado, após as digressões teóricas a respeito das liberdades individuais, na tentativa de se fazer um cotejo entre os assuntos relacionados à sexualidade humana e os critérios de autonomia que sejam possivelmente aplicáveis, juntamente com os chamados princípios clássicos do Direito Penal (ofensividade, lesividade, proteção de bens jurídicos) aos tipos relativos à pornografia infantil.

Uma vez delineada a esfera autônoma inabalável como limite à intervenção estatal, poder-se-á analisar a conveniência de, na vã tentativa de "consertar" o comportamento sexual ou mesmo evitar a ofensa concreta aos direitos da criança e do adolescente, estabelecer sanções penais a alguém que porte material pornográfico infantil simulado, por exemplo.

Feitos esses breves esclarecimentos introdutórios, passemos à apresentação resumida dos conceitos relativos a esse âmbito privado como base para se chegar, mais adiante, à 
análise de seus reflexos com relação à legislação relativa à proteção da criança e do adolescente.

\subsection{Notas introdutórias: o liberalismo}

Em primeiro lugar, impossível começar a falar sobre esfera inviolável absoluta do indivíduo sem o estudo de alguns pensadores com relação à questão do liberalismo. $\mathrm{O}$ alcance do chamado liberalismo clássico, que aparece com especial destaque na obra On liberty, de JOHN STUART MILL ${ }^{64}$, um verdadeiro divisor de águas datado da metade do século XIX -, acaba sendo o ponto de partida de todos os demais objetos deste capítulo.

Muito embora, no decorrer do século XX, as ideias de MILL tenham ficado esquecidas, em razão do predomínio de movimentos autoritários e arbitrários (antiliberais) - como, por exemplo, o fascismo, o nazismo e as ditaduras comunistas - calha dizer que o mencionado texto, além do tremendo sucesso quando de sua publicação, vem sendo considerado a obra básica sobre o liberalismo.

A propósito, depois que se percebeu o enorme risco da instituição de Estados totalitários descambarem para práticas odiosas, como o genocídio e a perseguição a determinados grupos e minorias (não é ocioso lembrar a tragédia do Holocausto na II Guerra), houve uma real preocupação das democracias liberais do mundo ocidental para com o ideário liberal proposto pelo clássico autor inglês. ${ }^{65}$

\footnotetext{
${ }^{64}$ MILL, John Stuart, Sobre a liberdade, Tradução de Ari R. Tank Brito, São Paulo: Hedra, 2010.

${ }^{65}$ Daí a impressionante atualidade - aliás, traço típico de atemporalidade de qualquer trabalho rotulado como "clássico" - da mencionada obra, uma vez que os limites negativos de imposição de medidas coativas estatais continuam a permear as preocupações dos pensadores do Direito Penal contemporâneo. Justo por isso, em apresentação à obra constante de determinada reedição pela Editora Vozes, de 1991, CELSO LAFER esclarece as justificativas pelas quais esse livro merece a etiqueta de clássico: "a meu ver, este livro de Stuart Mill tem as virtudes de um clássico, posto que é (I) altamente representativo e esclarecedor da doutrina liberal do século XIX, especialmente na sua vertente inglesa; (II) vem suscitando até hoje, pela sua atualidade, distintas leituras, sendo o seu autor visto, ora como conservador, ora como antecipador da convergência progressista de liberalismo e socialismo; e (III) deu uma contribuição a uma sempre difícil teoria modelar da liberdade, que merece ser permanentemente ouvida e meditada." (cf. edição citada, p. 11, disponível em http://pt.scribd.com/doc/105613644/00171-Sobre-a-Liberdade).
} 
Com efeito, partindo-se da premissa de que todo governo ostenta, necessariamente, certa tendência inata ao abuso e à tirania, o eterno conflito entre autoridade e liberdade deve ser solucionado sempre tendo em mente a proteção dos indivíduos face aos desmandos do governante de plantão (leia-se: dos dirigentes políticos).

Aqui importa ressaltar que, mesmo na constância de um regime de governo pautado por uma democracia representativa, nada impede a eventual formação de uma "tirania social" da maioria, de modo que a vontade de correntes majoritárias de pensamento na sociedade pode desaguar na intromissão do Estado em assuntos próprios do indivíduo. É justamente isso que se busca evitar (ou, pelo menos, amenizar) com a elaboração de limites objetivos de atuação sobre os anseios estatais de controle social exercidos sobre o cidadão. ${ }^{66}$

Importante ressaltar, nesse particular, sem receio de errar, a superioridade da dignidade da pessoa humana como um bem superior à organização política, de modo que o argumento liberal (relativo aos direitos individuais) independe do viés democrático (concebido como uma “vontade geral”). Afinal, só assim pode entender como legítimo o poder estatal, uma vez que, em suma, a ordem democrática moderna pressupõe a ideia de todos vivermos seguros não apenas em face de ofensas privadas (proveniente da ação de outros cidadãos), senão (e principalmente) diante da força coercitiva estatal. ${ }^{67}$

Na busca de elementos integrantes da esfera inviolável, destaca-se o direito ao livre pensamento, ou à liberdade de expressão e opinião acerca dos assuntos da vida civilizada. Claro, pois como a sociedade é dinâmica, e todos os assuntos relativos aos valores e à moral

\footnotetext{
${ }^{66}$ MILL, John Stuart, ob. cit., p. 43.

${ }^{67}$ Nos dizeres de JOSÉ RAMÓN RECALDE, "Parece, en efecto, una convicción adquirida en la ética política actual la de que la legitimidad del poder no consiste, fundamentalmente, en la adecuada ordenación del Estado frente al individuo, sino en la limitación del Estado frente al individuo. La ideia de sistema democrático se aparta, por lo tanto, de lo que como tal podría entenderse en la democracia clásica de los griegos, e igualmente del modelo rousseauniano. (...) Podríamos, en suma, decir, que la libertad es la de vivir seguros, pero no sólo frente a la violencia privada, sino también frente a la fuerza del Estado, por mucho que ese Estado garantice la 'libertad para mandar'. No hay, por lo tanto, contradicción entre seguridad y libertad sino una extensión del concepto de seguridad en el marco de las libertades constitucionales. Un orden democrático moderno es, por lo tanto, un orden de garantías: frente a la violencia privada, frente al ejercicio autocrático del poder y frente al autoritarismo del mismo sistema de la mayoría.". La autonomía del individuo y la promoción de la vida buena. Eguzkilore: Cuaderno del Instituto Vasco de Criminología, San Sebastián, n. ${ }^{\circ} 5$ extraordinario, dez. 1992, p. 266.
} 
são mutáveis, é fundamental a salvaguarda, pelo Estado, do pleno exercício dessa garantia por parte dos integrantes do corpo social.

Desse modo, a mera circunstância de existir um senso comum de maneira alguma será considerada justificativa para impor a determinada pessoa comportamentos preestabelecidos, sob pena de se aniquilar um aspecto muito caro em uma sociedade democrática, qual seja, o livre arbítrio responsável. Os costumes consagrados pela maioria não podem servir de base para o condicionamento automático dos demais integrantes do pacto social. ${ }^{68}$

A relevância (ainda que possa parecer óbvia segundo uma lógica comum) desse raciocínio é de extrema relevância para o próprio desenvolvimento tecnológico e humano de uma sociedade. Realmente, os avanços em diversas áreas do conhecimento somente foram possíveis porque alguém pensou o assunto de uma forma inovadora ou arrojada. ${ }^{69}$

Talvez por isso, como destacado pelo Juiz de Direito em São Paulo LUIZ FERNANDO CARMAGO DE BARROS VIDAL, ao apresentar uma análise crítica das inovações ainda trazidas pela Lei 10.764/03 a alguns artigos do Estatuto da Criança e do Adolescente, relativos à pornografia infantil, não andou bem o legislador ao ampliar ao leque de abrangência da repressão penal (tipos abertos) sem levar em conta o caráter artístico e transgressor em algumas obras (p. ex., no livro "Lolita", de Vladimir Nabokov, ou na série televisiva "Presença de Anita"). ${ }^{70}$

Trazendo esses ensinamentos ao objeto do presente estudo, fica bastante clara a intenção por detrás da criminalização de condutas como a posse de pornografia infantil

\footnotetext{
${ }^{68}$ Nesse sentido, o mesmo MILL traça uma interessante comparação entre o exercício de preferências morais e mentais com o aprimoramento dos músculos do corpo humano: "aquele que faz algo só porque assim é o costume, não faz uma escolha. (...) O Mental e o moral, tal como os poderes dos músculos, são aprimorados apenas quando usados. As faculdades não são usadas quando se faz algo meramente por que outros o fazem do mesmo jeito." Ob. cit., p. 119.

${ }^{69}$ Digno de nota a menção ao horripilante contexto trazido por ALDOUS HuXLEY, em sua obra clássica "Admirável Mundo Novo", em que se faz um retrato pessimista e distópico de uma sociedade marcada por castas de seres condicionados desde a fase embrionária, tudo em nome da "segurança social". Sem as chamadas atitudes "transgressoras" fica impossível imaginar o desenvolvimento econômico, social e cultural de um povo.

${ }^{70}$ Conforme palestra proferida em grupo de estudos, em 2004, logo após aquela mudança legislativa. VIDAL, Luis Fernando Camargo de Barros. Crimes contra a criança e o adolescente: lei 10.764/2003. São Paulo: IBCCRIM - Instituto Brasileiro de Ciências Criminais, 2004. 3 v. (Curso de atualizações legislativas).
} 
simulada (virtual): sob a pecha de proteger a criança e o adolescente, o legislador prevê sanções graves à liberdade do indivíduo, na verdade, tão-somente porque é "chocante", "feio", "imoral", "de péssimo gosto" alguém portar esse tipo de material. É o Estado interferindo na vida privada do indivíduo, sem qualquer ofensa a interesses jurídicos delimitados. ${ }^{71}$

Há, ainda, outro conceito que serve de parâmetro para delinear o alcance do liberalismo no tocante a incriminações injustificadas de condutas: o paternalismo, isto é, a imposição forçada, por meio da elaboração de normas coercitivas, ao indivíduo de viver sua vida de uma dada maneira.

\subsection{O paternalismo jurídico-penal}

A título de definição, paternalismo, cuja origem é anglo-saxã (muito embora pudesse sugerir, em termos etimológicos, uma raiz latina), pode ser definido, no aspecto jurídico, como a administração paternal do Estado, voltada à regulação da vida social da mesma maneira como um pai faria com sua família. Seria, nesse sentido, a imposição da vontade do mais forte, pois ele saberia qual a melhor forma de proteger o mais fraco, o indefeso. ${ }^{72}$

Comportamento paternalista, então, seria a interferência na liberdade de conduta das pessoas, justificada por critérios relacionados à felicidade, ao bem-estar ou aos interesses individuais dos destinatários das normas, independentemente da vontade ou da personalidade destes.

\footnotetext{
${ }^{71}$ Esse raciocínio, por óbvio, será mais bem desenvolvido em capítulo próprio neste trabalho, mas a menção serve para traçar um paralelo entre o liberalismo e o objeto desta dissertação.

${ }^{72}$ MIGUEL REALE JÚNIOR traz, em artigo publicado na Revista Brasileira de Filosofia (ob. cit., p. 287) uma expressão bastante perspicaz e que resume bem o espírito paternalista: "Paternalismo orgânico: sei o que é bom para você".
} 
O paternalismo, então, é definido como a ingerência na liberdade de escolha de alguém, com ou sem coerção, para o próprio bem desta pessoa, contra os seus desejos. ${ }^{73} \mathrm{Ou}$ seja, parte-se da ideia de opinião pública dominante (no mais das vezes, com nítido cunho ético ou moralista) da classe política dirigente para impor determinado modo de ser a todo o corpo social.

A doutrina, com o escopo de contribuir para o esclarecimento do alcance do instituto, vem tratando do tema do paternalismo, nos seus mais diversos aspectos, inclusive com diferentes classificações, dependendo dos possíveis ângulos de análise do assunto. Fiquemos, neste momento, com um breve apanhado dos pontos mais relevantes ao foco de nosso estudo, e que serão úteis para a análise a ser desenvolvida mais adiante, no tocante aos reflexos das ideias paternalistas sobre a interferência do Direito Penal no âmbito da sexualidade dos menores.

Em primeiro lugar, segundo o raciocínio de RONALD DWORKIN, pode-se distinguir entre paternalismo puro ou impuro. O puro será aquele no qual existe a coincidência entre o grupo de indivíduos que sofre a restrição à sua liberdade da esfera privada e as pessoas para quem se busca o resultado benevolente. Já o paternalismo impuro impõe restrições a certo universo de indivíduos a fim de tentar proteger o bem-estar de terceiros. ${ }^{74} 75$

Há ainda outra interessante classificação dada por JOEL FEINBERG, no conjunto de estudos relativos aos limites morais do Direito Penal (Harm to self, v. 3), que merece

\footnotetext{
${ }^{73}$ JOÃO PAULO ORSINI MARTINELLI, em obra dedicada à análise do viés paternalista na legislação sobre entorpecentes, resume as características do conceito: “(1) a intervenção na liberdade de seleção de alguém; (2) quem interfere quer o bem da pessoa que sofreu a interferência; (3) aquele que interfere age contra a vontade do suposto beneficiado". Paternalismo na lei de drogas. Revista Liberdades, São Paulo, no 2, set./dez. 2009, p. 14.

${ }^{74}$ Convém destacar que MARTINELLI traz dois exemplos que esclarecem bem as diferenças: como hipótese de comportamento paternalista puro, seria a obrigatoriedade do uso de cinto de segurança na direção de veículo automotor (afinal, em caso de sinistro, apenas a incolumidade física e a vida dos próprios destinatários da norma seriam tuteladas), enquanto que exemplo de impuro seria a proibição de fabricação de cigarros às indústrias tabagistas, com a finalidade reflexa de salvaguardar a saúde de fumantes. Op cit., p. 15.

${ }^{75}$ Seguindo parâmetros parecidos, JOEL FEINBERG procura diferenciar paternalismo direto de indireto. Apesar da pequena diferença terminológica, as ideias predominantes, e que serão relevantes ao nosso objeto de estudo, repousam na diferenciação entre as hipóteses que abarcam apenas uma só parte (p. ex., proibição da autolesão, do uso de entorpecentes) e outros casos envolvendo duas partes (p. ex., a proibição da eutanásia, do homicídio a pedido de outrem etc.). ESTELLITA, HELOISA, Paternalismo, moralismo e direito penal: alguns crimes suspeitos em nosso direito positivo. Revista Brasileira de Filosofia, São Paulo, vol. LVI, fasc. 227, jul./set. 2007, p. 334.
} 
destaque: i) Paternalismo presumivelmente censurável, em que se abordam adultos como se crianças fossem, ao impor determinada condutas comissivas ou omissivas, e ii) paternalismo presumivelmente não censurável, que pretende tutelar pessoas "vulneráveis" (ou "incompetentes") de atitudes de terceiros quando não houver consentimento voluntário quanto aos riscos. ${ }^{76}$

O paternalismo presumivelmente censurável, por seu turno, pode ser subdivido em $i$ ) benevolent paternalism para definir o caráter benevolente, no sentido de "forçar" o cidadão a ter comportamentos virtuosos e consoantes com noções consagradas de "bem-estar" (ou estilo de vida "prudente"), vigentes no campo dos valores morais de um povo em determinado lugar e época, por meio da coação da força estatal. Exemplos interessantes seriam o de prever sanções para aquelas pessoas que ingerissem alimentos gordurosos, para os fumantes ou então, em último caso, obrigar os cidadãos a fazerem exercícios físicos regularmente. ${ }^{77}$ Ou então, em ii) non-benevolent paternalism, quando se procura respeitar o bem de outras partes, como, por exemplo, a imposição de restrições a professores ou, conforme já dito, a gerentes de empresas.

Apenas abrindo um parêntese, mesmo sem aprofundar na matéria teórica, fica relativamente fácil defender, no atual grau de desenvolvimento das democracias contemporâneas, que os critérios de paternalismo benevolente não se sustentam quando se leva em conta a esfera inviolável de cada um ser dono de seu próprio destino, abraçando o estilo de vida que lhe parece mais adequado para atingir a realização pessoal.

No máximo, ao Estado, como ente representativo dos anseios e das vontades das maiorias, caberia apontar, sem qualquer imposição forçada, os critérios mais razoáveis para o pleno bem-estar generalizado. Mas nunca por meio de interferências absolutas. ${ }^{78}$

\footnotetext{
${ }^{76}$ Ainda usando os critérios desenvolvidos por FEINBERG, também se pode falar em paternalismo rígido ou moderado, quando se examina o grau de "competência" do destinatário da restrição, de modo que o primeiro é exercido sobre pessoas que têm suficiente grau de discernimento para julgar o que é mais conveniente para sua vida e o segundo trata de pessoas que não possuem tal nível de exercer seus direitos de personalidade (os chamados vulneráveis).

${ }^{77}$ REALE JÚNIOR, Miguel. Ob. cit., p. 293.

${ }^{78}$ MARCO SEGRE traz esclarecedores comentários sobre o paternalismo no mundo ocidental que, segundo ele, "deve existir a separação dos poderes, a separação entre âmbitos privado e público, entre Estado e Igreja, como forma de respeitar a diferenciação do corpo social, necessária ao bom funcionamento das sociedades complexas
} 
A impertinência dessas posturas paternalistas em uma sociedade regida pelo respeito às liberdades individuais fica mais evidente quando se fala na utilização do Direito Penal como instrumento coercitivo que, como se sabe, deveria ficar relegado apenas para situações extremas. Afinal, ao usar leis de cunho penal, o poder político acaba sendo exercido, coercitivamente, sobre o comportamento do indivíduo, lançando mão do meio mais oneroso com a privação ou restrição de liberdade. Isso, por óbvio, é inadmissível. ${ }^{79}$

Por essas razões, não podem ser deixados de nota dois alertas importantes: de um lado, o risco de se descambar para o despotismo político e, de outro, a criticável criação de uma verdadeira "polícia moral", com o incremento - em nosso ver, injustificável e ilegítimo - de um Direito Penal que puna pensamentos maus.

Em outros termos, esse risco existe quando "a imposição da ação correta fundamentase na presunção absoluta de ser o cidadão um ser frágil e devidamente orientado. Esta imprescindibilidade de indicar a ação correta aos cidadãos infantilizados, quando se transforma na base de uma ação política, tem por consequência a instalação do despotismo."80

Diante disso, tendo em conta o atual grau de evolução dos direitos fundamentais nas legislações modernas - e sabendo-se dos tristes exemplos históricos de abuso de poder que levaram à instituição de governos totalitários e autoritários - o receio da má utilização dessas práticas paternalistas não pode ser ignorado.

Como se sabe, pensamentos (e atitudes, no campo exclusivo da autonomia) até podem levar à infelicidade ou à degradação intelectual (ou moral) do indivíduo, porém o seu bemestar nem de longe pode legitimar uma proibição sancionatória penal. Ninguém pode ser

onde vige de fato um pluralismo de interesses, de valores e crenças que precisam ser considerados nas suas 'diferenças'." Ob. cit., p. 21.

${ }^{79}$ Cf. MARTINELLI, João Paulo Orsini, ob. cit., p. 16.

${ }^{80}$ REALE JÚNIOR, Miguel, ob. cit., p. 292. 
punido por ter pensamentos ruins ou "inapropriados", afinal, "o Estado não pode forçar os cidadãos à felicidade". ${ }^{81}$

De qualquer forma, ao reconhecer a importância (e ao colocar em prática) a autonomia individual do cidadão - inclusive no que toca aos pensamentos da pessoa -, evita-se, sem sombra de dúvida, uma postura paternalista do Direito Penal. ${ }^{82}$

Fazendo-se uma aproximação mais estreita do tema do paternalismo com a questão do bem jurídico protegido, por exemplo, nos crimes sexuais que tenham como vítimas crianças e adolescentes, é digna de nota a preocupação de parcela relevante da doutrina de evitar o exercício de um tratamento paternalista estatal sobre a sexualidade dos menores.

Especificamente sobre as diversas facetas do paternalismo, é digno de nota o raciocínio desenvolvido por FEINBERG no sentido de que, quando se observa a intersecção entre moralismo e paternalismo, é considerada um bom motivo para a restrição da liberdade individual a situação na qual se busca proteger o indivíduo de dano contra si mesmo ou contra terceiros no aspecto moral (em oposição a casos que envolvem prejuízo físico ou econômico). Nas palavras do referido pensador, esse ponto de vista, que redunda em uma das principais razões invocadas para a proibição de pornografia, pode ser chamada de moralistic paternalism. $^{83}$

Assim, o mesmo autor apresenta uma série de motivos que devem servir de lastro para a legitimidade de algumas incriminações, podendo ser destacado, para auxílio ao nosso estudo sobre os limites relativos à pornografia infantil, o que ele denomina legal moralism. Consoante sua classificação, esse princípio traz subsídios para a penalização de todas as

81 GRECO, Luís. Posse de droga, privacidade, autonomia: reflexões a partir da decisão do Tribunal Constitucional argentino sobre a inconstitucionalidade do tipo penal de posse de droga com a finalidade de próprio consumo. Revista Brasileira de Ciências Criminais, São Paulo, v. 18, nº 87, nov./dez. 2010, p. 94.

82 Segundo MARCO SEGRE, "o princípio da autonomia confronta a postura paternalista (embasada nos princípios de não-maleficência e de beneficência da tradição hipocrática), levando as pessoas (...) a interferirem em questões que, em princípio, dizem respeito à esfera do indivíduo, pelo menos na concepção produzida pela cultura moderna ocidental." Ob. cit., p. 21.

${ }^{83}$ FEINBERG, Joel. The moral limits of the criminal Law. Harm to others. Vol. 1, Nova York: Oxford University Press, 1987, p. 12-13. 
condutas relacionadas às práticas sexuais "desviantes", como por exemplo as perversões sexuais, o adultério, a bigamia, a prostituição, as casas de sexo explícito ou os atos obscenos. ${ }^{84}$

Esse tipo de argumentação - utilizada para dar suporte à justificação de criminalização de determinadas condutas relativas à sexualidade humana - não pode conviver com os limites constitucionais de autonomia e autodeterminação individuais.

Com efeito, sempre será preciso sopesar os interesses em conflito sob o viés da ofensividade ou dos critérios da real proteção de bens jurídicos, sem a influência determinante de dados meramente morais ou "correcionais".

Afinal, como será desenvolvido mais à frente, ao tratar dos critérios de legitimação penal em determinados tipos penais no direito comparado e a temática da moral sexual coletiva, os perigos advindos do exagero no controle do comportamento sexual de jovens púberes (principalmente na faixa dos catorze ao dezoito anos) repousam na inadequada interferência do direito penal em assuntos de natureza íntima e privativa do indivíduo, havendo consequências nefastas ao alargamento da incidência da norma penal. Por isso, até para também ser respeitada proporcionalidade, será importante estabelecer diferenças entre a pornografia infantil e a juvenil (que envolva adolescentes).

Com isso, apenas a título de exemplo, MARIA DO CARMO SARAIVA DE MENEZES DIAS SILVA, em obra dedicada à sexualidade juvenil, ao criticar alguns aspectos da legislação portuguesa acerca da incriminação da prática de determinados atos sexuais com adolescentes na faixa etária indicada, alertou que "esta opção legislativa, que sugere a tal 'visão paternalista', significa desde logo um desvio à pretendida neutralidade do direito penal sexual, sendo certo que o suposto de que parte nem se adequa necessariamente às representações hoje dominantes nas sociedades liberais, nem, nessa medida, deve ser levada em conta pelo direito penal que é um instrumento de tutela subsidiária de bens jurídicos (e não de castigos da imoralidade, como nunca é demais repetir)". 85

\footnotetext{
${ }^{84}$ Ob. cit., p. 13.

${ }^{85}$ DIAS, Maria do Carmo Saraiva de Menezes da Silva. Crimes sexuais com adolescentes - particularidade dos artigos 174 e 175 do Código Penal português. Coimbra: Almedina, 2006, p. 241.
} 
Ou seja, em uma área tão delicada e tomada por tensões entre direitos e garantias fundamentais dos envolvidos como a do direito penal sexual, o enfoque paternalista derramado sobre o comportamento sexual das pessoas pode provocar efeitos deletérios e contrários ao próprio interesse do menor que se busca resguardar.

Aí reside a necessidade, sempre que possível e tendo em conta o sopesamento das variáveis de cunho cultural, ético e moral, de se afastar desse campo quaisquer resquícios manipuladores ou arbitrários sobre a disciplina penal da sexualidade humana, ainda que se esteja diante de pessoas sob o peculiar estágio de desenvolvimento (e tudo que isso pode significar $\left.{ }^{86}\right)$.

Bem por essa razão, ANABELA RODRIGUES afirma que "a visão paternalista do Estado, como entidade esclarecida que tudo pode impor em nome do verdadeiro bem dos cidadãos, sucumbiu irremediavelmente perante a instauração do Estado de direito material e a organização constitucional da democracia participativa, com os inerentes direitos e garantias, não podendo subsistir pelo simples fato de a concreta atividade estadual se dirigir a cidadãos menores". 87

Em suma, no que atina com o objeto da presente dissertação, tendo em vista essas classificações e o compromisso de um Estado de Direito para com o respeito ao livre desenvolvimento dos cidadãos, o importante é verificar até que ponto se poderá aceitar como justificável o paternalismo impuro consistente na proibição de pessoas adultas (portanto, competentes) de portarem material de cunho pornográfico infantil na sua modalidade simulada.

A questão que surge é: podemos justificar a criminalização desse tipo de conduta com base na proteção ao direito de desenvolvimento sadio da sexualidade de crianças e

\footnotetext{
${ }^{86}$ As especiais circunstâncias que envolvem a adolescência/juventude, no que diz respeito ao objeto de tutela dos chamados crimes sexuais serão apresentadas em tópico próprio.

${ }^{87}$ RODRIGUES,Anabela Miranda. Repensar o Direito de Menores em Portugal - Utopia ou Realidade? Em: RPCC, ano 7, fasc. 3. ${ }^{\circ}$, jul.-set. 1997, p. 358. Apud DIAS, Maria do Carmo..., ob.cit., p. 241, nota 447.
} 
adolescentes? Cuida-se de comportamento paternalista - indevido, contrário às noções de esfera privativa de liberdade - tal proceder legislativo?

Para responder a esses questionamentos, inevitável deitarmos o olhar sobre a definição e a abrangência do que se poderia denominar "esfera da vida privada", como um critério adicional à análise a respeito do tema relacionado à pornografia infantil.

\subsection{A "vida privada": a intimidade e a privacidade}

A autonomia privada também reforça a necessidade de o Estado zelar pela garantia a cada um dos cidadãos de que, em determinada esfera de sua vida, não pode ser importunado, mormente por meio da ameaça de uma pena.

A definição de autonomia privada, em termos etimológicos, remete à confluência dos termos gregos autos e nomos e do termo em latim privatus. Autos diz com a ideia de ação do próprio sujeito sobre si mesmo, enquanto que nomos configura a regra de comportamento nos ditames do direito (consuetudinário); já a palavra privatus significa tudo aquilo que é particular, pessoal, do cidadão.

Assim, daí decorre uma definição de autonomia privada que atina com a capacidade do indivíduo de, dentro de seus atributos próprios, impor a si mesmo uma regra autônoma de determinar, sem a interferência de outros, seu comportamento, sua conduta de vida.

Trata-se, como se vê, de um princípio norteador segundo o qual o tratamento jurídico das relações no seio da sociedade devem ter em conta a preponderância dos interesses privados em detrimento das diretrizes globais do Estado. Em outros termos, é preciso garantir o maior respeito possível aos direitos alheios e também uma interferência mínima do Estado 
nesses interesses particulares, por ocasião de se eleger como, onde, e quando a autoridade pública irá agir, tendo tal interferência nítido caráter residual e excepcional. ${ }^{88}$

Daí temos a ideia de relativização do conceito de autonomia privada, ou seja, segundo essas diretrizes, a interpretação dada a tal princípio não pode ser absoluta, tendo em vista a necessidade de ponderação e sopesamento com a autonomia dos outros indivíduos, bem como, da função social do Estado de Direito. Seria, assim, a autonomia, a capacidade de os cidadãos determinarem-se a si mesmos, sem qualquer ingerência estatal, em assuntos inerentes às suas personalidades. $^{89}$

Nessa conformidade, fica fácil perceber o relevante papel da autonomia privada na proibição de que os Estados possam criar discriminações com base em raça, cor, sexo, religião, idioma, opinião ou qualquer outra condição social..$^{90}$

O exame de limites impostos ao Poder constituído no tocante à criminalização de condutas com claro conteúdo discriminatório quanto à sexualidade humana, neste ponto, será fundamental ao presente estudo à exata medida que, em última análise, o aspecto sexual da personalidade do indivíduo, para justificar a violência estatal, deve, necessariamente, envolver algum tipo de comportamento lesivo à esfera de autonomia de outras pessoas.

Nesse momento, cabe estabelecer diferenças conceituais entre os termos vida privada, intimidade e privacidade, embora a doutrina em geral acabe, às vezes, empregando-os como se fossem sinônimos.

\footnotetext{
${ }^{88}$ MIRANDA, Rosângelo Rodrigues de. Ensaio sobre a tutela da autonomia privada na Convenção Americana de Direitos Humanos. Revista Jurídica do Ministério Público do Estado de Minas Gerais no 3, Belo Horizonte, jan./dez. 2001, p. 89.

${ }^{89}$ Tanto isso é verdade que a Convenção Americana de Direitos Humanos prevê, no preâmbulo do artigo $7 .^{\circ}$, a tutela da liberdade pessoal, comprometendo-se os países signatários a assegurarem, por meio de regimes democráticos, a cada indivíduo que usufruam de sua autonomia privada, permitindo-se "gozar dos seus direitos econômicos, sociais e culturais, bem como seus direitos políticos e civis." MIRANDA, Rosângelo..., ob. cit., p. 190.

${ }^{90}$ Consoante o artigo 12 da Declaração dos Direitos Humanos, aprovada pela ONU em 1948, "ninguém será sujeito a interferências na sua vida privada, na sua família, no seu lar, ou na sua correspondência, nem a ataques à sua honra e reputação. Todo homem tem direito à proteção da lei contra tais interferências ou ataques."
} 
Com efeito, enquanto esfera privada seria justamente algo mais amplo, que engloba diversos aspectos da vida do ser humano em sociedade e suas relações com outros indivíduos e com o próprio Estado, a intimidade aparece como algo mais restrito, mais reservado dessas relações, e que merece, também, respeito e tutela.

Em outras palavras, a esfera da vida privada pode ser subdivida em círculos concêntricos menores, na medida em que a intimidade vai se restringindo. No âmbito maior, estão compreendidos os acontecimentos que o indivíduo não quer ver no domínio público, sendo do conhecimento de um espectro determinado de pessoas. Já na esfera da intimidade, estão as conversas íntimas, as relações com pessoas próximas. E, por fim, haveria a noção mais restrita ainda, consistente no "direito à privacidade" (right of privacy) ou então "direito a ficar sozinho" (rigth to be let alone).$^{91}$

Há ainda autores na doutrina alemã, ainda, que distinguem a vida privada em dois conceitos que, embora próximos, não se misturam: a esfera individual e a esfera privada. No primeiro, o indivíduo satisfaz seus interesses como integrante do consórcio humano, devendo ter liberdade de relacionar-se, do modo que entender mais benéfico, com quem melhor lhe aprouver (estariam, aqui, o direito ao nome, à imagem e à reputação). Na esfera privada, estariam localizados os interesses da individualidade que buscam seu desenvolvimento no recato, na intimidade, e que reclamam uma proteção mais específica das intromissões externas. $^{92}$

Intimidade seria, então, uma das liberdades fundamentais de autodesenvolvimento do corpo, mente e espírito da pessoa, ou seja, "um sentimento (...) que existe nos ambientes

\footnotetext{
${ }^{91}$ Essa expressão tem sua origem histórica no ano de 1888, atribuída ao juiz da Suprema Corte norte-americana Thomas Cooley, e surgiu em um contexto no qual o direito conferiria imunidade às ameaças de cunho físico. Somente depois, em 1890, foi escrito um artigo intitulado "Direito à Privacidade", em que as opiniões daquele magistrado são tomadas como paradigma teórico-científico. BONILHA, Ínkari Coelho. O tratamento jurídicopenal do acesso não autorizado a sistema informático. São Paulo: 2006. Tese (Mestrado em Direito Penal). Faculdade de Direito, Universidade de São Paulo, São Paulo.

${ }^{92}$ FERREIRA, Ivette Senise. A intimidade e o direito penal. Revista Brasileira de Ciências Criminais, São Paulo, v. $2, n^{\circ} 5$, jan./mar. 1994, p. 99.
} 
interiores, mas se protege também no exterior para ser possível a liberdade de amar, pensar, sorrir, chorar, rezar, enfim, a liberdade de viver a própria vida e morrer a própria morte". ${ }^{93}$

Claro que há outras definições jurídicas do direito à intimidade, porém o aspecto comum a toda elas é justamente esse núcleo exclusivo que diz respeito apenas àquela pessoa, oponível a terceiros, e merecedor de respeito e tutela pelo Direito. Por exemplo, PAULO JOSÉ DA COSTA JÚNIOR a define como “o direito de estar só”. Seria, assim, a garantia concedida ao indivíduo de ficar em paz, de permanecer recolhido, ou então de subtrair-se à publicidade e não ser arrastado para a curiosidade alheia, contra a sua vontade. ${ }^{94}$

A questão da intimidade pode ser encarada, também, na seara da proibição de divulgação (e interferência) de informações exclusivas a uma dada pessoa, pois, no dizer de CELSO RIBEIRo BAStos, ela seria "a faculdade que tem cada indivíduo de obstar a intromissão de estranhos na sua vida privada e familiar, assim como de impedir-lhes o acesso a informações sobre a privacidade de cada um". ${ }^{95}$

Seja como for, fica claro o alcance da intimidade como algo secreto, afeito apenas e tão-somente àquele âmbito pessoal, exclusivo, em que o cidadão pode evitar a intervenção dos demais. É, portanto, oponível à intromissão dos outros.

A autonomia privada, pois, deve ser encarada sob o aspecto da intimidade/privacidade do cidadão, sendo fundamental estabelecer o alcance desses institutos, já que eles fazem parte da ideia de liberdade em sentido mais amplo, aí residindo a sua relevância ao presente estudo.

Qualquer tipo de norma imposta pelo Estado (ainda com mais razão previsões sancionatórias penais) para restringir, interferir, ditar o estilo de vida, o perfil psicológico (caráter), os aspectos da personalidade, da "formação moral" do cidadão - tudo dentro desse

\footnotetext{
${ }^{93}$ Conforme DOTTI, René Ariel. A liberdade e o direito à intimidade. Revista de Informação Legislativa, abr./jun. 1980, Brasília/DF, p. 130. Disponível na Biblioteca Digital do Senado Federal: http://www2.senado.gov.br/bdsf/item/id/181214.

94 O direito de estar só. Tutela penal da intimidade. $2^{\text {a }}$ ed. São Paulo: Revista dos Tribunais, 1995, p. 43.

${ }^{95}$ Curso de Direito Constitucional. 13 ${ }^{\mathrm{a}}$ ed., São Paulo: Saraiva, 1990, p. 180-181.
} 
âmbito privativo -, inevitavelmente, terá um efeito bastante deletério no tocante às liberdades públicas. ${ }^{96}$

\subsection{As liberdades e seu regime constitucional}

Ainda no âmbito da autonomia, para uma melhor compreensão do tema, torna-se preciso despender algumas breves considerações acerca da abordagem jurídico-constitucional acerca das dimensões do direito à liberdade.

Importante dizer, desde logo, que a liberdade aparece como sendo condição necessária, juntamente com a dignidade da pessoa e sua integridade, sem a qual o pleno desenvolvimento humano ficaria bastante prejudicado (ou até mesmo inviabilizado).

Com especial destaque, SAMANTHA RIBEIRO MEYER-PFLUG assevera a perda da razão de ser de outros direitos se o Estado não tivesse possibilidade de garantir o direito à liberdade, entendido aqui em sentido lato. Como conquista da sociedade, não se pode negar que tal direito antecede à própria noção do Estado, até porque está relacionado ao desenvolvimento das potencialidades humanas como instrumento imprescindível à busca da felicidade. $^{97}$

Com isso, até tendo em vista uma noção kantiana de liberdade, mostra-se preciso encarar o indivíduo não mais como mero instrumento estatal, senão como pessoa dotada de um plexo de caracteres racionais e personalíssimos que devem ser observados e respeitados pelo ordenamento jurídico.

\footnotetext{
${ }^{96}$ Aqui cabe um importante adendo: não se nega, é claro, que o papel do Estado de Bem-Estar Social, é promover políticas públicas tendentes a aprimorar as relações humanas, trazendo um ambiente favorável à pacificação da sociedade, à paz e justiça equitativa de todos. No entanto, o que se buscará refutar, neste trabalho, é a "instrumentalização moral" do indivíduo para alcançar tais fins.

${ }^{97}$ Liberdade de expressão e discurso do ódio. São Paulo: Revista dos Tribunais, 2009, p. 28.
} 
Pode-se falar na existência de diferentes tipos de liberdades, podendo tal conceito ser abarcado por diferentes ângulos. ${ }^{98}$ Muito embora esse não seja o objeto específico deste estudo, convém apontar, agora, duas espécies importantes de conceitos de liberdade: no sentido negativo e no sentido positivo. ${ }^{99}$

A denominada liberdade negativa (também tida como moderna) está atrelada à ideia de se impor medidas de restrição à influência do ente estatal na livre atividade dos indivíduos (critério de delimitação, de não-intromissão), ou seja, cuida-se do direito de o homem não sofre impedimentos, com raríssimas exceções, na prática de dadas condutas ou exteriorização de seus desejos. ${ }^{100}$

Por outro lado, o sentido positivo de liberdade (ou então liberdade antiga) é um pouco mais amplo e atina com a noção de se garantir ao indivíduo a participação no corpo político de uma sociedade de forma ativa, atuando na elaboração das decisões políticas.

Ou seja, a liberdade positiva não se satisfaz com mera falta de ingerência estatal na vida particular do cidadão, sendo necessário verificar se existem elementos previstos na norma para efetivo exercício. Trata-se do poder de autogoverno (ou de autodeterminação) de cada pessoa. $^{101}$

Tendo em vista o âmbito cognitivo a ser desenvolvido na presente monografia, importa-nos voltar as atenções à liberdade negativa, uma vez que a sexualidade e a forma de exercício dos direitos personalíssimos estão interligados com a imprescindibilidade de imposição de certos limites na atuação de terceiros perante a vida privada do cidadão.

\footnotetext{
${ }^{98}$ Somente à guisa de exemplo, LEONARDO LUIZ DE FIGUEIREDO COSTA apresenta uma distinção entre liberdade formal (no seu sentido clássico, de a pessoa conceber o que seria bom párea sua vida, sem interferências externas) e real (esta segunda com um viés mais voltado á doutrina comunista/socialista, de que apenas com a supressão da liberdade formal e a estatização dos meios de produção poder-se-ia ter um 'governo do povo'). Limites constitucionais do direito penal. Rio de Janeiro: Lumen Juris, 2007, p. 14.

${ }^{99}$ Essa noção foi desenvolvida por ISAIAH BERLIN, cf. COSTA, Leonardo..., ob. cit., p. 16.

${ }^{100}$ MEYER-PFLUG, SAMANTHA..., ob. cit., p. 29.

${ }^{101}$ LEONARDO LUIZ DE FIGUEIREDO COSTA lança mão de expressões que definem a diferença do alcance de ambas as liberdades: a negativa seria resumida em "liberdade de" (status negativus libertatis) enquanto que a positiva seria "liberdade para" (status positivus libertatis). Ob. cit., p. 16.
} 
Nesse aspecto, a liberdade surge como uma contraposição ao poder constituído, isto é, a ausência de obstáculos à livre fruição e ao exercício de determinada garantia ou direito, embasada na questão de resistência à opressão, ou então em direito de oposição. ${ }^{102}$

Está-se falando de um direito individual, porém com sua faceta social, já que é oponível ao Estado, devendo ser protegido (e até estimulado) o seu exercício sem restrições ou obstacularizações indevidas. ${ }^{103}$

Esclarecido, de modo resumido, o contexto das noções de liberdades, devemos voltar a atenção para um de seus aspectos negativos: a liberdade de pensamento, prevista no sistema jurídico-constitucional de tutela das liberdades, o que será útil para o desenrolar do trabalho.

É cediço que a liberdade de pensamento pode ser decomposta em outras duas: liberdade de consciência e liberdade de expressão (ou manifestação de pensamento), ambas com proteção pela Constituição Federal de 1988 (artigo 5º incisos IV e IX).

A noção de liberdade de pensamento engloba a livre fruição de ideias, sentimentos, sensações, convicções em seus mais diversos aspectos, tais como atividade intelectual, artística, comunicativa etc. Esse plexo de garantias é inviolável e constitui parte dos chamados direitos fundamentais do cidadão oponíveis ao Estado e merecedores de respeito.

Nesse sentido, conforme já dito, o Estado tem o dever de abster-se da prática de qualquer comportamento que coloque em risco ou limite tal direito ao livre pensamento, o qual constitui uma das mais caras e comezinhas garantias individuais com status constitucional.

\footnotetext{
${ }^{102}$ MEYER-PFLUG, Samantha..., ob. cit., p. 31.

${ }^{103}$ Em última análise, pode-se falar em uma "liberdade política", tendo em vista a possibilidade de o indivíduo cobrar de seus representantes, eleitos democraticamente, posturas concretas para a efetivação de proteção à sua esfera de intimidade.
} 
Com relação à liberdade de expressão, merece realce um aspecto polêmico que se aproxima do tema a ser abordado, qual seja, se essa garantia constitucional englobaria um direito à incitação à pornografia. ${ }^{104}$

O dilema reside em saber se a divulgação, ou a troca de arquivos, com conteúdo pornográfico estaria abarcado pelo direito de livre fruição e circulação de informações. Muito além de qualquer juízo de valor sobre se a pornografia causaria, ou não, embaraços ou prejuízos discriminatórios à figura feminina, a nosso ver, é incompatível com o nosso sistema de liberdades qualquer restrição ao direito individual de adquirir, possuir e divulgar esse tipo de material.

Já a problemática da propagação de pornografia de cunho eminentemente infantil envolvendo crianças ou adolescentes -, por envolver a participação de pessoas ainda em formação, terá de ser feita uma análise levando em conta essas especiais circunstâncias.

De uma maneira ou de outra, é inegável que o alcance da liberdade de consciência e pensamento - e também de expressão -, no tocante à forma como o indivíduo enxerga o mundo nos seus mais variados aspectos, configura importante paradigma quando o assunto é o exercício livre dos sentimentos atinentes à sexualidade, o que será retomado mais adiante.

Estabelecidas as bases sobre as quais repousa a noção de vida privada, será forçoso avançar um passo e tentar apontar critérios pré-definidos para desenvolver, até de forma empírica, a exata noção desta "esfera inviolável”, e, mais importante, se essas diretrizes poderão (ou não) servir de apoio para a posterior análise das questões penais referentes à pornografia infantil.

\footnotetext{
${ }^{104}$ O problema foi trazido por SAMANTHA RIBEIRO MEYER-PFLUG, ob. cit., p. 93-95. Apesar de, a todo momento, a autora destacar o caráter discriminatório da pornografia, diante do menosprezo em relação ao sexo feminino, (tratamento da mulher como objeto pela indústria pornográfica, gerando repulsa ou incômodo) destacando-se uma certa visão feminista do assunto -, conclui, citando DWORKIN, que não se pode proibir a sua divulgação, pois "as manifestações de expressão que são odiáveis e passíveis de repúdio por parte da sociedade têm tanto direito de proteção quanto qualquer outra manifestação." (p. 95).
} 


\subsection{A esfera de autonomia como "núcleo duro" inviolável: critérios possíveis}

Antes mesmo de questionar a respeito de eventual violação a um bem jurídico tutelado pela norma penal, surge a questão de saber se é possível afastar a legitimidade de incriminação de dada conduta utilizando-se de critérios relativos à esfera inviolável de autonomia.

Com isso, deixar-se-ia a discussão sobre eventuais medidas coercitivas na esfera extrapenal, sem precisar adentrar na avaliação empírica se foi afetado (ou ameaçado) algum interesse fundamental da sociedade que tornaria tal comportamento como "merecedor" de uma sanção penal.

De início, é conveniente esclarecer que o escopo do trabalho a ser desenvolvido não é, a priori, descartar os importantes marcos teóricos advindos com a teoria do bem jurídico, a qual já completou mais de 250 anos de existência. A ideia aqui é outra: procurar estabelecer diretrizes relacionadas à esfera inviolável da vida privada de um indivíduo como uma alternativa adicional à noção de tutela de bens jurídicos, sempre tendo em mente limitar o poder de interferência do Estado (limite negativo). Trata-se de se introduzir considerações adicionais para auxílio ao debate do tema.

Nessa conformidade, na tentativa de lançar critérios mais seguros da esfera de autonomia para o posterior exame dos tipos penais relativos à pornografia infantil, pede-se licença para apoderar de algumas sugestões trazidas por LUÍS GRECO em artigo publicado na Revista Brasileira de Ciências Criminais, no qual criticou decisão da Corte Constitucional argentina a respeito da inconstitucionalidade do porte de drogas para mero uso pessoal. ${ }^{105}$

\footnotetext{
105 Em linhas gerais, o mencionado artigo aponta como os principais argumentos da decisão argentina: $i$ ) a ineficácia da incriminação, já que os dados estatísticos oficiais recentes apontam para o aumento do consumo de drogas e ii) a esfera privada, já que esse direito fundamental, também reconhecido pelas convenções internacionais de direitos humanos, é elevado pela Constituição Argentina à categoria de limite de qualquer proibição. O primeiro argumento é rechaçado pelo autor do artigo, visto que "o fato de que o consumo de drogas tenha crescido não significa que a proibição seja ineficaz, pois - ainda que os dados levantados reflitam fielmente a realidade - não se pode saber se esses números não teriam subido ainda mais sem a proibição”. Já o segundo (e principal) argumento, ainda segundo o autor, é legítimo ante a correção do argumento de que o artigo 19 da CF argentina seria "manifestação da ideia liberal segundo a qual cada um tem o direito de seguir seu próprio plano de vida." GRECO, Luís. Posse de droga, privacidade, autonomia: reflexões a partir da decisão do Tribunal
} 
Vejamos, em breve análise, se o entendimento do autor alusivo aos limites de interferência utilizados na decisão sobre entorpecentes se enquadraria à análise específica feita nesta sede.

A primeira dessas diretrizes escora-se no caráter universal, segundo o qual todas as pessoas, a princípio, são dotadas de um campo autônomo de tomada de decisões que dizem respeito apenas a si próprias. O conteúdo da autonomia há de ser reconhecido aplicável a todos os indivíduos de igual forma, em igual medida, buscando-se um sopesamento extreme de privilégios.

A ideia central aqui desenvolvida dialoga com a afirmação de que a autonomia de um indivíduo não pode colidir com a de outro, ou então, mais do que isso, não se pode admitir que apenas um grupo restrito de pessoas goze de tal autonomia.

Ou seja, caso ocorra uma eventual "colisão de autonomias", está-se diante de hipótese que extrapola os limites do protegido ou imponderável. É preciso, então, ter em mente o respeito à autonomia de terceiros, proibindo-se a instrumentalização de um grupo determinado de pessoas, ocasião em que a adoção do critério se esvairia de sentido. ${ }^{106}$

Equivalência (igualdade entre os destinatários da imposição):

Nesse particular reside especial importância à questão da pornografia infantil. A adoção da ideia de autonomia inviolável é indissociável da noção de uma relativa igualdade entre aqueles que usufruem dela.

Constitucional argentino sobre a inconstitucionalidade do tipo penal de posse de droga com a finalidade de próprio consumo. Revista Brasileira de Ciências Criminais, São Paulo, v. 18, nº 87, nov./dez. 2010, p. 87.

${ }^{106}$ Exemplo interessante seria do sujeito que solta rojões dentro de casa, em uma região povoada com diversos edifícios, que poderia levar a danos materiais de grande monta ou a ofensas à incolumidade física e até à vida de terceiros. O indivíduo tem, evidentemente, autonomia para tal comportamento, no entanto, cabe observar se não há colidência com a autonomia dos outros membros da sociedade. 
Não obstante se pudesse, desde logo, dizer que o reconhecimento da autonomia presumiria a condição de capacidade intelectual da pessoa, o que excluiria a possibilidade de crianças gozarem de uma autonomia plena, LUÍS GRECO trabalha com a ideia de autonomia preferencial. Por isso, seria cabível dizer que, ao menos a rigor, elas não estariam fora da esfera de intimidade inviolável, uma vez que teriam uma liberdade mais restrita.

O mais importante será examinar o exemplo da posse de pornografia infantil virtual à luz da proibição de exploração a fim de se ver se essa conduta está localizada fora da esfera nuclear íntima, de um lado, e, em caso positivo, em um segundo momento, se tal comportamento seria passível de uma criminalização legítima em algum Estado Democrático de Direito.

Já adiantando o raciocínio a ser elaborado mais adiante, convém dizer que outros autores também traçam um paralelo entre a conduta de possuir material pornográfico infantil para consumo (sem intenção de divulgação ou propagação) e o delito de porte de entorpecente para uso próprio.

ALEXANDRE ASSUNÇÃO E SILVA, por exemplo, entende que "adquirir pornografia infantil para deleito próprio é semelhante à aquisição de drogas para uso próprio, conduta que não é mais punida com pena privativa de liberdade. (...) As condutas são semelhantes, pois tanto o consumo de drogas quanto o de pornografia infantil estimulam a prática de crimes. Quem consome drogas não prejudica só a si mesmo, pois o consumo incentiva o tráfico, que é responsável pela prática de inúmeros outros crimes, inclusive pelos próprios usuários". 107

Com efeito, considerando o fato de que o possuidor, que não interferiu nem participou na elaboração do material pornográfico infantil, tem como escopo apenas o deleite próprio, a semelhança entre as figuras é inegável. A questão é saber até que ponto seria válido, nos

\footnotetext{
${ }^{107}$ Violações a princípios constitucionais e penais na legislação de combate à pornografia infantil. Revista dos Tribunais 890, dez. 2009, p. 454.
} 
casos, por exemplo, de pornografia simulada, concluir pela ausência de incidência da norma penal em razão de tal conduta figurar no âmbito de autonomia do indivíduo. ${ }^{108}$

Diante do exposto, vê-se, a princípio, que a dúvida maior para se solucionar a questão do porte de material contendo cenas simuladas de crianças ou adolescentes em contexto sexual repousará na resposta à seguinte indagação: haveria uma "exploração" da autonomia das pessoas em situação de desenvolvimento, nesses casos, que afastaria a conclusão de tal comportamento estar localizado nessa esfera íntima?

A busca da melhor resposta a esse questionamento demandará uma necessária aproximação do estudo acerca da autonomia da vida privada aos aspectos permeadores das bases histórica e teórica da relação entre o obsceno, o pornográfico e o Direito Penal, bem como das justificativas de política criminal que levaram a tal proibição legal constante do ECA, no Brasil.

${ }^{108}$ CAMILA GARCIA E SILVA, de outro lado, entende que a comparação é indevida, "tendo em vista a dificuldade de estabelecer padrões mínimos de consumo, abastecimento e tráfico.”. GARCIA DA SILVA, Camila. Pornografia simples e qualificada. Revista de Ciências Penais, ano 9, n 16, 2012, p. 253. 


\section{CAPÍTULO 3 - O OBSCENO E O DIREITO PENAL}

Este capítulo tem como objetivo traçar uma análise acerca do conceito de obscenidade, e seu respectivo reflexo no ordenamento jurídico-penal, como forma de aproximação ao tema específico da sexualidade dos menores e da pornografia infantil em si mesma, a serem abordados nos capítulos seguintes.

Com isso, já se terá uma noção sobre a maneira pela qual tanto o Direito - de modo geral -, como o Direito Penal - em particular -, entendem a influência da moral e dos "bons costumes" na seara sexual. Comecemos com a evolução histórica dos conceitos em lume.

\subsection{Representações sexuais: breve origem histórica}

A representação da sexualidade humana, seja por meio de desenhos, imagens - e, mais recentemente, fotos, filmes e arquivos digitais - sempre esteve presente nos relatos históricos desde priscas eras.

Não é por outro motivo que "a arte primitiva — da qual depende grande parte da nossa especulação sobre a sexualidade humana primitiva - frequentemente retratava formas femininas. Arqueólogos encontraram estatuetas de Vênus, a deusa do amor, de grupos da Era do gelo e imediatamente posteriores. "109 Ou seja, até mesmo antes do surgimento da agricultura e de outras atividades socioeconômicas, pode-se afirmar que o ser humano tinha o hábito de retratar ou representar, de algum modo, as relações sexuais.

Aliás, um indicativo bastante eloquente da relação dos homens com imagens ou objetos representativos da sexualidade, seja na forma de retratar a nudez ou o ato sexual em si,

\footnotetext{
${ }^{109}$ Conforme o relato do Professor de História da Universidade Harvard PETER N. STEARNS, no livro História da Sexualidade. Rio de Janeiro: Zahar, 2010, p.23.
} 
remonta à famosa escultura conhecida como "Vênus de Willendorf", feita em calcário, e localizada por arqueólogos às margens de um rio no local onde atualmente fica uma pacata cidade austríaca. Segundo relatos, essa pequena estátua foi construída no período Paleolítico.

A civilização oriental, desde há muito, também desenvolveu a prática de representar atos voltados ao estímulo da libido, sendo exemplo disso o clássico Kama Sutra, livro milenar com um sem-número de posições sexuais representadas.

No entanto, voltar-se-á o olhar para o modo como a chamada civilização ocidental lida com a questão da representação da sexualidade, até porque qualquer tipo de dúvida com relação aos tipos penais relacionados com o tema poderá ser solucionada com um olhar ao passado.

A pornografia, tal qual conhecemos nos dias atuais, deita suas raízes no mundo das civilizações grega e romana. Na Antiguidade, os romanos, conhecidos por sua permissividade no tocante aos assuntos do sexo, tinham por hábito pintar nos muros dos povoados palavras de baixo calão, além de ser permitida a nudez nos banhos públicos.

De seu lado, os gregos conviviam, de maneira natural, com a nudez constante nas artes e nos esportes. Daí porque a produção artística e literária daquele período antigo pode ser entendida como livre do recato que veio a tomar conta da cultura ocidental em séculos posteriores. $^{110}$

Para ilustrar a cultura permissiva então vigente naquela época, segundo as palavras de LUIZ ROBERTO CICOGNA FAGGIONI, "a arte propriamente dita erótica, voltada a causar a excitação sexual, era largamente realizada em cerâmica (potes e ânforas), tanto na Grécia

\footnotetext{
${ }^{110}$ De acordo com as observações de RENATO DE MELLO JORGE SILVEIRA, "Grécia e Roma foram ápices no desenvolvimento humano. Também tiveram especialidades em como trabalhavam, social e juridicamente, o sexo. (...) Na Grécia antiga, desde a mitologia até as relações humanas, nota-se uma profunda presença sexual. (...) para a adoração aos deuses, os quais assumiam claramente esse viés de liberação de condutas, os gregos iniciaram cultos ligados ao sexo. (...) As proximidades de Roma com a Grécia e a usurpação de grande parte de uma cultura pela outra acabaram por gerar proximidades entre ambas as culturas no aspecto sexual. (...) a cultura greco-romana tinha, em paralelismo, as mesmas divindades, as quais se comportavam com certo grau de devassidão." Crimes sexuais..., ob. cit., p. 70-74.
} 
como em Roma, e usualmente ilustrava cenas de atos sexuais entre pessoas de sexos distintos e pessoas do mesmo sexo, e mesmo cenas de bestialismo. Tais objetos foram encontrados em larga escala, o que denota que seu uso era corriqueiro e não submetido á reprovação social.”111

A reviravolta conservadora, nesse campo, veio com a queda do Império Romano, sendo que acabou refletindo na forma pela qual o corpo (e todos os impulsos relacionados com a sexualidade) começou a ser visto como prisão e veneno da alma, o que refletiu nos valores sociais da Idade Média.

Com a introdução da Europa nos "Séculos das trevas", a Igreja Cristã impôs a sua noção de moralidade, calcada em um conjunto de dogmas reconhecidamente rigorosos, com uma leitura bastante peculiar das regras morais (exaltação do celibato e repressão do prazer sexual).

Assim, a mulher foi diabolizada, a sexualidade, controlada, a luxúria, reprimida e, por consequência, todas as manifestações artísticas relacionadas com a sexualidade, banidas ou controladas. A nudez era vista, neste período, com grande ambivalência, ao mesmo tempo inocente e símbolo do pecado.

Avançando no tempo, no século XVI, o Renascimento italiano procurou inspiração nas lendas e na mitologia dos heróis do Mundo Antigo, de forma que começou a se retratar histórias de conteúdo erótico. Como decorrência desse fenômeno artístico/cultural, houve certa popularização de um discurso erótico antes voltado apenas às classes mais abastadas (elite).

Convém destacar que, àquela época, a experiência da pornografia italiana chocava os padrões morais e políticos vigentes, tendo um grande caráter subversivo, tendo sido, inclusive, denominada de pornografia engajada. ${ }^{112}$

${ }^{111}$ O obsceno, o pornográfico e seu tratamento no Direito Penal. São Paulo: 2002. Tese (Doutoramento em Direito Penal). Faculdade de Direito, Universidade de São Paulo, p. 8.

${ }^{112}$ Pode-se afirmar que os escritos e as obras de cunho pornográfico tinham como objeto escandalizar a Igreja e a Nobreza, denunciando a hipocrisia daquelas classes dominantes. Isto é, "toda a pressão sofrida pelo cristianismo acabava tendo a contrapartida sátira dos trovadores. Poetas-músicos, de forma irônica ou metafórica, 
Mais adiante, o final do século XIX assistiu ao surgimento da fotografia comercial, e, em seguida, ao advento de uma nova forma de arte, o cinema. A pornografia logo se apropriou dos novos mecanismos, e uma revolução se materializava. A partir do final da segunda metade dos anos 1800, já eram publicadas revistas pornográficas, na Europa e mesmo no Brasil. ${ }^{113}$

Com relação à cultura erótica utilizada pela indústria cinematográfica, um bom exemplo de filme que chocou a moral dominante à época - e que, olhado hoje à luz do conteúdo veiculado principalmente nos programas televisivos (como novelas e séries), pode ser tido como algo até inofensivo - foi o clássico "O último tango em Paris”, protagonizado pelo famoso ator holywoodiano Marlon Brando. ${ }^{114}$

Nos dias atuais, com o avanço tecnológico — que se iniciou no final dos anos 1990 com a popularização dos chamados vídeos caseiros -, o advento da rede mundial de computadores (Internet), a facilidade de acesso, a garantia de anonimato e a velocidade da transmissão de dados digitais e das informações, existe uma verdadeira enxurrada de objetos/vídeos/fotos relacionados à pornografia.

glorificavam a mulher e o amor, sendo que isso sustenta as reformas e flexibilizações posteriores do sexo." SILVEIRA, Renato..., Crimes sexuais..., ob. cit., p. 91-92.

${ }^{113}$ Um marco da mudança cultural permissiva que se observou na segunda metade do século XX foi a criação da revista Playboy, em 1953, que se transformou em grande sucesso comercial em escala mundial. A partir daí, a representação fotográfica de mulheres nuas passou a ter um inegável status de mainstream, podendo ser encontrada em qualquer banca de jornal em diversos países.

${ }^{114}$ Importante mencionar que esse filme foi considerado "impróprio" no Brasil e em diversos outros países. Na Argentina, por exemplo, há decisão judicial que tomou o filme como "obsceno", por atentar ao pudor público. Segundo se lê na ementa do referido julgado: "Obscenidad. Film que reviste ese carácter. Objeto de tutela penal. 1. Lo obsceno es algo más que 1 impúdico, es lo que ofende torpemente el pudor. Se trata de un concepto valorativo cultural que depende de la sensibilidad moral media de un pueblo dado en un momento determinado, la que se quiere preservar de lo torpe, lo grosero, lo asqueroso, para evitar su paulatina degradación. 2. El film $E l$ ultimo tango en Paris contiene representaciones de actos contra natura, masturbaciones y otras formas de degeneración sexual, que, unidas al contenido de los monólogos durante algunas de esas escenas, resulta realmente grosero, e hiriente para la sensibilidad moral media de nuestro pueblo. Se trata, por ello, de una película cinematográfica obscena violatoria de los arts. 128 del C. Penal y 2 da Ley 18.019." Conforme destacado por GOTI, Jaime E. Malamud. La pornogafía y el derecho penal (Un ejemplo de paternalismo). Em: Doctrina Penal. Teoria y prática en las ciencias penales, Buenos Aires: Depalma, 1984, p. 499. 
É inegável que, atualmente, há uma indústria de produtos pornográficos, com um alargamento, pelo menos aparente, das margens do que seria "aceitável" com relação à representação da sexualidade. ${ }^{115}$

Tudo isso, por óbvio, acaba produzindo reflexos na maneira pela qual tanto a sociedade como os Governos (e, por que não, as próprias instâncias de controle e aplicação da repressão estatal), lidam com os novos padrões de comportamento e aceitação da produção, distribuição e comercialização desse tipo de material. ${ }^{116}$

Diante do aduzido, é importante notar como a sociedade no mundo ocidental vem lidando com os assuntos relativos às mais diferentes formas de representação da sexualidade, quase que de uma maneira esquizofrênica: às vezes apoiando a repressão, às vezes com um olhar mais liberal, já que é impossível analisar o assunto sem levar em consideração aspectos de natureza moral ou cultural.

De qualquer modo, a evolução do pensamento é fato inegável e deve influenciar as tomadas de decisões da sociedade quando o tema é pornografia ou representação do obsceno, conforme será visto mais adiante.

\subsection{Conceito dos termos "pornografia" e "obsceno"}

Ainda a título de introdução do tema objeto do presente capítulo, importante examinar os conceitos do que seria considerado pornográfico e obsceno para que tenhamos uma noção

\footnotetext{
${ }^{115}$ Apenas para que se tenha uma ideia do poder da referida indústria, cumpre destacar as informações trazidas pela antropóloga da Universidade Federal do Rio de Janeiro MARÍA ELVIRA DÍAS-BENÍTEZ, em trabalho acadêmico sobre a produção de filmes pornográficos no Brasil: "a cada ano, nos Estados Unidos, Hollywood produz cerca de 400 filmes, enquanto a indústria pornográfica põe no mercado entre 10 e 11 mil títulos. Os rendimentos obtidos com a pornografia no país - onde se incluem revistas, sites, televisão a cabo e brinquedos sexuais - são superiores aos gerados pelas indústrias do futebol, beisebol e do basquete juntas.” Nas redes do sexo. Os bastidores do pornô brasileiro. Rio de Janeiro: Zahar, 2010, p. 11 (destaques meus).

${ }^{116}$ Afinal de contas, não se pode esquecer que o Estado regulariza essa atividade, cobrando impostos, autorizando o comércio desse material, dado esse que deve ser levado em conta quando da análise da incidência das leis, principalmente as de cunho penal.
} 
do alcance das expressões e do âmbito de incidência das normas jurídicas sobre o tema.

Isso porque, na lei brasileira, sempre que o legislador quer disciplinar o controle ou a regulamentação da produção e da circulação de objetos/materiais, ou mesmo, tutelar o denominado pudor público no tocante à representação da sexualidade humana de maneira ofensiva ou criminosa, lança-se mão dos termos pornográfico ou obsceno, cada um deles com uma significação própria. ${ }^{117}$

Sem maiores aprofundamentos nas mais diversas variáveis acerca da conceituação de ambos os termos, pode-se afirmar que obsceno é tudo aquilo que, de alguma forma, traduz a reação de desgosto (ou incômodo, ou desconforto) - em suma, um sentimento de repulsa das pessoas diante de uma obra que fere o senso médio de pudor. ${ }^{118}$

O termo obsceno tem origem no latim obscenus, sendo considerado tudo que se volta contra o padrão (standart) de decência, relativo aos sentidos, ao pudor, do que seria repugnante, que desperta asco, sendo grosseiro, torpe. A ideia de ofensa ao decoro é bastante forte, estando presente na interpretação da referida expressão. Trata-se, como se vê, de um termo vago, um elemento normativo do tipo que depende de elementos extrajurídicos para completar o exercício exegético do intérprete da norma.

Válido destacar que a noção de obsceno não necessariamente precisa estar vinculada com obras (ou atos) de conteúdo sexual. Há situações em que a exposição sexual também pode ser tida como obscena, mas o traço verdadeiramente marcante deste termo diz com o caráter explícito, escandaloso, vulgar.

\footnotetext{
${ }^{118}$ Basta verificar, v.g., a utilização da palavra obsceno para designar os tipos penais previstos na Parte Especial, no capítulo do Código Penal referente ao "ultraje público ao pudor", mais precisamente os de ato obsceno (artigo 233) e escrito ou objeto obsceno (artigo 234) e, de outra banda, o uso da palavra "pornográfica" para designar o objeto material (cena pornográfica) dos delitos estampados no Estatuto da Criança e do Adolescente (artigos 240 e 241 da Lei 8.069/90).
} 
O fato de alguém, por exemplo, tentar ofender outra pessoa levantando o dedo médio de uma mão - gestuário bastante comum em brigas de trânsito - pode ser tido como obsceno, sem, necessariamente, que esteja presente o aspecto sexual. ${ }^{119}$ Ou seja, expressão corporal considerada vulgar, vil, está situada no campo de abrangência do conceito.

Quando trazemos a questão do obsceno para a temática do que choca os padrões médios da sociedade, percebemos que a linguagem - seja ela corporificada no idioma ou mesmo nos sinais corporais -, a fronteira entre aquilo que seria permitido (ou aceitável) e o que configuraria uma transgressão (reclamando proibição, portanto) acaba flexibilizando-se, fazendo surgir situações enquadradas em certa zona cinzenta. Nesses casos, o bom-senso e as circunstâncias concretas que permeiam a bagagem cultural de determinada sociedade serão fundamentais para checar até que ponto a proibição será legítima ou justificável.

Um episódio recente, no Brasil, mostra a problemática que marca todo e qualquer exame sobre os limites do obsceno, seja como desdobramento da liberdade de expressão, seja como algo desprezível a ser disciplinado pelo ordenamento jurídico - neste último caso, por meio da imposição de restrições administrativas (suspensão de obras, cortes de trechos censura) ou até mesmo da incriminação de condutas, com a previsão de sanção penal.

Após celeuma decorrente do teor considerado impróprio do objeto de palestra realizada por um Professor da História da Arte na Academia Brasileira de Letras - Jorge Coli ${ }^{120}$, o jornal 'Folha de São Paulo' publicou entrevista com o acadêmico, na qual foram analisados diversos aspectos da relação entre a obscenidade e obras artísticas ou científicas.

No ponto que interessa ao alcance do caráter obsceno de determinada expressão, o apontado Professor apresenta importantes considerações acerca da influência dos pilares

\footnotetext{
${ }^{119}$ Curioso lembrar o episódio em que um piloto de avião norte-americano, envolvido em grave acidente aéreo bastante noticiado pelos meios de comunicação (choque dos jatos da Gol e da Legacy), quando estava prestes a deixar o Brasil, fez o referido gesto em resposta ao assédio dos jornalistas. Por causa desse comportamento foi objeto de investigação pela suposta prática de ato obsceno.

${ }^{120}$ Conforme matéria publicada no dia 23 de setembro de 2012, no caderno "ilustríssima", pág. 3. Os aspectos sociológicos envolvidos no episódio serão tratados mais detidamente no tópico seguinte, em que se observará a relação entre a arte e o obsceno (ou pornográfico).
} 
morais na busca da definição do que deveria ser tido como aceitável em dado comportamento humano.

É o que passa, segundo ele, quando analisamos algumas expressões de linguagem ou algumas obras de arte. Ele cita como exemplo a tela "A Origem do Mundo", de Gustave Courbet. Perguntado pela reportagem sobre o motivo para uma pintura de 1866 ainda provocar tamanho choque a ponto de ser censurada em uma apresentação, esclareceu que "a tela conduz a uma situação esquizofrênica. É a exibição do obsceno (vulva) no campo do cênico (a arte). Em nome da arte, expõe-se a vulva. É esta a razão dos conflitos”.

Ao falar sobre a censura a um dos termos proferidos, verbalmente, na palestra, Jorge Coli sublinha a relevância da linguagem nesse campo do obsceno/proibido e traz curiosas considerações acerca do caráter obsceno de alguns palavrões: "é na linguagem que o peso dos interditos se revela mais facilmente. (...) Esse peso que os palavrões carregam consigo foram embutidos no nosso cerne desde a infância. Todos os que aprenderam uma língua estrangeira sabem que não há dificuldade nenhuma em pronunciar os termos mais cabeludos e arrepiantes no novo idioma: 'fuck', 'pussy', 'enculé', 'cazzo', 'troia'. Quando os incorporamos ao nosso vocabulário, ele nos chega sem a carga de autocensura repressiva engendrada na infância. Entre nativos, essas palavras desencadeiam grande mal-estar". ${ }^{121}$

Como se nota, a explanação sobre as diferentes reações que uma palavra considerada de baixo calão pode produzir em terceiros - e a flexibilidade dos conceitos de obsceno quando está no terreno pantanoso da linguagem - cai como uma luva sobre o quanto levantado até o momento, acerca da influência de critérios cambiantes de encarar essas expressões que chocam os interlocutores.

De fato, quanto maior o grau de aceitação social no uso de determinadas palavras ou expressões consideradas chulas, mais reforçada será a tolerância quanto a comportamentos

\footnotetext{
${ }^{121} \mathrm{O}$ entrevistado fecha seu raciocínio com uma postura irredutível perante práticas de censura, dizendo que "ao contrário dessa impressão negativa, as palavras chulas podem servir de estímulo erótico, sobretudo durante o ato sexual, porque ampliam o sentimento de transgressão, o sentimento de prazer proibido. Seja qual for a ressonância que uma palavra possa ter, ela não pode, nem deve, ser proibida. A censura que recai hoje sobre esses termos está vinculada à reação conservadora à que me referi”.
} 
tidos como desviantes, incluída aí, por exemplo, a simulação de pornografia infantil, tipo penal abordado no presente estudo.

A ideia de, em plena segunda década do século XXI, uma série de palavras terem sido excluídas (cortadas, mesmo) do texto original de uma palestra proferida na ABL tendo em vista apenas seu aspecto obsceno, acaba expondo o grau de conservadorismo em certos setores da sociedade civil brasileira. A proibição mostra-se, a rigor, inconcebível com o cabedal de princípios e vetores constitucionais, começando com a própria liberdade de expressão, como realçou o conferencista.

Assim, sob qualquer ângulo que se analise a questão, busca por critérios objetivos e bem delimitados quanto ao conceito de obscenidade revela tarefa difícil, árdua, já que sempre estará sujeita aos meandros subjetivos de quem examina cada caso concreto - e do conjunto de valores individuais. Daí porque a oscilação do alcance da obscenidade depende diretamente do caldo de cultura de determinado povo em dada época.

Por seu turno, o termo pornográfico origina-se do grego pornographos, e pode ser considerado todo escrito ou material de conteúdo sexual explícito que tem por escopo estimular a libido, a excitação do espectador ou daquele que tem contato com a obra ou o objeto.

A pornografia está atrelada à ideia de ideografia da sexualidade, da nudez, a representação do ato sexual de forma a causar uma reação estimulante no ouvinte ou no leitor/espectador. É relevante notar a intrínseca ligação com a noção de descrição, por qualquer forma de comunicação (cenas, escritos ou palavras faladas) da atividade sexual ou da nudez, visando uma reação de concupiscência. 
Pode ser considerado pornográfico todo o objeto ou espetáculo consistente em manifestações ou apelos de instinto sexual, expresso com a reprodução, com a representação, ou com a exibição de órgãos genitais. ${ }^{122}$

Nessa conformidade, em resumo, fica fácil perceber que obsceno e pornográfico não se confundem, tendo cada um o seu âmbito e sentido específicos, próprios, sendo que ambos, porém, são invocados pela lei para criminalizar condutas consideradas ofensivas ao pudor ou à moral pública, o que será examinado no próximo tópico.

\subsection{O obsceno e o artístico}

Em primeiro, é preciso destacar que, assim como a política de repressão ao álcool ("Lei Seca" nos Estados Unidos) e às drogas (no Brasil, a antiga Lei 6.368/76 e a atual Lei 11.343/06), a criminalização de atos obscenos ou impudicos ou as restrições à sua circulação, por diversos motivos, nunca foram capazes de eliminá-los.

E desde há muito, não só aqui como também em outros países do mundo ocidental, busca-se delinear limites e barreiras entre o que seria considerado pornográfico ou obsceno (portanto, ofensivo à lei penal) e o que se pode tomar apenas como artístico (fora, pois, do âmbito da incidência, já que socialmente tolerado).

Segundo o contexto histórico, no máximo, a eventual proibição/penalização incentivou o refinamento de obras, a aparência de sofisticação e de esforço intelectual, traçando uma linha entre o pornográfico (ou obsceno) repudiado e o pornográfico aceito (artístico). No

\footnotetext{
${ }^{122}$ Alguns autores, como LAURENT MOREILLON, introduzem no conceito de pornografia critérios puramente subjetivos ou que façam referência a diretrizes morais fluidas. Para esse autor, pornografia seria definida como toda representação de um comportamento sexual "deslocado de um contexto de relações humanas normais, tornando-o vulgar ou importuno. A definição abrangeria ainda cenas que visem a satisfação de instintos sexuais de maneira crua e provocante, em que as pessoas surjam como meros instrumentos de prazer". Apud LEITE, LEITE, INÊS FERREIRA. Pedofilia: repercussões das novas formas de criminalidade na teoria geral da infracção. Coimbra: Ed. Almedina, 2004, p. 53.
} 
entanto, a dúvida que paira no ar é a seguinte: até que ponto, sob a égide do atual Estado Constitucional, pode o intérprete do Direito continuar encampando esta separação, originada nos idos do século XIX?

Em uma tentativa de estabelecer um futuro exame mais detido - e crítico - da questão, imprescindível regressar ao pensamento de NELSON HUNGRIA, cuja obra "Comentários ao Código Penal" deixa transparecer sua opinião no sentido que deve haver uma diferenciação crítica entre aquele material considerado obsceno ou afrontoso à noção de "ultraje público" e, de outro lado, a obra de cunho meramente artístico. Vejam-se suas palavras:

"Segundo nosso modo de ver, não padece dúvida que cumpre distinguir entre a crassa pornografia ou o escrito fescenino e as manifestações realísticas da arte literária, entre a pintura ou escultura torpe, que servem ao objetivo único de

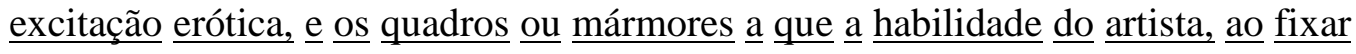

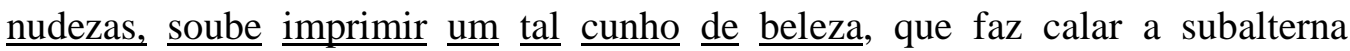
emoção lúbrica." 123

Ou seja, o julgador penal precisaria, dentro de critérios de discricionariedade e conveniência relativos a cada caso concreto - em verdadeiro papel de "crítico de arte" -, separar as situações tidas como grosseiras ou ultrajantes daquelas no qual se está diante de um trabalho de natureza artística ou científica. ${ }^{124}$

\footnotetext{
${ }^{123}$ HUNGRIA, Nelson; LACERDA, Romão C. de; FRAGOSO, Heleno Cláudio. Comentários ao Código Penal. vol. VIII. Arts. 197 a 249. $5^{\text {a }}$ ed. Rio de Janeiro: Forense, 1981, p. 310-311.

${ }^{124}$ Apenas para ilustrar o curioso da situação de "Jurista/crítico de arte", convém transcrever trecho no qual NELSON HUNGRIA flexiona sua verve crítica e não consegue esconder a ira sobre determinado trecho da obra "Capitães de Areia", de JORGE AMADO: "não se pode recusar o seu valor literário, nem a maestria com que o autor estuda um tema social na realidade palpitante; mas contém páginas que fariam tremer, no arrepio da concupiscência, as barbas de Xenócrates. O episódio de Pedro Bala com a negrinha na praia é pornografia grossa. Nada foi poupado ao leitor: nem mesmo o chulismo de linguagem do bodesco rapazola. Longe de nós o intuito de expor às iras da Justiça a JORGE AMADO ou a seus editores ou livreiros; mas tenho para mim que a citada página devia ser destacada e levada, senão para o "inferno" das bibliotecas, pelo menos para algum escaninho que se denominasse 'limbo"” (Ob. cit., p. 311-312-destaques e grifos nossos).
} 
A função do julgador penal, de acordo com esta posição doutrinária, seria a de determinar quais as manifestações artísticas, literárias, fotográficas ou cinematográficas de distribuição permitidas, e quais seriam as obscenas, legalmente proibidas.

É preciso certa cautela quando se concede ao exegeta da lei penal o poder de diferenciar, de discernir, o que seria obsceno ou pornográfico do que configuraria mera expressão de arte, fora do alcance, pois, da repressão estatal.

Com efeito, a postura do Estado em definir, com base em critérios vagos ou subjetivos, o que deve ser considerado "sério" ou de valor artístico e o que estaria localizado no âmbito do penalmente reprovável, como pornográfico/obsceno é, de certa maneira, perigoso, à medida que dá ao Juiz poderes quase que ilimitados para estabelecer os padrões de moralidade aceitos pela sociedade.

No entanto, cabe lembrar que, além de, no mais das vezes, existir um claro preconceito com relação a algumas práticas pornográficas relacionadas com a exploração de imagens menos sutis (ou menos convencionais), o cerne da questão repousa no desconforto de deixar a cargo do Julgador a palavra final sobre o que deve ser "normal" ou aceitável e o que deve ser punido com o rigor da intervenção do direito penal.

Ora, jogando um olhar crítico sobre tal diferenciação, percebe-se a ausência de lastro valorativo seguro sobre o que pode ser definido como um padrão comunitário contemporâneo a respeito do que pode ser comercializado ou exibido sobre material pornográfico ou obsceno.

Aliás, conforme já analisado no primeiro capítulo, a questão que realmente merece ser debatida atina com a falta de critérios objetivos claros acerca da fixação do conceito de moral ou pudor públicos, de tal forma que a concentração de tal poder nas mãos do EstadoJuiz pode levar a perigosa situação de insegurança jurídica. E mais: pode transformar a figura do Magistrado, repita-se, em crítico de arte ou analista de costumes, o que se revelaria no mínimo arriscado, dadas as idiossincrasias e as subjetividades inerentes a cada julgador. 
Por isso, a eventual abolição da diferenciação artificial da velha dicotomia artístico $x$ pornográfico, ao menos para fins de incidência do Direito Penal - afinal de contas, inegavelmente instrumento de ultima e não de prima ratio -, poderia resultar em tratamento mais igualitário ou democrático da questão, sem preconceitos ou indagações a respeito da finalidade obscena, ou não, do autor da obra.

Tudo o que foi dito acerca de obra de arte também pode ser aplicado a outras atividades humanas típicas de nosso tempo, como peças publicitárias, por exemplo. Aliás, a respeito do enquadramento (ou não) de determinada campanha de marketing, no conceito de material obsceno, acontecimento recentíssimo na Inglaterra, em razão da publicação de fotos de jovens modelos em trajes mínimos - praticamente seminuas - reascendeu a discussão quanto aos limites do estético e do obsceno, demonstrando a atualidade do tema.

Com efeito, segundo noticiado no periódico “The Guardian”, uma série de anúncios da marca norte-americana de roupas American Apparel foi proibida pelas autoridades britânicas. As fotos do catálogo publicitário, que contêm mulheres seminuas, foram consideradas "pornográficas e abusivas" pelo órgão responsável por regular a publicidade na Inglaterra. $^{125}$

Conforme declarado por referido órgão, a nudez seria desnecessária, justamente porque a maior parte dos produtos à venda não se tratavam de lingeries, e mesmo assim os seios e as nádegas eram o foco das imagens. Ademais, e no que mais interessa ao objeto de nosso estudo, a entidade alegou, para dar suporte à sua deliberação, que a aparente qualidade

\footnotetext{
${ }^{125}$ Em uma comparação livre, tal instituição seria o equivalente ao CONAR (Conselho de Autorregulamentação Publicitária), órgão não-governamental brasileiro, formado por publicitários e profissionais de outras áreas, responsável pela fiscalização do conteúdo de anúncios em todos os tipos de mídia, sempre buscando proteger o direito do consumidor em face de propaganda enganosa ou abusiva. Segundo consta de sua home page na Internet, o CONAR tem como missão " impedir que a publicidade enganosa ou abusiva cause constrangimento ao consumidor ou a empresas. (...) visa promover a liberdade de expressão publicitária e defender as prerrogativas constitucionais da propaganda comercial. Sua missão inclui principalmente o atendimento a denúncias de consumidores, autoridades, associados ou formuladas pelos integrantes da própria diretoria. As denúncias são julgadas pelo Conselho de Ética, (...) O CONAR não exerce censura prévia sobre peças publicitárias, já que se ocupa somente do que está sendo ou foi veiculado." (informações extraída da página: http://www.conar.org.br/ ).
} 
"amadora" das imagens serviria para dar a impressão, no seu sentir, inapropriada de "sexualização de mulheres mais novas".

Diante da celeuma instaurada, a referida empresa de comércio de roupas rebateu a decisão invocando dois argumentos interessantes, e que estão relacionados ao objeto de nosso estudo: em primeiro lugar, argumentou que as mulheres tinham claramente mais do que vinte anos; e para completar, aduziu também que as imagens são como aquelas que as pessoas normalmente compartilham com seus amigos em redes sociais e que as pessoas podem se identificar com elas. $^{126}$

Aliás, ultimamente a imprensa vem noticiando diversos episódios de cesura ou de restrições a determinados tipos de materiais (obras literárias ou artísticas) considerados obscenos ou pornográficos, o que reforça, mais do que nunca, a atualidade do tema em discussão e as diversas formas de encarar a questão da obscenidade e os limites de até onde se pode falar em material aceitável segundo os padrões vigentes.

Com efeito, conforme noticiado no periódico Folha de São Paulo em data bastante recente $^{127}$, em pelo menos três situações, em diferentes contextos, a discussão sobre os limites da arte ou da literatura vieram à baila. E todos, de alguma maneira, envolvem a imposição, por parte de autoridades públicas ou particulares, de restrições com preocupante caráter de censura.

O primeiro episódio foi protagonizado pela Academia Brasileira de Letras e tem como chamada a manchete "Historiador reclama de censura da ABL em conferência sobre sexo”. Segundo a reportagem, o professor de História da Arte Jorge Coli reclamou que excertos de sua conferência, cujo tema era "Sexo Não é Mais o Que Era”, proferida no âmbito

126 Cf. reportagem publicada no portal UOL, disponível em http://economia.uol.com.br/ultimasnoticias/redacao/2012/04/04/anuncio-pornografico-e-abusivo-e-banido-na-inglaterra.jhtm, $\begin{array}{lll}\text { acessado } & \mathrm{em}\end{array}$ 05.09.2012. Além do texto jornalístico, são apresentadas algumas das polêmicas fotos, ficando claro, a nosso ver, o excesso da interpretação fiscalizatória, uma vez que, afora uma ou outra pose mais provocante, o escopo da campanha é tão-somente o de realçar a beleza (aspecto estético) das modelos.

${ }^{127}$ Folha de São Paulo, edição de 15 de setembro de 2012, caderno "Ilustrada", página E-7. O mais curioso é que esses três casos aparecem relatados na mesma página, demonstrando que essa tendência controladora, quando o assunto está relacionado com a representação da sexualidade humana, não está perto de se extinguir. 
do ciclo "Mutações", no auditório da ABL, no Rio de Janeiro, foram deliberadamente suprimidos pela organização do evento.

De acordo com as queixas do acadêmico, foram cortadas da transmissão palavras do discurso dele, bem como imagens utilizadas na palestra ${ }^{128}$, diante do seu suposto caráter “obsceno" ou ofensivo. Suas declarações sintetizam a indignação diante das supressões e situam o verdadeiro contexto informativo da exposição: "Fiquei chocado. Tudo foi colocado dentro de um contexto de reflexão. Foi censura", afirmou o Professor, atribuindo os cortes à ABL.

A reportagem intitulada “Apple censura título de livro feminista de Naomi Wolf” traz a notícia de que, na contramão do contexto permissivo do mundo atual, um livro de conteúdo científico e cultural sobre o órgão feminino chamado "Vagina: A New Biography" também teve trechos censuras pela gigante empresa norte-americana. Para se ter uma ideia, de acordo com a matéria jornalística, o título da obra é apresentado como "V****a" na loja virtual do iTunes. E prossegue a reportagem, informando que "no texto descritivo, o mesmo tratamento acontece todas as vezes que a palavra 'vagina' é citada".

A reação da autora, quando soube do fato, foi imediata, conforme postado em seu blog: "Vocês não vão acreditar: eu soube que a Apple está censurando 'Vagina; A New Biography" no iTunes, embora palavrões são permitidos".

Ainda consoante noticiado, o tratamento puritano da Apple não é exclusividade de Naomi Wolf. "O clássico 'Monólogos da Vagina', de Eve Ensler, também recebeu os famigerados asteriscos. E até um episódio da série 'Girls' foi rebatizado de 'V****a Panic' no iTunes. $^{129}$

\footnotetext{
${ }^{128}$ Chama a atenção que uma das representações gráficas censuradas tenha sido a famosa obra "A Origem do Mundo" (1866), de Gustave Courbet, que mostra uma mera foto de um corpo feminino desnudo, com os órgãos genitais à mostra, sem qualquer caráter libidinoso ou lascivo.

${ }^{129}$ Ao final, nesse ponto, a matéria comenta que o critério da gigante multinacional é errático, já que, por exemplo, muito embora a palavra 'pênis' seja retirada de algumas obras literárias e até de podcasts da área da saúde, o termo aparece no livro 'Why Is The Penis Shaped Like That?', de Jesse Bering.
} 
Por fim, o terceiro episódio digno de realce é a reação negativa de alguns seguimentos do movimento feminista a respeito do best seller "Cinquenta Tons de Cinza" ("Fifty Shades of Grey"), da autora norte-americana E. L. James, obra que retrata um romance de um bilionário controlador e uma jovem universitária, com contornos levemente sadomasoquistas $^{130}$.

Retrata a matéria que "embora considere o uso do rótulo [pornô para mamães] ofensivo às mulheres, James sofre diversas críticas de grupos feministas, que discordam da relação de submissão total - e não apenas sexual - entre Steele e Grey [os personagens principais do romance] e que veem nisso um retrocesso para a sociedade" ${ }^{\text {"131. }}$.

Ou seja, uma vez mais, no contexto contemporâneo, apenas por retratar uma relação interpessoal alheia ao padrão familiar socialmente tido como a regra, o romance da autora, muito embora tenha alcançado extraordinário sucesso comercial, ainda é visto com certa cautela ou recalque por parte de seguimentos mais conservadores da sociedade.

O fato de a referida obra invocar um caráter de dominação/submissão entre os personagens principais, além da óbvia diferença de idade e de condição sócio-econômica entre eles, são circunstâncias que, por si só, já provocaram a ira do movimento feminista contrário à estigmatização da mulher como objeto sexual. No entanto, para tal linha ideológica, não se chega a questionar se não seria legítimo aceitar tal circunstância desde que a mulher queria estar nessa situação como parte do jogo de sedução.

Diante de todos esses exemplos, basta ficar atento com o noticiário cotidiano para se verificar que, em pleno século XXI, ainda causa polêmica a intersecção entre o obsceno e o

\footnotetext{
${ }^{130}$ Considerável setor da imprensa e da crítica especializadas apelidou a obra com o interessante termo "pornô para mamães", já que trata de assunto "picante" de uma forma mais leve, mais velada.

"131 A reportagem vem estampada com o título "Cinquenta Tons' é sobre amor, diz autora", cujo subtítulo é "Segundo E. L. James, trilogia vai além da relação erótica e de submissão; segundo volume chega hoje ao Brasil". Folha de São Paulo, edição de 15 de setembro de 2012, caderno "Ilustrada", página E-7. Um interessante trecho destacado diz que "para escritora, lançar o livro em e-book lhe permitiu escrever a história que queria, sem interferências", o que demonstra o poder de influência do universo virtual para a propagação de todo e qualquer tipo de informação. Esse aspecto da facilidade de disseminação de dados pela Internet será de extrema importância quando nos debruçarmos sobre a questão técnica da pornografia infantil virtual (ou pseudopornografia).
} 
artístico, tratando-se de um sinal dos tempos a imposição de posturas autoritárias ao censurar dado trabalho considerado ofensivo aos bons costumes.

Esse viés limitador da liberdade de expressão (aqui no seu aspecto artístico/literário), em diferentes lugares e situações, em nome de uma proteção da moral social apenas reforça a necessidade de se olhar para esse contexto com cautela, já que se pode descambar para um campo muito fluido da subjetividade. ${ }^{132}$

Voltando ao assunto da polêmica instaurada com a censura ao Professor de História do Sexo na ABL, em entrevista ao periódico Folha de São Paulo, após ser indagado se haveria diluição das fronteiras entre erotismo e pornografia com a nova realidade na internet, e se por isso seria preciso redefinir esses conceitos, trouxe uma informação interessante ao debate do tema em destaque. Disse que "não é preciso definir, porque eles nunca foram, de fato, definidos. São termos imprecisos e flutuantes. Pornografia é o erotismo do outro. Pornografia é um preconceito moral. Erotismo é um álibi moral. Resta o fato de que o imenso acervo pornográfico da Internet expôs, de modo envergonhado, a violência dos desejos sexuais no campo do imaginário". 133

Em outra passagem, à questão formulada se elevar a pornografia ao status de arte anularia seu caráter subversivo, o acadêmico respondeu com elementos que, por certo, ajudam a fixar a extensão do conceito de pornográfico/obsceno, sendo de grande valia às nossas

\footnotetext{
${ }^{132}$ Tanto isso é verdade que a celeuma intelectual instaurada para se esclarecer a eventual ocorrência (ou não) de censura com relação ao episódio envolvendo cortes na ABL acabou tendo desdobramentos, com a publicação, uma semana depois, de entrevista realizada com o professor Jorge Coli no caderno "ilustríssima" do mesmo periódico Folha de São Paulo. Algumas ideias discutidas pelo referido acadêmico - muitas delas atinentes aos rumos do conservadorismo em época de troca incessante de dados e informações pelos ambientes virtuais, o que coincide com o objeto do presente estudo - merecem destaque para tentarmos trazer mais elementos sobre os rumos atuais e futuros da dicotomia "obsceno v. artístico/científico".

${ }^{133}$ Coli apresenta três dados empíricos para dar comprovar que, nesse campo do consumo de pornografia, impera uma hipocrisia latente, já que a procura por esse tipo de material é bem maior do que se imaginava. O primeiro deles advém de situação publicada no site da Universidade de Montreal, em que "queriam fazer uma pesquisa sobre o comportamento de homens de 20 anos que consomem pornografia. Para tanto, precisavam de dois grupos: os que consomem, e os que não consomem. Não conseguiram encontrar um só para o segundo." Outra constatação inusitada: no dia 11 de setembro de 2001, o volume de acessos de busca por páginas de conteúdo sexual superou o de informações sobre o atentado às torres gêmeas. Por fim, há um resultado da mencionada pesquisa canadense que revela a média etária em que se inicia o contato com pornografia cravada em nada menos do que dez anos de idade. Veja-se que tudo isso apenas comprova a abissal diferença entre o imaginário e o mundo real quando o assunto é pornografia/obscenidade. O caráter pedagógico-persuasório da lei penal, nesse âmbito da sexualidade, acaba sendo de relativa e duvidosa incidência.
} 
futuras objeções sobre o tipo penal da posse de material infantil. Afirmou o Professor: "a pornografia tem um forte potencial subversivo porque abala os bons comportamentos morais. Há algo de rebelde na pornografia, algo que está continuamente presente, mas apenas de modo subterrâneo. A arte, que é uma categoria social elevada, ao incorporar a sexualidade explícita, serve-se do álibi cultural para manifestá-la.”. Mais adiante, explicou que "ao expôla, a arte põe em confronto público o espectador e seus fantasmas. São duas formas de subversão: uma oculta e brutal, outra manifesta e insidiosa".

Compatibilizando tudo o que foi colocado pelo apontado Professor da História da Arte com o quanto abordado até o momento, verifica-se, ainda atualmente, que os vetores moralistas (ou conservadores, ou puritanos), aplicados ao exame de determinadas publicações ou obras artísticas, acaba levando as discussões ao embate entre a predominância de uma moral pública (ou social) sobre a liberdade de expressão artística.

Por isso, é muito difícil enveredar-se por essas temáticas sem fugir do chamado caráter subversivo da pornografia, bem como, das inegáveis influências de aspecto religioso/ideológico quanto à questão da "culpa", muito presente nos julgamentos morais de obras que tais. E daí para descambarmos para o território do arbítrio, do preconceito, da condenação do feio, do diferente, do heterodoxo, é um passo mínimo.

E isso, em palavras mais diretas, representa a arcaica (e ressuscitada) censura, prática incondizente com os avanços democráticos conquistados a tão duras penas no Brasil. Afinal, ficam as perguntas: quem determinará o que é artístico e o que é obsceno? O que deve ser considerado chocante em matéria de livre expressão artística? Até onde se pode legitimar o corte unilateral de palavras de baixo calão de uma conferência pública, em um contexto de análise da história da sexualidade humana?

De qualquer forma, é preciso que se diga, segundo nosso ponto de vista, práticas de censura nunca devem ser tomadas como naturais em Estados liberais, onde reina o regime 
democrático, ainda mais em se considerar o grau de avanço nessa área quando se compara a realidade atual com o puritanismo não muito distante, do início do século passado. ${ }^{134}$

Por tudo isso, há que respeitar as majoritárias opiniões em sentido contrário, segundo as quais há de se verificar qual o sentido e a intenção do autor da obra que contenha representações sexuais ou de nudez.

O mais importante é que seja jogada uma luz à discussão sobre a pertinência de o Estado definir o que é obsceno/pornográfico e o que estaria abarcado pelo conceito de penalmente reprovável nessa matéria.

\footnotetext{
${ }^{134}$ Mesmo assim, é bom que se diga, ainda observamos na realidade cotidiana retrocessos nesse campo. Apenas para ilustrar, em reportagem divulgada nos dias atuais, uma garota norte-americana foi proibida de frequentar aulas em sua escola por estar trajada com uma camiseta, imitando o logotipo mundialmente conhecido da "Cocacola", com os dizeres "eu gosto de vagina". Segundo o publicado, "a estudante bissexual Brianna Demato foi impedida de assistir às aulas na última terça-feira (2) por usar uma camiseta em que estava escrito "eu gosto de vagina'. Os funcionários da escola Newton High School, em Nova York, teriam considerado a camiseta 'muito distrativa"”. Em resposta, demonstrando clara indignação e alegando ter tido sua liberdade de expressão violada, a garota reagiu: "'É hipocrisia', disse Brianna ao New York Daily News, "Eles usam a palavra durante a aula. Por que eu não posso usá-la em uma camiseta?". Ela conta ter sido vista por um funcionário durante o horário de almoço no refeitório, que pediu para que ela trocasse de camiseta ou fosse embora. A mãe da garota, Cathy Demato, disse ao jornal Daily News que o ato foi discriminatório. 'Ela não está prejudicando ninguém', disse, 'Ela pode usar a camiseta que quiser'”. (reportagem disponível em http://educacao.uol.com.br/noticias/2012/10/04/garota-bissexual-e-impedida-de-assistir-aula-por-usar-camisetaeu-gosto-de-vagina-nos-eua.htm, acessada em 04 de outubro de 2012). Daí já é possível averiguar as polêmicas ainda presentes nesse campo do obsceno nos dias que correm. Os movimentos pendulares no tocante à moral pública não nos deixam antever como a sociedade vai continuar reagindo a esses tipos de episódios, os quais, de um lado, tendem a aumentar (vide as demonstrações de afeto em público por casais homossexuais, o que significa inegável avanço libertário ou então as manifestações do estilo cultuado pelo grupo ucraniano Femen e de sua "filial" brasileira "Marcha das Vadias", em que mulheres utilizam de sua nudez para fins de protesto), e, de outro, vão sofrer repressões de setores mais conservadores. $O$ exemplo de censura contra a garota bissexual aqui noticiado apenas nos faz refletir e concluir que o futuro, nesse aspecto, permanece uma verdadeira incógnita.
} 


\subsection{Abordagem jurídico-penal}

\subsubsection{Breve evolução legislativa no Brasil}

Em primeiro plano, é indispensável alertar para a vagueza e a indefinição dos termos presentes nas leis penais com relação ao que deve ser criminalizado ou punido quando o assunto é a exposição de material pornográfico ou obsceno. ${ }^{135}$

Mais do que isso, o legislador, de modo geral, acaba tendo uma postura vacilante até mesmo sobre qual seria o valor ou bem jurídico que busca tutelar quando prevê essa espécie de delito, limitando-se a fazer referência a expressões vazias ou fluidas, como "ultraje público ao pudor" ou então moralidade pública.

De toda a forma, interessante verificar como se comporta a legislação de alguns países. Conforme destacado por LUIZ RÉGIS PRADO, ao traçar um brevíssimo relato sobre a disciplina de certas nações europeias, “o Código de Napoleão, de 1810, foi o primeiro a dispor sobre o referido crime, no artigo 287, punindo-o com pena de prisão e multa, além do confisco dos escritos e objetos. Também no século passado passaram a reprimir a aludida conduta os Códigos toscano, de 1853, e o alemão, de 1871". ${ }^{136}$

\footnotetext{
${ }^{135}$ Uma interessante exceção que merece destaque é o ordenamento jurídico italiano, que, diferentemente da maioria dos países com proximidade cultural com a realidade brasileira, apresenta uma definição legal do que deve ser considerado ato e objeto obsceno, vigente até hoje. Segundo o artigo 529 do CP italiano: "529. Atos e objetos obscenos: noção. À luz dos efeitos da lei penal, consideram-se obscenos os atos e objetos que, segundo o sentimento global, ofendam o pudor. Excetuam-se de tal pressuposto as obras de arte científica a menos que, por motivo distinto de seu objeto, se ofereçam à venda, sejam vendidos ou sejam colocados à disposição a menores de dezoito anos". Cf. FERNÁNDEZ, David L. Morillas. Los delitos de pornografía infantil en el derecho comparado. Em: Cuadernos de política criminal. Segunda época, Madrid: Centro de Estudios Superiores de Especialidades Jurídicas, 2004, p. 36. A definição legal do conceito serve sempre de norte aos operadores do Direito que tratam com essa matéria.

${ }^{136}$ Curso de direito penal brasileiro, vol. 3: parte especial, arts. 184 a 288. $2^{\text {a }}$ edição. São Paulo: Revista dos Tribunais, 2002, p. 320-321.
} 
No tocante à legislação brasileira, "O Código Criminal de 1830 previu tal delito no artigo 279. Também tratou da matéria o Código de 1890, no artigo 282, embora com redação defeituosa, que foi corrigida pela Lei de Imprensa de 1923."137

Como se vê, ambos os Códigos fazem referência à moral e aos bons costumes, ou então definem condutas que escandalizem ou ultrajam a sociedade, tudo a comprovar a inadequação dos termos aos ditames de um Direito Penal atrelado à princípio da estrita legalidade ou que proíbe a adoção de tipos penais abertos ou indefinidos.

Feita a breve explanação sobre a origem legislativa, voltemos o olhar para os tipos penais em vigor que disciplinam a matéria relativa ao material pornográfico ou obsceno.

\subsubsection{Os delitos de ato obsceno e de escrito ou objeto obsceno (artigos 233 e 234 do Código Penal)}

Os artigos 233 e 234, ambos do Código Penal de 1940 (crimes de ato obsceno e de escrito ou objeto obsceno), tutelam, segundo a doutrina penal majoritária, o bem jurídicopenal moral pública: a lei protege não só o pudor público, que é o sentimento médio de moralidade sob o ponto de vista sexual (pudicícia do homo medius), como assegura os bons costumes, que dizem com o decoro, conveniência e reserva usuais, no tocante aos fatos sexuais (conduta ético-social). ${ }^{138}$

\footnotetext{
137 PRADO, Luiz..., ob. cit., p. 320. Curioso verificar a redação original dos referidos dispositivos. Código Criminal de 1830. "Parte quarta. Dos crimes policiaes. Capítulo I - Offensas da religião, da moral e dos bons costumes (...) Art. 279. Offender evidentemente a moral publica, em papeis impressos, lithographados, ou gravados, ou em estampas, e pinturas, que se distribuirem por mais de quinze pessoas, e bem assim a respeito destas, que estejam expostas publicamente á venda. Penas - de prisão por dous a seis mezes, de multa correspondente á metade do tempo, e de perda das estampas, e pinturas, ou na falta dellas, do seu valor." Código Penal de 1890: "Capítulo V - Do Utrage Publico ao Pudor Art. 282. offender os bons costumes com exhibições impudicas, actos ou gestos obscenos, attentatorios do pudor, praticados em logar publico ou frequentado pelo publico, e que, sem offensa á honestidade individual de pessoa, ultrajam e escandalisam a sociedade: Pena - de prisão cellular por um a seis mezes."

${ }^{138}$ Segundo o entendimento abraçado por TADEU DIX DA SILVA, "não se trata, assim, do pudor individual: o que o Código Penal de 1940 visa com essa proteção é a 'moralidade pública', relativa à esfera sexual', tendo em
} 
Os tipos penais em questão, é bom salientar, apresentam alta carga valorativa, uma vez que o elemento normativo comum a ambos repousa no caráter obsceno, chocante da própria conduta (ato no artigo 233 e escrito pornográfico no artigo 234 do Código Penal), no que dependem, em grande margem, do conjunto de valores vigentes em determinada época.

A fim de apreender o conceito do bem jurídico no capítulo denominado "Do ultraje público ao pudor", trata-se fundamental verificar os hábitos e os valores sociais flexíveis que marcam uma sociedade em determinado lugar e tempo. ${ }^{139}$

Fica fácil notar, diante do exposto, o extremo caráter calcado pela mutabilidade da noção de pudor público ou de ato capaz de abalar as estruturas morais eleitas por uma comunidade em determinados espaço e época.

A par deste aludido bem jurídico, outras duas justificativas são ordinariamente elencadas para justificar o estatuto proibido dos escritos e objetos obscenos: $i$ ) a possibilidade do emprego de tais instrumentos para cultivar a prática de atos sexuais de modo descontrolado, excessivo ou desaprovado socialmente (fetichismos, masturbação), descambando para um aumento demográfico descontrolado, ou mesmo ii) uma suposta vinculação entre o consumo de pornografia e a insensibilidade masculina para limites de ordem sexual, transformando as mulheres em objetos de prazer e, diretamente, contribuindo para a prática de atos de violência sexual. ${ }^{140}$

vista 'esse bem social [o pudor público], formado pela média do pudor dos indivíduos que compõem a coletividade"”. DIX DA SILVA, Tadeu. Crimes sexuais..., ob. cit., p. 333.

139 DIX DA SILVA, Tadeu, ob. cit., p. 344. O autor faz menção a interessante exemplo trazido por HUNGRIA para diferenciar o âmbito de incidência desse tipo penal de acordo com a situação fática apresentada: se uma dada mulher exibir sua seminudez em uma praia quase desértica, no máximo, despertará a reprovação de alguns moralistas de plantão; se, de outro passo, a mesma mulher tiver o arrojo de exibir-se publicamente na Avenida Rio Branco, no centro movimentado do Rio de Janeiro, é provável que incorreria no tipo penal do artigo 233 do CP. Daí a diversidade de enfoques sendo levada em conta para fins de subsunção do fato à norma.

${ }^{140}$ Cf. SILVA, Marcelo Sarsur Lucas da. Obsceno, explícito: repensando a pornografia como problema jurídico-penal. Belo Horizonte: 2010. Conclusão da matéria "Temas de Direito Penal: O Corpo - Estudos" do curso de pós-graduação em Direito. Universidade Federal de Minas, p. 33. A questão de se encarar a mulher como objeto, em práticas pornográficas comerciais, vem sendo objeto de intenso debate entre o movimento feminista. 
No entanto, ambas as motivações não possuem substrato teórico ou empírico para serem sustentadas. Sim, pois no tocante ao primeiro argumento, uma suposta maior permissividade com relação ao consumo de material pornográfico em nada alterou os dados demográficos a ponto de ser um problema. Com isso, sobraria apenas o caráter moral de condenar a masturbação ou gostos sexuais não-convencionais.

De outra banda, a propalada relação entre exposição a obras pornográficas e estímulo da violência - ou insensibilidade ou fator de desagregação social, muito embora defendida por alguns detratores da pornografia (geralmente pessoas voltadas aos movimentos feministas) ${ }^{141}$, tampouco se verifica. A bem da verdade, é extremamente precário, ou simplista, tal raciocínio, já que não demonstra, com segurança, um vínculo causal direto entre o consumo desse tipo de material e atos de abuso ou violência contra a mulher.

Ademais, a respeito do caráter vago, genérico, desses tipos penais, pode ser defendida a ideia pela qual ambos os tipos penais em comento seriam inconstitucionais, visto que carentes de suporte mínimo que justifiquem a incriminação penal, ou seja, são tipos com expressões vagas e indeterminadas aponto de impossibilitar ao intérprete da norma o seu efetivo alcance. O particular não pode, nesse passo, ficar à mercê do Estado no tocante à configuração de um injusto penal.

Além do viés impreciso, convém lembrar que o artigo 78, parágrafo único, do Estatuto da Criança e do Adolescente já regulamenta a possibilidade de comercialização de publicações pornográficas, estabelecendo apenas que as capas daquele material devem ser dotadas de invólucro opaco.

Por esse motivo que TADEU DIX DA SILVA alerta para a existência de certa apreensão diante dessa característica fluida da noção de pudor público, já que tal figura penal busca resguardar um elemento de inevitável jaez moral, "o que não cabe amparo penal". E completa com a seguinte constatação diante da atual realidade em que vivemos: "por outro

\footnotetext{
${ }^{141}$ Relembre-se que há uma tendência, por parte de alguns pensadores, em invocar a "objetificação dos corpos" ou a "insensibilidade dos consumidores", ou mesmo a "degradação" do papel da mulher no meio da indústria pornográfica, conforme as palavras de SAMANTHA MEYER-PFLUG, (cf. nota 76).
} 
lado, ao homem normal não choca mais, como no passado, a exposição a obscenidades, particularmente quando a sexualidade tornou-se mais explorada, inclusive da perspectiva comercial e artística". ${ }^{142}$

Esse grau de incerteza quanto ao real alcance do conceito de "obsceno", quando falamos em aplicação do Direito Penal - que pode redundar na perda do direito de ir e vir do cidadão -, acaba gerando dúvidas a respeito de sua própria adequação ao princípio da estrita legalidade, colocando em risco a consequente legitimação.

A propósito, H.L.A. HART, ao comentar as consequências do julgamento de rumoroso precedente norte-americano conhecido como Caso Shaw ${ }^{143}$, menciona que os Tribunais poderiam funcionar como custos morum, ou como censores e guardiães gerais dos costumes", e que isso poderia resultar em alto preço a ser pago, com o sacrifício de garantias individuais conquistadas após árdua luta democráticas, para a institucionalização do Poder Judiciário no papel de críticos morais. E, segundo ele, "o valor particular mais sacrificado é o princípio da legalidade, que exige sejam as condutas delituosas definidas com a possível exatidão, de modo que se façam razoavelmente conhecidas, por prévia cominação, quais as ações tidas como puníveis e quais as consideradas penalmente lícitas ou indiferentes."144

Por isso é possível verificar que, de fato, a adoção do tipo penal demasiadamente aberto como no caso do ato obsceno acaba por colocar em sérios riscos a própria lisura do princípio da legalidade, já que, conforme destacado, o cidadão precisa saber a exata conduta inquinada de ilícita. Repita-se: o que é obsceno? O que pode ser considerado ilícito penal nesse âmbito tão restrito e subjetivo? A lei penal não o diz.

\footnotetext{
${ }^{142}$ Ob. cit., p. 244.

${ }^{143}$ Esse caso contempla a hipótese em que um editor foi acusado de diversos crimes (entre eles, publicar matéria obscena e induzir a corrupção da moral pública, além de favorecer a prostituição) porque foi o responsável pela composição e publicação de uma revista (Ladies Directory) fornecendo nomes e endereços de prostitutas, inclusive com fotos de algumas delas nuas. Os fatos se passaram em 1967. Apenas para se ter uma ideia do caráter moralista que marcou esse julgamento, veja-se a conclusão a que chegou um dos Juízes: tudo quanto seja contra bonos mores et decorum está proibido pelos princípios de nosso direito, e a Corte Real, como censora e guardiã geral da moralidade pública, está autorizada a conhecer e punir.” Ob. cit., p. 36.

${ }^{144}$ HART, Herbert L. A. Direito, liberdade, moralidade. Tradução de Gérson Pereira dos Santos. Porto Alegre: Fabris, 1987, p. 39.
} 
E isso, de acordo com o alerta de HART, apenas leva à perigosa conclusão de que virtualmente qualquer participação no delito pode ser tida como punível, se o órgão julgador a considerar ex post facto, como imoral. Ou seja, todo o plexo de considerações intelectuais de caráter libertário trazido por MILL, no sentido de se evitar demasiadas interferências e restrições à liberdade individual, estaria sob sério risco de violação. Em decorrência disso, o próprio desvirtuamento do direito penal sujeito às intempéries das conclusões judiciais poderia ser levantado pelas críticas, a nosso ver, pertinentes.

Nesse sentido, nota-se que essa prática comportamental atina muito mais com o âmbito de mera infração administrativa, sujeita a eventual multa, por exemplo, do que ensejadora da movimentação da máquina punitiva estatal. Com isso, percebe-se a evidente presença de obscuros elementos valorativos constantes do tipo, havendo afronta ao princípio basilar de qualquer Estado de Direito de evitar a índole difusa que, segundo DIX SILVA, "não permite uma divisão clara entre condutas proibidas e as atividades lícitas". ${ }^{145}$

No entanto, o aludido autor ressalta que essa fluidez provocaria uma aparente aporia, ensejando eventual risco de ser caracterizadas como criminosas condutas muito distintas entre si, em termos de ofensa ao senso estético: "se determinadas condutas abrigadas na fórmula vasta de ato obsceno não ostentam dignidade penal por se consistirem em comportamentos que lesionam o pudor público - uma noção de indubitável matiz moral -, outras ações que são contempladas nesse conceito pela doutrina e jurisprudência são merecedoras da tutela penal, visto que nitidamente maculam um bem jurídico dotado da devida concretude, a liberdade sexual." 146

E conclui seu raciocínio apresentando os perigos de uma revogação irrestrita do referido tipo, o que "deixaria ao desamparo a proteção da pessoa contra determinadas condutas que reclamam a tutela penal - como o ato de masturbar-se em frente de alguém ou de praticar

\footnotetext{
${ }^{145}$ Cf. DIX DA SILVA, Tadeu, ob. cit., p. 345.

${ }^{146}$ DIX DA SILVA, Tadeu, idem.
} 
relações sexuais perante um homem ou uma mulher - eis que vêm a ferir sua liberdade no âmbito da sexualidade."147

Por isso que, seguindo a tendência de ordenamentos penais europeus (Portugal, Espanha e Alemanha, para ficarmos nos exemplos mais contundentes), há de compartilhar a ideia de que deveria haver uma mudança do enfoque sobre a matéria, deslocando-se a reprovabilidade penal da esfera pública (senso comum, da moral coletiva) para a pessoal/individual, com a criação, a título de sugestão, de outra figura penal equiparada à do exibicionismo, presente, em diferentes amplitudes, naqueles países. ${ }^{148}$

Decorre daí o afastamento de qualquer ingerência da assim chamada moralidade sexual quando o assunto é a definição do delito equivalente ao exibicionismo. A propósito, seguindo proposta de lege ferenda de DIX DA SILVA, o ideal seria pensar na construção de uma figura criminosa autônoma, diferenciada da atual noção de ato obsceno, na busca de se alcançar comportamentos que se revestissem de maior gravidade e em que fossem atrelados à ideia de proteção da liberdade sexual do indivíduo. Em contrapartida, ficariam excluídos do injusto penal todo e qualquer elemento indicativo da moralidade pública.

\footnotetext{
${ }^{147}$ Ob. cit., idem.

148 O mesmo DIX DA SILVA ressalva que os tipos penais de exibicionismo não ficou isento de críticas doutrinárias, por diferentes motivos, nos países em que foi prevista tal figura delituosa. Após revelar que o crime definido no direito espanhol alude à tutela de menores de quatorze anos, e que, em Portugal, não apresenta essa delimitação etária, ao passe que o CP germânico prevê o tipo básico de exibicionismo praticado perante qualquer indivíduo e a versão derivada que menciona o resultado do ato de "provocar um escândalo público", explica o autor: "na Espanha se questiona o 'relativismo que acompanha a noção de atos de exibicionismo', onde setores da doutrina veem como autor apenas a pessoa 'geralmente com problemas de desequilíbrio mental, que realiza atos de exibição de seus órgãos genitais a um estranho'. Mesmo porque a concepção de 'atos exibicionistas' permite que se divise, inclusive, que 'a expressão exibição não possui nenhuma acepção de ordem sexual (...). A polêmica cerca também o tipo penal português, quando se coloca em questão a própria formulação legal, eis que 'o texto do artigo não sugere qualquer restrição quanto aos atos de caráter exibicionista', o que leva à posição doutrinária para que se faça 'uma interpretação restritiva', que reconheça enquanto típicos 'tão-só atos exibicionistas relacionados com a sexualidade'. O tipo penal alemão, de sua feita, pode ser discutido (...): trata-se de um preceito vago e ambíguo, na sua forma básica, e na derivada ostentas uma duvidosa tutela de 'interesses públicos', que se avizinham temerariamente de uma faixa fronteiriça do campo das 'moralidades' e a do interesse público - onde se vislumbram, neste caso específico, ecos de acepções morais interligadas à noção de pudor público". Ob. cit., p. 346-347. Diante disso, é possível enxergar a imposição, por parte da doutrina, de limites quando da caracterização do tipo penal, buscando-se afastar os critérios perigosos do pudor comum que impera em uma sociedade. $\mathrm{O}$ caráter vago de ato obsceno também aparece nos tipos de exibicionismo.
} 
Por isso, por exemplo, apenas seriam objeto de proteção apenas aquelas pessoas que se deparassem com alguém mantendo relações sexuais ou masturbando-se em via pública (ou mesmo na esfera privada, desde que sem o consentimento dos atingidos), afastando-se do âmbito de incidência do injusto penal outras condutas menos lesivas, deixando-as ao crivo da esfera administrativa.

O importante, nesses casos, seria evitar que alguém se sentisse importunado, sendo imprescindível que o ato exibicionista ocorresse perante a vítima, e, por óbvio, sem a sua aceitação ou concordância com tal proceder. O delito, nessa hipótese, teria nítida natureza de perigo concreto, sempre se tendo em vista a tutela da liberdade sexual de terceiros, no sentido de se evitar uma posterior eventual investida do agente contra os espectadores de tal ato (liberdade negativa). Nesse quadro, o espírito da norma penal é justamente o de proteger, além da autodeterminação da vítima (de modo indireto), o seu direito de não ser importunada na sua própria privacidade. ${ }^{149}$

É bastante provável que, diante de uma novel figura delitiva equiparada ao crime de exibicionismo ${ }^{150}$, nos moldes já apresentados, o duvidoso caráter inconstitucional do atual artigo 233 do Código Penal brasileiro restaria superado. ${ }^{151}$

Sim, pois, ao focar o direito individual da autodeterminação da pessoa atingida pela ação exibicionista - e, em decorrência, também o direito de autoconformação de sua vontade $^{152}$-, acaba sendo extirpado do sistema jurídico o ranço de moralismo legislativo ainda presente no Código Penal brasileiro em pleno século XXI.

\footnotetext{
${ }^{149}$ Essas sugestões legislativas foram elencadas por TADEU DIX DA SILVA, ob. cit., p. 349.

${ }^{150}$ Aproveitando, uma vez mais, a sugestão engendrada por TADEU DIX DA SILVA, poderíamos pensar em um tipo penal com uma interessante redação próxima da seguinte: "Atos de exibicionismo: art. (...) Importunar outra pessoa, praticando perante ela, e sem sua aceitação, qualquer tipo de relação sexual ou então o ato de masturbarse ou de exibir os órgãos genitais”. (ob. cit., p. 351).

${ }^{151}$ Afinal, com relação ao delito de ato obsceno, na sua redação vigente, também são aplicáveis, a nosso ver, as mesmas críticas estrangeiras no tocante à sua duvidosa recepção pelo texto constitucional de 1988, haja vista a fluidez do conceito de "obsceno".

${ }^{152}$ A doutrina mencionada a expressão privacy-dignity para definir o alcance desse direito subjetivo violado pelos atos exibicionistas (cf. TADEU DIX DA SILVA, ob. cit., p. 348).
} 
Aliás, não é por outra razão que o Anteprojeto de Código Penal brasileiro, decorrente dos estudos realizados por Comissão presidida pelo Ministro do Superior Tribunal de Justiça GILSON DIPP - formada, ainda, por diversos juristas e operadores do Direito $^{153}$-, encaminhado para escrutínio do Senado Federal em agosto de 2012, propõe a revogação integral dos tipos fixados nos artigos 233 e 234 do Código penal atual.

Com efeito, da leitura do Anteprojeto, na parte que trata dos delitos contra a liberdade sexual, prefaciada por LUIZA NAGIB ELUF, podem ser destacadas algumas considerações acerca do novo contexto social a respeito dos delitos desse jaez, que levaram à descriminalização de vários tipos penais considerados obsoletos.

Com o título "Crimes contra a liberdade sexual: atualização, revogação $e$ criminalização”, a aludida Procuradora de Justiça traça a seguinte argumentação acerca das mudanças legislativas nessa área: "poucos títulos do Código Penal se mostram tão defasados em face das práticas e necessidades de proteção social atuais como o dos crimes contra a dignidade sexual. ${ }^{154}$ Embora o texto de 1940 tenha recebido modificações pontuais, elas não foram suficientes para honrar o nome atual do título - crimes contra a dignidade sexual - permanecendo, como sombra, o nome antigo, talvez mais revelador da ideologia de tipificação ali encontrada: crimes contra os costumes. A proposta da Comissão,

\footnotetext{
${ }^{153}$ Batizado de "Projeto Sarney", em alusão ao atual Presidente do Senado Federal, o texto final do Anteprojeto não ficou isento de severas críticas por parte de alguns setores especializados na área criminal. Apesar de alguns avanços, como a apontada descriminalização do tipo de ato obsceno, diversos outros dispositivos deixam antever claro retrocesso punitivo. Cumpre lembrar que a forma como foi instalada a Comissão, a rapidez dos trabalhos e estudos (cerca de sete meses de atividade) e a falta de amplos debates populares sobre mudanças tão drásticas e significativas no sistema penal foram os principais motivos que levaram até à realização de um ato público de repúdio ao Anteprojeto, no dia 24 de setembro de 2012, no salão nobre da Faculdade de Direito da Universidade de São Paulo. Intitulado “Ato em defesa do Direito Penal: crítica ao projeto Sarney”, o movimento foi subscrito por diversas entidades de destaque no universo jurídico-penal, tais como a AASP (Associação dos Advogados de São Paulo), o IBCCRIM (Instituto Brasileiro de Ciências Criminais), a Defensoria Pública de São Paulo, o IDDD (Instituto de Defesa do Direito de Defesa), a APMP (Associação dos Procuradores do Município de São Paulo), a OAB paulista, o Centro Acadêmico XI de Agosto, entre outras.

${ }^{154}$ Nesse ponto, convém uma breve crítica: muito embora tenha havido mudança do título a respeito dos crimes sexuais, tal modificação não chegou a alterar o contexto jurídico do tema. Isso porque, segundo LUÍS AUGUSTO SANZO BRODT, em artigo intitulado "Dos crimes contra a dignidade sexual: a nova maquiagem da velha senhora", o autor, citando o trabalho de HELENA REGINA LOBO DA COSTA sobre o tema "dignidade humana", ressalta que "a própria expressão 'dignidade da pessoa humana', que estaria a dar suporte à 'dignidade sexual, apresenta conteúdo bastante controverso,o que pode acarretar sérios inconvenientes em matéria de segurança jurídica. Helena Regina Lobo da Costa alerta para 'o perigo de o princípio se tornar um Cavalo de Troia, a permitir a entrada das mais diferentes visões de mundo no sistema constitucional." Em Revista de Ciências Penais 2010, RCP 13, p. 172.
} 
portanto, é fortemente descriminalizadora, propondo a supressão dos crimes de 'violação mediante fraude', art. 215, 'mediação para satisfazer a lascívia de outrem', art. 227, 'casa de prostituição', art. 229, 'rufianismo', art. 230, 'ato obsceno', do art. 233 e 'escrito ou objeto obsceno', art. 234."155

Como se vê, o espírito da reforma é justamente afastar, extirpar do sistema toda e qualquer alusão aos ditames moralistas presentes na redação original de 1940. Daí porque não haver mais sentido a manutenção de tipos penais como os ora comentados. Veja-se, inclusive, que o teor do novo texto dá um passo adiante quanto à proposta de criação do delito de exibicionismo, o que pode ser encarado como demonstração, ao menos nesse ponto, de claro avanço democrático no tocante à disciplina penal da liberdade sexual.

Caso seja aprovado pelo Congresso nacional, após tramitação em ambas as Casas legislativas, se não for objeto de emendas nesse particular, o novo Código Penal, com certeza, deixará para trás o critério pudor público como legitimador de tipos penais meramente simbólicos, significando uma tomada de posição condizente com o atual contexto social.

Assim, pode-se imaginar, em uma perspectiva otimista, que a revogação dos atuais artigos 233 e 234 do $\mathrm{CP}$ poderia trazer mais luzes às discussões a respeito de delitos relacionados com a pornografia infantil (tanto a real quanto a virtual), o que será objeto de nosso estudo, na medida em que, repise-se, haverá uma saudável mudança de enfoque, privilegiando-se a autodeterminação e a liberdade sexuais. Diante dessa nova perspectiva, o Direito Penal se ocupará, apenas e tão-somente de comportamentos efetivamente lesivos a esses bens jurídicos de jaez individual, deixando fora do espectro de incidência penal condutas que atentem contra a moralidade pública.

Aqui, porém, há um alerta necessário: como já dito, caso os tipos penais em comento sejam, de fato, revogados, seria aconselhável a criação de uma figura criminosa intermediária, que abarcasse a hipótese daquele que, por exemplo, se exiba, desnudo, na presença de crianças, bem como, do indivíduo que se masturbe em local de acesso público. Por isso, a

\footnotetext{
${ }^{155}$ Disponível em: http://s.conjur.com.br/dl/anteprojeto-codigo-penal.pdf (pág. 321 - destaques meus).
} 
introdução de um tipo semelhante ao do exibicionismo seria mais condizente com a ausência de critérios meramente morais, de um lado, e a necessidade de uma proteção mínima daquelas pessoas que não queiram deparar-se com alguém praticando esse tipo de conduta libidinosa.

Sim, pois nessas hipóteses mais extremas, o contato visual de crianças e adolescentes com atos desse jaez pode significar, além do constrangimento inerente à própria situação, uma violação à incolumidade sexual desse peculiar grupo de pessoas ainda em formação. Daí porque a previsão delituosa da conduta de exibir-se em público, mediante comportamento sexual explícito, seria capaz de tutelar os mesmos interesses que a atual redação dos tipos em comento busca, em vão, proteger.

De qualquer modo, cabe lembrar que outro fator que reforça a falta de sentido da própria existência desses tipos penais (ato obsceno e escrito obsceno) repousa na afronta ao direto à intimidade do cidadão, configurando a criminalização desse tipo de conduta inaceitável viés paternalista no uso do direito penal.

Conforme já salientado anteriormente, a esfera de autonomia do indivíduo não pode ser violada com a previsão de uma sanção de natureza criminal no tocante ao acesso a matérias de cunho pornográfico ou obsceno, claro, por óbvio, desde que respeitado o princípio da autodeterminação e capacidade, conforme será analisado em detalhes mais adiante.

Ainda que não se considerem contrários ao texto constitucional, é preciso ressaltar a possibilidade de aplicação do princípio da adequação social, segundo o qual somente há de se falar em tipicidade material do injusto penal quando a conduta for reprovável sob o conjunto de valores culturais de determinada época.

Assim, por exemplo, desde há muito é tolerado (e, mais, aceito) o fato de se comercializar revistas e filmes de cunho pornográfico, ou até mesmo a dança levada a cabo por strippers em casas noturnas, circunstâncias que nem de longe poderiam justificar a aplicação da lei penal. 
Cabe dizer, repise-se, que não deixa de ser uma incongruência que a sociedade, em seu atual estágio evolutivo, aceite e tolere as produções pornográficas de um lado, e, de outro, ainda exista a previsão dessas figuras delituosas em nosso ordenamento jurídico ainda em vigor.

Por isso que, no cômputo geral, os tipos legais em comento são incompatíveis com um direito penal voltado a fins político-criminais e à tutela de interesses essenciais ao funcionamento da sociedade, tanto que, se aprovado o Projeto de Código Penal, será extirpado do sistema brasileiro em boa hora. 


\section{CAPÍTULO 4 - Os crimes sexuais e os menores}

Como aproximação ao tema da pornografia infantil, é preciso observar a forma como o Direito Penal vem disciplinando a sexualidade de crianças e adolescentes, até porque será de extrema utilidade para as questões relativas ao consentimento ou à capacidade de autodeterminação desse peculiar grupo de indivíduos.

Esse breve capítulo se iniciará por meio de um exame acerca dos critérios relacionados com a chamada "liberdade sexual" e seus desdobramentos.

\subsection{Liberdade sexual}

O estudo dos denominados crimes sexuais e o posterior desenrolar do raciocínio a ser construído sobre a questão do enfoque jurídico-penal sobre os problemas relacionados com a pornografia infantil, requer alguns conceitos jurídicos e de cunho político-criminal, que serão fundamentais para o objeto deste trabalho. Entre eles, sem dúvida, o termo liberdade sexual desponta com extrema valia e necessário destaque.

As premissas básicas intrínsecas ao assim chamado Direito penal sexual dependem, por suposto, da verificação e da aplicação do instituto em questão, a fim de delinear até que ponto o Estado estará legitimado a interferir em matéria tão íntima aos membros da sociedade.

A compreensão do significado de liberdade sexual traduz-se na pretensão de que toda pessoa exerça a atividade sexual em liberdade, isto é, é faculdade do ser humano de determinar-se autonomamente no âmbito sexual.

O sentido e o alcance do conceito de liberdade sexual, segundo KARL NATSCHERADEZ, deita raízes no estabelecimento das relações entre o Direito Penal e a 
chamada "moral social", estabelecendo-se os limites da intervenção penal, devendo ser afastados do seu espectro de incidência os valores ético-sociais para, em seguida, delinear a posição sobre qual deve ser o bem jurídico tutelado nessa área da sexualidade.

Sempre tendo em vista um viés constitucional, o autor pontua os pressupostos sobre os quais está assentada a definição do objeto de proteção do denominado Direito Penal Sexual: a) apenas com a existência de um dano efetivo é que o controle estatal está autorizado a ser exercido, de modo que a mera imoralidade ou o afastamento dos padrões estabelecidos pelo senso comum não se confunde com tal ideia; b) inexiste um consenso sobre quais condutas sexuais teriam relevância jurídico-penal, ainda mais se levarmos em conta a enorme variedade de comportamentos possíveis nesse campo; c) a ausência de uma valoração global da sexualidade socialmente compartilhada, em uma sociedade plural e diversificada, não representa qualquer risco à convivência social, tornando legítimas as várias expressões da sexualidade, entendida como uma das premissas básicas à autorrealização humana. ${ }^{156}$

Diante de tais considerações, conclui-se que a finalidade do Direito Penal sexual constitui na tentativa de garantir a liberdade mais elástica possível nas relações sexuais, apenas cabendo falar em relevância penal, com criminalização de condutas, nos casos em que ditos comportamentos configurarem um grave dano à autodeterminação das pessoas nesse âmbito restrito. $^{157}$

Feitos esses esclarecimentos introdutórios, é importante destacar que existem, nesse plano, duas vertentes da liberdade sexual: a dinâmica (ou positiva) ${ }^{158}$ e a estática (também tida

\footnotetext{
${ }^{156}$ NATSCHERADETZ, Karl Prelhaz. O direito penal sexual: conteúdo e limites. Coimbra: Almedina, 1985, p. 139.

${ }^{157}$ Talvez por esse motivo sejam tão atuais as ponderações de JOHN RAWLS, citada por Gerson Pereira dos Santos na introdução à obra de HART, no sentido de que "quando se disse, por exemplo, que certos tipos de relações sexuais são degradantes e vergonhosos, e deveriam ser proibidos sob tal pretexto, é frequentemente porque uma razoável argumentação não pode ser apresentada em termos de princípios de justiça." (A theory of justice, 11. ${ }^{\text {a }}$ Ed., 1981, p. 331, apud HART, H.L.A., Direito, liberdade..., p. 21).

${ }_{158}$ MARIA DO CARMO DA SILVA DIAS faz uso da expressão tolerância positiva para designar a mesma ideia aqui tratada. No seu entender, "não pode haver intervenção do direito penal em relação aos comportamentos daqueles que, livremente, mas sempre sem ingerência nos direitos de terceiros, adoptam posturas sexuais consideradas 'incorrectas' pelo sistema social." E arremata a jurista portuguesa, que "quando essas condutas 'sexualmente incorrectas' ocorrem, de forma consentida, na esfera privada, não é posta em causa a estabilidade da sociedade, ainda que sejam violadas normas sociais." Crimes sexuais..., ob. cit., p. 208. Explicando melhor, não se nega a
} 
como negativa ${ }^{159}$, sendo possível falar, ademais, numa terceira, considerada mista, conciliando os aspectos marcantes de cada uma dessas figuras.

A primeira (dinâmica) encerra a livre disposição do próprio corpo com objetivo de saciar a lascívia, respeitando-se a esfera de cada um, segundo seus próprios desejos, dentro dos parâmetros do mútuo consentimento e do respeito à sexualidade alheia. Aqui, devemos entender o direito à livre disposição tanto no concernente à forma de manifestação como também ao destinatário de tais condutas.

Com efeito, o alcance da vertente positiva da liberdade sexual repousa na acepção segundo a qual o exercício de tal liberdade acaba sendo a expressão da concreta autonomia da pessoa, consubstanciando naquele terreno onde é defeso ao legislador criminalizar algumas maneiras de proceder que não atinjam bens fundamentais de terceiros.

Em outras palavras, "atenta a natureza do bem jurídico em causa, apenas o respectivo portador individual (isto é, o portador concreto) - no pleno gozo da sua capacidade de autodeterminação - pode dispor livremente da sua sexualidade e exercê-la, mesmo que de forma 'irracional', quando, com quem e como quiser, mas sempre sem prejuízo dos direitos de terceiros." 160

A dimensão positiva há de ser entendida, em suma, como a garantia conferida a cada pessoa de interagir sexualmente sem restrições, desde que não haja, conforme já dito, colisão com direitos de terceiros, mormente no tocante ao consentimento (elemento volitivo).

eventual afronta a padrões ditados pela "coletividade" ou pelas ideologias dominantes que dado comportamento possa provocar. O que importa, nessas hipóteses, é afastar a ingerência do Estado, mais precisamente o uso da força legítima consubstanciada pela ameaça ao direito de ir e vir do indivíduo, quando se está a tratar de universo tão diversificado como o da sexualidade humana.

${ }^{159}$ MANUEL DA COSTA ANDRADE sintetiza a definição de liberdade sexual no sentido negativo como sendo o direito de "resistir a imposições não queridas". Consentimento..., ob. cit., p. 395.

${ }^{160}$ DIAS, Maria do Carmo..., ob. cit., p. 209. Por óbvio a questão da ofensa a terceiros será retomada quando, no momento próprio, abordarmos os reflexos da liberdade sexual daqueles que adquiram ou possuam material pornográfico envolvendo menores. De todo modo, para fins de delimitação dos bens jurídicos atinentes ao Direito Penal sexual, a ideia de liberdade positiva deve ter uma função de guia (amparo) fundamental ao legislador nesse seara, tudo para se rechaçar incriminações indevidas e/ou abusivas. 
Já a acepção estática compreende o direito a rechaçar toda e qualquer importunação de terceiros no tocante à prática de atos sexuais. A autodeterminação da pessoa, sob esse aspecto, guarda relação com a garantia de que cada um possui o direito de não sofrer qualquer espécie de invasão ou intromissão, física ou psicológica, dirigida à atividade sexual. ${ }^{161}$

Não se pode esquecer que, do ponto de vista político-criminal, a noção negativa da liberdade sexual deve levar em conta, quando falamos de incriminação de condutas, os princípios da fragmentariedade e subsidiariedade do Direito Penal, criminalizando-se apenas comportamentos que possuam efetiva capacidade de violar o consentimento do ofendido (ameaça ou violência).

Por outra banda, a concepção mista (ou integradora) entende que a liberdade sexual merece ser analisada sob ambas as vertentes, consistente na noção de que a livre disposição do corpo cabe ao próprio indivíduo, bem como a possibilidade de se acionar os meios protetores da função sexual em detrimento das condutas de terceiros da mesma natureza. ${ }^{162}$

Com relação ao aspecto positivo (ou dinâmico) da autodeterminação sexual, não há dúvidas acerca do benefício de tal garantia à sociedade, à medida que a liberdade sexual é inerente à autoconformação da vida das pessoas e assume grande relevância em uma vivência plural, pois a sexualidade é um dos mais relevantes domínios da vida dos indivíduos e possibilita-lhes a realização plena como ser humano. ${ }^{163}$

\footnotetext{
${ }^{161}$ Explicando melhor essa posição, de acordo com Alessandra Greco e João Daniel Rassi, parafraseando a já citada obra de NATSCHERADETZ, o caráter positivo do conceito"se concretiza na faculdade que o indivíduo tem de não suportar de outrem a realização de atos de natureza sexual contra sua vontade, qualquer que seja a forma que eles revistam, 'embora o entendimento do direito penal como ultima ratio implique que apenas seja tutelada a liberdade sexual contra acções que revistam de uma certa gravidade." Crimes contra a dignidade..., ob. cit., p. 61 .

${ }^{162}$ Os aspectos dinâmico e estático não são, a princípio, excludentes, senão integradores, residindo aí a expressão "acepção integradora", utilizada por José M. SANCHES TOMAS. Apud GRECO, Alessandra; RASSI, João..., ob. cit., p. 61, nota 164. MARIA DO CARMO DA SILVA DIAS, ao discorrer sobre o caráter misto de ambas as vertentes, chega à interessante conclusão de que "estas duas vias de análise da liberdade sexual, são complementares e essenciais na concretização e na definição do bem jurídico tipicamente protegido, que desta forma ganha autonomia no confronto com outros bens jurídicos de índole pessoal." Crimes sexuais..., ob. cit., p. 210.

${ }^{163}$ SILVA, Tadeu..., ob. cit., p. 71.
} 
Aliás, repita-se, esse alcance do conceito de liberdade sexual coaduna-se com a proposição político-criminal pela qual não pode ser considerada criminosa a conduta travada entre pessoas capazes, respeitado o elemento volitivo, na esfera privada, de modo que tal noção é marca de um Estado de Direito laico.

Nessa ordem de ideias, as conclusões a que chegou NATSCHERADETZ, sem dúvida, vão de encontro à tese que reduz o conceito de liberdade sexual (disposição do próprio corpo) a um aspecto relativo aos bons costumes. Isso porque, tomar como aceitável esse tipo de limitação seria dar guarida ao raciocínio pelo qual a proteção dos standarts sociais nessa seara se justificaria, reavivando o ultrapassado conceito de pudor público, algo inadmissível em uma vivência pluralista.

De acordo com o alertado por MARIA DO CARMO DIAS, o legislador deve, sempre que possível, ter cautela quando sopesar as vertentes negativa e positiva da liberdade sexual, a fim de se evitar a imposição de programas de controle sexual, com a aniquilação do direito à livre disposição do corpo de indivíduos capazes e autodeterminados.

Ao identificar uma tendência na criminalização de condutas atreladas ao viés negativo da liberdade sexual, pontua a autora portuguesa que "protege-se penalmente em princípio o caráter negativo - porque mais carecido de protecção - mas, o legislador deve ter o cuidado de, ao maximizar a tutela do bem jurídico por essa via (negativa), não acabar por limitar ou restringir de forma excessiva a liberdade sexual na sua dimensão positiva."164

Daí porque necessária, por esse viés, a introdução do elemento gravidade no exame do bem jurídico tutelado nesse particular, justamente para evitar ao máximo a incriminação de comportamentos sexuais irrelevantes ou insignificantes, ao menos diante da gama de condutas possíveis em tão larga atividade humana (sexualidade).

Em outras palavras, admitir juízos de valor, de cunho fluido e subjetivo, quanto à determinação da gravidade de certa conduta sexual em relação ao interesse específico que a lei

\footnotetext{
${ }^{164}$ Ob. cit., p. 210.
} 
busca proteger levaria ao indevido reconhecimento da necessidade de tutelar uma moral sexual coletiva, fato que atentaria à própria liberdade sexual sob um aspecto individual.

Ao lado disso, convém lembrar que a liberdade sexual deve ser tida como um dos corolários da liberdade pessoal lato sensu, como sendo uma liberdade geral de ação ou o direito ao livre desenvolvimento da personalidade, que, em último grau, é um desdobramento da própria ideia de dignidade da pessoa humana.

Nessa ordem de ideias, surge com evidente destaque a necessidade de "neutralização" do prisma pelo qual o direito penal sexual deve atuar, buscando evitar a imposição de dadas condutas sexuais. ${ }^{165}$

\subsection{Crimes sexuais e vítimas menores ou incapazes}

Nas hipóteses em que o ofendido de qualquer delito de natureza sexual seja criança ou adolescente - no Brasil, como se sabe, nos moldes estabelecidos pelo artigo $2 .^{\circ}$ do ECA, criança é a pessoa com até doze anos de idade incompletos e adolescente é aquele entre doze e dezoito anos -, a sistemática de proteção especial da infância e juventude reclama um peculiar tratamento.

Sim, pois as diversas variáveis sobre a melhor maneira de equacionar a tutela de garantias de um livre e saudável desenvolvimento em todos os aspectos e o respeito à própria personalidade dessas pessoas (principalmente dos adolescentes) em um contexto social tão liberal - apesar das já citadas correntes conservadoras ou reacionárias - em que vivemos acabam apresentando um rol de situações problemáticas que merece ser enfocado. Afinal,

\footnotetext{
${ }^{165}$ Bem por isso as legislações de vários países, após as reformas de cunho liberal das últimas décadas, buscou alijar do conceito de bem jurídico nessa seara os resquícios machistas, sexistas ou homofóbicos. Esse foi o caldo de cultura, por exemplo, que acabou por extirpar alguns elementos normativos (v.g., "mulher honesta" ou "mulher virgem" de alguns tipos penais). Tudo em busca da efetivação de uma sociedade diversificada, complexa, porém laica e democrática, calcada no respeito aos ditames constitucionais (principalmente, nos princípios da igualdade e da proporcionalidade).
} 
quando será salutar a aplicação da lei penal no tocante a práticas de natureza sexual consentidas pelo menor? Aliás, é possível afirmar-se a existência de "capacidade" sexual de infantes?

Além disso, também é preciso examinar quais os bens jurídicos em lume quando se fala em sexualidade infanto-juvenil, até para sabermos se, em pleno século XXI, a forma de disciplinar essas hipóteses é condizente com o avanço cultural verificado nos dias que correm.

\subsubsection{O bem jurídico tutelado: é possível falar em liberdade/capacidade sexual de menores?}

Em primeiro lugar, pela análise mais detida sobre os vetores decorrentes do conceito de liberdade sexual, existe uma diferenciação entre os denominados crimes contra a liberdade/dignidade sexual e os delitos sexuais praticados contra menores ou incapazes.

Com efeito, com relação à vítima menor de crime sexual, fica patente que, nesse tipo de prática delitiva, o desvalor das condutas realizadas deve ser considerado em relação à precocidade do ato sexual na medida em que é idôneo a prejudicar o normal desenvolvimento e a maturação da personalidade do menor, sob o aspecto da sexualidade. ${ }^{166}$

Consoante o entendimento de diversos setores doutrinários, quando se fala sobre a "liberdade sexual dos menores", visto que ainda não se pode concluir pela existência de uma autodeterminação em razão das peculiaridades dessa classe de indivíduos ${ }^{167}$, temos de ter em mente a proteção do sadio desenvolvimento dessa sexualidade.

\footnotetext{
${ }^{166}$ FRANCO, Alberto Silva. Crimes contra os Costumes. Em: FRANCO, Alberto Silva; STOCCO, Rui (org.). Código penal e sua interpretação jurisprudencial, vol. II. Parte Especial. São Paulo: RT, 2001, p. 3060.

167 Principalmente no tocante à imaturidade ou falta de experiência de vida dessa parcela da população. A propósito desse tema, destaca-se, sobre os chamados atos sexuais de relevo, que "a 'maturidade', de facto, não pode ser desligada do contexto social em que se exerce. (...) Em outras palavras, para densificar o conceito de actos sexuais de relevo é necessário recorrer às 'concepções sociais dominantes' ou, nas palavras de Teresa Beleza, a uma cláusula de 'adequação social'. São estas que, em última análise, dão relevo - relevo sexual - a um acto que, em si mesmo, representa apenas um contacto corporal." ARAÚJO, António de. Crimes sexuais contra menores... entre o Direito Penal e a Constituição. Coimbra: Coimbra Editora, 2005, p. 156-157.
} 
Por isso, nesse particular, pode-se trabalhar com a ideia de liberdade sexual 'in fieri', ou seja, liberdade sexual futura da criança ou adolescente que se pretende proteger pela tutela penal, para que, no futuro, tais indivíduos possam adquirir maturidade e, livres de qualquer interferência indevida, desfrutar de uma autodeterminação realmente livre no campo da sexualidade. ${ }^{168}$

Ou seja, haveria um deslocamento no tempo da liberdade sexual dos menores e incapazes, sendo garantia de crianças e adolescentes que a lei penal assegure o seu crescimento equilibrado sob o perfil da sexualidade, para que possa exercitar, mais adiante, a sua liberdade sexual, despida de quaisquer traumas ou danos psicológicos tão presentes nos atentados dessa natureza. ${ }^{169}$

Ainda nessa seara, convém lembrar o pensamento crítico de MARTHA DE TOLEDO MACHADO, no sentido de que a invocação dessa liberdade futura seria insuficiente para justificar, por si só, a intervenção do Direito Penal sexual relativo ao universo infanto-juvenil, pois “como o Direito Penal (...) precisa centrar-se nas lesões a direitos fundamentais do ser

168 Cf. DIX SILVA, Tadeu. Crimes sexuais..., p. 237. Refratária a essa ideia, MARTHA DE TOLEDO MACHADO, ao ressaltar o caráter de mera ficção jurídica desse bem jurídico invocado, destaca que "a ficção jurídica, embutida na identificação do bem jurídico penal com a liberdade sexual futura, esconde a real dimensão da lesividade específica do fato sexual precoce de relevo, contra a criança (e também contra o adolescente), porque ela reduz a lesão efetiva ao plano do 'desenvolvimento na esfera da sexualidade'. Mas a lesão efetiva atinge o desenvolvimento da personalidade infanto-juvenil em todas as suas facetas (físico, psíquico, moral, cognitivo, social etc.), e não exclusivamente ao 'desenvolvimento na esfera da sexualidade'. A lesão é sempre atual (...) para esse ser humano uno e atual (...), ainda que essa lesão efetiva também traga em seu bojo lesão diferida no tempo, sob o ângulo as potencialidades do ser humano adulto. (...) Essa noção fictícia da liberdade sexual futura reduz a criança e o adolescente a um 'adulto em miniatura', protegendo-os não em razão da pessoa que já é; mas sim por aquilo que, no futuro, se concebe que poderia ser." MACHADO, Martha de Toledo. Proibições de excesso e proteção insuficiente no processo penal: as hipóteses de crimes sexuais contra a criança. São Paulo: Verbatim, 2008, p. 222. Depois de atentar ao fato de que, quando se trata de adolescentes, estes já têm em boa medida liberdade sexual estrito senso (quanto mais próximo do fim da adolescência, mais essa medida se amplia), sendo inexato falar em "liberdade futura" quanto a eles, a mesma autora completa o raciocínio afirmando que, ao não se fazer diferenciação entre criança (até doze anos) e adolescentes (dos treze aos dezoito anos), "a categoria teórica da liberdade sexual futura abre-se à possibilidade de interpretações moralistas ou à proteção legal desmedida, tanto quanto a vítima é criança, como quando é adolescente.” (grifos do original).

169 Ainda sobre a aparente incongruência entre as noções de liberdade sexual e autodeterminação do menor (que sequer possui discernimento válido sob o ângulo da legislação), convém mencionar interessante proposta de TADEU ANTÔNIO DIX SILVA no sentido de se operar um deslocamento topográfico dos crimes desse jaez no texto do Código Penal: "Em consonância com esse entendimento, os delitos praticados contra menores necessariamente devem ser incluídos no título referente aos 'Crimes contra a Integridade Psíquica' denominação de um novo agrupamento de delitos a se criar e que possuem como bem jurídico a integridade psíquica da pessoa". Crimes sexuais..., p. 72 (destaques nossos). 
humano que tenham relevo ético-jurídico suficiente para justificar os custos (individuais e sociais) da sanção criminal, parece-me que focar a tutela penal na integridade física e moral da criança favorece bem mais a própria efetividade das garantias conectadas à proibição de excesso, do que a categoria jurídica da liberdade futura ficta, ainda que esta última categoria, histórica e teoricamente, tenha representado enorme avanço democrático em relação à categoria a ela anteriormente vigente, qual seja a de que a tutela penal vinha em proteção da moralidade pública ou dos costumes." 170

Os perigos de, com a tutela da vertente negativa da liberdade sexual se estar sacrificando exageradamente a vertente positiva dessa mesma liberdade do portador individual do bem jurídico, podem surgir em áreas como designadamente as relativas à proteção dos menores, atenta a complexidade do valor que se pretende proteger e dados os riscos de se poder querer ver, nessas normas, também, a proteção, ainda que secundária ou reflexa, de bens supra-individuais.

De fato, o legislador não pode sugerir nem pretender impor modelos educativos, mais ou menos controladores da sexualidade dos menores, sob pena de estar a subverter bem jurídico da autodeterminação sexual que pretende tutelar, além de estar a contrariar o programa político-criminal a que aderiu. Por isso, a imposição ou oferta de qualquer modelo de educação sexual terá de ser feita através de adequados meios de controle social e não através do direito penal. ${ }^{171}$

A imaturidade inerente aos menores de certa idade acarreta, como consequência natural, uma particular vulnerabilidade, a justificar uma proteção específica e adicional, complementar da que é dada ao adulto que esteja no pleno gozo das suas capacidades.

É que o exercício da liberdade sexual pressupõe e depende antes de tudo da plena capacidade de autodeterminação sexual. E é essa capacidade da autodeterminação que deve ser salvaguardada, de forma que, quando atingida a sua plenitude, o jovem -

\footnotetext{
${ }^{170}$ Ob. cit., p. 224, grifos do original.

${ }^{171}$ DIAS, Maria do Carmo, ob. cit., p. 211.
} 
independentemente do sexo, possa exercer por si só o direito de exprimir-se sexualmente em liberdade. ${ }^{172}$

O bem jurídico protegido, nessas hipóteses, é o bem-estar psíquico do menor e do incapaz, interesse este que abrange o direito de obter um adequado processo de formação, compreendido como um interesse primordial dos sujeitos individuais envolvidos, e que surge antes da compreensão (da própria consciência) do fenômeno da sexualidade. A ideia aqui é salvaguardar o desenrolar livre da construção psicológica dos menores, vedando-se ingerências estranhas aos seus interesses.

A lei teve, então, de estabelecer critérios etários a fim de observar a partir de que idade os menores seriam considerados capazes de se autodeterminar sexualmente, funcionando como elemento básico de tipificação de condutas sexuais ilícitas. Diante da dificuldade de se estabelecer em que fase a maturidade do menor pode ser avaliada, NATSCHERADEZT destaca que "em lugar da característica material determinante constituída pela imaturidade sexual, nos tipos legais de crimes de proteção da juventude se coloque um limite geral fornecido pela idade do jovem". ${ }^{173}$

Tanto isso é verdade que, ao discorrer sobre os crimes contra a autodeterminação sexual no CP português ${ }^{174}$, JOSÉ MOURAZ LOPES chama a atenção para os parâmetros a serem observados pelo Direito Penal sexual aplicado aos menores, de modo que, com a criminalização das referidas condutas, não se pretende proteger um padrão de comportamentos sexuais ou resguardar algum grupo de pessoas em particular, mas sim tutelar e salvaguardar uma vontade individual, ainda insuficientemente desenvolvida e apenas parcialmente livre das ofensas que sobre ela executa o agente criminoso, aproveitando-se da imaturidade do jovem

\footnotetext{
${ }^{172}$ DIAS, Mario do Carmo. Ob. cit., p. 215. Aliás, cabe destacar que "o fim específico é proteger os menores de condutas que atentem ou possam colocar em grave perigo 'o livre desenvolvimento da sua personalidade', aqui especialmente no que respeita à área penal".

${ }^{173}$ GRECO, Alessandra..., ob. cit., p. 71.

${ }^{174}$ Somente para exemplificar, no subtítulo II - 'Dos crimes contra a autodeterminação sexual', estão dispostas algumas figuras delitivas envolvendo menores: abuso sexual de crianças (artigo 172..$^{\circ}$ ), abuso sexual de adolescentes e dependentes (artigo $173 .^{\circ}$ ), ato homossexuais com menores (artigo $175 .^{\circ}$ ) e lenocínio de menores (artigo 176. ${ }^{\circ}$ ).
} 
com relação à sua sexualidade ainda em formação. ${ }^{175}$

O ponto crucial quando tentamos identificar a existência (ou não) de uma liberdade sexual (ou de autodeterminação) relacionada aos menores é, a nosso sentir, encarar os jovens, no contexto de estratosférico avanço tecnológico nesse início do século XXI, como cidadãos ainda em desenvolvimento, porém sujeitos de poder descobrir as próprias sensações, saciar a curiosidade de maneira sadia e compatível com parâmetros mínimos de dignidade da pessoa humana.

Afinal de contas, as perturbações fisiológicas e/ou psicológicas resultantes de uma iniciação sexual muito precoce ${ }^{176}$ consubstanciam fatos e fatores suficientes a fim de lastrear uma proteção jurídica nos moldes acima expostos, desde que tais comportamentos, analisados em cada caso concreto, representem uma efetiva interferência no desenrolar da evolução saudável da sexualidade desse grupo tão peculiar de cidadãos.

No entanto, é preciso lembrar que nem todo e qualquer ato sexual realizado com menores deverá ser considerado ofensivo ao bem jurídico tutelado pela norma, já que certos contatos entre jovens não serão caracterizados como abuso ou exploração. Nessas hipóteses, entende-se, inclusive, que determinadas experiências erotizadas fazem parte do próprio processo de descobrimento do corpo desses adolescentes, sendo benéficas para o seu crescimento sexual, devendo, por isso, ser excluídas do âmbito de incidência da proteção penal. $^{177}$

A propósito, não podemos ignorar outro dado empírico relevante para a maneira de se encarar a sexualidade dos menores: no mundo hodierno, na chamada sociedade da velocidade

\footnotetext{
${ }^{175}$ LOPES, José Mouraz. Os crimes contra a liberdade e autodeterminação sexual no Código Penal. $4 .^{\mathrm{a}}$ ed. Coimbra: Coimbra Editora, 2008, p. 16. O mesmo autor completa seu raciocínio trazendo ainda mais elementos para se compreender qual interesse é tutelado com a proibição de determinados tipos de relações sexuais travadas com menores: "reconhece-se implicitamente o direito á sexualidade como direito a proteger e tutelar, no âmbito do direito à liberdade individual, mas também o direito à proteção da sexualidade numa fase inicial ou em desenvolvimento, que, pelas suas características, é carecida de tutela jurídica." Ob. cit., idem.

${ }^{176}$ Ainda que não envolva violência física ou moral e mesmo que haja 'consentimento' do menor (podendo ser este último claramente viciado ou irrelevante aos olhos do Direito Penal sexual).

${ }^{177}$ Esse alerta foi levantado por KARL NATSCHERADETZ, na já citada obra O direito penal sexual: conteúdo e limites..., p. 204.
} 
da informação, o desenvolvimento da autoconsciência sexual aparece cada vez mais cedo, comparativamente com outros tempos. ${ }^{178}$

De fato, segundo pesquisa realizada pela Academia Norte-americana de Pediatras, o início da adolescência - do ponto de vista do crescimento corporal e do surgimento dos chamados caracteres sexuais secundários (alterações pilosas, mudanças de voz, por exemplo) - ocorre atualmente em fase muito mais precoce do que no passado, sobretudo no caso das moças (dez/treze anos nas meninas; onze/catorze anos nos rapazes). Nesse contexto, mudou a possibilidade real de um rapaz ou de uma garota iniciarem novas formas de relação física e afetiva. ${ }^{179}$

Essa pesquisa não está isolada. De acordo com STELLA REGINA ARQUETE, “tem sido observado nos últimos cinquenta anos um aumento dramático na atividade sexual na adolescência (...). A té o início deste século, casava-se para formar um lar e lançar as bases de uma realidade social nitidamente definida. Não existia uma relação direta entre amor e casamento. A partir da década de 30 começou a haver algumas mudanças. $\mathrm{O}$ amor passou a ser valorizado sob todos os aspectos, principalmente o sexual, ainda que a sexualidade continuasse vinculada à procriação. Porém a opinião pública mostrava-se mais tolerante em relação à sexualidade pré-nupcial, desde que os noivos se amassem e quisessem levar uma vida a dois, mas continuava a reprovar as mães solteiras. Os costumes, aos poucos, vão se modificando, a contracepção feminina se generaliza e a sexualidade se dissocia da procriação". ${ }^{180}$

E continua a autora, ressaltando que a idade da primeira relação sexual vem

\footnotetext{
${ }^{178}$ Nesse quadro fático, basta obervar que, em um mundo digital, tal precocidade acaba sendo reflexo da rapidez e facilidade na obtenção de informações, bem como, do próprio estímulo advindo dos meios de comunicação (mormente TV e revistas/jornais), que, sem qualquer pudor, favorecem e até incentivam a exploração da sexualidade em todos os níveis.

${ }^{179}$ Segundo os dados levantados pela pesquisa, em um intervalo de uma década (entre 1983 e 1993), a iniciação sexual desse grupo de pessoas vem acontecendo cada vez mais precocemente, sendo um sinal dos tempos. ARAÚJO, António de. Crimes sexuais contra menores..., ob. cit., p. 117.

${ }^{180}$ ARQUETE, Stella Regina. Iniciação sexual da adolescente. O desejo, o afeto e as normas sociais. Tese de Doutorado apresentada ao Departamento de Pediatria da Faculdade de Medicina da USP, para a obtenção do título de Doutora em Pediatria. Ribeirão Preto, 1997, p. 13. (Disponível em http://www.nesa.uerj.br/download/TESE_STELLA.pdf).
} 
diminuindo no decorrer dos anos. Entre 1938 e 1950 aproximadamente $7 \%$ das mulheres brancas nos EUA tinham atividade sexual aos dezesseis anos (Kinsey, 1948). Em 1960, 20\% dos homens e $12 \%$ das mulheres de 15 a 19 anos tinham atividade sexual. Na década de 70 esse percentual subiu para 55\% para os homens e 46\% para as mulheres (Strasburger, 1985b; Curtis et al., 1988). Setenta por cento dos jovens americanos aos dezoito anos já tiveram relações sexuais e metade deles não usa anticoncepção. (Montgomery, 1976; Freeman et al., 1980; Klein \& McAnarney, 1993). A iniciação sexual na adolescência funciona como um rito de passagem da infância para a idade adulta. Muitas são as razões relatadas pelos adolescentes para iniciar o sexo: curiosidade, urgência física, pressão grupal, prova de amor ao parceiro, expressão de rebelião parental, social ou religiosa." 181

Observam-se, assim, duas tendências que, mesmo não sendo totalmente contraditórias, exigem maior coerência no tratamento jurídico da realidade juvenil: de um lado, uma inquestionável sexualização precoce, quer do ponto de vista físico quer psicológico, à qual não pode ficar indiferente, conforme já dito, o acesso rápido e irrestrito à informação e a maior exposição dos menores a mensagens de conteúdo sexual ${ }^{182}$; de outra banda, uma

\footnotetext{
181Completa a autora: "ainda seguindo a mesma linha, Netting (1992) realizou uma pesquisa entre estudantes canadenses sobre comportamento sexual, em 1980 e repetiu-a em 1990. Foi aplicado um questionário em 118 estudantes em 1980 e em 314 em 1990, no mesmo local. Os resultados dos questionários foram comparados e analisados estatisticamente. A principal mudança da década foi a diminuição da virgindade feminina, que baixou de $41 \%$ para $21 \%$. Entre os estudantes sexualmente ativos, a média de idade do primeiro intercurso não mudou: aproximadamente 16 anos para os homens e 17 anos para as mulheres. Essa pesquisa, entretanto, não explica quais os fatores envolvidos na diminuição da virgindade feminina nesta década.” (ob. cit., p. 15-16).

${ }^{182}$ MARSHA LEVICK, advogada americana, cofundadora, Conselheira e Diretora do "Juvenile Law Center" traz à luz uma prática recorrente entre adolescentes em busca pela descoberta de sua sexualidade, o que demonstra uma radical mudança de paradigmas no mundo contemporâneo: um fenômeno chamado sexting. Aliados à tecnologia que nossa época proporciona, os jovens exploram sua sexualidade mediante o intercâmbio de fotos e mensagens privadas e em tempo real. Por meio de pesquisas, foi possível conferir que aproximadamente $20 \%$ dos adolescentes americanos já aderiram ao sexting. Segundo a autora, não poderia ser diferente, já que a tecnologia está infiltrada no comportamento adolescente. Utilizam-se dela para expressar-se quanto a diversos temas relacionados ao cotidiano, como frustrações com os pais ou a escola, entusiasmo com os amigos, ou até mesmo para desenvolver amizades ou relacionamentos com parceiros. Desta forma, à medida que se tornam gradualmente conscientes de sua sexualidade, muitas vezes sentem a necessidade de compartilhar informações sobre suas experiências com os outros. Assim, de acordo com LEVICK, pretender enquadrar esse tipo de conduta nas pesadas leis penais relativas à pornografia infantil (o que será abordado mais à frente), permitindo-se a persecução penal de jovens e adolescentes, abusando de sua discricionariedade ao invés de considerar alternativas para dirimir a questão (LEVICK, Martha. Prosecuting sexting as child pornography, disponível em http://scholar.valpo.edu/vulr/vol44/iss4/2, acessado em 12 de outubro de 2012). Claro que esse fenômeno marcante da "geração digital" mereceria uma análise mais aprofundada, podendo ser objeto de trabalho próprio, o que escaparia do alcance da presente monografia. De toda forma, aparece com inegável relevância a maneira como os jovens vêm usando os meios tecnológicos para descobrirem a sexualidade e os relacionamentos amorosos.
} 
crescente dificuldade de adaptação dos jovens aos desafios da sociedade contemporânea.

Tudo isso, por óbvio, deve ser sopesado pelos operadores do Direito, de modo que os especialistas vêm aconselhando, ao menos sob o aspecto clínico, o alargamento das barreiras temporais da adolescência. Por isso, sob nossa óptica, a cautela deve ser levada em conta quando se fala em (falta de) consentimento de menores quanto a atos sexuais. ${ }^{183}$

É preciso alertar, contudo, que a iniciação cada vez mais precoce da vida sexual de adolescentes não significa afirmar que tal circunstância equivale a um início sempre saudável do desenvolvimento da maturidade sexual dessas pessoas, sob pena de incidir em perigosa (e injusta) generalização. Isso porque existem aqueles casos em que, independentemente do grau de vivência ou experiência sexual de jovens, pode ocorrer a prática de atos sexuais violentos, configurando uma iniciação indesejada no mundo da sexualidade, podendo até provocar traumas e prejuízos psicológicos irreparáveis a esses futuros adultos. De qualquer forma, quando são focados os critérios aplicáveis à questão dos delitos de pornografia infantil (quando e como punir essas condutas), esses dados empíricos devem sempre ser levados em conta, visto que não é aconselhável fechar os olhos à inegável precocidade sexual de adolescentes e jovens.

No caso brasileiro, assim como no exemplo português, foi estabelecida a idade-limite de catorze anos, abaixo da qual se presume (absolutamente) como prejudicial todo e qualquer contato de natureza sexual, sendo inferido que tal proceder prejudica gravemente o livre

\footnotetext{
183 Ainda sobre a sexualidade infanto-juvenil, é preciso diferenciar comportamentos que, muito embora objetivamente possam caracterizar à primeira vista algum ato sexual de relevo (para se utilizar expressão própria do Direito Penal sexual português), na realidade não ostentam qualquer necessidade de tutela penal, por fazer parte de um contexto de afeto ou carinho. Parafraseando MARTHA DE TOLEDO MACHADO, "juridicamente, o beijo nas nádegas de adolescente externa, no mundo realístico, a inequívoca intenção lasciva do agente; o beijo nas nádegas de um bebê de seis meses, dado pela mãe, pela avó, pelo pai, por si mesmo nada externa no mundo fenomênico, exceto o afeto natural dos familiares próximos da criancinha." (ob. cit., p. 224). Ou seja, é preciso cuidado para se distinguir algumas condutas, a fim de se evitar uma perigosa generalização, sempre tendo em mente as circunstâncias concretas, até porque, conforme constatação da mesma autora, "particularmente a cultura brasileira, em que o contato físico entre as pessoas, socialmente não tem a conotação erótica que tem em outros países. Tanto assim que, nas famílias e nas escolas, as crianças de pouca idade, quando praticam agressão física contra o irmão ou o coleguinha, são estimuladas por pais e professores, não apenas a desculpar-se, mas também a externar afeto para como agredido, beijando-o" (ob. cit., p. 224, nota 6).
} 
desenvolvimento da personalidade. ${ }^{184}$

Ainda sobre a abrangência da chamada "liberdade sexual" dos menores, vale apontar dois aspectos comumente invocados para o exame jurídico da questão: $i$ ) a interpretação de que menores e incapazes (enfermos, por exemplo) gozam de liberdade sexual, porém a lei presume, de forma absoluta, que eles não estão facultados a exercê-la, tratando-se de clara ficção jurídica; e ii) compreender que ditos indivíduos não dispõem de liberdade sexual, à exata medida que é pressuposto da liberdade uma determinada capacidade de conhecimento e vontade, traços de personalidade de que eles ainda não desfrutam em razão da situação objetiva em que se encontram, não sendo, pois, este o interesse jurídico protegido, senão a intangibilidade sexual. ${ }^{185}$

Nessa esteira, os efeitos práticos de ambas as formas de pensar acabam sendo os mesmos, isto é, menores não ostentam essa liberdade seja porque valorativamente não podem tê-la, ou seja, porque normativamente criou-se tal opção.

De qualquer modo, sob qualquer ângulo que se examine a questão, levando-se em conta os critérios de igualdade trazidos pelo texto constitucional, seria incongruente diferenciar jovens e adultos no tocante ao livre exercício da sexualidade. O ideal, então, será valorar a capacidade cognitiva daquelas pessoas em grau de desvantagem (por causa de sua situação peculiar), evitando-se que tais jovens possam ser objeto de abuso por terceiros, garantindo-se o direito à descoberta (sadia) da sexualidade.

O consentimento de crianças e adolescentes (posição diferenciada) deve ser considerado válido, desde que respeitados certos limites e circunstâncias, avaliadas caso a caso. Isto porque as limitações da liberdade sexual de menores "só são possíveis quando

\footnotetext{
${ }^{184}$ DIAS, Maria do Carmo...Ob. cit., p. 215, nota 398.

${ }^{185}$ GRECO, Alessandra..., ob. cit., p. 73. Ainda acerca desse tópico, ANTÓNIO DE ARAÚJO, ao examinar a disciplina jurídica que diferencia os efeitos penais da manutenção de relações de natureza hétero e homossexuais com menores, utiliza interessante expressão para tal distinção: "a questão não se relaciona com eventuais "efeitos traumáticos', como já se afirmou por diversas vezes, mas com a ausência de interferências externas suscpetíveis de prejudicarem o processo formativo da sexualidade. Não se trata de paternalismo, mas de proteger a 'autonomia dos menos autónomos' (...) impedindo que a expressão da sexualidade do adolescente seja intersectada por elementos espúrios e perturbadores. Para que, no fundo, a sexualidade constitua uma efectiva realização da autonomia pessoal.” Ob. cit., p. 158 (destaques meus).
} 
suponham um ataque à sua dignidade ou ao seu livre desenvolvimento, e isso não pode ser valorado de uma forma genérica ou calcada em meras ilações" ${ }^{186}$, como se depreende da presunção absoluta (juris et de iure) decorrente da norma legal limitadora.

Aliás, a título de sugestão, parece que o ideal seria flexibilizar o sistema de responsabilidade penal nessa seara do direito sexual, afastando a atual rigidez legal e estabelecendo critérios objetivos bem definidos a fim de apurar a partir de qual patamar é possível falar em liberdade sexual de um indivíduo.

Assim, por exemplo, até os doze anos (e não os atuais catorze anos, conforme o art. 217-A do CP), haveria ausência absoluta de liberdade sexual; dos doze aos dezoito anos, poder-se-ia pensar em uma noção de liberdade sexual relativa (ou incompleta), na qual o adolescente ainda teria uma proteção da lei penal para os casos em que fosse verificado claro abuso de sua ingenuidade ou imaturidade ${ }^{187}$; e a partir dos dezoito anos, a liberdade seria integral, podendo a pessoa dispor de seu corpo como melhor lhe aprouver - sem prejuízo, claro, da incidência da lei penal em casos de constrangimento, violência ou grave ameaça, configurando o crime de estupro (artigo 213 do CP).

Com isso, a consideração gradativa da liberdade sexual trairia mais lógica ao sistema, buscando conciliar, de um lado, os ditames da integral proteção ao ser em desenvolvimento, e, de outro, evitar ao máximo sancionar penalmente indivíduos envolvidos em contexto sexual consentido com jovens muitas vezes com considerável vivência no tema.

O mais importante, a nosso sentir, consiste em afastar os critérios moralistas dos exames das situações concretas, tendo em mente a realidade atual, em que os adolescentes são bombardeados por estímulos audiovisuais de cunho sensual ou erótico, o que é aceito pelos padrões sociais.

\footnotetext{
${ }^{186}$ SANCHES TOMAS, Jose M. Los abusos sexuales en el Código Penal de 1995: em especial sobre o menor de doce años y abusando de transtorno mental. Cuadernos de Política Criminal. Madri: Edersa, 1997, v. 61, p. 112.

${ }^{187}$ Poderia ficar a critério do Magistrado a observação pontual do reconhecimento (ou não) da liberdade sexual nesses casos localizados na zona cinzenta (entre os doze e dezoito anos de idade).
} 


\subsection{A vulnerabilidade dos menores}

A questão do conceito de vulnerabilidade, aplicado ao chamado Direito Penal Sexual, e seus desdobramentos dogmáticos, sem sombra de dúvidas, representa tópico útil para a posterior compreensão e análise jurídico-penal dos ilícitos relacionados à pornografia infantil. Por isso, serão despendias apenas algumas rápidas palavras sobre o tema.

Em realidade, o ordenamento jurídico sempre considerou a relevância da especial condição da pessoa em desenvolvimento no tocante a comportamentos criminosos na seara da sexualidade desses indivíduos.

JANAINA CONCEIÇÃO PASCHOAL, em artigo no qual se faz uma atual análise crítica a respeito de polêmica levantada pela ampla divulgação pela mídia brasileira de alguns precedentes jurisprudenciais sobre o assunto ${ }^{188}$, apresenta as premissas sobre as quais repousa o conceito da vulnerabilidade do menor nos crimes sexuais de forma mais ampla.

Após pontuar a criação de um novo tipo penal, operado pela reforma da parte especial do Código Penal dedicada aos crimes sexuais ${ }^{189}$, em que a idade da vítima veio a fazer parte ínsita ao próprio elemento do injusto, sem qualquer menção à violência (real ou tácita/presumida) ${ }^{190}$, a autora prossegue sua análise trazendo uma noção mais abrangente da ideia de vulnerabilidade/carência dos menores, em um contexto de exploração sexual.

\footnotetext{
${ }^{188}$ PASCHOAL, Janaina Conceição. O consumo de prostituição infantil já é crime no Brasil. Boletim IBCCRIM. São Paulo: IBCCRIM, ano 20, n. 236, p. 02-03, jul., 2012. O julgado que funcionou como estopim dessa

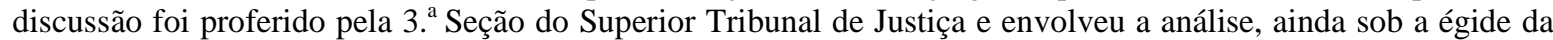
lei antiga (antes, pois, da reforma de 2009), afastando-se a presunção de violência por causa da "experiência" de adolescentes de treze anos de idade, com as quais o agente manteve relações sexuais consentidas.

${ }^{189}$ Cuida-se do denominado estupro de vulnerável, previsto pelo artigo 217-A do Código Penal, com a redação dada pela Lei 12.105/09: “Art. 217-A "Ter conjunção carnal ou praticar outro ato libidinoso com menor de 14 (catorze) anos. Pena - reclusão, de 8 (oito) a 15 (quinze) anos. $\S 1^{\circ}$ Incorre na mesma pena quem pratica as ações descritas no caput com alguém que, por enfermidade ou deficiência mental, não tem o necessário discernimento para a prática do ato, ou que, por qualquer outra causa, não pode oferecer resistência."

${ }^{190}$ Há um aspecto destacado pela mencionada penalista que merece realce, diante da provável problemática casuísta quando da aplicação da nova figura delitiva: percebe-se uma inevitável equiparação, geral e abstrata, entre condutas de diferenças abissais em termos de reprovabilidade, e colocando em risco o critério de
} 
Com efeito, rebatendo aqueles que entenderam justificada a interpretação pela qual se afastou a tipicidade do estupro apenas porque as vítimas seriam "iniciadas" na prática da prostituição, "surpreende a ideia de que o estupro de vulnerável não seria aplicável à pessoa que utiliza os serviços da criança prostituída, pois, no caso da prostituição infantil, está-se diante de várias fontes de vulnerabilidade: idade, carência econômica, desestrutura familiar". 191

Isso é verificado, pois, ainda que possa ser objeto de críticas, o legislador reconhece como passível de tutela a salvaguarda do interesse do menor de catorze anos em ver-se livre de quaisquer contatos lascivos ou libidinosos até tal idade-limite, deixando subentendido o reconhecimento de que essas pessoas ainda não teriam maturidade suficiente para dispor do próprio corpo. ${ }^{192}$

Ademais, ainda no campo da integração da tenra idade da vítima ao próprio tipo penal criado - a princípio, sem qualquer possibilidade de flexibilização interpretativa -, significativo segmento doutrinário deixou assentada a solução de eventuais disparidades na resposta ao seguinte questionamento: cabe falar, nos dias atuais, em vulnerabilidade relativa no âmbito dos crimes contra a dignidade sexual? ${ }^{193}$

Ainda nos dizeres de ISRAEL JORIO, a despeito da expressa previsão legal, não seria possível uma análise dissociada dos elementos circunstanciais verificados no caso concreto, sob pena de desrespeito ao princípio da ofensividade. Esse autor faz um apanhado das razões

proporcionalidade norteador do Direito Penal. (ob. cit., p. 2) V.g., estaria configurado, em tese, o crime tanto na hipótese de o agente realizar apalpadelas na coxa de uma menor prestes a completar catorze anos até no caso em que alguém pratique coito anal ou vaginal com uma criança de tenra idade (cinco anos, por exemplo). Aqui, o perigo de igualar comportamentos flagrantemente distintos acaba revelando o preço a ser pago pela escolha do legislador quando da mudança da lei, cabendo à jurisprudência, ao nosso entender, aparar tais disparidades, segundo a casuística. Esse exame será retomado um pouco mais adiante nesse mesmo capítulo.

${ }^{191}$ Ob. cit., p. 3.

192 Ainda de acordo com essa posição, o real escopo do ordenamento jurídico repousaria sobre a necessidade de se evitar a "coisificação" e/ou a "comercialização" desse indivíduo que ostenta a condição especial de ser em desenvolvimento.

${ }^{193}$ JORIO, Israel Domingos. Vulnerabilidade relativa, sim! In Boletim IBCCRIM. São Paulo: IBCCRIM, ano 20, n. 236, p. 08-09, jul., 2012. 
de cunho político-criminal para afastar o caráter absoluto dessa presunção, apresentando um panorama bastante crítico em relação ao engessamento trazido pela nova lei:

“O Poder Legislativo, no ano de 2009, deu-nos sua opinião. Não importa se há casos e casos. Não importa se a prática desmente a teoria. Se a ficção suplanta a realidade. Sexo com pessoas menores de 14 anos, independentemente dos atributos pessoais dos envolvidos e das relações afetivas que porventura existam, é inexoravelmente criminoso. Nesse contexto, se um jovem de 18 anos namorar com uma adolescente de 13 cometerá crime hediondo (se matá-la, não necessariamente). O pior é que a atitude foi desleal. Aparentemente, por não se falar mais em presunção de violência, não haveria mais o que se relativizar." 194

Lastreado em critérios de ofensividade (lesividade), o mesmo autor advoga a tese de que quando a noção de vulnerabilidade é flexibilizada, deve reconhecer que o consentimento, naquele particular caso, pode ser considerado válido. É irrelevante a supressão da presunção de violência, porque a razão da 'presunção de vulnerabilidade' é a mesma. Se existe consentimento, e se ele é válido, desfaz-se por completo a noção de ofensa à dignidade sexual. Cuida-se de um comportamento formalmente típico (previsto no art. 217-A do CP), mas materialmente atípico (isto é, que não significa ataque real ao bem jurídico tutelado). ${ }^{195}$

Ou seja, se antes da mudança do Código Penal, tanto doutrina e jurisprudência desde há muito vinham relativizando o conceito de violência presumida aos casos em que as vítimas de delitos sexuais ostentavam menos de catorze anos, o novo texto legal, na contramão desse entendimento, não só estabeleceu uma vulnerabilidade dissociada dos critérios de vulnerabilidade "real" (social), como ainda aumentou a pena mínima do delito para oito anos de reclusão.

\footnotetext{
194 Ob. cit., p. 8.

195 Ob. cit., p. 9.
} 
Diante disso, a nosso sentir, o legislador perdeu uma ótima oportunidade de flexibilizar a posição anterior, já que poderia ter deixado a cargo do Judiciário definir, caso a caso e diante das peculiaridades concretas, se houve (ou não) violação da liberdade do menor.

A propósito, cabe mais uma vez mencionar a existência de proposta de modificação do referido dispositivo penal que trata do estupro de vulnerável (artigo 217-A do CP) no corpo do Anteprojeto de Código Penal ("Projeto Sarney”), prestes a ser votado pelo Congresso Nacional, que propõe a redução da idade-limite para os doze anos de idade, além de adicionar a figura da "molestamento sexual de vulnerável". 196

Segundo a exposição de motivos da proposta, nesse ponto assinada por LUIZA NAGIB ELUF, os critérios de política criminal devem levar à necessária diminuição etária para a configuração da vulnerabilidade, diante do avanço cultural observado no mundo contemporâneo, bem como pela própria definição de criança constante do Estatuto de Crianças e Adolescentes (a pessoa que tenha até doze anos de idade, e não catorze anos). O sistema ficaria mais lógico, acompanhando as circunstâncias empíricas e o padrão já fixado pela legislação especial - ECA. ${ }^{197}$

No tocante a essa modificação, não há como negar que, caso aprovada, toda a celeuma e as infindáveis discussões doutrinárias e jurisprudenciais a respeito do caráter absoluto ou relativo da presunção de violência para fins de caracterização da vulnerabilidade seriam inúteis e ultrapassadas. Aí, a nosso ver, o projeto andou bem em diminuir a idade-limite para os doze anos, de modo que o novo critério etário, mais condizente com tudo o que abordado

\footnotetext{
196 Segundo a nova redação proposta, assim ficariam os tipo penais aplicáveis à matéria: "Estupro de vulnerável. Art. 186. Manter relação sexual vaginal, anal ou oral com pessoa que tenha até doze anos. Pena prisão, de oito a doze anos. (...) Molestamento sexual de vulnerável. Constranger alguém que tenha até doze anos à prática de ato libidinoso diverso do estupro vaginal, anal ou oral. Pena - prisão, de quatro a oito anos." Disponível em: http://s.conjur.com.br/dl/anteprojeto-codigo-penal.pdf (p. 324-325). Parece adequada a introdução do até aqui inédito crime de molestamento sexual, que consubstancia espécie intermediária entre o ato mais grave (estupro) e o menos danoso ('importunação do pudor alheio', mera contravenção penal), figurando como um terceiro delito, com rigor e punição mais condizentes com as circunstâncias fáticas (quatro a oito anos de prisão).

${ }^{197}$ De acordo com os termos da proposta, destacando a imperiosidade de adequação da previsão legal aos ditames da sociedade atual, "a Comissão entendeu apropriado acompanhar o critério estabelecido pelo ECA que considera criança o ser humano até doze anos de idade. Além disso, é comum que pré-adolescentes iniciem a vida afetiva aos treze anos, o que coloca o direito penal atual defasado em relação às alterações de comportamento". Disponível em: http://s.conjur.com.br/dl/anteprojeto-codigo-penal.pdf (p. 324).
} 
até agora, viria ao encontro da implementação de um sistema mais razoável, afastando o caráter criminoso de relações sexuais consentidas entre pré-adolescentes.

Assim, qualquer relação sexual praticada com crianças - menores de doze anos (mesmo "consentida") ostentaria caráter ilícito, havendo a incidência da lei penal, considerando tal grupo de pessoas com o rótulo inescapável de "vulneráveis", juntamente com os enfermos e deficientes mentais. 


\section{Capítulo 5 - PORNOGRAFIA INFANTIL}

Nesse capítulo reside o núcleo central do trabalho, qual seja, a análise de tipos penais relativos à disciplina legal de proteção de crianças e adolescentes à luz dos critérios até aqui delineados.

Uma vez apresentadas as relações entre Direito e Moral, o paternalismo jurídico-penal, a aproximação da matéria com a questão do obsceno e dos crimes sexuais envolvendo crianças e adolescentes, é necessário um exame detido da problemática intrínseca à disciplina penal da pornografia infantil.

Para tanto, a busca, na doutrina nacional e estrangeira, dos fundamentos da incriminação da posse de material pornográfico, de natureza real e virtual, será vital para descobrir, $i$ ) se, realmente, tal conduta pode ser considerada como "ofensiva aos interesses do jovem em desenvolvimento"; ii) se o comportamento estaria, ou não, no âmbito da esfera inviolável acima mencionado; iii) se a invocação de dados genéricos de repressão às "redes de pornografia" seriam realmente legítimas e pertinentes no atual sistema jurídico brasileiro; $i v$ ) se os critérios de ofensividade/lesividade poderiam ajudar na elaboração das conclusões.

Uma relevante distinção é necessária: com relação à posse de pornografia infantil real - na qual houve, de fato, uma ofensa concreta a um menor impúbere -, dúvidas persistirão se seriam aplicáveis os princípios da exclusiva proteção de bens jurídicos e da esfera inviolável de autonomia. Agora, no que concerne à simulação desse tipo de material, a incriminação aparece como sendo abusiva e incondizente com os ditames constitucionais.

O debate do assunto em questão revela considerável complexidade na parte relativa aos eventuais limites impostos ao legislador na exata delimitação - e definição - de condutas que mereçam a etiqueta de crime. 
$\mathrm{Na}$ busca do exato alcance da chamada pornografia infantil, será preciso relacionar os critérios de política criminal, de limitação ao uso (e abuso) do Direito Penal com a proteção à plena liberdade sexual da criança e do adolescente (ou autodeterminação sexual) - liberdade esta compreendida como o direito a que o menor de dezoito anos tem de descobrir e exercer a sua sexualidade sem qualquer interferência deletéria de adultos.

Em um primeiro momento, é indispensável a verificação da definição de material pornográfico infantil. Impende partir da adoção de um conceito objetivo de pornografia infantil, sem referência a valores morais ou religiosos, para só então se adentrar ao que poderá ser objeto de eventual incriminação.

Existe certa dificuldade em distanciar de critérios subjetivos ou meramente valorativos para perceber o que deva ser, ou não, considerado pornografia infantil. Segundo os dizeres de INÊS FERREIRA LEITE, de uma forma geral, tal conceito englobaria qualquer representação, por qualquer meio, de uma criança no exercício de atos sexuais explícitos, reais ou simulados, ou qualquer representação dos órgãos sexuais de uma criança para fins eminentemente libidinosos. ${ }^{198}$

Outras definições constantes do Direito Comparado serão apresentadas, mas o traço comum entre elas repousa em alguns pontos: representação de condutas sexuais explícitas, e/ou representativas, de órgãos genitais; a falta de qualquer finalidade ou cunho artístico ou científico e a possibilidade de elaborar representações gráficas, escritas ou de áudio.

Com a definição do que poderia ser considerado pornografia infantil, resta saber se existem elementos concretos que possam demonstrar se haveria alguma ligação ou relação entre o consumo desse tipo de material e a prática de atos de violência ou desrespeito à autodeterminação sexual de crianças e adolescentes.

\footnotetext{
${ }^{198}$ LEITE,..., ob. cit., p. 54.
} 


\subsection{O conceito de pornografia infantil}

Há dificuldades imanentes para determinar, em primeiro lugar, que significado atribuir ao conceito de material pornográfico e, de outro, como esclarecer o quê se deve entender por “infantil”. São expressões polissêmicas, que não estariam informadas por critérios comuns aos países, havendo diferenças entre o emaranhado legislativo internacional. ${ }^{199}$

Sob o olhar da doutrina especializada, o alcance do conceito de obsceno - para fins de caracterização de pornografia como conceito de relevância penal - deve estar atrelado à real destinação de dito material. Só se poderá falar na elaboração de pornografia infantil quando houver nítido caráter lascivo, provocativo, instigativo, voltado ao exclusivo escopo de estímulo da libido das pessoas destinatárias desses documentos.

O entendimento da doutrina a respeito do objeto dos crimes relacionados com material pornográfico infantil leva em conta duas vertentes: a positiva (representação gráfica, sonora e/ou escrita que contenha o fim precípuo da excitação sexual de seu observador) e a negativa (a ausência de valores estéticos, informativos ou científicos). Por isso que, parafraseando DIEZ RIPOLLES:

"Debe entenderse por representación pornográfica toda aquella que posea una tendencia objetivada de excitar sexualmente y que, además, resulte apta de modo general para involucrar intensamente a las personas que entren en contacto con ella en un contexto sexual.

Tal definición consta de dos partes: En la primera de ellas se atiende a la finalidad objetivada en la propia representación, a lo que da sentido a toda su materialidad y a todo el contenido intelectual, sensorial y afectivo que lleva incorporado, a su significación esencial, que no debe identificarse, ni con la finalidad del autor o creador material de ella, ni con las potencialidades o aptitudes que pueda tener la

\footnotetext{
${ }^{199}$ Para ter uma ideia do pluralismo legislativo, existem distinções sobre tais conceitos até entre Estados norteamericanos, o que reforça ainda mais as dificuldades acerca de como enquadrar as condutas tidas como delituosas.
} 
representación en sí para lograr tal finalidad objetivada. A su vez esta tendencia objetivada se concreta en la finalidad de excitar sexualmente, finalidad o función que le impregna por completo.

La segunda parte de la definición tiene la misión de introducir la referencia a la gravedad o magnitud en el propio concepto de objeto pornográfico, ya que sólo así éste adquiere su plena configuración, y se hace adoptando el mismo punto de referencia, coherente con el bien jurídico protegido, que hemos elegido para configurar el elemento de la gravedad de la conducta en los actos lúbricos y de exhibición obscena". 200

Especificamente sobre a conduta de elaboração de escritos - aqui incluídos, por exemplo, desenhos, quadrinhos e textos -, o entendimento dominante continua sendo o de que, estando presentes o objetivo de excitação sexual e, ausentes quaisquer finalidades outras (educativa, informativa, científica, artística), tais materiais também se encaixam no conceito de material pornográfico.

Ainda a respeito do efetivo alcance da noção de pornografia infantil, é preciso que o teor de tal material tenha, ao menos potencialmente, idoneidade para ofender o livre desenvolvimento do menor. Cuida-se de interpretação um pouco mais restritiva (ou limitadora) do espectro de incidência da norma neste particular. Afinal, deve-se ter em mente que o material pornográfico deve, de alguma maneira, ser idôneo para produzir algum tipo de dano ao desenvolvimento da personalidade de pessoas imaturas ou incapazes de controlar seus instintos. $^{201}$

Vale traçar um paralelo entre o entendimento doutrinário e a jurisprudência irradiada pela Suprema Corte norte-americana, cujas diretrizes, no mais das vezes, servem de ponto de partida para o objeto de nosso estudo.

200 DÍEZ RIPOLLÉS, J.L.: "Las últimas reformas en el Derecho penal sexual”, en Estudios Penales y Criminológicos, XIV, 1991, págs. 90 y 91.

${ }^{201}$ BERENGER, Enrique Orts; TORRES, Margarita Roig. Concepto de material pornográfico en el ámbito penal. ReCRIM: Revista de l'Institut Universitari d'Investigació en Criminologia i Ciències Penals de la UV, ISSNe 1989-6352, nº. 2, 2009. p. 93. 
Vejamos, agora, as bases teóricas estabelecidas pelo Supremo Tribunal dos Estados Unidos no tocante ao conceito de material pornográfico. As premissas jurídico-penais expostas pela mais alta Corte norteamericana podem ser assim resumidas:

"Ulteriormente, el Tribunal definió la pornografía en las sentencias dictadas en los casos Roth vs. United Status y Alberts vs. California. Según tales resoluciones, una obra es obscena si aplicando standars comunitarios, aparece en su conjunto como dominada por un interés libidinoso. En ambas resoluciones se aplicó la doctrina sentada en el caso Chaplinsky, afirmando que la pornografía no se hallaba amparada por la libertad de expresión al carecer enteramente de valor social." ${ }^{202}$

Como forma de enriquecer o debate, outrossim, convém reproduzir o raciocínio da Suprema Corte dos Estados Unidos, utilizado para examinar até que ponto estamos diante de efetiva pornografia ou apenas um material irrelevante sob o aspecto penal.

De acordo com o ponto de vista dos Juízes norte-americanos, há que traçar uma relevante distinção entre sexo e obscenidade. Pela intelecção pretoriana, as palavras obsceno, indecente e lascivo significam aquela forma de imoralidade relacionada com a indecência sexual e tendente a excitar ou provocar pensamentos impuros. No entanto, como o Tribunal teve o cuidado de salientar, sexo e obscenidade não são sinônimos, de modo que a presença de sexo não implica, necessariamente, a qualificação de obscenidade. Por consequência, e isto é o que é conhecido como "Teste de Roth", uma obra poderá ser classificada como obscena somente se, tendo em vista a aplicação de padrões contemporâneos em vigor de uma comunidade, o tema dominante do material, tomando a obra na sua totalidade, apela a um interesse lascivo.

\footnotetext{
${ }^{202}$ Seguindo o mesmo passo, é digno de menção outro julgado norte-americano (Tribunal de Warren), no caso conhecido como A book (Fanny Hill) vs. Attorney General, do qual se extrai a seguinte definição de obscenidade, aplicável ao objeto do presente trabalho, cujo conteúdo requer: (1) que o material, tomado em seu conjunto, pareça (ao menos) dominado por um interesse libidinoso; (2) que seja evidentemente ofensivo por causa do desvio dos padrões sociais contemporâneos relativos à representação de materiais sexuais e (3) que se apresente totalmente desprovido de qualquer "valor social". BERENGER, Enrique Ortiz, ob. cit., p. 94. Aqui já se mostra perceptível o pensamento de que se deve ter em conta a "moral social", o conjunto de "valores éticos" aceitos por dada sociedade em determinado período, para a devida aferição do caráter ofensivo ensejador da caracterização de "pornografia".
} 
Nesse ponto, não obstante seja quase que unânime a intelecção doutrinária da imperiosidade de se respeitarem os ditos standarts de comportamento comuns ao seio social $^{203}$, há quem entenda que tal posição - repetida como se fosse praticamente um mantra por seus defensores - representaria um perigo aos preceitos democráticos, haja vista o risco de mal-entendidos ou mesmo a incriminação de condutas irrelevantes.

Como exemplo, calha citar as palavras trazidas por MORALES PRATS e GARCÍA ALBERO, no sentido de que, após reproduzir ambas as vertentes (positiva e negativa) atreladas ao conceito de material pornográfico, é mister fazer uma pontuação mais delimitada dos elementos caracterizadores de obscenidade. Dizem tais autores, mais precisamente acerca dos apontados "padrões":

“Criterio éste de discutible e imprecisa aplicación basado en prejuicios de carácter moral, que no añade un plus adicional al que representan los criterios de valoración de lo que sean contenidos artísticos o literarios, máxime cuando éstos, en última instancia, se apoyan ya, por mucho que se quiera negar, en standards configurados por valoraciones socioculturales. Por tratarse pues de criterios en permanente evolución social, amén de imprecisos, poco más puede señalarse del concepto de 'pornografía'. El precedente método valorativo propuesto supone en cualquier caso el abandono de tradicionales criterios descriptivos, hoy en desuso, para delimitar la pornografía del erotismo, cual la representación de actos genitales explícitos o no, que hay que considerar superados",204

A contrario sensu, se forem vislumbrados outros objetivos em tal proceder (por exemplo, finalidades educativas, artísticas, esportivas e recreativas), afasta-se a ilicitude do ato, tornando-se um irrelevante penal. Essa ideia é defendida por PATRICIA ESQUINAS

\footnotetext{
${ }^{203}$ Padrões esses, frise-se, de caráter subjetivo, pois não existe uma regra objetiva/concreta sobre o real alcance da noção de obscenidade.

${ }^{204}$ MORALES PRATS, F. / GARCÍA ALBERO, R., em: QUINTERO OLIVARES, G. (dir.) / MORALES PRATS, F. (coord.): Comentarios a la Parte Especial del Derecho Penal, Pamplona: Aranzaldi, 2005, p. 334.
} 
VALVERDE, segundo quem o diferencial suficiente à configuração do ilícito penal reside nessa exclusiva natureza sexualmente estimuladora do material. ${ }^{205}$

De sua parte, o Convênio de Budapeste conceitua a pornografia infantil como sendo o material que contenha: a) algum menor em comportamento sexualmente explícito (mera pose ou então a efetivação de atos sexuais como felação, penetração e masturbação); b) uma pessoa que se assemelhe a um menor em conduta sexual explícita; c) imagens realistas que representem uma criança ou adolescente comportando-se de modo libidinoso. Por menor, deve compreender-se toda pessoa até dezoito anos de idade; porém, a Convenção autoriza os estados a definirem essa idade num patamar ainda inferior, tendo como base o mínimo de dezesseis anos.

A Decisão Marco 2004/68/JAI ainda vai mais longe, ao abarcar no conceito de material pornográfico infantil toda e qualquer representação visual de: a) uma criança real, praticando ou participando de alguma maneira de comportamentos sexuais explícitos, alcançando até os casos de exibição lasciva dos genitais ou outras partes do corpo; b) uma pessoa real (em idade adulta) que pareça ser um jovem tomando partido nas condutas acima destacadas; c) por fim, imagens realistas de uma criança inexistente praticando ou participando daquelas condutas.

A definição de material pornográfico infantil apresentada pelo Convênio de Lanzarote (2007) acaba sendo um resumo das noções já apresentadas até agora, qual seja: entende-se como pornografia infantil "todo material que represente de forma visual uma criança ou adolescente mantendo uma conduta sexualmente explícita, real ou simulada, ou toda a representação genital com finalidade precípua de promover excitação sexual do espectador".

Diante desse quadro, fica fácil perceber que, para ostentar status de pornografia infantil, há a exigência concreta de que o material tenha elementos de ordem visual, isto é, que

\footnotetext{
205 "Então, se nem seu conteúdo carece de todo valor literário, artístico e científico que o justifique; se nele são descritos ou mostrados atos sexuais de um modo chamativamente escandaloso ou impudico; e se desde o ponto de vista majoritário na sociedade o material em seu conjunto dirige-se ao interesse lascivo, poder-se-á dizer que tal documentação apresenta natureza pornográfica" (ESQUINAS VALVERDE, Patricia. El tipo de mera posesión de pornografía infantil en el Código Penal Español - art. 189.2: razones para su destipificación. Revista de Derecho Penal y Criminologia, $2^{a}$ Epoca, ${ }^{\circ}$ 18, 2006, p. 192 - tradução livre do autor).
} 
seja alguma imagem (fotografia ou vídeo) envolvendo a captura de menores em situação sexualmente explícita.

Talvez o ponto mais polêmico com relação à conceituação de material pornográfico infantil esteja relacionado com a inclusão (ou não) de crianças ou adolescentes nus, sem que haja participação ativa em comportamentos sexuais. Neste ponto, tanto a jurisprudência do Supremo Tribunal espanhol quanto a doutrina se dividem sobre o efetivo alcance dessas formas de representação visual limitadas à mera nudez.

Sob o aspecto jurisprudencial, a Corte espanhola deparou-se por diversas vezes com situações bastante fronteiriças sobre a questão da mera nudez infantil, sendo lícito afirmar que o Tribunal segue uma linha mais restritiva, buscando definir os limites e contornos do que deveria ser tido como pornografia infantil. Várias decisões judiciais da mais alta Corte espanhola deixaram assentada a ideia pela qual não é toda e qualquer representação visual de menores desnudos sinônimo de material pornográfico ilícito, consoante se verificará no resumido apanhado jurisprudencial bastante atualizado (contemporâneo) acerca do tema adiante apontado.

À guisa de exemplo, a STS no 376/2006 206 , de 8 de março, o mesmo Tribunal pontuou que a imagem de alguém nu não pode ser considerada objetivamente material pornográfico, porque, de fato, mesmo que a pornografia não seja um conceito definido no Código Penal, o certo é que deve comportar a adição de um caráter lascivo ou impudico. ${ }^{207}$

Também em outro esclarecedor caso de fotografias de menores desnudos, o mesmo Tribunal exigiu a presença de outros elementos informativos - naquela hipótese, inexistentes para se operar a adequada contextualização das imagens a fim de se definir a responsabilidade do agente. Na situação concreta, foram verificadas meras suspeitas ou indícios de uso ilícito

\footnotetext{
${ }^{206}$ STS refere-se à sentença do Tribunal Superior espanhol.

${ }^{207}$ CORTINA, José Miguel, ob. cit., p. 36. Na mesma direção apontam as conclusões encetadas pelo mesmo Supremo Tribunal Espanhol, na STS n. ${ }^{\circ}$ 1.342/2003, de 20 de outubro, segundo a qual "la imagen de un desnudo - sea menor o adulto, varón y mujer - no puede ser considerada objetivamente material pornográfico, con independencia del uso que de las fotografías pueda posteriormente hacerse y que no consta cuál fuese en la ocasión de autos". Idem, ibidem.
} 
das fotos, porém tal contexto foi insuficiente à decretação de uma sentença condenatória; afinal, muito embora houvesse comportamento "suspeito", "ello no convierte en pornográfico un material que no solo descontextualizado, sino en el mismo contexto en que fue ofrecido carece de entidad para atacar la indemnidad, seguridad y dignidad de la infancia". ${ }^{208}$

Ora, em face desse posicionamento, não sobram mais dúvidas de que o conceito de pornografia infantil precisa estar bem delineado para evitar a indevida inclusão de condutas ou comportamentos - inexistente qualquer ofensa concreta à dignidade da criança - no espectro de incidência da estigmatizante lei penal sobre o assunto.

A questão, nesse ponto, que mais se coaduna com os ditames garantistas exigidos pelo Estado Constitucional de Direito é buscar aferir, em cada caso, o real contexto libidinoso por detrás das imagens contendo menores nus. Para tanto, torna-se fundamental precisar a forma do material (i. é., como as crianças ou adolescentes aparecem nas fotos), bem como, a destinação de ditas imagens ${ }^{209}$, sempre tendo presente a efetiva ofensa (concreta ou potencial) ao desenvolvimento saudável do menor. ${ }^{210}$

Conforme o entendimento particular de JOSÉ MIGUEL CORTINA, a pedra de toque para chegar à conclusão mais sensata a respeito do tema é a tentativa de fazer a diferenciação, in abstrato, entre as fotografias consideradas "posado erótico" (fotos de crianças, com

\footnotetext{
${ }^{208}$ CORTINA, ob. cit., p. 37.

${ }^{209}$ De acordo com o entendimento abraçado pelo Supremo Tribunal Espanhol, as fotos de menores desnudos somente terão relevância penal - a ponto de configurar o delito de posse de material pornográfico infantil - se estiver presente o escopo de despertar o interesse libidinoso ou a excitação daquele a quem são dirigidas. Em outras palavras, trata-se de condição sine qua non de configuração do ilícito só se a finalidade for saciar a concupiscência libidinosa àquele a que se destina o material. Afinal, lançando-se mão de termos explanados em decisão de um caso concreto pelo STS Espanhol, tirar fotos de crianças nuas, por si só, não integra a ideia de pornografia infantil "con independência del uso que de las fotografías pueda posteriormente; esto es, que si no se prueba el propósito de uso de las fotos y la materialización de la exhibición, no hay elaboración de material pornográfico" CORTINA, José Miguel..., ob. cit., p. 39.

${ }^{210}$ Por isso que, ao lado da jurisprudência, um importante setor doutrinário sustenta o descarte das fotografias contendo nudez infantil da noção de material pornográfico infantil. De acordo com a opinião de JAVIER GUSTAVO FERNANDEZ TERUELO, “con cierta frecuencia los materiales que se intercambian en la red son fotografías de menores desnudos que sin embargo no realizan actos o gestos obscenos con connotación sexual. El precepto se refiere a material pornográfico y en principio, lo pornográfico implica (...) la realización de actos de carácter sexual. En coherencia con lo expuesto habrá que concluir con que en tales supuestos no cabe sanción penal, al faltar un elemento del tipo, en concreto, la calidad de pornográfico.” FERNANDEZ TERUELO, Javier Gustavo. La sanción penal de la distribución de pornografía infantil a través de internet: cuestiones claves. Universidad Nacional de Educación a Distancia, Boletin de la Facultad de Derecho, n. ${ }^{\circ}$ 20, 2002, p. 262.
} 
diferentes graus de nudez, porém com o foco no conteúdo sexual de provocação, instigação, excitação), aquelas tidas como "posados explicitamente eróticos" (ênfase nos genitais do menor) e as fotos da categoria "iniciación" (fotos desprovidas de conteúdo libidinoso, às vezes retiradas de revistas e catálogos), repousando estas últimas fora do contexto ilícito. ${ }^{211}$

Com relação ao tipo de fotografia entendida como erótica (fotos tiradas de modo subreptício, sem o conhecimento do menor), fica difícil estabelecer critérios abstratos fixos para enquadrar essa modalidade no amplo conceito de pornografia infantil, devendo, nessas hipóteses, ser levado em conta os aspectos circunstanciais.

Fazendo-se um apanhado das opiniões e posições jurisprudenciais e doutrinárias que uma mesma representação visual pode - ou não - ser considerada pornografia infantil, dependendo do uso que se faça dela. A fotografia dos genitais de uma adolescente, v.g., clicada e utilizada para fins informativos (ou educacionais) em uma aula de Biologia, ou então para finalidade profissional (caráter forense, investigação) estará longe de ser definida como pornografia infantil, desde que cingida a essas hipóteses. Se, por acaso, tal fotografia for encontrada em algum site com conteúdo pornográfico infantil variado, juntamente com outros tipos de documentos (vídeos ou outras fotos em situação de sexo explícito, por exemplo), estar-se-á diante de nítido material pornográfico infantil.

Restando superada a problemática trazida com a existência de fotografias de menores desnudos (aspecto visual), o material pornográfico infantil poderá apresentar-se em qualquer tipo de suporte. Por isso, deve-se adicionar outra modalidade de material considerado pornográfico na qual não usam elementos de cunho visual, qual seja, o áudio. A gravação de vozes de menores em situações sexualmente explícitas também deverá enquadrar-se na categoria pornografia infantil, pelo menos segundo a lei espanhola.

Essa é a chamada pseudopornografia infantil ${ }^{212}$, nos casos em que apenas a voz (elementos sonoros) do menor é utilizado no contexto libidinoso, objetivando o estímulo da

\footnotetext{
${ }^{211}$ CORTINA, José Miguel, ob. cit., p. 40.

212 A noção exata de pseudpornografia infantil será retomada em tópico específico mais adiante. No entanto, optou-se por uma breve menção por estar abarcada no assunto relativo ao conceito de pornografia infantil.
} 
libido do destinatário da produção pornográfica. Esse tipo de comportamento vem previsto, por exemplo, no artigo 189.7 do Código Penal Espanhol, o qual se refere a todo material em que se tiver sido utilizada a voz da criança ou adolescente.

Além desse ponto, a eventual criminalização de materiais escritos envolvendo sexo explícito com referência a menores (v.g., novelas, romances, textos e artigos) também é relevante. Como tal conduta não vem disciplinada pela legislação espanhola, CORTINA sugere, de lege ferenda, a incriminação de todo relato pornográfico infantil, tomando-se como base o crime (já existente) de corrupção de menores. ${ }^{213}$

Ao final, para evitar as intermináveis discussões e polêmicas, o autor defende a criação de um conceito legal de pornografia infantil, o que facilitaria a aplicação do direito aos casos concretos pelos atores processuais.

A propósito, trazendo a questão à realidade brasileira, é digna de nota a tentativa do legislador em estabelecer a definição de material pornográfico infantil, conforme descreve o artigo 241-E do ECA, verbis: "Para efeito dos crimes previstos nesta Lei, a expressão 'cena de sexo explícito ou pornográfica' compreende qualquer situação que envolva criança ou adolescente em atividades sexuais explícitas, reais ou simuladas, ou exibição dos órgãos genitais de uma criança ou adolescente para fins primordialmente sexuais”.

Muito embora a extensão do conceito de pornografia infantil às hipóteses de mera simulação de ato libidinoso, a nosso sentir, não se justifica (conforme analisado mais adiante), o restante do texto legal conseguiu resumir os elementos até aqui trabalhados.

Assim, é possível adotar a definição legal do ECA, ressalvada a necessidade de ser extirpada dessa definição a ideia de material pornográfico que não tenha efetiva participação de crianças e adolescentes reais.

\footnotetext{
${ }^{213}$ Ob. cit., p. 45 .
} 


\subsubsection{A questão da idade da vítima}

O conceito de menor é um pressuposto lógico para as figuras delituosas objeto de nossa na análise, uma vez que, conforme já adiantado, esse grupo de crimes tem como função primordial a proteção de variados aspectos relacionados com a "sexualidade dos menores de idade".

As normativas internacionais fixam os dezoito anos como idade-limite para considerar a pornografia como sendo "infanto-juvenil". De outro lado, o Convênio Europeu sobre Delitos Informáticos (Convênio de Budapeste, de 2001) também autoriza que os Estados possam estabelecer tal limite em até os dezesseis anos.

No entanto, vale lembrar que a fixação do limite etário para a definição de material pornográfico infantil não é uniforme em todos os Estados signatários do mencionado documento internacional, havendo uma certa discricionariedade de acordo com os critérios culturais mais liberais (ou conservadores) presentes em cada país. ${ }^{214}$

A existência dessas distinções legais sobre a caracterização de pornografia infantil pode ensejar alguns problemas no tocante à persecução penal, já que, em alguns lugares, estará configurado o injusto penal, enquanto, em outros, a conduta será atípica.

Além dessa problemática de cunho pragmático, há também uma questão importante a enfrentar: a comparação entre o limite etário para a definição de pornografia infantil e a idade

\footnotetext{
214 MORILLAS FERNÁNDEZ apresenta lista comparativa entre o critério etário para se reconhecer a autodeterminação sexual de jovens (abaixo do qual se estará diante da figura do vulnerável) e a idade-limite para fins de configuração de pornografia infantil, respectivamente, nos seguintes países: Alemanha (14/14); Austrália (16-18/16); Áustria (14/14); Bélgica (16/16); Dinamarca (15/15); Finlândia (16/15); França (15/15); Grécia (15/18); Islândia (14-16/18); Irlanda (17/17); Itália (16/18); Luxemburgo (16/18); Holanda (16/18); Portugal (/18); Espanha (13/18); Suécia (15/18); Reino Unido (16/16); Estados Unidos (15/18). (MORILLAS FERNÁNDEZ, David Lorenzo, Análisis dogmático y criminológico de los delitos de pornografia infantil: especial consideración de las modalidades comisivas relacionadas con internet. Madri: Dykinson, 2005, p. 72. Já no Brasil, como se sabe, os critérios etários são de catorze anos para fins de consentimento válido e de dezoito para se afastar a caracterização de material pornográfico infanto-juvenil.
} 
após a qual a lei considera válido o consentimento do adolescente para exercer a sua sexualidade de maneira livre e desimpedida.

Com efeito, a fixação de uma certa idade para ter como legítimo o consentimento do jovem para atividades de cunho sexual pressupõe considerá-lo como maduro e desenvolvido para colocá-las em prática. $\mathrm{Na}$ maioria dos países, o limite para reconhecer a autodeterminação sexual juvenil varia entre os doze (como, por exemplo, no caso português), os treze (na Espanha) e os catorze anos (segundo a legislação brasileira - art. 217-A do CP).

Porém, aqui reside o aspecto contraditório da situação: se o mesmo legislador considera como válido o consentimento para atividades sexuais desde os treze anos (no caso espanhol), pode parecer um contrassenso desconsiderar o consentimento para a participação em um contexto pornográfico até os dezoito anos de idade.

Essa incongruência não poderia passar incólume pela análise da doutrina especializada. Segundo ALEXANDRE RAMALHO DE FARIAS, em trabalho que analisa o modelo espanhol, por exemplo, "o erro do legislador parece flagrante ao dar tratamento diverso em casos de índole sexual como no exemplo de um casal que desde os treze anos pode decidir livremente manter relações sexuais sem incidir em nenhum tipo penal, mas não pode gravá-las e divulgá-las por meios tradicionais ou pela Internet, ainda que queiram. Destaca-se que tem capacidade para o mais, que são as relações sexuais desde os treze anos e parece, todavia, não tem para o menos, a divulgação das imagens. Portanto, parece haver dúvidas sobre se o que se busca realmente tutelar é a liberdade ou intangibilidade sexual ou algum outro bem jurídico."215

Mesmo diante de tais críticas com relação ao contrassenso entre a idade a partir da qual se considera a autodeterminação sexual e o limite legal que proíbe a participação em filmagens ou imagens de cunho pornográfico, os ordenamentos penais vêm entendendo necessária uma maior proteção dos menores de dezoito anos, diante da necessidade de evitar o abuso de outros interesses jurídicos (direito à imagem, por exemplo) no contexto pornográfico ou obsceno.

\footnotetext{
${ }^{215}$ Ob. cit., p. 173.
} 
Nesse quadro, trazendo a questão ao campo da pornografia infanto-juvenil, convém lembrar que, no caso do indivíduo que monta um site contendo material pornográfico infantil ou então que explora os menores em atividade de prostituição, a questão etária aparece com clara importância. Sim, pois mesmo que o sistema penal brasileiro admita a liberdade sexual plena dos maiores de catorze anos, é inegável que os adolescentes nessa idade, até pelo caráter de formação de sua personalidade, merecem uma proteção maior.

Por isso, cada caso deve ser analisado especificamente para checar as circunstâncias fáticas, verificar o grau de reprovabilidade das condutas acima apontadas e, assim, fazer um diagnóstico acerca da necessidade de incidência da lei penal, desconsiderando a liberdade advinda da questão etária.

É fundamental diferenciar as situações do casal de adolescentes que pratica relações sexuais de forma consentida, e depois posta as imagens em alguma rede social e o comportamento daquele que explora economicamente os menores (seja por meio da constituição de uma página na Internet ou então pela própria prostituição deles).

O ideal, nessa esfera, é fazer uma integração entre os critérios etários já expostos no item anterior (até doze anos, vulnerabilidade absoluta, entre doze e catorze, relativa e acima de catorze, liberdade plena) com a ausência de indícios de exploração ou abuso da situação de hipossuficiência desses menores. Assim, quando se verificarem estes elementos, mesmo que o adolescente esteja quase atingindo a maioridade plena, a conduta de quem lucra dessa situação deve ser tachada de criminosa, afinal uma coisa é alguém expor, voluntariamente, sua intimidade; outra bem distinta é alguém montar um site e extrair vantagem econômica. 


\subsection{Pornografia infantil e direito comparado}

\subsubsection{Antecedentes legislativos e evolução no tratamento penal da pornografia infantil}

O tema da disciplina penal da pornografia infantil não era foco de grande preocupação por parte dos organismos internacionais até meados da década de 1970, quando o Congresso da União Europeia (EEUU) aprovou a "Lei de Proteção de Menores Contra a Exploração Sexual", em 1977, ano em que se tipifica a distribuição de pornografia infantil sempre que for considerada obscena. Em 1984, houve adendo que retirou o caráter "obsceno", ficando proibida a distribuição de qualquer tipo de pornografia infantil, podendo-se afirmar que, com isso, se conseguiu controlar tal material antes mesmo da Internet. ${ }^{216}$

A fim de estabelecer a forma como o tema vem sendo tratado, é necessário observar os diversos instrumentos internacionais que tiveram como objeto a proteção da criança e do adolescente nos mais diferentes níveis (familiar, social e sexual).

Sem dúvida, o instrumento internacional de maior relevância referente à matéria em análise consiste no Protocolo Facultativo da Convenção dos Direitos da Criança relativo ao tráfico de menores, a prostituição infantil e a utilização de crianças em material pornográfico, realizado em Nova York, em 25 de maio de 2000.

Nesse documento, após a definição do que seria considerado pornografia infantil, são traçados objetivos comuns dos Estados-parte de combater, mediante sanção adequada, tais comportamentos, inclusive, se necessário, com o confisco e a apreensão de bens e materiais, propugnando "ao mesmo tempo a proteção, em todas as fases do processo, dos direitos e interesses das crianças vítimas das práticas proibidas no protocolo."217

\footnotetext{
${ }^{216}$ CORTINA, José Miguel. Ob. cit., p. 11.

${ }^{217}$ CORTINA, José Miguel, ob. cit., p. 21 (cf. tradução livre).
} 
No âmbito da União Europeia, a Carta Europeia dos Direitos da Criança, de 1992, já estabelecia que se adotarão todas as medidas adequadas para impedir que nenhuma criança seja sequestrada, "vendida" ou "explorada" com a finalidade de prostituição e utilização em produções de cunho pornográfico. Ademais, também se busca a proteção da imagem do menor, proibindo-se seu uso de forma lesiva à sua dignidade/intangibilidade.

A Resolução do Parlamento Europeu, de 1997, também estabelece, de modo expresso, a condenação a toda e qualquer prática de pornografia infantil, incluindo aí a vedação à posse de material pornográfico em que se utilizam crianças concretas ou mesmo aqueles que assistem ou são submetidos a tais espetáculos.

Em matéria de pornografia infantil, cabe ressaltar os termos da já apontada DecisãoMarco 2004/68/JAI do Conselho da Europa, cujo conteúdo é evidentemente apoiador da luta contra a exploração sexual de menores. São vários pontos, merecendo destaque os seguintes:

i) os Estados-membros adotarão medidas necessárias para garantir a punição das infrações mencionadas;

ii) As sanções deverão ser efetivas, proporcionais e dissuasórias;

iii) será incorporada uma lista de circunstâncias agravantes: que a vítima seja uma criança ainda não em idade de consentimento sexual, que o autor ponha em perigo de modo doloso ou temerário a vida e o bem-estar físico e mental das crianças; quando ocorre violência real contra o ofendido ou então nas hipóteses em que o autor faça parte de organizações criminosas;

iv) cada Estado poderá introduzir disposições destinadas a inabilitar as pessoas condenadas por essas práticas ao exercício de dadas atividades;

v) introdução da responsabilidade civil e penal das pessoas jurídicas, complementar à das pessoas físicas envolvidas. Inclusão de previsões de multa ou suspensão/proibição (temporária ou permanente) do desempenho de atividades comerciais, chegando até à liquidação ou exclusão da empresa no tocante a eventuais vantagens públicas.

vi) previsão de critérios unificados de jurisdição, sempre tendo em mente a facilidade na atuação dos órgãos oficiais de persecução penal; 
vii) Os Governos deverão prestar a adequada assistência social às vítimas e seus familiares.

Mais recentemente, há que se destacar a Diretiva do Conselho Europeu (COM - 2010 - 94). Do ponto de vista do Direito Penal substantivo, há várias modificações importantes, como o alargamento do conceito de material pornográfico (sendo qualquer tipo, inclusive meras imagens construídas virtualmente), a tipificação de novas formas de abusos on line, como as exibições ou o acesso por meio de chats, aumentando o espectro até para condutas em que não havia posse ou fotos baixadas, incorporando-se o novo delito de grooming (aliciamento dos menores). Sob o aspecto processual, há mudanças tendentes a incrementar a persecução inclusive fora do continente europeu.

De seu lado, várias Recomendações do Comitê de Ministros da Europa preveem há tempos medidas voltadas à proteção da criança de modo integral, com foco especial para o problema da exploração decorrente da produção e difusão de material pornográfico infantil. ${ }^{218}$

No âmbito do Conselho propriamente dito, o instrumento de mais relevância está consubstanciado no "Convênio sobre Cybercrime" (também conhecido como Convênio de Budapeste), realizado em 8 de novembro de 2001 naquela cidade. Como tópico importante ao objeto de discussão neste trabalho pode-se ressaltar a promoção de tipificação, entre outras condutas, da posse de pornografia infantil em algum sistema informático ou qualquer outro meio que possibilite o armazenamento de dados telemáticos.

Outro ponto mais recente que também merece menção especial diz respeito à Convenção do Conselho Europeu para a proteção de crianças contra abuso sexual, de 25 de outubro de 2007, também denominada "Convênio de Lazarote". Segundo CORTINA, este é considerado o primeiro e mais completo tratado internacional específico para a tutela de meninos e meninas menores em vigor no continente europeu. A Espanha, por exemplo,

\footnotetext{
218 Como exemplos, pode-se destacar as Recomendações 9 (1987) e 91 (2011), do Comitê de Ministros responsável pela área de proteção de crianças exploradas sexualmente, sempre com o intuito de reprimir o abuso dos jovens no que toca com a pornografia e o tráfico dessas pessoas.
} 
ratificou há pouco tempo tal instrumento, comprometendo-se a seguir as diretrizes emanadas de tal instrumento legislativo internacional.

Todos os aspectos relacionados com a cadeia de tráfico e difusão de pornografia infantil têm sido objeto de importantes encontros internacionais de especialistas, cujas conclusões vêm trilhando o caminho da luta contra a exploração infanto-juvenil.

Apenas a título exemplificativo, pode-se mencionar o I Congresso Mundial contra a exploração infantil, celebrado em Estocolmo, em agosto de 1996, com representantes de 122 países. A premissa básica resultante desse encontro pode ser resumida na necessidade de proteger o menor de qualquer forma de exploração e violência sexual.

Outrossim, o Congresso de Lyon, de maio de 1998, também trouxe recomendações aos países participantes, principalmente no concernente às medidas governamentais para reprimir esse tipo de crime sexual praticado em detrimento das pessoas em desenvolvimento. É a primeira vez que aparece de maneira expressa a orientação de incriminar todos os comportamentos na cadeia completa do caminho desse tipo de material, incluindo-se aí a tipificação da mera posse de material infantil, inclusive da chamada pseudopornografia, através da Internet. ${ }^{219}$

Já a Conferência Internacional da Luta contra a Pornografia Infantil em Internet, celebrada em Viena em 1999, teve como conclusão uma política de "tolerância zero" e penalização em todo o universo da produção, distribuição, exportação, transmissão, importação, posse intencional e propaganda dessa modalidade de pornografia, sublinhando-se a importância da cooperação dos Governos no setor da internet.

Ainda mais recentemente e fazendo-se uma aproximação ao objeto de nosso estudo, merece destaque o III Congresso Mundial sobre Exploração Sexual de Crianças e Adolescentes que tomou lugar na cidade do Rio de Janeiro, em novembro de 2008. Esse

\footnotetext{
${ }^{219}$ Também houve preocupação em promover o "incremento da cooperação policial e judicial, tanto em questões relativas à aplicação da lei penal como com relação à assistência técnica" (CORTINA, José Miguel, ob. cit., p. 30 , tradução livre).
} 
Congresso deu origem à Declaração do Rio e ao Plano de Ação para prevenir e deter a exploração sexual de infantes e adolescentes, quando se reuniram representantes de cerca de cento e trinta e sete países e membros da sociedade civil. A Declaração roga a criminalização de imagens virtuais de pornografia infantil, definindo-se tal categoria de modo bem amplo. ${ }^{220}$

Estabelecidas essas premissas, convém agora analisar a disciplina específica do tratamento dado por alguns países de destaque no contexto internacional e que, de alguma forma, contribuíram para a modificação da legislação brasileira nessa matéria. ${ }^{221}$

\footnotetext{
${ }^{220}$ Aqui já aparece, com clareza, uma definição bastante abrangente sobre esse tipo de material: "Pornografia infantil virtual inclui representações visuais de abuso de crianças que podem ser encontradas em certos tipos de quadrinhos, animações, jogos de vídeo e desenhos animados, que não envolva uma criança real em sua produção. Isso também pode incluir imagens modificadas digitalmente, em que as imagens de uma criança real são sobrepostas à de um adulto para retratar o abuso sexual infantil". Como resultado de tal Congresso realizado no Rio de Janeiro, também são dignas de nota as orientações de responsabilização penal de provedores de serviços de Internet, as companhias de telefonia móvel, cyber cafés e outros atores que possam estar, ainda que indiretamente, envolvidos na difusão de pornografia infantil. CORTINA, Jose Miguel, ob. cit., p. 31.

${ }^{221}$ São diversos os países de inafastável tradição democrática que, na esteira das diretrizes internacionais, também castigam condutas atinentes à pornografia infantil, o que demonstra a enorme preocupação de se alijar ou ao menos dificultar - a circulação dessa espécie de material na rede mundial de computadores. Mesmo sem adentrarmos em um exame aprofundado, é interessante apresentarmos um breve resumo da disciplina jurídicopenal nesses países. Nesse passo, por exemplo, algumas nações asiáticas adotaram recentemente leis referentes ao combate da pornografia infantil. Em 1995, Taiwan aprovou uma lei que criminalizava a produção de quadros, vídeos, fotos, CDs, "sinais eletrônicos" e outros produtos/conteúdos que contenham condutas indecentes ou interação sexual envolvendo pessoas com menos de dezoito anos de idade. A lei de proteção infantil aprovada nas Filipinas em 1993 (Lei n.o 7610) inclui uma previsão que proíbe o emprego ou coerção de que crianças menores de dezoito anos participem de exibições obscenas, shows indecentes, seja ao vivo ou por meio de vídeo, ou como modelos em publicações obscenas ou material pornográfico. Também impôs sanções à venda ou distribuição de tais materiais. A legislação canadense relativa à pornografia infantil é bem abrangente. A Seção 163 do Código Penal prevê como crime importar, produzir, imprimir ou publicar qualquer material contendo pornografia infantil, inclusive a representação (simulação) de menores em ato sexual. Ademais, a mera posse de material pornográfico infantil também é proibida no Canadá. Na Inglaterra e no País de Gales, a lei define como delito apropriar-se, distribuir, exibir e possuir fotografias "indecentes" de crianças. A lei considera crianças os menores de dezesseis anos. A definição de "indecência" fica a critério da jurisprudência. Ainda a título informativo, há uma vasta lista de outros países que criminalizam a simples posse de material pornográfico infantil: África do Sul, Andorra, Barbados, Bélgica, Bósnia, Bulgária, Croácia, Chipre, Dinamarca, El Salvador, Estônia, Eslováquia, Finlândia, França, Grécia, Holanda, Honduras, Hong Kong, Hungria, Islândia, Irlanda, Israel, Itália, Liechtenstein, Luxemburgo, Lituânia, Malta, Marrocos, Nova Zelândia, Panamá, Nova Guiné, Noruega, Paraguai, Peru, Polônia, Romênia, Sri Lanka, Suécia, Suíça e Turquia (Cf. CORTINA, José Miguel, ob. cit., p. 94.
} 


\subsubsection{Espanha}

O ordenamento jurídico espanhol, assim como a grande maioria dos países da Europa continental, não poderia ficar indiferente à problemática dos delitos relacionados com material pornográfico infantil. O conjunto de normativas internacionais, a partir dos anos 1990 - época que coincide com o surgimento da rede mundial de computadores, o que representou uma mudança de paradigmas diante da patente facilidade do trânsito de dados por meio digital -, representa uma importante fonte de influência ao legislador dos Estados parte, e diante da relevância da Espanha no cenário jurídico europeu, todas as Diretrizes e Decisões-Marco do Conselho da Europa acima apontadas são invocadas para a lastrear as mudanças da lei penal nessa seara.

$\mathrm{Na}$ Espanha, em relação às demais nações do mesmo entorno cultural e territorial, a tipificação dessa classe de figuras delitivas foi mais tardia, uma das últimas. Sem embargo, diante do volume de material doutrinário e jurisprudencial desse país sobre o assunto, mostrase necessário uma incursão mais profunda na evolução legislativa espanhola.

Com efeito, pela redação original do Código Penal de 1995, nem o tráfico nem a posse de material pornográfico infantil eram crimes, senão somente a utilização direta de menores era objeto de punição penal. ${ }^{222}$ Percebia-se, aí, um vácuo legislativo que levava a situações de

\footnotetext{
${ }^{222}$ Segundo a redação original do CP espanhol, no seu artigo 186, "el que, por cualquer medio directo, difundiere, vediere o exhibiere material pornográfico entre menores de edad o incapaces será castigado con la pena de multa de tres a diez meses”. JAVIER GUSTAVO FERNANDEZ TERUELO, em obra dedicada à sanção penal da distribuição de pornografia infantil através da internet, comenta que o primeiro caso de pornografia infantil levado a julgamento na Espanha (Julgado 24, de Barcelona), que redundou na inevitável absolvição do acusado em razão da ausência de previsão típica que abarcasse as hipóteses de venda, exibição e distribuição desse tipo de material, foi o sinal para a necessária mudança legislativa. Naquele caso, dois estudantes de tecnologia da comunicação foram flagrados com cerca de duas mil imagens de conteúdo sexual envolvendo crianças entre três e quinze anos no disco rígido de seu computador. No entanto, a Corte viu-se obrigada a absolvê-los, uma vez que o artigo 186 do CP efetivamente exigia a necessidade de uma elação direta entre o autor e o sujeito passivo, isto é, a presença efetiva do menor ou incapaz, o que não se observava na hipótese submetida a julgamento, visto que a relação entre quem difunde as imagens e os menores utilizados, por óbvio, é indireta. De outro lado, tampouco pôde ser enquadrada a conduta na figura do artigo 189.1 do mesmo Codex (utilização de menores com finalidade ou em espetáculos exibicionistas), já que quem difunde as imagens não costuma ser os criadores delas, além de desconheceram, no mais das vezes, a quem pertencia e até mesmo os menores utilizados naquele contexto. (Derecho penal e internet: especial consideración de los delitos que afectan a jóvenes y adolescentes, Valladolid: Lex Nova, 2011, p. 109).
} 
impunidade diante da nova realidade fática, gerando severas críticas por parte da doutrina e da própria jurisprudência, que se via impotente na subsunção do fato à norma.

Justamente por causa dessa carência ou lacuna legislativa para abarcar as hipóteses constatáveis no mundo fenomênico e também em virtude das vozes punitivistas, o legislador espanhol decidiu dar vazão a esses reclamos, com a edição da Lei Orgânica 11/1999, de 30 de abril, um importante marco legislativo acerca do tema naquele país.

É conveniente dizer que o principal objetivo da referida lei foi o de reintroduzir no CP espanhol o delito de corrupção de menores, como forma de garantir uma autêntica proteção da integridade e liberdade sexual de menores e incapazes. Segundo a Exposição de Motivos da lei, as normas constantes da redação original de 1995 não respondiam adequadamente, tanto quanto a tipificação de condutas como a cominação das respectivas sanções penais, às exigências da sociedade internacional.

Em termos gerais, a mencionada reforma legislativa derivou, em parte, das diretrizes constantes da Resolução 1099 (1996), relativa à Exploração Sexual de Crianças, da assembleia Parlamentar do Conselho da Europa, bem como da Resolução do Parlamento Europeu, de 6 de novembro de 1997, referente à Comunicação da Comissão sobre a luta contra o turismo sexual infanto-juvenil.

Em resumo, nos pontos que interessam à nossa análise, a LO de 1999 trouxe significativas modificações à redação do artigo 189.1 do CP, mantendo-se a alínea 'a' original (utilização de menores em espetáculos exibicionistas ou pornográficos), adicionando-se a questão da finalidade dessa utilização, com o fim de participar nesses espetáculos ou a finalidade de servir para a elaboração de material pornográfico.

Ademais, objetivando-se a incriminação dos casos de distribuição de material pornográfico infantil, foi introduzida a alínea 'b', pela qual se castiga aquele que "produzir, vender, distribuir, exibir ou facilitar a exibição, por qualquer meio, de material pornográfico em cuja elaboração tenham sido utilizados menores ou incapazes", e trouxe um importante 
adendo: "ainda que tal material tenha origem no estrangeiro ou seja de procedência desconhecida". ${ }^{223}$ Também foi introduzida no ordenamento espanhol o tipo penal da mera posse de material pornográfico infantil, desde que voltado para uma dessas condutas (também chamada de posse finalística).

Mais adiante, a Lei Orgânica 15/2003, de 25 de novembro, determinou uma extraordinária ampliação do âmbito típico envolvendo, entre outros tópicos, a disciplina penal da pornografia infantil. De acordo com a própria Exposição de Motivos da lei, "a respeito dos delitos relativos à corrupção de menores, foi introduzida uma importante reforma do delito de pornografia infantil, endurecendo as penas, melhorando a técnica na descrição das condutas e introduzindo tipos como a posse para próprio uso de material pornográfico com utilização de menores ou incapazes, bem como os casos da denominada pornografia infantil virtual".

Em linha gerais, três foram as grandes modificações operadas pela citada norma: $i$ ) exasperação da pena cominada ao tipo básico (aumento da pena máxima prevista, que antes era de três, para quatro anos de prisão), assim como, uma sanção penal bastante significativa para os novos tipos agravados (na menos do que quatro a oito anos de prisão para os casos mais graves, como utilização de menores de treze anos, abuso da posição de hierarquia ou do pátrio poder, integração do agente em organização criminosa etc.); ii) a introdução do tipo penal da posse de material pornográfica para autoconsumo, até então conduta atípica e iii) a

\footnotetext{
${ }^{223}$ A lei, nesse aspecto, apresenta duas grandes novidades: a inclusão da expressão "por qualquer meio" - o que possibilita alargar a incriminação a todos os meios tecnológicos, incluindo a internet -, bem como a questão da extraterritorialidade (procedência estrangeira ou desconhecida). O espírito da mudança legislativa foi o de alcançar a proteção de todos os menores utilizados nesse contexto, pouco importando seu país de origem. Importante notar que mais recentemente, a Lei Orgânica 3/2005, de 8 de julho estabeleceu uma exceção absoluta ao princípio da territorialidade para certos delitos, inclusive o ora em exame, sempre que os responsáveis se encontrem na Espanha ou em qualquer outro lugar que, segundo os tratados ou convênios internacionais, deva ser processado em solo espanhol. Importante notar que, no Brasil, não existe essa exceção legal ao princípio da territorialidade, muito embora, vale salientar, a competência para a persecução dos crimes informáticos envolvendo pornografia infantil, quando houver elementos de prova da procedência estrangeira dos arquivos, é da Justiça Federal. Nesse sentido, em artigo dedicado à análise do luar do crime nos delitos virtuais, assevera FÁBIO TOFIC SIMAMTOB: "no tocante à pornografia infantil, (...) o STJ acabou prestigiando entendimento antagônico ao adotado nos crimes contra a honra, ao assentar que, por ser cometido pela rede mundial de computadores, o crime se consuma no exterior, aplicando-se, por consequência, o art. 109, V, da CF, o qual prevê que: 'aos juízes federais compete processar e julgar: (...) V - os crimes previstos em tratado ou convenção internacional, quando, iniciada a execução no País, o resultado tenha ou devesse ter ocorrido no estrangeiro, ou reciprocamente. (STJ, 3. ${ }^{\text {a }}$ Sec., CC 111.338-TO, rel. Og Fernandes, j. 23.06.10)." SIMANTOB, Fábio Tofic. Delitos virtuais: o lugar do crime na visão dos tribunais. Revista do Advogado, AASP, ano XXXII, n. ${ }^{\circ} 115$, p. 61/67, abr. 2012.
} 
criação do tipo penal de tráfico (produção, venda) da chamada pornografia virtual, isto é, quando não haja efetiva utilização de menores nas filmagens, senão o posterior emprego de vozes ou imagens alteradas.

Como não poderia deixar de ser, para setor importante dos pensadores, sobrevieram muitas críticas à nova sistemática, principalmente, acerca da duvidosa legitimidade do crime de posse de material pornográfico infantil para consumo próprio (destacando a dúvida sobre a conformidade à Constituição Federal na hipótese da pornografia real e a segura ilegitimidade na pornografia virtual) ${ }^{224}$. A ideia foi clara: reduzir lacunas de impunidade e acabar com a oferta mediante a aniquilação da procura. ${ }^{225}$

Nesse contexto, houve uma evidente evolução incriminadora no tocante a qualquer ato ou conduta relacionada com a utilização ou a difusão de material (vídeos e fotos, por exemplo) envolvendo menores ou adolescentes. Trata-se de verdadeira escala punitiva que pode ser compreendida em uma constante crescente em que a resposta punitiva estatal partiu de um aspecto mais pessoal (específico, subjetivo), em que ocorre tão-somente a real utilização de uma criança concreta - aspecto concreto - para um mais difuso, quando se pune, por exemplo, a posse de material pornográfico infantil virtual (ou simulado) em que se protege a chamada "moralidade coletiva" - aspecto abstrato. ${ }^{226}$

\footnotetext{
${ }^{224}$ De antemão, FERNANDEZ TERUELO teceu contundentes críticas à mudança normativa, principalmente no tocante à ausência de respeito aos critérios de exclusiva proteção de bens jurídicos, ofensividade e proporcionalidade, das quais o presente trabalho compartilha, como se verá mais adiante: "la valoración de la reforma del año 2003 en su conjunto no puede ser positiva. Una vez más, el Derecho penal decide intervenir en ámbitos en los que no resulta sencillo determinar bien afectado alguno. Castigar la posesión de pornografía infantil para autoconsumo o formas de pseudo pornografía en las que no se han utilizados menores reales, al margen del reproche moral que éstas pueden determinar, parece escasamente compatible con principios como el de ofensividad, proporcionalidad, entre otros. Debe, por cierto, advertirse de que, pese al carácter ampliamente expansivo de la intervención penal, no faltan todavía voces que solicitan, en lo que constituiría una nueva 'vuelta de tuerca', el castigo de la llamada apología de la pederastia (...). Por último, debe resaltarse que las nuevas previsiones se incorporan con una técnica legislativa caótica." Derecho penal e internet..., p. 115.

${ }^{225}$ Para se verificar o espírito do qual o legislador estava imbuído, convém citar o pensamento de MORALES PRATS e GARCÍA ALBERO segundo o qual "los grupos parlamentarios que han impulsado y aprobado la reforma de 2003 en la materia han optado por una opción de política criminal de amplia incriminación, opción a la que no estaban encorsetados ni obligados internacionalmente por el convenio de Budapest." (MORALES PRATS, Fermín; GARCÍA ALBERO, Ramón. 'Comentarios a la parte especial de Derecho penal', Thomson

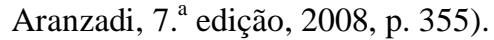

${ }^{226}$ As palavras de GUISADO MORENO são esclarecedoras ao demonstrar a marcha proibitiva na Espanha quanto a essa matéria (pornografia envolvendo infantes), e que pode ser aplicada com perfeição à realidade legislativa brasileira, conforme se demonstrará: "primero se castigó penalmente la creación y elaboración de material pornográfico infantil; posteriormente, con motivo de la reforma operada en 1999 se actuó contra la
} 
Mais recentemente, outras novidades - todas de cunho ainda mais punitivo - foram implementadas pela edição da Lei 5/2010, de 22 de junho, cuja Exposição de Motivos deixou clara a necessidade de se transpor os termos da já mencionada Decisão Marco 2004/68/JAI, com o incremento de penas e a criação de novas figuras e circunstancias agravantes, tudo para se atingir a almejada proteção total das supostas vítimas de pornografia infantil.

Assim, de modo sintético, as mudanças impostas pela referida Lei mais relevantes ao tema analisado são: $i$ ) a alteração do artigo 189.1, alínea 'b’ do CP espanhol para criminalizar a conduta de captação de crianças e adolescentes (também conhecida como grooming) para fins pornográficos, adicionando-se à redação original a expressão "oferecimento" desse tipo de material; ii) a incriminação da obtenção de lucro derivado de qualquer dos demais comportamentos típicos; iii) a elevação das penas dos tipos agravados, que passa a ser de cinco a nove anos de prisão e $i v$ ) a incorporação da responsabilidade penal das pessoas jurídicas (provedores, por exemplo).

A respeito da paradigmática introdução da responsabilização de pessoas jurídicas no sistema espanhol, convém mencionar as considerações de FERNADEZ TERUELO, no sentido de que o legislador, por meio da Reforma 5/2010, incorporou os delitos relativos à prostituição e corrupção de menores e, portanto, os vinculados à pornografia infantil, ao novo modelo de responsabilidade penal das pessoas jurídicas. Como na maioria dos casos próprios desse âmbito, somente de forma muito excepcional esse tipo de condutas poderá ser levado a cabo mediante entidades jurídicas (empresas). ${ }^{227}$

cadena de distribución (todos los intervinientes en esta cadena, incluyéndose la posesión orientada al tráfico); finalmente, con la reforma de 2003, se penaliza asimismo la mera tenencia o posesión de este material aun cuando solo se destine al proprio consumo. Es obvio que con ello el legislador español, en un intento de reducir al número de estos delitos ha decidido actuar también contra el último eslabón de la cadena, eso es, el consumidor, partiendo de la hipótesis de que a menor número de consumidores menos demanda, e a menos demanda menos tráfico. O dicho en términos aun más simples: si no hay clientela no hay mercado". GUISADO MORENO, Ángela. El consumo de pornografía infantil en Internet. El lado oscuro de la red". RCE NUM 81-2007, p. 44. Essa crítica não tem tanta relevância quando se fala em pornografía infantil virtual. No entanto, é importante trazer essa posição para checar a evolução histórica do tema.

${ }^{227}$ FERNANDEZ TERUELO, Javier Gustavo. Derecho penal e internet..., p. 150-151 (tradução livre). As penas aplicáveis às pessoas jurídicas em função de alta gravidade são, entre outras: (i) dissolução da pessoa jurídica, mediante a perda definitiva da personalidade jurídica, assim como impede que a pessoa jurídica se envolva em qualquer outra atividade ligada ao tráfico jurídico, ainda que seja atividade considerada lícita; (ii) 
Conforme se percebe, a legislação espanhola trilhou o caminho da maximização do Direito Penal para abarcar toda e qualquer conduta relativa à pornografia infantil, mesmo que à custa do sacrifício dos princípios basilares aplicáveis ao tema. Por esse motivo, a postura eminentemente intervencionista, muito embora ancorada nas diretrizes internacionais, a nosso ver, foi demasiada alargada, merecendo as inúmeras críticas por parte da doutrina especializada. $^{228}$

\subsubsection{Itália}

A maneira pela qual a legislação italiana vem tratando o tema da disciplina penal da pornografia infantil contém muitas semelhanças com o sistema espanhol, bem como, dos países europeus em geral.

Nesse sentido, e primeira alteração legislativa de relevo do Código Penal italiano, no âmbito da pornografia infantil, foi operada pela promulgação da chamada "Lei da Pedofilia" (Lei n. ${ }^{\circ} 269$, de 03.08.1998), a qual modificou a redação dos artigos 600-ter ${ }^{229}$ do CP italiano,

fechamento do estabelecimento por prazo de até cinco anos; e (iii) proibição de realizar no futuro as atividades cujo exercício serviram de modo a encobrir o delito cometido. Como se vê, trata-se de um passo além na disciplina da pornografia infantil, objetivando-se alargar ao máximo o espectro de tutela penal. Além das penas citadas, a prática de tais atos delituosos pode levar à imposição de sanções específicas, como a "liberdade vigiada", medida de segurança que se embasa na ideia da existência de um prognóstico negativo de reinserção social, e que se executa após findo o cumprimento da pena privativa de liberdade (previsão inexistente na legislação brasileira). Pode ter duração, conforme o caso, e de acordo com a gravidade do delito cometido, de um a dez anos. Outra possibilidade de aplicação de sanções específicas vem prevista no artigo 192, e trata da "inabilitação especial": tal penalidade se reflete no impedimento ao exercício dos direitos de tutela, curatela, guarda, emprego ou cargo público ou exercício de profissão ou ofício, por um prazo de seis meses a seis anos, assim como na privação do pátrio poder.

${ }^{228}$ Segundo FERNANDEZ TERUELO, "la gran expansión penal en el castigo a toda conducta relacionada con la pornografía infantil parece deteterminar el castigo, en algún caso, del mero hecho de obtener satisfacción sexual con la contemplación de imágenes de menores, lo que, en definitiva, queda dentro de la moral sexual de cada uno. En esta línea, ya desde la reforma de 1999, varias de las conductas descritas en los tipos se castigan por tratarse de prácticas que se apartan de las sexualmente mayoritarias." (ob. cit., p. 119).

${ }^{229}$ Segundo a redação introduzida pela Lei de 1998, "600-ter. Pornografia infanfil. Qualquer forma de exploração em virtude da qual se utilize menores de dezoito anos com o objetivo de realizar exibições pornográficas ou produzir material pornográfico será castigada com pena de prisão de seis a doze anos $e$ multa (...). Com a mesma pena se castigará o sujeito que comercialize o material pornográfico referido no parágrafo anterior". 
estabelecendo as condutas relacionadas com tráfico de pornografia infantil, bem como do artigo 600 -quater ${ }^{230}$, que dispõe acerca da mera procura/posse de dito material.

No caso da incriminação de comportamentos voltados à produção, distribuição e divulgação de pornografia infantil, o tipo penal em questão (artigo 600-ter) não apresenta maiores dificuldades de compreensão de seu alcance, abarcando as diferentes condutas voltadas à difusão desse material, principalmente na rede mundial de computadores.

De seu turno, o dispositivo legal que disciplina as condutas relativas à aquisição e posse de pornografia infantil (artigo 600-quater) diferencia-se da maioria dos outros ordenamentos europeus - com exceção do exemplo alemão, como se verificará no tópico seguinte - à medida que penaliza a "busca" ou "procura" desse peculiar tipo de material pornográfico, além do fato de o agente "dispor" desses documentos. Ou seja, há uma antecipação da tutela penal para abranger atos anteriores à própria aquisição das imagens ou arquivos.

Segundo a análise de MORILLAS FERNÁNDEZ, com o emprego do vocábulo procurar, o legislador italiano buscou abarcar todo aquele material obtido por meio de uma das condutas previstas no artigo 600-ter, ao passo que, ao mencionar o núcleo do tipo "dispor", pretendeu alcançar as novas formas de difusão tecnológica do material, incluindo o âmbito virtual, pela via telemática. $^{231}$

A novidade trazida pela mudança legislativa repousa na circunstância de permitir castigar penalmente o possuidor de material pornográfico fabricado ou criado para uso

\footnotetext{
${ }^{230}$ Esse é um dos pontos mais delicados e que gerou, assim como no ordenamento espanhol, um imenso debate acerca da legitimidade da tipificação da mera detenção de material pornográfico infantil. Esta é a redação legal: “600-quater. Posse de material pornográfico. Aquele que, a expensas do previsto no artigo 600-ter, intencionalmente procure ou disponha de material pornográfico produzido mediante a exploração sexual de menores de dezoito anos será castigado com pena de prisão de até três anos ou multa".

${ }^{231}$ MORILLAS FERNÁNDEZ, David L. Morillas. Los delitos de pornografía infantil en el derecho comparado. Em: Cuadernos de política criminal. Segunda época, Madrid: Centro de Estudios Superiores de Especialidades Jurídicas, 2004, p. 46-47. Consoante o mesmo autor, o legislador procurou incriminar dois comportamentos representativos de uma cadência temporal, isto é, enquanto o primeiro se consuma de forma instantânea, com efeitos permanentes, o segundo é delito permanente. Com isso, essas circunstâncias temporais podem fazer incidir uma dupla incriminação, o que afrontaria o princípio do ne bis in idem.
} 
estritamente privado. Esse sistema de incriminação introduzida pela referida lei procura unicamente prevenir a possível futura circulação de material com estas características como atividade empreendedora. ${ }^{232}$

Não bastasse o alargamento trazido pela referida Lei da Pedofilia, os artigos em discussão sofreram nova e significativa modificação. Mais recentemente, entrou em vigor a Lei n. ${ }^{\circ} 38$, de 6 de fevereiro de 2006, que teve como escopo adaptar a legislação italiana aos termos da já mencionada Decisão Marco 2004/68/JAI, criando-se novos tipos penais e promovendo o recrudescimento das sanções previstas, em nome da proteção efetiva de crianças e adolescentes. ${ }^{233}$

As principais modificações que merecem destaque dizem respeito à alteração do preceito secundário da norma do artigo 600-quater do CP italiano, afastando-se a antiga previsão da alternatividade pena privativa de liberdade e multa, determinado-se a cumulação de ambas. Substitui-se, também, a referência à elaboração de material pornográfico produzido mediante a exploração sexual (sfruttamento sessuale) de menores de dezoito anos pela menção apenas à utilização desse grupo de indivíduos.

Ademais, o artigo $4 .^{\circ}$ da nova Lei acrescenta ao mencionado artigo 600 -quater a alínea '1', criando uma nova figura delitiva, consistente na incriminação da conduta de produzir e difundir material pornográfico com imagens fictícias de menores (pornografia virtual). ${ }^{234}$

\footnotetext{
${ }^{232}$ Deve-se encarar essa afirmação com cautela, alertando-se sobre uma possível (e injustificável) repressão penal da simples consulta, via internet, de uma página da web de conteúdo pedófilo, o que seria extreme de qualquer critério de ofensividade.

${ }^{233}$ A redação vigente do mencionado dispositivo legal, com a mudança de 2006, prevê: "Art. 600-quater. (Detenzione di materiale pornografico). Chiunque, al di fuori delle ipotesi previste dall'articolo 600-ter, consapevolmente si procura o detiene materiale pornografico realizzato utilizzando minori degli anni diciotto, $e^{\prime}$ punito con la reclusione fino a tre anni e con la multa non inferiore a euro 1.549. La pena e' aumentata in misura non eccedente $i$ due terzi ove il materiale detenuto sia di ingente quantità".

${ }^{234}$ Assim ficou disciplinada a atual figura da pornografia infantil virtual na Itália: "Art. 600-quater.1. (Pornografia virtuale). Le disposizioni di cui agli articoli 600-ter e 600-quater si applicano anche quando il materiale pornografico rappresenta immagini virtuali realizzate utilizzando immagini di minori degli anni diciotto o parti di esse, ma la pena é diminuita di un terzo. Per immagini virtuali si intendono immagini realizzate con tecniche di elaborazione grafica non associate in tutto o in parte a situazioni reali, la cui qualità di rappresentazione fa apparire come vere situazioni non reali". (cf. informação disponível em http://www.bancaditalia.it/UIF/altre-funzioni/pedopornografia/l-2006-38.pdf). Veja-se que até 2006, a lei italiana não fazia referência à pseudopornografia, de modo que tal reforma legislativa, parece evidente, procurou alinharse com as já mencionadas diretrizes internacionais, mormente aquelas constantes da Decisão-Marco de 2004.
} 
Ao menos aqui, distintamente da legislação brasileira, a Itália demonstrou uma postura menos punitivista, visto que deixou de contemplar no âmbito típico a conduta de possuir material pornográfico virtual (pseudopornografia), como o faz a legislação brasileira, conforme o disposto no artigo 241-C do Estatuto da Criança e do Adolescente - tipo penal que será abordado em detalhes mais adiante.

Em outras palavras, o espectro de incidência da normal penal no tocante à pseudopornografia limitou-se aos casos de produção e difusão (divulgação, distribuição), entendendo que a proteção penal deveria levar em conta o maior desvalor da conduta de quem trafica o material, em detrimento daquele usuário de pornografia nas hipóteses em que não tenha havido a efetiva utilização de menores reais no contexto libidinoso.

Sem embargo dessa diferença de tratamento, segundo alguns doutrinadores, a lei italiana é obscura e gera uma pluralidade de interpretações, o que reflete um certo excesso moralizante por parte do legislador. O texto legal que disciplina a matéria, assim como no caso brasileiro com a inovação trazida pela Lei n. ${ }^{\circ} 11.829 / 08$, possui um caráter "emergencial", de modo que, em nome da proteção aos menores, desconsideraram-se outros valores de estatura constitucional. ${ }^{235}$

O texto legal em análise também é objeto de outras críticas. Em primeiro plano, com relação ao art. 600-ter, partindo da análise dos trabalhos preparativos no âmbito do Poder Legislativo local, constata-se que o legislador procurou dar maior determinação ao dispositivo, porém não foi bem sucedido. Desde logo, a lei não define o que é exibição pornográfica, ou seja, não estabelece o alcance do termo pornografia, embora este seja mais restrito que a antiga definição de obsceno, entendido como algo que fira o sentimento comum de pudor.

Segundo MANNA, tanto no Senado como na Câmara dos Deputados, as duas Casas Legislativas daquele país, procurou-se delimitar a expressão ao vincular-se o material

\footnotetext{
${ }^{235}$ MANNA, Adelmo. Profili problematici della nuova legge in tema di pedofilia. L'Indice Penale, Padova, v. 2 , n. ${ }^{\circ} 1$, jan./abr. 1999, p. 48.
} 
pornográfico com o pré-requisito da exploração dos menores, de modo a restringir a incidência do tipo. ${ }^{236}$

Todavia, tal interpretação não pode ser assegurada, como demonstraram determinados casos veiculados na imprensa. Outras propostas apresentadas também não eram satisfatórias, como definir de fundo sexual a imagem ou texto cujo escopo primário seja a ênfase descritiva ou distorcida das características dos menores. Nesse sentido, verifica-se a incompatibilidade dessas soluções com o princípio constitucional da determinação, decorrente do princípio da legalidade estrita.

Diante disso, considera-se preocupante o parágrafo terceiro do art. 600-ter, onde há o inciso "com qualquer meio, inclusive por via telemática", contendo termo residual demasiadamente indeterminado, deixado para a discricionariedade do caso concreto, o que repercute no âmbito da culpabilidade. Do mesmo modo, deve ser ressaltada a demasiada amplitude do tipo quanto aos provedores de internet, na medida em que estes poderão responder pela conduta a título de dolo eventual, por aceitarem o risco de consentir no acesso à rede". 237

No tocante ao art. 600-quater, que trata da posse de material pornográfico infantil, há maior perplexidade, pois em nome de uma tutela absoluta e incondicionada do menor, viola-se o direito constitucional, por exemplo, à privacidade, havendo uma intervenção do direito penal sem que haja lesão ou perigo concreto de lesão a outros sujeitos.

Em resumo, o crime em questão revela uma excessiva distância entre a conduta e o bem jurídico protegido, de modo a constituir uma espécie de "delito-obstáculo", em que a antecipação da tutela penal não é facilmente justificável ou legitimável.

Por fim, cabe mencionar a previsão de três circunstâncias agravantes - quando a vítima for menor de treze anos, quando o agente tiver grau de parentesco com o ofendido e na

\footnotetext{
${ }^{236}$ Assim, não estaria abrangida a hipótese, v.g., do álbum de família virtual, com fotos dos filhos menores sem roupa.

${ }^{237}$ MANNA, Adelmo, ob. cit., p. 48-50.
} 
hipótese de emprego de violência ou grave ameaça - e também uma atenuante consistente na necessidade de diminuição de pena quando o menor recobrar sua autonomia.

\subsubsection{Portugal}

O Código Penal português, por meio da reforma legislativa operada em 2007, criou a figura criminosa autônoma da posse de material pornográfico infantil, prevista no artigo $176 .^{\circ}$ sob o nomen juris "pornografia de menores" 238.

O primeiro aspecto interessante a ser destacado pela nova redação legal repousa no salutar deslocamento do mencionado tipo penal de pornografia infantil dos antigos artigos 172 e 173 do CP - âmbito dos crimes contra a liberdade e autodeterminação sexual - para artigo próprio. Com efeito, a inserção sistemática daqueles dispositivos não se compadecia com condutas típicas que nada tinham que ver com o bem jurídico aí protegido.

Além da questão topográfica, que conferiu mais lógica ao sistema, é importante verificar que o surgimento dessa nova modalidade criminosa afigura-se, na mesma linha dos ordenamentos já mencionados, como um nítido sintoma da onda de neocriminalização de condutas no âmbito dos crimes sexuais cujas vítimas sejam crianças e adolescentes.

A finalidade da criminalização de condutas relacionadas à indevida utilização de menores em representações (foto e vídeo) de cariz pornográfico revela-se na tentativa de se

\footnotetext{
${ }^{238}$ De acordo com a redação vigente: “Art. 176. - Pornografia de menores 1. Quem: a) Utilizar menor em espetáculo pornográfico ou o aliciar para esse fim; b) Utilizar menor em fotografia, filme ou gravação pornográficos, independentemente do seu suporte, ou o aliciar para esse fim; c) Produzir, distribuir, importar, exportar, divulgar, exibir ou ceder, a qualquer título ou por qualquer meio, os materiais previstos na alínea anterior; d) Adquirir ou detiver materiais previstos na alínea ' $b$ ' com o propósito de os distribuir, importar, exportar, divulgar, exibir ou ceder; é punido com pena de prisão de um a cinco anos. (...) 3. Quem praticar os actos descritos nas alíneas ' $c$ ' $e$ ' $d$ ' do $n .^{\circ} 1$ utilizando material pornográfico com representação realista de menor é punido com pena de prisão até dois anos." Como se percebe, a alínea 'd' do item ' 1 ' prevê a modalidade de posse de material pornográfico "real", enquanto o item ' 3 ' disciplina a chamada "pornografia virtual" ou pseudopornografia.
} 
evitar a difusão dessas imagens em um "circuito pedófilo" cuja enorme vastidão é desconhecida por completo, principalmente diante da sociedade tecnológica atual.

Desse modo, a incriminação da atuação e utilização de crianças e adolescentes em material pornográfico tem como fundamento primordial a ideia pela qual é a autodeterminação sexual dos menores que ainda é posta em xeque mediante essa classe de condutas.

Diante disso, inafastável a observação de que a reforma legislativa de 2007, nesse particular, teve como fonte imediata a Decisão-Quadro 2004/68/JAI, do Conselho, de 22 de dezembro de 2003, relativa à luta contra a exploração sexual de crianças e a pornografia infantil.

O objetivo da incriminação desse tipo de conduta repousa justamente no propósito de barrar, evitar ou dissuadir a proliferação e a divulgação de ofensas à liberdade e à autodeterminação de crianças e adolescentes (bens jurídicos pessoais) envolvidos nesse contexto de abuso ou exploração sexual.

No entanto, nesse caso, pode-se sustentar, também, a existência de um direito supraindividual, coletivo, de modo que a difusão desse tipo de material ofenderia não apenas aqueles menores efetivamente utilizados nas filmagens ou fotos, senão toda a juventude genericamente considerada.

Como se vê, trilhando a tendência mundial de combate à pedofilia, os ordenamentos jurídico-penais apontados não ficaram alheios aos reclamos da comunidade internacional nesse âmbito. ${ }^{239}$ Conforme se verá a seguir, o Brasil também se rendeu a essa pressão, sem maiores discussões a respeito da legitimidade desse tipo de incriminação.

\footnotetext{
${ }^{239}$ A despeito dessa inegável inclinação geral de endurecimento do sistema penal sobre o tema da pornografia infanto-juvenil, há países que não se renderam aos reclamos internacionais e não chegaram ao ponto de incriminar a mera posse desse material, podendo ser citados os seguintes exemplos: Argentina, Uruguai, Japão e Montenegro (isso de acordo com o Relatório do Centro Internacional para Crianças Desaparecidas e Exploradas - ICMEC, na sigla original em inglês -, cf. quadro comparativo constante do relatório "Pornografia Infantil - Legislação Modelo \& Revisão Global”, 6a edição, 2010, ICMEC, p. 13 e seguintes. Disponível em http://www.icmec.org/en_X1/icmec_publications/6th_Edition_Portuguese_Final_pdf, acessado em 18 de dezembro de 2102). Interessante notar que ordenamentos tão próximos, em termos culturais, com o nosso (como
} 


\subsection{A legislação brasileira}

Em primeiro plano, cabe dizer que a legislação brasileira, a exemplo dos ordenamentos de mesma tradição liberal do mundo ocidental, não tem nenhum dispositivo que tipifique a conduta de desejo forte e repetido, nem de fantasias sexuais, com crianças. Os comportamentos puníveis dispostos pelo Código Penal ou pelo Estatuto da Criança e do Adolescente (Lei $n^{\circ}$ 8.069/90) dizem apenas com a exteriorização de tais desejos, como as condutas de abuso sexual (estupro de vulnerável, conforme já destacado), bem assim aquelas relativas a toda a cadeia do tráfico de material pornográfico com crianças e adolescentes. $\mathrm{Ou}$ seja, o Direito Penal não se preocupa em coibir ou punir atos íntimos (cogitação, fantasia), mas apenas atitudes externalizadas (atos executórios ou de consumação).

A Lei $\mathrm{n}^{\circ}$ 8.069/90 tutela os direitos da criança e do adolescente em seus mais diversos aspectos, sendo que importará ao presente trabalho a menção às regras descritas nos artigos 240 e 241 - todos com a alteração legislativa introduzida pela Lei 11.829/08 - com especial relevo aos tipos dos artigos241-B, caput e $241-\mathrm{C}$, c/c artigo $241-$ E. $^{240}$

Quando da promulgação do Estatuto da Criança e do Adolescente, em 1990, momento ainda anterior ao surgimento da rede mundial de computadores, apenas dois tipos penais abarcavam a situação gerada pela pornografia infantil. Segundo a redação original dos artigos 240 e 241, havia a previsão de punição apenas para as condutas de produção ou direção de representação de peça teatral, televisiva ou de película cinematográfica, na qual se utilizasse criança ou adolescente em cena de sexo explícito ou pornográfica (art. 240) e também o fato de fotografar ou publicar cenas da mesma natureza com crianças ou adolescentes (art. 241).

os sul-americanos Uruguai e Argentina) acabaram enveredando outro caminho nesse assunto, tendo, apesar de previsão legal expressa de pornografia infantil como um crime cibernético, deixado o rigor penal destinado apenas aos produtores e difusores de pornografia infantil.

${ }^{240}$ Estes delitos fazem parte do capítulo que define os crimes em espécie praticados contra a criança e o adolescente. 
Em face das dificuldades de enquadrar comportamentos corriqueiros relativos à pornografia infantil, mormente no âmbito da Internet - deve-se lembrar que à época da promulgação do ECA não existia previsão legal a englobar as novas circunstâncias fáticas decorrentes do incremento das tecnologias digitais -, o legislador resolveu reformar a lei brasileira para possibilitar a inclusão dessas hipóteses.

Por isso, por meio da Lei 10.764/2003, modificaram-se os artigos. O primeiro dispositivo aumentou a abrangência do alcance do tipo, criminalizando a produção "por qualquer outro meio visual" de fotografias ou vídeos nos quais seja utilizada criança ou adolescente, além de prever reprovabilidade idêntica para casos em que a peça gerasse vexame para o menor. De seu lado, o segundo artigo sofreu alterações quanto aos núcleos do tipo, acrescentando-se as condutas de "apresentar", "vender", "fornecer" e "divulgar", todos relacionados com imagens ou cenas de sexo explícito envolvendo criança ou adolescente. ${ }^{241}$

Mais recentemente, buscando dar ainda mais vazão à supracitada tendência em nível mundial de aumento no rigor e na repressão a delitos de abuso de crianças e a práticas de turismo sexual envolvendo crianças e adolescentes - mormente os praticados por meio da rede mundial de computadores ${ }^{242}$-, e premido pelo relatório da apelidada "Comissão Parlamentar de Inquérito Mista da Pedofilia”, o legislador brasileiro aprovou nova mudança do ECA, acarretando um maior recrudescimento dos crimes e das penas.

Nesse contexto, aparece a Lei 11.829/2008, que resultou em uma verdadeira revolução incriminadora, acarretando, além do aumento vertiginoso dos comportamentos incrimináveis relativos à distribuição, venda, envio etc. de pornografia infantil - e das sanções previstas, estendeu-se a criminalização a condutas antes atípicas, como a mera posse ou armazenamento

\footnotetext{
${ }^{241}$ SYDOW, Spencer Toth. Pedofilia virtual e considerações críticas sobre a Lei 11.829/08. Revista Liberdades $n^{o}$ 1. São Paulo: Instituto Brasileiro de Ciências Criminais, p. 48-49, mai-ago 2009.

${ }^{242}$ A preocupação com a repressão a todas as condutas que, de alguma forma, contribuam ou alimentem a difusão de arquivos (fotos ou vídeos) com representação sexual de crianças e adolescentes vem aumentando bastante desde o final do século passado. O rigor das legislações no mundo inteiro, conforme já destacado acima, salta aos olhos.
} 
de material pornográfico, bem como a mera simulação ou montagem de arquivos (de qualquer espécie) envolvendo crianças e adolescentes. ${ }^{243}$

O exame sobre a eventual legitimação dos tipos penais previstos no ECA relativos aos variados comportamentos envolvendo material pornográfico infantil será feito mais adiante. Entretanto, desde logo, e naquilo que importa ao objeto da presente dissertação, já vale transcrever as considerações de SPENCER TOTH SIDOW no tocante à incompatibilidade da figura delitiva do artigo 241-C com os ditames constitucionais: "o artigo 241-C, também preocupa, pois torna típica a ação de simular a participação de criança ou adolescente em cena de sexo explícito ou pornográfica por meio de adulteração, montagem ou modificação de fotografia, vídeo ou qualquer outra forma de representação visual, apenando o agente com um a três anos de reclusão e multa. $\mathrm{O}$ direito penal passa a considerar relevante e penalmente

\footnotetext{
${ }^{243}$ A redação vigente dos tipos penais que interessam ficou da seguinte forma:

“Art. 241. Vender ou expor à venda fotografia, vídeo ou outro registro que contenha cena de sexo explícito ou pornográfica envolvendo criança ou adolescente:

Pena - reclusão, de 4 (quatro) a 8 (oito) anos, e multa.

Art. 241-A. Oferecer, trocar, disponibilizar, transmitir, distribuir, publicar ou divulgar por qualquer meio, inclusive por meio de sistema de informática ou telemático, fotografia, vídeo ou outro registro que contenha cena de sexo explícito ou pornográfica envolvendo criança ou adolescente: Pena - reclusão, de 3 (três) a 6 (seis) anos, e multa.

§1o Nas mesmas penas incorre quem:

I - assegura os meios ou serviços para o armazenamento das fotografias, cenas ou imagens de que trata o caput deste artigo;

II - assegura, por qualquer meio, o acesso por rede de computadores às fotografias, cenas ou imagens de que trata o caput deste artigo.

(...)

Art. 241-B. Adquirir, possuir ou armazenar, por qualquer meio, fotografia, vídeo ou outra forma de registro que contenha cena de sexo explícito ou pornográfica envolvendo criança ou adolescente:

Pena - reclusão, de 1 (um) a 4 (quatro) anos, e multa.

$\S 1$ o A pena é diminuída de 1 (um) a 2/3 (dois terços) se de pequena quantidade o material a que se refere o caput deste artigo.

$\S 20$ Não há crime se a posse ou o armazenamento tem a finalidade de comunicar às autoridades competentes a ocorrência das condutas descritas nos arts. 240, 241, 241-A e 241-C desta Lei, quando a comunicação for feita por:

I - agente público no exercício de suas funções;

II - membro de entidade, legalmente constituída, que inclua, entre suas finalidades institucionais, o recebimento, o processamento e o encaminhamento de notícia dos crimes referidos neste parágrafo;

III - representante legal e funcionários responsáveis de provedor de acesso ou serviço prestado por meio de rede de computadores, até o recebimento do material relativo à notícia feita à autoridade policial, ao Ministério Público ou ao Poder Judiciário.

$\S 3 o$ As pessoas referidas no $\$ 2$ o deste artigo deverão manter sob sigilo o material ilícito referido.

Art. 241-C. Simular a participação de criança ou adolescente em cena de sexo explícito ou pornográfica por meio de adulteração, montagem ou modificação de fotografia, vídeo ou qualquer outra forma de representação visual: Pena-reclusão, de 1 (um) a 3 (três) anos, e multa. (Incluído pela Lei $n^{\circ} 11.829$, de 2008)

Parágrafo único. Incorre nas mesmas penas quem vende, expõe à venda, disponibiliza, distribui, publica ou divulga por qualquer meio, adquire, possui ou armazena o material produzido na forma do caput deste artigo."
} 
punível a conduta que não utiliza criança nem adolescente, mas insinua a participação, em cena de sexo explícito. Afrontando o Princípio da Ofensividade - pois não há vítima direta nem violação de bem jurídico material per si - torna punível a conduta de criação de pseudomídias, restringindo a liberdade de expressão, a produção artística, a produção literária e assim por diante. O tipo não discrimina qualquer tipo de mídia, englobando fotografia, vídeo ou qualquer representação visual (leia-se, escultura, livros, quadros, revistas, gibis etc.) e cria uma nova regra na sociedade: há possibilidade de restrições de criação e, pois, restrições no direito de informar". 244

Ainda sob um enfoque crítico, cabe mencionar o raciocínio de ALEXANDRE ASSUNÇÃO E SILVA - ao qual adere o presente trabalho - no sentindo de que, a despeito do inequívoco repúdio à produção, venda, distribuição ou divulgação de material pornográfico infantil por qualquer meio (sendo favorável à sua criminalização), "a nova redação dada pela Lei 11.829/2008 a alguns tipos penais não obedeceu ao princípio constitucional da proporcionalidade; além disso, ela criou crimes que violam outros princípios constitucionais e de direito penal". 245

Com efeito, afora a imensa desproporcionalidade decorrente da ausência de diferenciação entre as situações de utilização de crianças (até doze anos) e adolescentes (entre doze e dezoito anos) nas filmagens ou fotos, a decisão legislativa de incriminar a mera simulação de menores em contexto sexual também resulta exagerado, despropositado, quando se tem em mente os critérios de lesividade/ofensividade.

\footnotetext{
${ }^{244}$ Ob. cit., p. 55-56. Na mesma toada segue a análise de PEDRO PAULO FERREIRA, em obra dedicada à pornografia infantil simulada, segundo a qual "seguindo o espírito da Lei 11.829 , vê-se que a intenção é a tutela penal da dignidade sexual de crianças e adolescentes. Contudo, razoável perceber que em nada protege o bem jurídico o tipo do artigo 241-C, pois em nenhuma circunstância é capaz a conduta incriminada de oferecer dano efetivo ou risco iminente ao referido bem jurídico." E completa: "na maioria das vezes, utiliza-se em grande escala da tipificação de figuras sob a categoria de crimes de perigo abstrato e de mera conduta. Neste caso, a predileção pela incriminação do comportamento do artigo 241-C sob a tipologia de perigo presumido, busca antecipar a punibilidade, na crença de que isso possa salvaguardar o bem jurídico de forma mais eficaz. Pela análise dessa tessitura, vê-se que o Direito Penal caminha a passos largos rumo à expansão da legitimação do jus puniendi a campos que indiscutivelmente deveriam figurar como indiferentes penais. Certamente, no caso da Lei 11.829/2008, a ampliação do direito repressivo se baseia na necessidade de modernizá-lo, para fazer frente aos reclames advindos da chamada sociedade de risco." Artigo 241-C da Lei $\mathrm{n}^{\circ}$ 11.829/2008: a pornografia simulada..., p. 19.

${ }^{245}$ Violações a princípios..., ob. cit., p. 446-447.
} 
Ademais, outros aspectos interessantes atinentes às figuras jurídicas relacionadas com a pornografia infantil - como a questão da pequena quantidade e o mero acesso a esse material - também serão abordados como forma de estabelecer critérios seguros de aplicação do direito penal a esses casos.

Em resumo, ao recrudescer as penas, criar novas hipóteses de incidência e estender a tipificação para casos em que haja a singela posse de material pornográfico infantil simulado, a legislação brasileira sobre a matéria pode ser considerada uma das mais rigorosas, pois, como já destacado, na legislação espanhola, apena-se somente a posse desse tipo de material virtual com a finalidade de tráfico ou difusão.

\subsection{O tráfico, a aquisição, a posse e o armazenamento desse tipo de material}

O primeiro grupo de tipos penais de relevo relativos à pornografia infantil que merece menção atina com as condutas mais reprováveis e lesivas ao bem jurídico tutelado, quais sejam aquelas ligadas ao tráfico desse material. São comportamentos de alguma forma relacionados com o contexto industrial de produção, divulgação, distribuição, venda e propagação, ainda que gratuitamente, de documentos contendo crianças e jovens abaixo dos dezoito anos em contexto libidinoso (pornografia infantil real).

Muito embora essa modalidade criminosa não seja o foco principal do estudo - que recai, como se nota, sobre os delitos de posse -, surgem algumas questões interessantes a respeito dos aspectos jurídicos intrínsecos ao tema.

Desde logo, há um detalhe que leva à reflexão: a patente desproporcionalidade dos preceitos secundários dos tipos penais determinados pelos artigos 240, 241, caput, e 241-A, da Lei n. ${ }^{\circ} 8.069 / 90$, quando se está em lume a participação de menores até catorze anos ou entre catorze e dezoito anos. 
Com efeito, basta checar as sanções penais delineadas para esses casos para se verificar a clara falta de critérios de proporcionalidade das respostas penais. De um lado, aparecem as figuras mais reprováveis - 'produção, reprodução, direção, fotografia ou registro de cena de sexo explícito ou pornográfica envolvendo criança ou adolescente' (art. 240 do ECA) ou 'venda, exposição à venda de fotografia, vídeo ou outro registro' nessas condições (art. 241, caput, do ECA) - com pena de quatro a oito anos de reclusão. De outro, o ECA estabelece sanção para o caso de 'oferecimento, troca, disponibilização, transmissão ou distribuição' de pornografia infantil com criança ou adolescente (art. 241-A do ECA) de três a seis anos de reclusão.

Veja-se que, pela redação dos tipos, inexiste qualquer diferenciação da quantidade de pena se os envolvidos são crianças ou adolescentes, havendo uma equiparação legal desses grupos de indivíduos na condição de protegidos pela norma penal. Em outros termos, a lei penal não teve o cuidado de diferenciar as situações por algum critério etário, jogando na mesma vala tanto a utilização de uma criança de cinco anos de idade quanto a de um adolescente às voltas de completar dezoito anos.

Diante disso, haveria respeito ao princípio da proporcionalidade somente quando os ofendidos ostentassem idade até catorze anos, já que as sanções proscritas para o tráfico de dito material guardam certa relação com as penas dos crimes descritos nos artigos 213 , par. $1^{\circ}$ e 217-A, ambos do Código Penal, visto que nestes dois casos a pena mínima é de oito anos de reclusão, bem superior à dos crimes previstos no ECA. Isto é, quando se analisa a responsabilidade dos agentes que traficam pornografia infantil (sujeitos a pena mínima de quatro anos) com aqueles que efetivamente abusaram ou exploraram os menores, verifica-se que elas guardam uma proporção.

Na hipótese, contudo, de pornografia que retrate adolescentes maiores de catorze anos - desde que ausentes indícios de violência sexual ou exploração social (por meio de prostituição, por exemplo) -, o princípio da proporcionalidade fica violado. 
Isso porque, nos dizeres de ALEXANDRE ASSUNÇÃO E SILVA, os mencionados artigos do ECA não fazem qualquer menção sobre o adolescente ter sido forçado à produção das cenas (levando à conclusão de que, para o legislador, tal dado seria indiferente), motivo pelo qual se conclui que mesmo nos casos de participação voluntária e consentida de um adolescente maior de catorze anos, haverá a incidência dos tipos penais. No entanto, pelo CP brasileiro, manter relação sexual consentida com um indivíduo dessa idade, exceto nos casos de exploração ou prostituição, é fato atípico. ${ }^{246}$

Ora, a desproporção gerada por essa situação salta aos olhos, pois é possível imaginar uma hipótese em que o indivíduo que participa de cenas de sexo explícito com uma adolescente de dezesseis anos não receba pena alguma (se não houver violência ou exploração), ao passo que aquele que divulga o material responda por delito cuja pena mínima é de quatro anos de reclusão. Como se nota, nada mais desproporcional.

Consoante esse entendimento doutrinário, do qual se compartilha, "é compreensível que o legislador queira evitar a realização de pornografia com adolescentes, como meio de previnir que estes sejam levados à prostituição. Como, via de regra, não se pode saber, através da visualização das imagens produzidas, se o adolescente que atuou na sua realização estava se prostituindo, a produção desse tipo de pornografia pode ser desestimulada pela lei penal, porque o favorecimento à prostituição de adolescentes é considerado crime, como já visto. Contudo, em razão da ausência de proibição legal, não há ilicitude na prática de ato sexual consentido com maiores de catorze anos não prostituídos. Assim, a produção, venda ou divulgação de material pornográfico envolvendo adolescentes nessa situação deve receber tratamento similar à pornografia envolvendo adultos, tipificada no art. 234 do CP.,"247

\footnotetext{
${ }^{246}$ Segundo o autor, "antes da Lei 12.15/2009, quem praticasse ato libidinoso com pessoa maior de 14 e menor de 18 anos, corompendo ou facilitando sua corrupção cometia o delito de corrupção de menores, previsto no art. 218 do CP." Contudo, após a alteração, esse dispositivo prevê a incriminação apenas quando a vítima for menor de catorze anos. "Assim, a partir da vigência da Lei 12.015/2009, quem praticar ato sexual ou libidinoso de maneira consentida com pessoa entre 14 e 18 anos que não esteja sendo explorada sexualmente pela prostituição ou de outra forma (talvez o lenocínio de alguém maior de 14 e menor de 18 anos, previsto no art. 227 , par. $1^{\circ}$, do CP), não pratica crime algum. Ocorre que tal situação contrasta totalmente com as penas previstas nos arts. 240, 241, 241-A do ECA, de quatro a oito anos de reclusão, para quem produz ou vende pornografia envolvendo criança ou adolescente". (Ob. cit., p. 448).

${ }^{247}$ Ob. cit., p. 449. Aqui, porém, há apenas um adendo: conforme já destacado em capítulo anterior, a conduta de escrito pornográfico, a nosso ver, merece ser descriminalizada (aliás, nos moldes do Anteprojeto de $\mathrm{CP}$ ). Nesse caso, então, ao contrário da opinião do mencionado autor, o ideal seria considerar a conduta como sendo atípica,
} 
Em resumo, em face do princípio da proporcionalidade, o Poder Judiciário, nessas situações, estaria autorizado a, mesmo em desfecho condenatório, aplicar a pena do mencionado art. 234 do CP (seis meses a dois anos de reclusão) quando o menor retratado for adolescente acima de catorze anos, sem indícios da prática de estupro. Nesse contexto, tanto a idade da pessoa quanto a existência de violência ou coação serão aferidas por meio de perícia e pela análise do contexto das imagens. ${ }^{248}$

Outra relevante questão decorrente do delito de tráfico de material pornográfico infantil reside na ofensa ao princípio do ne bis in idem nos casos em que houver a sobreposição da figura do indivíduo que contracena com o menor e, ao mesmo tempo, produz material pornográfico infantil.

De acordo com o parágrafo $1^{\circ}$ do artigo 240 do ECA, incorre nas mesmas penas de quem produz ou participa de pornografia infantil aquele que contracena com as crianças ou adolescentes envolvidos. Entretanto, quem contracena com menores de catorze anos deve responder pelo grave delito de estupro de vulnerável (art. 217-A do CP). Nesse caso, se o agente também responder pelo crime de tráfico de pornografia infantil, haverá claro bis in idem, pois lhe serão impostas duas penas pelo mesmo fato, o que é incondizente com o texto constitucional.

Assim, quem somente contracena com o menor, sem praticar as outras condutas legais, não deve ter seu comportamento incurso nas penas do mencionado art. 240 do ECA, bastando que responda pelo delito de estupro (se houver constrangimento e a vítima tiver entre catorze e dezoito anos), estupro de vulnerável (no caso de vítima menor de catorze anos) ou exploração sexual de vulnerável submetido à prostituição. ${ }^{249}$

\footnotetext{
ou então que se preveja um tipo penal parecido com o exibicionismo, previsto no CP espanhol. De todo modo, a aplicação do art. 240 e 241-A para essas hipóteses parece descabida, diante da aventada desproporcionalidade.

${ }^{248}$ Cf. ASSUNÇÃO e SILVA, Alexandre, ob. cit., p. 451-452.

${ }^{249}$ Cf. ASSUNÇÃO e SILVA, Alexandre, ob. cit., p. 452.
} 
Adiantando a análise, convém agora abordar o delito de aquisição, posse ou armazenamento de pornografia infantil (previsto no artigo 241-B do ECA). Esse tipo penal busca punir o comportamento daqueles que adquirem, possuem ou armazenam, a qualquer título e por qualquer meio, arquivos contendo representações gráficas ou audiovisuais com menores nas mesmas condições já estudadas no tópico anterior. ${ }^{250}$ Várias são as questões relevantes nesse âmbito.

No tocante ao conceito de posse, o tipo penal requer a concorrência dos seguintes elementos: a) uma posse de material pornográfico em cuja elaboração se tenham utilizado menores dentro de um cenário sexual; b) que esse material tenha uso pessoal aos armazenadores, excluindo-se quaisquer atividades relacionadas com a sua difusão ou distribuição (ou seja, não pode haver elementos demonstrativos de produção, venda, exibição ou facilitação dessas atividades por qualquer meio) ou até mesmo a posse com esses escopos; c) o elemento subjetivo do injusto, constituído pelo dolo do agente, bastando a mera consciência de que se possuem tais dados em seus arquivos ${ }^{251}$.

A ideia é justamente criminalizar o comportamento que exprima o desejo de manter a posse do material, para uso pessoal e privado, sem intenção ou mesmo consumação da disseminação do material por qualquer meio (principalmente os telemáticos, na realidade atual).

Finalmente, um último dado interessante a respeito da figura delitiva prevista no artigo 241-B do ECA (posse de pornografia infantil real) diz com a questão dos efeitos jurídicos da pouca quantidade desse material.

\footnotetext{
250 JOSE MIGUEL CORTINA faz menção a interessante expressão apropriada pela doutrina e jurisprudência espanholas para definir esse tipo de crime: "delito solitário" Cf. sentença do Supremo Tribunal da Espanha STS 1055/2009, de 3 de novembro, ob. cit., p. 89. Daí já é possível ter uma ideia da peculiaridade desse injusto penal, qual seja, a ausência de obrigatoriedade de inter-relação entre o consumidor e o "traficante" do material, bastando para a consumação do crime o contato solitário do possuidor com o material adquirido, o que deixa transparecer o nítido distanciamento entre a conduta e a lesão ao bem jurídico "bem-estar do menor".

${ }^{251}$ Importa notar que o dolo da conduta de possuir, ante às alegações relativas à possibilidade de download por erro, pode ser afirmado por meio de prova indiciária: quando haja transferência de arquivos para outras unidades de armazenamento alheias ao computador do agente, quando o histórico de busca reflita um propósito de permanência desse tipo de material, como o número de arquivos armazenados.
} 
Enquanto a lei, nesse ponto, prevê uma causa de diminuição de pena $(1 / 3$ a $2 / 3$ de redução), se se verificar uma ínfima quantidade de imagens ou arquivos (art. 241-B, par. $1^{\circ}$, do ECA), há entendimento no sentido da aplicação do princípio da insignificância, tal como ocorre em outros tipos delituosos (descaminho, crime contra a ordem tributária e furto, v.g.). ${ }^{252}$

De outro lado, CAMILA GARCIA E SILVA destaca a divergência jurisprudencial sobre o que deve ser considerada quantidade ínfima, de modo que "tanto o réu que possuía 50 fotos, quanto outro que detinha mais de 60.000 arquivos pornográficos em seu computador, foram considerados possuidores de grande quantidade de fotos, mas o segundo possuía cerca de dez mil vezes mais obras libidinosas envolvendo crianças e adolescentes."253

Prosseguindo em nossa análise, antes de abordar os aspectos jurídicos informadores da disciplina penal, ainda com relação ao tipo objetivo dos delitos atinentes à pornografia infantil, além da aquisição, armazenamento ou disposição de tais materiais, outra importante discussão se coloca a respeito da possibilidade de equiparação entre essas condutas e o fato de o agente apenas acessar ou visualizar o conteúdo ilícito.

\subsubsection{O mero acesso a arquivos como figura análoga à da posse de pornografia infantil}

Como não poderia deixar de ser, os avanços tecnológicos acarretam problemas aos operadores jurídicos que se debruçam sobre a realidade fática, quando do exame de casos concretos que, apesar de não se subsumirem automaticamente aos textos legais, suscitam dúvidas sobre a configuração (ou não) do delito em análise.

\footnotetext{
${ }^{252}$ Essa é a tomada de posição de ALEXANDRE ASSUNÇÃO E SILVA, ob. cit., p. 455-456.

${ }^{253}$ Vide os precedentes do TJSP, AP 0096559-93.2005.8.26.0050, rel. Francisco Bruno, j. 30.06.2011 (50 fotos) e TRF-3, ACR 2008.61.10.011973-6, rel. Antonio Cedenho, DJF3 27.07.2011, p. 315 (60 mil arquivos). Ob. cit., p. 253.
} 
Esse tema reveste-se de relevância na medida em que se observa um dado importante: a esmagadora maioria dos ordenamentos invocados até aqui ${ }^{254}$ incrimina a "aquisição" ou "detenção" desse tipo de material; entretanto, a lei não fala em visualização ou em "consulta a tal material".

Por isso, vale transcrever a opinião de JOSÉ MOURAZ LOPES, que diferencia as situações, de modo a afastar o caráter ilícito da conduta de mera consulta do material, o que, consoante os critérios da estrita legalidade, não se encaixa na previsão legal, principalmente no âmbito da Internet: "trata-se aqui de proibir a detenção ou posse e não a consulta ou visionamento, nomeadamente quando se trata de material pornográfico que circula no espaço virtual ou digital. Questão complexa poderá suscitar-se com o facto de, no domínio da pornografia visualizada via internet, esse acto de visualização - que não é crime, repete-se implicar desde logo e automaticamente uma 'descarga' do material para o disco do computador que aí fica. Certamente nestas condições dificilmente será de concluir pela concretização do tipo de crime se se não se verificar a questão do tipo de culpa subjetivo, v.g., a existência do dolo." 255

Esse mesmo raciocínio é compartilhado por alguns autores espanhóis ${ }^{256}$, podendo ser destacado o ponto de vista de BOLDOVA PASAMAR, para quem, apesar de não guardar relação de necessidade com a web, esse aspecto tem relevância agora para destacar que o simples download para a visualização de pornografia infantil não constitui "posse" se o agente deixa de guardar de algum modo o arquivo ou documento para posterior utilização.

Com isso, tem lugar a conclusão segundo a qual o acesso à pornografia não é equivalente à conduta de a possuir (tampouco o é dispor de senhas ou chaves criptografadas

\footnotetext{
${ }^{254}$ Excetuam-se, por exemplo, as legislações alemã e italiana, além da norte-americana, conforme se apontará a seguir.$$
{ }^{255} \text { Ob. cit., p. } 159 .
$$$$
{ }^{256} \text { Exemplificadamente, ORTS BERENGUER, ÚBEDA DE LOS COBOS e ESQUINAS VALDERDE. Apud }
$$$$
\text { BOLDOVA PASAMAR, Miguel, ob. cit., p. 56, nota } 50 .
$$ 
para facilitar o acesso restrito), muito embora tanto um comportamento quanto o outro sejam ou constituam atos de consumo. ${ }^{257}$

Com efeito, ao empregar os núcleos de adquirir, armazenar e possuir, o tipo penal em comento não faz referência expressa ao mero acesso dessas imagens em meios digitais, o que se poderia pressupor a imprescindibilidade do elemento subjetivo configurado na intenção de "permanecer" com o dito material. Isto é, o fundamento primordial da incriminação seria o de evitar o armazenamento de arquivos com o propósito de dispor, a qualquer momento, daqueles documentos.

Entra em cena a exegese pela qual a o conceito de posse implica uma detenção prolongada temporalmente do material, o que, em termos de Internet, reclamaria a correspondente descarga do arquivo, com o fim de se protrair no tempo. ${ }^{258}$

Muito embora o texto legal não seja explícito, presume-se a intenção do legislador, ao incriminar a posse, de dissuadir os usuários de encaminhar, compartilhar e, por conseguinte, difundir os materiais pornográficos infantis. Afinal, parece claro, aquele que guarda ou armazena pornografia infantil, aos olhos da lei penal, representa um risco maior à coletividade do que o agente que apenas acessa o material, à exata medida que a facilidade de disposição do material é mais evidente naquelas hipóteses. Para isso, o fato de a aquisição prorrogar-se no tempo é mais compatível com os critérios de proteção do bem jurídico eleito pelo legislador do que a efêmera visualização.

Essa é a posição de CAMILA GARCIA DA SILVA, segundo quem haveria uma lacuna da lei, devendo ter sido contemplada também a hipótese de mera visualização, já que “o critério da regularidade ou habitualidade com que se dá o acesso é fundamental para a criminalização dessa conduta. O sujeito pode entrar nesses sites por erro ou por curiosidade,

257 BOLDOVA PASAMAR, Miguel Ángel. Pornografía infantil en la red. Fundamento y límite de la intervención del Derecho Penal. Cidade do México: Ubijus, 2008, p. 56.

${ }^{258}$ Nesse diapasão, mostram-se pertinentes as palavras de FERNÁNDEZ TERUELO segundo as quais "la exigencia de posesión excluye la tipicidad de la mera visualización de pornografia infantil por lo que, en realidad, no se sanciona penalmente el consumo, sino la acumulación de estos materiales. Será necesario que el sujeto realice algo más que la mera visualización (normalmente la descarga) que le permita poder visualizar los materiales cuando lo desee sin volver a conectarse a la Red." Derecho penal e internet..., p. 139. 
uma vez ou até mesmo algumas vezes em grandes intervalos temporais, mas se em seu histórico sempre há registros dessas atividades, deve existir uma punição, pois há um dano social, já que crianças ou adolescentes reais têm sua liberdade e dignidade sexual feridas cada vez que suas fotos ou vídeos são exibidos". 259

Prossegue a autora asseverando que "portanto, o agente que assiste on line e com frequência ao conteúdo pornográfico qualificado tem conduta tão reprovável quanto aquele que baixa esses materiais. Há uma lacuna na lei, uma vez que condutas muito semelhantes são tratadas de formas diversas ou até mesmo ações menos reprováveis são tuteladas pelo direito penal (como nos casos de simulação técnica em estilo fantasia". Ao final, propõe que "se o legislador conferiu uma proteção integral à criança e ao adolescente (...) há que se pensar acerca da criação de um tipo sobre a simples navegação habitual em sites que contenham obras libidinosas envolvendo jovens". ${ }^{260}$

Sob outro ângulo, é lícito afirmar que a exigência de posse afasta a tipicidade da mera visualização de pornografia infantil, justamente porque, em verdade, não se pune, necessariamente, na esfera penal, o mero consumo ${ }^{261}$. Ao revés, se está a apontar como escopo primário da incriminação a acumulação desses materiais.

Isto é, repita-se, o caráter de fácil acessibilidade (ou disposição) do material acaba atribuindo à conduta uma relevância de cunho criminal. O fato de o material "estar à mão" do agente, no momento em que bem desejar, revela o risco inerente a tais condutas e que deve ser reprimido pela sanção penal.

Afinal de contas, sustentar posição diferente dessa - ou seja, de que o elementar contato visual com o material, na tela do computador já bastaria à subsunção à dita figura

\footnotetext{
${ }^{259}$ Ob. cit., p. 261.

${ }^{260}$ Idem.

${ }^{261}$ Claro que a ideia, aqui, é a busca do resguardo ao princípio da estrita legalidade. E a rigor, realmente os tipos penais, nos ordenamentos jurídicos do mundo ocidental, mencionam apenas os núcleos "adquirir", "armazenar" ou "possuir".
} 
delitiva $^{262}$ - parece questionável e temerário pois poderia incidir em hipóteses de duvidosa configuração, considerando as possibilidades de acesso que a rede oferece e considerando as possibilidades ilimitadas de difusão decorrentes de uma só cópia de arquivo.

$\mathrm{Na}$ contramão de todos esses argumentos, cabe ressalvar que modelos legislativos decorrentes de Congressos Internacionais cujo foco é a proteção de crianças exploradas advogam a opinião pela qual deveria ser castigada não apenas a descarga desses arquivos, mas também a simples visualização. Essa é a proposta decorrente, por exemplo, do International Centre for Missing \& Exploited Children, conforme os termos de uma Lei-Modelo pensada para disciplinar a questão da pornografia infantil. ${ }^{263}$

Convém abrir um breve parêntese para examinar duas questões subjacentes relacionadas com o acesso ao material proibido: $i$ ) o avanço de algumas legislações europeias, como na Itália e na Alemanha (dois importantes Estados liberais) - de duvidosa constitucionalidade, diga-se - de considerar ilícita não apenas a posse, como também a mera procura por pornografia infantil e ii) as cautelas devidas, quando da análise de casos concretos, no que atina com a intenção do agente (dolo de acessar os documentos).

Com relação ao primeiro aspecto, entende-se que a busca ou o interesse a essa classe de material estariam restritos à esfera de "atos prévios" ou de "consumo incompleto" de pornografia, devendo ser encarados como irrelevantes penais, ficando no vago campo das cogitações ou dos atos preparatórios (estes, sabidamente impuníveis sob a égide do Direito

\footnotetext{
${ }^{262}$ É importante destacar que existe posição doutrinária favorável à criminalização da mera visualização de material pornográfico infantil. Conforme a opinião de WORTLEY e SMALLBONBE, "possession of (not just a production and trading of) child pornography is an offense. In the case of the Internet, images do not have to be saved for an offense to have occurred - they simply need to have been accessed." (WORTLEY, Richard and SMALLBONE, Stephen "Child Pornography on the Internet". Problem-Oriented Guides for Police, disponível em http://www.cops.usdoj.gov/Publications/e04062000.pdf, acesso em 21 de outubro de 2012. Aliás, a lei norteamericana já tipifica o mero acesso, desde que o agente tenha conhecimento do conteúdo do arquivo ("Knowingly accessing child pornography with the intent to view it" (18 U.S.C. par. 225-A-'a', 'B').

${ }^{263}$ Cf. Relatório do ICMEC já citado. Essa foi a mesma linha trilhada pelo Convênio do Conselho da Europa (Conselho de Lanzarote, realizado em outubro de 2007), cujo teor do artigo 20.1.'f' deixa claro que cada Estadoparte adotará as medidas legislativas que sejam necessárias para tipificar como delito as seguintes condutas intencionais, quando se cometam de forma ilícita...f) o acesso à pornografia infantil, com conhecimento de causa e por meio das tecnologias da informação e da comunicação. (cf. CORTINA, José Miguel. Ob. cit., p. 101. A Declaração do III Congresso Mundial do Rio de Janeiro, no ponto II.4., também sustenta a tipificação do mero acesso a pornografia infantil.
} 
Penal do Fato). A incriminação, nessa esteira, caracterizaria indevida, demasiada e perigosa antecipação de punição, incompatível com o princípio da estrita proteção de bens jurídicos, no sentido material, em um Estado de Direito.

Isso porque, a admitir-se a punição de quem somente busca pornografia infantil estarse-ia diante de situação contraditória e desproporcional, já que se legitimaria a punição do pensamento, sem qualquer mudança no mundo fenomênico. A gigantesca distância entre os interesses dos menores tutelados e o comportamento de procurar pelo material revelaria um enorme contrassenso, pois se produziria o delito inclusive sem ter havido a visualização das imagens, sem afetação, portanto, sequer à intimidade do menor ou menores que aparecem nelas.

Diante desse quadro, ao analisar o alcance do tipo penal de posse de material pornográfico infantil, cabe lembrar que, para que a conduta seja punível, a ação de busca desse conteúdo deve ser levada a cabo com êxito, devendo ficar extramuros do tipo a procura infrutífera. Por isso, não haveria que se falar, ao menos na maioria dos sistemas europeus e também no Brasil, na possibilidade de configuração da modalidade tentada dessa figura delitiva. ${ }^{264}$

Já no que atina com o segundo aspecto que tangencia o tema do acesso a arquivos digitais de conteúdo pornográfico infantil, há de se enxergar de modo criterioso e cauteloso tais condutas, uma vez que, como é cediço, a possibilidade de haver mal-entendidos é considerável, diante de eventuais induções que os meios telemáticos produzam no usuário da rede mundial de computadores.

Com efeito, o funcionamento autônomo dos meios informáticos conjugado com a gestão igualmente autônoma da rede - às vezes, há redirecionamentos automáticos para

\footnotetext{
${ }^{264}$ Essa é a opinião expressada por JOSÉ MIGUEL CORTINA, ob. cit., p. 104. A propósito, ESQUINAS VALVERDE também comunga da tese segundo a qual é ainda mais criticável a possibilidade, prevista na legislação alemã, de sancionar com a pena da consumação inclusive a tentativa de obter o material pornográfico, de modo que já a busca (inclusas aí aquelas que resultarem frustradas) das correspondentes páginas na Internet poderia ser vista como um imediato início de execução. (ob. cit., p. 217).
} 
páginas da web onde existem cópias temporárias de arquivos - podem implicar a posse por se verificar armazenada, de forma involuntária, uma forma virtual de detenção de tal material.

Por óbvio que, nessas hipóteses, em razão da ausência do elemento subjetivo de possuir para uso próprio, não há que se falar na configuração de delitos que tais. Porém, exsurge daí uma inquietante situação na qual se pode erigir à categoria de crime comportamentos involuntários (até mesmo acidentais) por parte de usuários da Internet que, são, na sua imensa maioria, pessoas leigas em assuntos informáticos.

Bem por isso, ALEXANDRE RAMALHO DE FREITAS, em obra dedicada à análise das influências normativas europeias sobre a forma de países (principalmente a Espanha) tratarem a pornografia infantil, destaca que se deve examinar a questão da prova do dolo do possuidor dessa classe de materiais. Alerta o apontado autor que, "além da difícil prova da finalidade da posse (distribuição ou autoconsumo), (...) sempre existirão problemas para demonstrar que o sujeito sabia realmente que o que teria era um material de pornografia infantil, já que sempre poderá alegar, por exemplo, que desconhecia a idade das pessoas que tomavam parte em ditos materiais". 265

Sem embargo de tais dificuldades, é essencial apurar, sempre que possível e seguindo os ditames do devido processo legal, o real móvel do agente, por meio de um trabalho de levantamento de elementos indiciários, de ordem objetiva, que apontem para a consciência livre da conduta de posse. Então, por exemplo, a quantidade de arquivos, a forma de armazenamento, a organização topográfica de documentos digitais em pastas com nomes sugestivos (porn kids ou expressões que tais), histórico de acessos e visualizações, anterior compartilhamento comprovado pericialmente, todas essas condutas serão avaliadas como suficientes (ou não) a configurar o elemento subjetivo do tipo no caso concreto.

Por esses motivos, conforme já sublinhado acima, deve-se alertar que parece adequado exigir, para a configuração do delito de posse para uso próprio, que se suponha uma dada

\footnotetext{
${ }^{265}$ FARIAS, Alexandre Ramalho de. A incidência da normativa internacional na delimitação do bem jurídico protegido nos delitos relativos à pornografia infantil. Revista Justiça e Sistema Criminal, Curitiba, v. 2, n. ${ }^{\circ} 3$, jul./dez., 2010, p. 179.
} 
perduração da detenção desse peculiar grupo de material virtual, sob pena de desvirtuamento da própria finalidade da norma de evitar a sua proliferação na rede. ${ }^{266}$

Para tanto, BOLDOVA PASAMAR perfila algumas interessantes situações que dão guarida à tese de que uma posse efêmera ou episódica não deve ser entendida como delituosa: i) quando, por exemplo, se imprime uma imagem e, posteriormente, após a visualização, se destrói tal material; ii) na hipótese de o agente "baixar" os arquivos das imagens ou filmes em seu computador e, na sequência, se apaga ou elimina os dados do computador; iii) se alguém escuta ou vê algum arquivo sem a necessidade de descarga das informações no computador pessoal do agente.

Seguindo-se o mesmo raciocínio, infere o autor que tampouco será crime a conduta de adquirir sem visualizar ou mesmo a mera busca do material, consoante já abordado. Nessas hipóteses, assim como nas outras trazidas como exemplos, não houve um "uso mínimo" consciente daquelas imagens ou vídeos, afastando-se, assim, o caráter ilícito do comportamento. ${ }^{267}$

De todo modo, tanto nos casos de acesso deliberado ou acidental desse tipo de material, diante da falta de nexo direto entre tais condutas e o objeto de proteção da norma, verifica-se que a mera posse está muito distante de relacionar-se com o menoscabo sexual de menores ou incapazes, ou seja, que sirva de estímulo ao consumidor para chegar a realizar ele mesmo alguma fantasia sexual com menores reais.

Como esse dado empírico - perigo de transformação da conduta de acessar tais materiais e a exteriorização de abusos na "vida real" - não está presente de forma apriorística

\footnotetext{
${ }^{266}$ A imprescindibilidade de um sentido finalístico concreto para a caracterização do injusto penal, voltado para o estímulo sexual do espectador ou então para a posterior distribuição ou difusão na rede mundial de computadores, é defendida por outros autores espanhóis. A reiteração ou qualquer outra demonstração de vontade de manter e compartilhar o material são elementos essenciais à prática delituosa. Assim, FERNÁNDEZ TERUELO aponta que a punição da mera posse deveria levar em conta a presença de algum requisito a mais, um plus, como por exemplo, certa reiteração que evidencie a real intenção do agente, bem como a aptidão da conduta de promover, efetivamente, a oferta desses materiais. Ob. cit., p. 139.

${ }^{267}$ Ob. cit., p. 57.
} 
na observação do mundo fático ${ }^{268}$, pode-se arriscar a afirmação segundo a qual parece que estamos diante do domínio do chamado Direito Penal do Autor. Sim, pois a impressão é que o texto legal em lume preocupa-se bem mais em prevenir personalidades com potencial criminógeno (pedófilos ou abusadores) do que em combater condutas, de fato, perigosas (a posse sem ânimo de distribuição de dito material pornográfico infantil, a rigor, não significa perigo para ninguém).

Portanto, a crítica que aparece está relacionada com a legitimidade (ou não) de uma função meramente preventivo-dissuasória dessa classe de incriminação. Afinal, como estamos diante de um tipo penal de perigo abstrato - em que o risco de ofensa é bastante remoto e indemonstrável, assentado na ideia de perigo potencial do detentor desse material -, essa penalização é, na realidade, uma perigosa antecipação de tutela penal, que pode levar a exageros e situações desproporcionais. ${ }^{269}$

Por tudo isso é que merece prevalecer a parcela da doutrina cuja leitura do referido tipo penal somente pode apontar para a necessidade de um sentido finalístico concreto de satisfação sexual do detentor aliado ao objetivo de posterior distribuição do material.

\footnotetext{
268 Ainda nos dizeres de BOLDOVA PASAMAR, o que reforça o quanto afirmado até aqui sobre a duvidosa justificação desse delito diante da repressão ao próprio "jeito de ser" do indivíduo, "en realidad, es lo más cercano a la rechazable idea de castigar el mero pensamento con que podemos encontrarnos, y ello le resta legitimidad a la intervención penal cuando no exista peligro real ni potencial que pueda demostrarse por medio de diagnósticos médicos en relación con la personalidad del concreto poseedor del material.” Ob. cit., p. 58 (destaques meus). Ou seja, além do nítido caráter "corretivo" da incriminação, atrelada ao mundo das cogitações ou presunções, o critério preventivo não pode ser demonstrado com absoluto sucesso.

${ }^{269}$ Bem por isso, ALEXANDRE ASSUÇÃO E SILVA é contrário à necessidade de criminalização do mero acesso, já que, segundo seu pensamento, se não houver finalidade de permanência do material ou divulgação, tal deve ser um fato atípico (Ob. cit., p. 456).
} 


\subsubsection{Legitimação e fundamentos da incriminação}

A busca pelos fundamentos da tipificação da posse de material infantil é necessária para verificar até que ponto tal incriminação é condizente com os critérios erigidos pelo Direito Penal em um Estado laico e indiferente a elementos de natureza ética ou moral. ${ }^{270}$

Em termos dogmáticos, aparecem diversos fundamentos para o castigo da mera posse de material pornográfico infantil (conforme já abordado anteriormente no presente trabalho), sendo dignos de nota os seguintes: $i$ ) encarar a posse como uma contribuição à atividade de produção de materiais dessa natureza; ii) considerar que a posse constitui um perigo de comissão de comportamentos futuros delitivos por parte do possuidor ou de terceiros; iii) conceber o castigo da posse como um meio de penalizar o produtor (o real autor do delito contra a dignidade sexual dos menores), quando não se conseguir provar sua intervenção na produção.

Esses argumentos, apesar de respeitáveis, são questionáveis e acabam encontrando óbices criminológicos e jurídicos quando se busca a legitimação da interferência do Direito Penal. Vejamos cada um deles separadamente.

O primeiro deles está atrelado à ideia de que o consumo desse tipo de material reforça o abuso sexual sofrido pelas crianças utilizadas naquele contexto sexual. ${ }^{271} \mathrm{Na}$ opinião de NORMA BOUYSSOU, esse fundamento não merece prosperar, pois castiga o mero consumidor pelo simples fato de possuir um objeto de criação ilícito, sem ânimo de comercialização nem difusão ante terceiras pessoas. A crítica residiria na circunstância de que

\footnotetext{
270 NORMA BOUYSSOU, Professora de Direito Penal da Faculdade de Direito da Universidade de Buenos Aires, mostra preocupação de afastar qualquer elemento moral e lança as seguintes bases sobre as quais o tema deve ser abordado: “en la posesión de la pornografía infantil, el último interrogante es ¿cúal razón la condujo a ser elevada como hecho punible? Y en relación a ese punto, considero que no basta encontrar un fundamento moral o ético según el cual el comportamiento del poseedor se considera reprochable.” BOUYSSOU, Norma. Delito de posesión - de nuevo sobre su escenario respecto a la acción. A su vez, una consideración a tenencia de pornografía infantil para uso proprio. Em: FAYET JÚNIOR, Ney; MAYA, André Machado (org.). Ciências penais: perspectivas e tendências da contemporaneidade. Curitiba: Juruá, 2011, p. 63.
}

${ }^{271}$ Aqui, está-se diante da equiparação com o delito de receptação, o que será objeto de estudo em tópico próprio. 
o detentor desse material não pode participar da lesão já consumada contra a dignidade sexual dos menores, visto que as imagens já foram produzidas no passado e apenas foram parar nas mãos do consumidor - salvo, por óbvio, se se provar que houve uma encomenda por parte do consumidor junto ao "traficante". 272

Nesse caso, diante da impossibilidade real de se imputar ao consumidor uma suposta "participação" no comportamento criminoso do produtor desse tipo de material - em razão da evidente distância temporal e espacial -, remanesceria uma eventual aplicação da teoria da imputação objetiva diante da incrementação do risco.

Mesmo assim, não haveria base para a legitimação dessa incriminação, já que a eventual responsabilidade do possuidor não estaria baseada no fato de seu comportamento poder ser arriscado para bens jurídicos, senão na alegação de que sua conduta poderia dar a um terceiro (o produtor, por exemplo) motivo para cometer um delito. E, claro, a invocação dessa circunstância para a produção do material não reúne os requisitos para que se considere o consumidor como indutor ou partícipe do fato delituoso.

A penalização de condutas relacionadas com a posse de material pornográfico infantil bem se enquadra, desde logo, naquela linha de raciocínio do Direito Penal da segurança, que desloca o foco da incriminação do dano ao perigo e, às vezes, do perigo ao perigo. Justamente aí reside o risco de deslegitimação da incriminação em foco.

As consequências desse modo de pensamento são evidentes: ao antecipar de maneira significativa a abrangência da relevância penal, acaba sendo inevitável que o tipo penal se colore de significados que exprimem inegável julgamentos de cunho moral acerca do consumidor desse tipo de material pornográfico.

Com efeito, nos dizeres de SILVIA LARIZZA, “o objeto da tutela penal desbota e perde-se nas incriminações relativas à detenção de material pedopornográfico: da punição dos fatos concretamente lesivos de bens passa-se, sub-repticiamente, à punição dos autores. Pune-

\footnotetext{
${ }^{272}$ BOUYSSOU, Norma, ob. cit., p. 65.
} 
se o 'pedófilo', combate-se o 'pedófilo'. O Estado estigmatiza a imoralidade na ausência de um nexo estreito entre o proceder imoral e o prejuízo ao desimpedido desenvolvimento do bem-estar físico e psíquico do menor." 273

A análise de PEDRO PAULO FERREIRA a respeito da natureza de perigo de alguns dos tipos penais relacionados com a sexualidade dos menores também expressa preocupação com a malversação do campo de tutela penal da dignidade sexual infanto-juvenil. A sua consequência imediata na organização interna da dogmática penal revela certa dificuldade na construção do injusto penal, havendo clara confusão entre a proteção do objeto material previsto na conduta em abstrato e o interesse jurídico merecedor de tutela pela lei penal. ${ }^{274}$

O principal exemplo dessa classe de injustos penais nos quais se antecipa demasiadamente a punição sem que haja risco efetivo de ofensa ao bem jurídico resguardado é justamente a figura penal da pornografia infantil simulada, vigente em nosso ordenamento desde 2009, prevista no já aludido artigo 241-C do ECA.

Isso porque, no âmbito do tipo objetivo do ilícito, o objeto da ação aparece como manifestação real da noção de abstração e se projeta não a partir dessa ideia, mas sobre a noção mesma do bem jurídico.

E isso leva à conclusão de que a incriminação da mera fabricação ou divulgação de simulacro de pornografia infantil lastreia-se na tentativa de se reprimir o estímulo da intenção e do ânimo daqueles que procuram tal material. Todavia, a produção do referido material não redunda, a rigor, em nenhuma margem de perigo ao bem jurídico dignidade sexual dos jovens.

\footnotetext{
${ }^{273}$ LARIZZA, Silvia, ob. cit., p. 52. Calha ressaltar que ao considerar a pornografia infantil real como figura similar ao crime de receptação (conforme se analisará), essa crítica não teria cabimento, já que os aspectos morais não estariam em jogo, tendo em vista a necessidade de efetiva proteção dos menores utilizados nas filmagens. Assim, somente nos pressupostos de pseudopornografia (ou pornografia infantil virtual) é que tais considerações têm aplicação.

${ }^{274}$ Ob. cit., p. 100-101. O mesmo autor enxerga que resulta daí um "defeito de elaboração normológica, na qual a visualização legislativa passa ao concreto sem se preocupar com a abstração indispensável à origem normativa penal, em que há a captação do bem jurídico e sua relação com a conduta a ser criminalizada.” Idem.
} 
Existe, nessa seara, um fluido aumento de potencial risco de uma futura, incerta e inexata lesão ao bem jurídico que a norma busca proteger, sem, no entanto, qualquer comprovação cabal de que ocorrerá eventual concretização dessas condutas.

Nesse ponto, convém expor a opinião de PEDRO PAULO FERREIRA, que defende a incompatibilidade desse tipo penal com os ditames de um Direito Penal do fato, visto que totalmente à mercê da reprovação moral sobre as pessoas que consomem essa classe de material. Para ele, "a tipificação figura como comportamento condenável nos limites estritos da moral e da ética social eleitas. A criminalização da pornografia infanto-juvenil simulada realizou-se por meio de um superficial juízo de censura a um comportamento moralmente danoso. O exercício legislativo de construção da norma penal, aqui, careceu de uma verticalização exaustiva a investigar em quais pontos a conduta descrita coaduna-se com a tutela do bem jurídico, a que se propõe proteger, subsistindo, por fim, um valor negativo de natureza ética e não jurídico-penal e , por isso, insuficiente à legítima criminalização."275

Com isso, põe-se em dúvida, em um nível ainda mais profundo, a própria existência de um bem jurídico protegido pelo delito de posse de material pornográfico infantil para uso pessoal, sem intenção de divulgação de alguma forma daqueles documentos.

Há uma considerável vertente doutrinária que enxerga, nesse tipo penal, uma extrapolação da máxima de proteção exclusiva de bens jurídicos, castigando-se uma tendência moral do sujeito, algo inconciliável com um direito Penal próprio de um Estado social e democrático de direito.

Nesse contexto, essa tipificação teria o poder de impedir (ou ao menos dificultara demanda de pornografia infantil ou outra parecida capaz de estimular a sua produção, além de castigar condutas reprováveis desde a mera perspectiva de uma moral sexual. No entanto, segundo seu ponto de vista, nenhuma dessas duas razões ostenta força suficiente para dotar de fundamento um tipo penal que se aproxima perigosamente aos tipos de autor, de cunho antidemocrático.

\footnotetext{
${ }^{275}$ Ob. cit., p. 101, nota 59.
} 
Trata-se, como se percebe, de uma opção político-criminal mais inquisitiva, reclamada pelos setores mais conservadores da sociedade, resumida na repressão genérica da posse de material pornográfico infantil. Por conseguinte, a mera e estrita posse fica incriminada, de modo que, em todos os casos, a necessidade de comprovação de uma preordenação ao tráfico fica descartada.

De outro lado, em países como Alemanha, Estados Unidos e Reino Unido, a doutrina e a jurisprudência não compartilham dessas cautelas interpretativas, encontrando, sem maiores dificuldades, um bem jurídico apto a legitimar a incriminação, podendo ser sintetizado em duas grandes vertentes: $i$ ) a tentativa de se coibir os riscos de futuro abuso e ii) evitar o aumento na demanda por mais imagens contendo pornografia infantil. ${ }^{276}$

O Tribunal Supremo do Canadá admitiu a constitucionalidade do tipo penal de posse de pornografia infantil, apenas introduzindo algumas exceções, tais como, a ausência de tipicidade da conduta de produzir imagens criadas (e protagonizadas) pelo acusado, sempre que não haja a prática de atos sexuais ilegais (envolvendo, v.g., tortura, violência, humilhação etc.) e que seja para seu próprio consumo. Outra situação excepcionada seria aquela na qual se produza material com imagens de crianças que já tenham alcançado a idade de consentimento sexual (no Brasil, p.ex., a partir dos catorze anos), com a sua concordância e para uso exclusivamente privado. ${ }^{277}$

Outro importante fundamento invocado pelos defensores da legitimidade do tipo de posse de pornografia infantil consiste no raciocínio pelo qual quem possui esse tipo de arquivo - pouco importando a finalidade (gratificação sexual, curiosidade, a busca do lucro ou qualquer outra) - está reforçando o sofrimento da vítima (o menor abusado na origem das

\footnotetext{
${ }^{276}$ Consoante as explicações de JOHN CARR, "this increase in looking, collecting and possession is leading to more children being abused than otherwise would have been the case, because (i) it is very likely to cause a proportion of this enlarged population of lookers, collectors and possessors to go on to abuse children (ii) it also creates a demand for new child abuse images to be produced, and in order to produce these new images more children will be recruited to be abused". (Child pornography and the internet, disponível em www.make-itsafe.net/...Child_pornography_internet_Carr2004.pdf, p. 14, acessado em 05 de outubro de 2012).

${ }^{277}$ Essa exceção veio a ser abraçada pela Decisão marco 2004/68/JAI, que estabelece a ausência de punição para casos que tais. (cf. CORTINA, José Miguel, ob. cit., p. 96).
} 
imagens), à medida que esse ofendido terá conhecimento de que suas imagens estão circulando globalmente na Internet, sem esperanças de que se possa colocar fim a essa circulação. Sob esse viés, a questão do direito à proteção à própria imagem acaba sendo fundamental para lastrear a incriminação, até mais do que a discussão sobre a ofensa (ou não) à moral sexual coletiva.

Sobre esse tópico, merece menção a abordagem a respeito da eventual necessidade de proteção, mediante a lei penal, da imagem de adultos maiores de dezoito anos que, contra a sua vontade, veem suas imagens em situação sexual divulgadas a terceiros. Afinal, em tempos de Internet - tendo em vista a facilidade de compartilhamento de arquivos digitais -, é bastante comum alguém postar ("subir") vídeos ou imagens próprias ou de outrem em momentos de intimidade. Nesse caso, calha questionar: a interferência estatal mediante sanção penal teria legitimidade? Ou apenas surgiria o direito de indenização no campo civil?

O legislador brasileiro, recentemente, diante de caso de repercussão nacional envolvendo a divulgação pública de fotos de uma famosa atriz televisiva ${ }^{278}$, entendeu por bem criminalizar a conduta em exame por meio de lei que prevê alguns delitos informáticos (Lei n. ${ }^{\circ}$ 12.737, de 30 de novembro de 2012). Pela redação legal, aquele que invade sistema informático alheio e, sem sua autorização, divulga os dados, agora responderá por ilícito penal. $^{279}$

\footnotetext{
${ }^{278}$ Trata-se da publicação, sem autorização, de cerca de trina e seis fotos em poses sensuais da atriz Carolina Dieckmann, em que ela aparecia nua e seminua,em momento de intimidade. Como ainda não havia previsão legal de impor ao autor da divulgação sanção penal, o Congresso Nacional aprovou, a toque de caixa (aliás, como costuma acontecer em casos de enorme repercussão nos meios jornalísticos), o texto legal em comento.

279 "Invasão de dispositivo informático. Art. 154-A. Invadir dispositivo informático alheio, conectado ou não à rede de computadores, mediante violação indevida de mecanismo de segurança e com o fim de obter, adulterar ou destruir dados ou informações sem autorização expressa ou tácita do titular do dispositivo ou instalar vulnerabilidades para obter vantagem ilícita:

Pena - detenção, de 3 (três) meses a 1 (um) ano, e multa.

$\S 1^{\circ} \mathrm{Na}$ mesma pena incorre quem produz, oferece, distribui, vende ou difunde dispositivo ou programa de computador com o intuito de permitir a prática da conduta definida no caput.

$\S 2^{\circ}$ Aumenta-se a pena de um sexto a um terço se da invasão resulta prejuízo econômico.

$\S 3^{\circ}$ Se da invasão resultar a obtenção de conteúdo de comunicações eletrônicas privadas, segredos comerciais ou industriais, informações sigilosas, assim definidas em lei, ou o controle remoto não autorizado do dispositivo invadido:

Pena - reclusão, de 6 (seis) meses a 2 (dois) anos, e multa, se a conduta não constitui crime mais grave.

$\S 4^{\circ} \mathrm{Na}$ hipótese do $\S 3^{\circ}$, aumenta-se a pena de um a dois terços se houver divulgação, comercialização ou transmissão a terceiro, a qualquer título, dos dados ou informações obtidos."
} 
Não obstante o intuito do legislador em buscar aumentar o grau de proteção da intimidade e privacidade do cidadão, parece-nos que o ideal seria evitar a instrumentalização do Direito Penal para esses fins, bastando que aqueles que se sintam ofendidos ou violados, em caso de divulgação, busquem a reparação do dano por meio de ações indenizatórias, suficientes, a nosso ver, à repreensão desses fatos.

Ademais, retomando o raciocínio acerca da legitimação dos delitos relacionados à pornografia infantil, em paradigmática decisão da Suprema Corte norte-americana, no caso conhecido como Osborne v Ohio, foi mantida a constitucionalidade de uma condenação por detenção de material desse tipo levando-se em conta o argumento de que, atacando-se a posse, haveria um decréscimo da demanda e, por consequência, reduzir-se-ia a oferta de pornografia infantil. $^{280}$

Estamos diante de caso típico de aplicação da lei da oferta e da procura, tendo em vista que o combate à demanda do material seria um meio - indireto, diga-se - de acabar com o oferecimento de pornografia infantil, principalmente em um mercado tão fluido e extreme de limites claros como o que rege as trocas de informações pela rede de computadores.

Também vem sendo justificada a tipificação dessa conduta com base na constatação de que, mediante a posse de material pornográfico infantil, outras crianças e adolescentes poderiam se tornar mais vulneráveis, às práticas do processo conhecido como grooming (ou seja, aliciamento de menores para fins pornográficos ou para turismo sexual ${ }^{281}$ ).

\footnotetext{
${ }^{280}$ De acordo com um recente precedente jurisprudencial da região espanhola de Vizcaya, o tipo penal em lume justifica-se em razão de interesses coletivos, plurissubsistentes, já que ele "protege a inviolabilidade, a segurança e a dignidade da infância em abstrato, adiantando-se as barreiras de proteção, buscando-se combater o perigo inerente a condutas que possam fomentar práticas pedófilas sobre menores concretos" (SAP Vizcaya, sec. $1 .^{\circ}, \mathrm{n}$. 4/2009, de 28 de janeiro, cf. CORTINA, José Miguel, ob. cit., p. 98, nota 224.

${ }^{281}$ FERNADEZ TERUELO traz interessante conceito desse tipo de comportamento: "el child grooming, online child grooming o Internet child grooming puede definirse como el conjunto de estrategias que una persona adulta desarrolla para generarse la confianza de un menor (en nuestro caso, menor de 13 años) a través de Internet con fin último de obtener concesiones de índole sexual voluntarias o forzadas (en el modelo español, alguno de los delitos de agresiones o abusos sexuales, corrupción o pornografía infantil). Se designa como acoso o aproximación sexual a menores en la Red y el término completo en el ámbito que nos ocupa sería entonces child grooming o internet grooming. La confianza (acercamiento) del menor, en la práctica, se obtiene generalmente a través de formas de empatía y/o engaños y, en menor medida, coacción o amenaza; tras esta fase amable se pasa a
} 
Ao lado dos fundamentos gerais da incriminação dessa modalidade de conduta, também merece exame mais acurado o estabelecimento dos bens ou interesses jurídicos quando se fala em posse de pornografia infantil.

\subsubsection{O bem jurídico tutelado: individual ou coletivo?}

A doutrina especializada vem destacando que, quando se fala em delitos relacionados com a pornografia infantil, podem ser identificados alguns bens jurídicos, todos eles tendo como viga mestra o direito de o menor não ser exposto ao contexto sexual precocemente - o que redundaria na ofensa à garantia de livre desenvolvimento físico e psíquico. No entanto, não é apenas a "liberdade sexual" do menor que está em questão.

Desde logo, a grande discussão que se erige sobre esse tema consiste em verificar se estamos diante de um bem jurídico de cunho individual (restrito aos adolescentes utilizados nas filmagens ou expostos a elas, por exemplo) ou então de natureza coletiva (supraindividual).

Em um primeiro momento, pode-se pensar no bem jurídico liberdade sexual dos menores como o interesse a ser abarcado pela previsão legal da posse de pornografia infantil. Para tanto, utilizando-se dos conceitos amplamente abordados em capítulo anterior, com a conduta de armazenar esse tipo de material, haveria ofensa ao livre desenvolvimento sexual daquelas crianças utilizadas nas gravações ou imagens.

Sem embargo, esse inicial entendimento sofre críticas diante da questão relativa à ausência de liberdade por parte de crianças e adolescentes, até porque o fato de a própria lei penal considerar como válido o consentimento dos menores para a prática de atos sexuais a

pretender un encuentro en persona con los fines descritos.” FERNANDEZ TERUELO, Javier Gustavo. Derecho penal e internet..., ob. cit., p. 153. 
partir dos catorze anos (na legislação brasileira), afastando-se o delito de abuso sexual (estupro), mas não havendo a mesma consideração no concernente aos delitos de pornografia infantil.

Aparece, então, outro grupo de interesses como opção do legislador, qual seja, a intangibilidade sexual entendida como a proteção ao livre desenvolvimento do menor em temas de sexualidade.

A partir dos citados bens jurídicos, e trazendo a discussão ao campo da mera posse de pornografia infantil para uso próprio, a questão que surge é saber se são condutas que realmente afetam o desenvolvimento do menor.

$\mathrm{Na}$ realidade, ao menos aparentemente, parece que os interesses apontados não se veem afetados em absoluto nas hipóteses em lume, pois a posse se produz quando o menor afetado já foi gravado e, de outro lado, a pornografia infantil virtual, como se demonstrará mais adiante, que não grava a menor algum.

Ou seja, no delito de posse de pornografia infantil para uso próprio, o comportamento tido como delituoso é posterior à efetiva lesão de bens jurídicos. Segundo a análise crítica de ALEXANDRE RAMALHO DE FARIAS, seja qual for o ponto de vista ante o tipo penal em análise, a realidade é que a conduta de possuir a pornografia infantil para uso pessoal, apesar de imoral, está distante de qualquer interesse jurídico, no tempo, no espaço ou na linha de ação do anterior 'abuso sexual'. O comportamento daquele que, sem haver participado da ação gravada, satisfaça seus impulsos sexuais visualisando-os não segue perpetuando os ataques a bens jurídicos. $^{282}$

Já na opinião BOLDOVA PASAMAR, o sentido da punição da conduta de deter material pornográfico infantil está centrado no fato de se procurar evitar ou prevenir que, no futuro, se siga instrumentalizando os menores nesse mercado negro. Para isso, inevitável verificar que a incriminação se justifica na mera existência de um perigo abstrato para os bens

\footnotetext{
${ }^{282}$ A incidência da normativa..., ob. cit., p. 184.
} 
jurídicos de conteúdo sexual de menores e incapazes. No entanto, tal proteção alarga-se para abarcar não apenas os jovens realmente afetados por aparecer no material pornográfico, "como também todo o conjunto de crianças, adolescentes e incapazes que no futuro poderão ser vítimas de tal instrumentalização sexual."283

Nesse sentido, pode-se afirmar que a criminalização da posse de pornografia infantil para uso próprio, seguindo a tendência mundial verificada em acordos e tratados internacionais, como já vimos, é dirigida a sancionar penalmente todo o circuito ou ciclo de uma política de tolerância zero ante o afastamento de menores de qualquer influência pornográfica.

Em outras palavras, como a popularmente chamada "rede de pornografia infantil" está relacionada com abusos e a exploração de menores nos mais variados níveis (lenocínio ou tráfico de pessoas, turismo sexual, prostituição infantil etc.), busca-se abranger todo o cabedal de condutas que, de alguma maneira (mais ou menos intensa), atinge a juventude nesse âmbito. A ideia é reprimir todos os elos da imensa "indústria" da pornografia infanto-juvenil.

Sem embargo das posições até aqui destacadas, no caso de posse de pornografia infantil prevalece a falta de interesse jurídico diretamente protegido e, por conseguinte, há a criação de uma tutela penal adiantada e desnecessária, que contradiz os princípios de intervenção mínima do Direito Penal e da subsidiariedade. ${ }^{284}$

Por tudo isso é que se poderia entender que nos delitos relacionados com a pornografia infantil não haveria outros bens protegidos que não uma suposta moral sexual coletiva.

$\mathrm{Na}$ análise crítica de ALEXANDRE FARIAS sobre os delitos envolvendo pornografia infantil na Espanha, "parece que o legislador mudou a defesa dos bens jurídicos próprios para

\footnotetext{
${ }^{283}$ PASAMAR, Miguel ...Pornografía infantil en la red.., p. 29 Tradução libre.

284 Cf. ALEXANDRE RAMALHO DE FARIAS, ob. cit., p. 185. Essas críticas são compartilhadas por MORILLAS FERNÁNDEZ, pois "os bens jurídicos referidos para o comum das figuras típicas compreensivas desta modalidade delituosa - liberdade e indenidade sexual, intimidade, dignidade, livre desenvolvimento da personalidade - carecem da relevância para efeitos de posse simples, no entanto já foram lesionados em virtude de condutas antecessoras na hipotética cadeia de tráfico de pornografia infantil, não podendo apreciar-se pelo mero fato de possuí-la." (ob. cit., p. 322).
} 
quiçá assumir a defesa de funções um tanto questionáveis como a proteção da infância e a diminuição ou extinção do material pornográfico infantil, buscando perseguir o 'pedófilo' não por suas condutas, senão pelo que 'é'. Neste caso, como parece claro, não se confunde com as clássicas funções de repressão e prevenção que inspiram o Direito penal, e que tampouco podem substituir-se ao bem jurídico nas tarefas relativas à lei penal". ${ }^{285}$

Assim, resulta cristalina a ausência de unanimidade, por parte da doutrina, acerca de qual seria, exatamente, o bem jurídico carecedor de tutela penal no tocante ao delito relacionado com a posse de pornografia infantil, uma vez que, tanto sob o aspecto futuro (remoto e indemonstrável risco de abuso sexual) quanto presente (a conduta de detenção, em si, sem qualquer elemento indicativo de divulgação ou propagação desse tipo peculiar de material), a legitimação dessa incriminação é bastante questionável.

Também fica insustentável, a nosso sentir, lastrear a criminalização dessa espécie de conduta sob os enfoques da proteção da infância como um todo, ou seja, com base na moral sexual coletiva, naqueles padrões médios de comportamento, que revestem qualquer tipo de ação sexual envolvendo crianças e adolescentes.

O legislador, nesse ponto, repita-se, deve sempre ter como norte os princípios de intervenção mínima e da subsidiariedade do Direito Penal, a fim de se afastar do risco de transformar as instâncias repressoras em verdadeiras patrulhas morais, condenando o mero pensamento das pessoas (por mais repugnantes que possam ser).

Sim, pois invocar o livre desenvolvimento sexual dos jovens ou o combate à indústria mundial da pornografia infantil tampouco parecem conferir legitimidade a condutas que,

\footnotetext{
${ }^{285}$ Ob. cit., p. 187. Continua o mesmo autor, demonstrando a incongruência do próprio sistema legislativo, que "esta pseudofunção do Estado em diminuir a pornografia infantil, travestida no suposto bem jurídico 'moral sexual coletiva' é mais do que duvidosa quando a iniciação sexual na Espanha se situa hoje em torno de catorze/quinze anos, sem que isso cause catástrofe alguma e siga tendo sentido proteger uma suposta intangilibidade sexual, neste e em outros preceitos, de pessoas de dezessete anos ou mais. (...) O Estado espanhol deve compatibilizar os tratados, convênios, decisões marco em que tome parte com os princípios gerais de Direito penal, próprios de um Estado Democrático de Direito - como a intervenção mínima, subsidiariedade, legalidade estrita e proteção de bens jurídico-penais,m mediante a expressa exigência de lesão ou colocação em perigo dos mesmos em cada uma das condutas que vá reprimir penalmente."
} 
sequer diretamente, atingem a dignidade sexual desse grupo de pessoas. Afinal, convenha-se, aceitar a incriminação de um comportamento apenas por causa da pressão da opinião pública em extirpar a pedofilia da realidade social, sem observar os critérios de ofensividade, da exclusiva proteção de bens jurídicos ou da esfera de autonomia individual dos cidadãos - tudo em nome de uma perigosa antecipação da tutela para atos desprovidos de dano a terceiros pode ensejar a institucionalização do famigerado Direito Penal do Autor.

Nesse quadro, com o devido respeito às posições contrárias, é digna de realce a enorme fragilidade dos pressupostos de sustentação às teses que advogam a constitucionalidade dos tipos penais relativos à posse de pornografia infantil (com ainda menos força na modalidade simulada ou virtual). Não obstante a pertinência da preocupação internacional com esse grande "Mal do século XXI" que é a propagação de material pornográfico infantil, facilitada pelas modernas tecnologias digitais, é certo que não se pode admitir a negação do Direito Penal como ultima ratio, com limites de intervenção nos direitos fundamentais do indivíduo. $^{286}$

A questão que se coloca, desde logo, no tocante aos delitos relacionados com a pornografia infantil, reside na completa incerteza quanto à própria eficácia das leis penais que buscam atingir a figura do mero consumidor desse material, cuja postura, a rigor, nada tem a ver com o efetivo abuso sexual infanto-juvenil, perpetrado por terceiros, em um marco temporal impreciso.

Veja-se que o escopo do presente trabalho em momento algum recai sobre a discussão a respeito dos comportamentos ligados à ideia de "tráfico" de pornografia infantil. Nestas hipóteses, resulta clara a existência de irrefutáveis e inquestionáveis interesses a serem tutelados pelo ordenamento jurídico, inclusive por meio da sanção penal.

\footnotetext{
${ }^{286}$ Tendo em vista essa linha de pensamento, ALEXANDRE RAMALHO DE FARIAS, quanto à submissão do ordenamento penal espanhol às diretrizes internacionais de se erigir a posse à categoria de crime, assevera que "a atuação do Direito penal democrático em um Estado de direito frente à pornografia infantil impõe de lege lata uma interpretação que atualize a função de carta magna do Direito Penal e sua 'natureza fragmentária' e que alcance conceitualmente somente o âmbito de punibilidade que seja indispensável de proteção do bem jurídico e de lege ferenda a adoção pelo legislador dos recortes facultados pelo regulador europeu, especialmente a supressão do delito de posse de pornografia infantil para uso próprio e do delito de pseudopornografia ou pornografia simulada." (ob. cit., p. 188).
} 
Em outras palavras, a enorme dificuldade em apontar, sem dúvidas, o real bem jurídico protegido pelo tipo penal de posse surge como indicativo do terreno nebuloso onde situadas as recentes reformas legislativas que redundaram na criação dessas figuras delituosas na esmagadora maioria dos países de tradição liberal.

Portanto, ante a insuficiência dos critérios até aqui enumerados pela corrente dos defensores da legitimidade do crime de posse de pornografia infantil "real" - mais insuficientes ainda na chamada pseudopornografia, em que não há sequer algum menor envolvido, como se observará mais à frente -, resta-nos checar se haveria sentido de tal tipificação sob outro enfoque, ou seja, no exame post factum das consequências decorrentes do consumo sobre os menores efetivamente utilizados de forma ilícita.

Afastada a legitimidade dos fundamentos comumente levantados - diante da fluidez dos critérios genéricos de perigo abstrato, desvinculados da tutela exclusiva de bens jurídicos - cumpre, agora, saber se, em uma abordagem sistemática mais aprofundada, haveria motivo para justificar a intervenção penal em razão de uma ofensa reflexa (ou indireta) aos menores expostos nas filmagens.

Nesse particular, deixam-se de lado os argumentos genéricos de cunho moralizante, mais voltados à sexualidade infanto-juvenil, para voltar a atenção ao questionamento se ao cosumir pornografia infantil o agente não estaria reforçando, chancelando, o abuso cometido no fato originário ao material. E mais, apesar do reconhecimento desse reforço, imprescindível observar se tal proceder deve ser considerado crime, passível de uma pena privativa de liberdade.

Ou seja, deve haver o deslocamento do enfoque temporal dado aos tipos penais em comento, voltando o olhar ao dano já realizado (quando da utilização das crianças e adolescentes), e deixando de lado os eventuais (e não-comprovados) efeitos futuros (a possibilidade de abuso ou exploração sexual). Assim, questiona-se: é possível legitimar o tipo em comento pela eventual equiparação, por exemplo, com o delito de receptação? Pode-se 
falar em igualdade de situações apta a sustentar a conformidade desse tipo penal de posse com um Direito Penal garantista? As respostas a essas indagações serão tratadas no próximo tópico.

\subsubsection{Pornografia infantil e "receptação"}

A mudança de enfoque com relação à posse de pornografia infantil leva a uma linha adicional de justificação para essa incriminação, voltada a evitar a proliferação de arquivos que tais: ao interpretar o tipo penal em questão como eventual delito de dano ou de perigo concreto - e não de perigo abstrato -, essa linha de raciocínio compara aquele injusto com uma figura típica bastante conhecida dos ordenamentos jurídicos, a receptação.

Aqui, então, já aparece como fundamento dessa classe de injusto uma vertente importante: elevar a mera posse à categoria de crime faria sentido, tendo em vista o comportamento estruturalmente semelhante ao da receptação (crime patrimonial), em que é atacado - ainda que de modo reflexo ou mediato - o mesmo bem jurídico ofendido pelo delinquente originário, cujo delito é estimulado ou favorecido.

Os comportamentos tanto do detentor de pornografia infantil quanto do receptador de mercadoria de origem espúria, sob esse anglo de vista, seriam semelhantes, equivalentes e teriam como mola propulsora a atuação delitiva, no primeiro caso, daquele que produz/elabora o material e, no segundo, do indivíduo que comete o delito patrimonial (furto, roubo e estelionato, entre outros). Com isso, a semelhança entre ambas as figuras delitivas mostra-se evidente, ao menos no aspecto estrutural.

Assim, antes mesmo de traçar as linhas comparativas entre ambas as espécies delituosas a fim de verificar a existência de legitimidade dos diferentes tipos penais relacionados com material pornográfico infantil (real, virtual e técnica), mostra-se necessário um breve histórico sobre as características informadoras da receptação. 
Em primeiro plano, convém destacar a origem do crime de receptação, que remonta ao Direito Romano. De acordo com texto de JOSE SOARES DE MELO, apresentado originalmente como tese de cátedra na Faculdade de Direito da Universidade de São Paulo e que foi publicado como livro em 1937, "a palavra receptação provem do direito romano. Há um texto especial do Digesto consagrado aos receptadores - De receptatoribus: Dig. L. XLVII, Título XVI. Paulo, nas suas Sentenças, parágrafo $4^{\circ}$, título III, Livro IV, refere-se a receptores. Os receptatores do Digesto, os receptores de Paulo, eram os receptadores de malfeitores. (...) Para a receptação de coisas a legislação romana não possuía thermo technico especial. (..) A Republica não conheceu a receptação, pessoal ou real, nem firmou doutrina sobre a matéria. (...) Só no Imperio passa a acção dos receptatores a ser um crimem extraordinarium, comprehendendo primeiramente a receptação pessoal, e a seguir a real, isto é, receptação propriamente dita."287

E já adiantando uma posição que prevaleceu por bastante tempo, o autor destaca a inegável ligação entre a receptação e o crime originário: “o receptador, tanto o de pessoas como o de coisas, era punido com penas severisssimas. Mais de uma lei lhes comminava as mesmas penas do delicto principal. Esse direito equiparava o receptador ao delicto de onde provinham as coisas receptadas. (...) No antigo direito italiano são numerosas as disposições sobre a receptação, tanto pessoal como real, punida com penas particulares, ou com a mesma pena do delicto principal". ${ }^{288}$

Ainda acerca das características da receptação, importante fazer menção mais detalhada sobre a subordinação desse crime ao delito previamente cometido. Seguindo o raciocínio de JOSÉ SOARES DE MELO, “receber, comprar, guardar, ocultar, vender ou aceitar em penhor, ou troca, coisas obtidas por meio de um delicto, eis o elemento material da receptação. É consequentemente de mister a existencia de um 'delicto anterior', que os criminalistas ora denominam 'facto principal', ora 'delicto de fundo, 'delicto originario', 'delicto antecedente'. Desde os tempos antigos, em que a receptação e o favorecimento se

\footnotetext{
${ }^{287}$ MELO, Jose Soares de. Receptação. São Paulo: Revista dos Tribunais, 1937, p. 6-7.

${ }^{288}$ MELO, Jose Soares de. Ob. cit., p. 12. Cabe ressaltar que os romanos, nesse particular, tinham um conjunto de regras um pouco confuso, no qual se confundiam as figuras da receptação real (de coisas) e pessoal (que depois veio a ser considerado outro delito autônomo, o favorecimento pessoal, previsto no atual artigo 349 do $\mathrm{CP}$ brasileiro). Para os fins do presente trabalho, apenas a primeira modalidade terá utilidade.
} 
confundiam, subordinados à figura de um só delicto, até os praxistas italianos, (...) grande é a confusão que têm emmaranhado juristas e legisladores. Aliás, o problema se presta a divergencias: se o delicto anterior é causa, a receptação não passa de efeito, e ambos de ligam por intima connexão. Todavia, se um não segue o outro, necessariamente, se os elementos de ambos são diversos, nítida será a sua linha demarcatoria."289

Nesse quadro, o autor traz as seguintes ponderações sobre o critério de cumplicidade estabelecido entre os autores dos distintos delitos - critério esse que durante certo período foi o mais aceito pela doutrina ${ }^{290}$-, já que "para os práticos italianos, e ainda numa ou noutra lei vigente, a receptação é acto de cumplicidade, porque suppõe necessariamente a existencia dum facto principal punivel. Não passa de concurso post delictum. Segue o delito anterior; prolonga-o nas suas consequencias. Completa-o. Não possue caracter independente. Não pode, pois, ocupar logar á parte num estatuto penal, devendo estar incorporada a outras determinações legaes". ${ }^{291}$

Com o passar do tempo, a despeito de ter aparecido timidamente nos idos de Carsóvio, foi a partir do Século XIX que tomou corpo a ideia segundo a qual a receptação deveria ser encarada como uma espécie independente, autônoma, individualizada de delito. De fato, com a mudança de enfoque, a receptação, além de passar a abranger delitos antecedentes de qualquer

\footnotetext{
${ }^{289}$ Ob. cit., p. 115.

${ }^{290}$ Em obra mais recente dedicada aos crimes patrimoniais, ROMEU DE ALMEIDA SALLES JUNIOR faz um breve resumo do entendimento doutrinário acerca dessa relação de necessária concatenação entre a receptação e o delito anterior, destacando que "na Idade Média, a receptação era punida como forma de cumplicidade. O receptador era considerado cúmplice. A sua conduta era equiparada a uma nova contreactio, relacionando-se, portanto, ao crime de furto. Aponta a doutrina que, no direito moderno, dois sistemas se apresentam: 1) O sistema tradicional, que continua a ver na receptação uma forma de cumplicidade. Tal sistema é acolhido pela legislação francesa, abrangendo o favorecimento pessoal e o recebimento de coisas, O receptador recebe a reprimenda na condição de cúmplice. 2) O segundo sistema passou a considerar a receptação como um delito autônomo. Sua punição é distinta da punição do crime anterior. Os antecedentes históricos dessa orientação econtram-se em Carpsóvio (1635), que defendia a punição mais branda ao autor da receptação. Encontramos referências a esse sistema, no direito positivo, na Constituição Teresiana, da Áustria, de 1768, e na Josefina, codificação de José II, de 1787 (H.C. Fragoso, Lições, cit., p. 548-9)." (Furto, roubo e receptação: indagações, doutrina, jurisprudência, prática. São Paulo: Saraiva, 1995, p. 275). Aqui já é possível observar a mudança de paradigma entre a "tradicional" posição de considerá-lo um crime indissociável com o antecedente e a "moderna", que o toma por crime autônomo. Como se verá, este último é o entendimento dominante nas legislações europeias e na brasileira.

${ }^{291}$ Ob. cit., p. 115-116. No mesmo sentido, NELSON HUNGRIA, em seu "Comentários ao Código Penal", trouxe a seguinte linha de raciocínio que prevalecia à época: "Para o tratamento penal, o receptador era equiparado ao latro ou fur (...), considerada a receptação como auxilium post delictum ou cumplicidade subsequente". Ob. cit., p. 301.
} 
natureza (e não apenas patrimonial stricto sensu), entendeu-se que ela não poderia ser tida como uma mera forma de cumplicidade em relação ao delito anterior, excetuadas as hipóteses em que tenha havido conluio prévio entre o autor do crime anterior e o receptador. ${ }^{292}$

Realmente, é entendimento assente o de que não há falar em co-autoria ou mesmo participação após o momento consumativo do delito, parecendo mais adequado mencionar a natureza acessória da receptação. Com isso, ou o indivíduo se liga à conduta de outro, respondendo com este pelo mesmo crime (co-autoria), ou, após o cometimento de dado delito - que tenha gerado uma anormal situação patrimonial -, atua buscando proveito próprio ou alheio, de natureza econômica, cometendo um delito distinto, vinculado ao primeiro, caracterizado como receptação. ${ }^{293}$

De fato, alertava JOSÉ SOARES DE MELO, ainda na primeira metade do Século passado, que "a maioria dos autores pleiteia posição sui generis para a receptação, afirmando que é autonoma, mas depende da outra infracção. Não lhes interessa, em rigor, o delicto antecedente, senão a coisa obtida por meio criminoso, e que passa a ser alvo da nova acção. (...) Qualquer que seja a theoria, jamais se poderá fazer abstracção do crime anterior. Legalmente, a receptação tem de depender de outro delicto.,"294

Bem por isso, cumpre transcrever a posição da doutrina pela qual, com o desenvolvimento do estudo da figura penal em questão, considera-o autônomo, no sentido de merecer previsão específica na lei penal. Isso porque, trazendo-se o exame da matéria sob o ângulo da ordem jurídica atual, a receptação apresenta-se sempre vinculada a um delito anterior, porém, tal circunstância não lhe retira o caráter de crime autônomo ${ }^{295}$. Tal

\footnotetext{
${ }^{292}$ HUNGRIA, Nelson. "Comentários...”, ob. cit., p. 301.

${ }^{293}$ SALLES JÚNIOR, Romeu de Almeida. Ob. cit., p. 284.

${ }^{294}$ Ob. cit., p. 116.

${ }^{295}$ HUNGRIA resume assim a relação entre os crimes, utilizando a expressão para caracterizar esse tipo penal: "a receptação pode ser definida como crime que acarreta a manutenção, consolidação ou perpetuidade de uma situação patrimonial anormal, decorrente de um crime anterior praticado por outrem. É um crime parasitário de outro crime." Ob. cit., p. 302-303, destaque nosso. Na mesma linha, CARRARA faz uso de um termo que se adequa perfeitamente à noção acima transcrita, ao referir-se aos agentes como continuadores do delito anterior (cf. destacado por JOSÉ SOARES DE MELO, ob. cit., p. 168). Daí é possível observar o caráter de perpetuação da ofensa patrimonial sofrida pela vítima do fato ilícito antecedente.
} 
independência pode ser verificada em razão de a receptação prever uma sanção própria, ao mesmo tempo em que se desvincula da punição do crime anterior. ${ }^{296}$

Outra importante característica a ser destacada do crime de receptação - e que será de extrema valia quando analisarmos a posse de pornografia infantil simulada (ou virtual) - é aquela atinente à necessária existência de um crime anterior como pressuposto de configuração da receptação.

Muito embora o viés autônomo da receptação leve à conclusão de que o fato será punível "ainda quando desconhecido ou isento de pena o autor do crime de que proveio a coisa" (artigo 180, parágrafo $2^{\circ}$, do CP), a imprescindibilidade de ter havido um ato ilícito prévio afastaria a incidência da receptação naqueles casos em que o comportamento anterior não é tido como delituoso pela lei penal. Assim, por exemplo, na hipótese de ocorrência de contravenção penal ou mesmo um irrelevante penal (como no caso de montagem de material pornográfico sem o envolvimento de menores reais), aquele que adquire, oculta ou armazena tais bens não pode, em tese, responder pelo delito do artigo 180 do $\mathrm{CP}^{297}$

Prosseguindo no exame, convém observar as diferentes razões dadas pela doutrina para o injusto de receptação: $i$ ) a manutenção da situação patrimonial contrária ao direito, gerada por um fato delituoso anterior (teoria da perpetuação); ii) tirar proveito da coisa obtida mediante um delito; iii) o auxílio, ainda que indireto, ao autor do fato prévio; $i v$ ) a frustração da restituição da $r e s ; v$ ) a manutenção da situação patrimonial gerada pelo delito anterior junto a um perigo abstrato de que se cometam novos crimes contra o patrimônio no futuro; vi) a manutenção da situação gerada pelo delito e a lesão a interesses gerais na segurança jurídica, pois o receptador oferece um motivo para a comissão de ilícitos penais patrimoniais no futuro. $^{298}$

\footnotetext{
${ }^{296}$ SALLES JÚNIOR, Romeu de Almeida. Ob. cit., p. 277.

${ }^{297}$ Esse ponto será retomado em detalhes mais adiante.

${ }^{298}$ BOUYSSOU, norma. Ob. cit., p. 68.
} 
Feito esse breve exame teórico-dogmático da fundamentação do crime patrimonial, cabe aferir a possibilidade de aplicação análoga quanto ao tipo penal de mera posse de material infantil, em seus variados aspectos.

$\mathrm{Na}$ análise de GIMBERNAT ORDEIG, ao adquirir, armazenar ou possuir material pornográfico infantil, o agente acaba reforçando, chancelando, o dano causado originariamente aos menores utilizados naquelas filmagens ou imagens, decorrendo daí a legitimação do injusto. O agente, nessa hipótese, estaria atacando, de maneira indireta ou reflexa (mediata), o mesmo bem jurídico violado quando da exploração ou do abuso dos menores representados no material.

Segundo a visão do autor, cada vez que o adquirente de pornografia infantil carrega o vídeo das imagens reproduzidas, há a perpetuação do ataque à dignidade e à liberdade das crianças que foram gravadas anteriormente e, de outro lado, contribui para a manutenção e a expansão de uma nova e degradante indústria que tem como objetivo e pressuposto a comissão de delitos gravíssimos contra a infância. ${ }^{299}$

A Suprema Corte norte-americana, por exemplo, no caso Osbourne v. Ohio, teve a oportunidade de reconhecer a constitucionalidade de uma condenação por detenção de material pornográfico infantil sob o argumento equiparado à popularmente conhecida lei da oferta e da procura. Conforme essa linha, erigindo-se a mera posse à categoria de ilícito penal, haveria um natural decréscimo da demanda, o que levaria à consequente diminuição da oferta desse material.

O fundamento da referida decisão judicial tem como justificativa o fato de que, cada vez que essas mesmas imagens pornográficas contendo menores são utilizadas, volta-se a abusar daquelas pessoas, de modo que o consumidor seria uma espécie de "abusador por

\footnotetext{
${ }^{299}$ GIMBERNAT ORDEIG, Enrique. La Reforma de Los Delitos Sexuales. Em: Prólogo a la quinta edición del Código Penal Espanhol. Barcelona: Tecnos, 1999, p. 18.
} 
representação", pois ele não desfrutaria do material se alguém não tivesse abusado anteriormente em seu lugar. ${ }^{300}$ Daí a equiparação com a receptação.

Além do abuso indireto, há preocupação quanto ao aumento da demanda, residindo aí o outro aspecto de comparação entre as figuras delituosas. Afinal, "ao adquirir o material pornográfico, o agente pratica um crime semelhante à receptação, apesar de não participar diretamente do crime (estupro ou roubo), aproveitando-se de seu produto (fotos e vídeos ou mercadorias roubadas). Deste modo, sua conduta afeta indiretamente o bem jurídico protegido, porque aumenta a demanda em relação ao material pornográfico infantil”. 301

A partir do momento em que se enxerga o consumidor dessa categoria de material como o elo final da complexa cadeia da pornografia infantil ${ }^{302}$, a circunstância de alguém adquirir, possuir ou armazenar dito material, em termos causais, tem como consequência o estímulo indireto da violação ou do abuso de menores. Ao apreciar, buscar ou visualizar pornografia infantil, com o objeto de satisfazer a sua lascívia, a conduta do possuidor do referido material consubstancia-se no reforço às ilegalidades já cometidas contra os menores utilizados nas imagens.

Afinal, como a punição da receptação é aceita e está incorporada ao ordenamento jurídico brasileiro (e da esmagadora maioria dos países com a mesma cultura jurídica) há tanto tempo sem que tenha tido sua legitimidade contestada pela doutrina ou jurisprudência, "a aquisição de pornografia infantil também pode ser penalizada, como forma de desestimular a produção, a venda ou a divulgação desse material". 303

\footnotetext{
300 "Cada vez que ocorre a veiculação de imagens contendo crianças em ambiente sexualizado, de certa maneira, há novo abuso do menor ali retratado. Por essa razão, em parte, algumas pessoas preocupam-se sobre o foco da investigação de pessoas que consomem esse material porque eles podem tornar-se abusadores em potencial." CORTINA, Jose Miguel, ob. cit., p. 97, nota 221.

${ }^{301}$ GARCIA DA SILVA, Camila. Pornografia simples e qualificada. Revista de Ciências Penais, ano 9, $\mathrm{n}^{\circ} 16$, 2012 , p. 252.

${ }^{302}$ Como já mencionado, cadeia essa que engloba desde o produtor, o elaborador, o explorador comercial (nos casos em que haja o ânimo de lucro), aqueles que contracenam com os menores, passando pelos distribuidores e propagadores do material, até chegar na figura do consumidor final.

303 ASSUNÇÃO e SILVA, Alexandre. Violações a princípios constitucionais e penais na legislação de combate à pornografia infantil. Revista dos Tribunais, vol. 890, p. 454. São Paulo: RT, 2009.
} 
Assim, no tocante à modalidade de aquisição de material pornográfico infantil real, não há dúvida da pertinência da comparação com o delito de receptação, uma vez que, mesmo tratando-se de crime autônomo, é inegável o caráter de "continuador" ostentado pelo indivíduo que obtém tais imagens ou vídeos Há, dessa forma, a prorrogação da violação causada a crianças e jovens no momento anterior.

De outro lado, quando se fala em mera posse ou armazenamento de pornografia infantil, ainda que real, há quem entenda que a equiparação entre tal conduta com o delito de receptação não se sustenta. Sim, pois de acordo com ALEXANDRE ASSUNÇÃO E SILVA, "possuir ou armazenar não significa por si só estímulo à prática do crime de produzir ou divulgar pornografia infantil, pois não requerem necessariamente contato com quem produziu o material pornográfico. De fato, pela Internet é possível ter acesso a tais materiais e armazená-los no computador de maneira autônoma, sem que seja preciso adquiri-lo onerosa ou gratuitamente. Um indivíduo pode ter encontrar imagens de pornografia infantil (...) sem necessidade de contato/comunicação com os responsáveis pelo sítio. Sabe-se que o dono de site que contenha pornografia infantil tem conhecimento do número de acessos a ele. Pode-se argumentar, então, que quem acessa um site e depois copia fotos ou as imprime estimula seus donos a mantê-lo ativo. Porém, as condutas de 'adquirir' (...) e 'acessar' são diferentes, tanto que o legislador só incriminou a primeira (...)".304

Dessa maneira, segundo o autor, não teria aplicação o argumento de que a posse corresponderia à ocultação prevista como modalidade de receptação (artigo 180 do CP), pois se cuidam de condutas distintas. No caso da ocultação de produto oriundo de ilícito penal, o escopo é evitar que o objeto permaneça distante do real proprietário, ao passo que na posse (ou armazenamento) de pornografia infantil, isso não se dá, visto que a obtenção de imagens constantes de um site não impediria nem dificultaria o encontro da fonte do material. ${ }^{305}$

\footnotetext{
${ }^{304}$ Ob. cit., p. 454-455. Como se vê, aqui o autor traz à tona a questão referente ao mero acesso de imagens constantes de algum site, assunto já abordado anteriormente; só que o faz sob outro aspecto, qual seja, o afastamento da comparação da mera posse de pornografia infantil com o delito de receptação.

${ }^{305}$ Ob. cit., p. 455.
} 
Diante disso, ainda consoante a posição do autor, se o objetivo da lei é o de desestimular a divulgação, bastaria incriminar o comportamento de quem publica ou põe à disposição na rede. Com isso, seria possível que o agente possua ou guarde tal material, sem que tenha feito contato com os autores do crime antecedente, "o que retira a natureza de espécie de crime de receptação de tal conduta". 306

Esse entendimento, a despeito de inovador - e, ao que parece, isolado - e de ter trazido uma visão diferenciada do assunto, parece-nos insuficiente para afastar a equivalência com a receptação. Com efeito, não obstante a ausência de contato direto com o produtor e ainda que a obtenção tenha se dado sem a colaboração com quem o produziu ou divulgou, é fato incontroverso que, com a utilização e o manuseio de imagens com crianças reais em contexto sexual e sua posterior publicação em sítios especializados na rede de computadores, o ato de copiar, imprimir ou guardar tal material acaba perpetuando o anterior dano ao bem jurídico tutelado.

Além disso, também acaba sendo mais complexa a tarefa de enfrentar o argumento pelo qual a posse e o armazenamento estimulam os provedores e donos de sites a mantê-los disponíveis na rede mundial de computadores, fomentando o anterior abuso a crianças e adolescentes. Isso sem falar que estão presentes os demais pressupostos já abordados acerca do delito de receptação, revelando-se frágeis os contra-argumentos do autor. Portanto, cremos que tal posição mostra-se um passo além do aceitável, em termos exegéticos e levando em conta aos critérios de política criminal aplicados ao caso.

De qualquer modo, é possível concordar com o mesmo autor, quando ele advoga a tese de que o agente que guarda material pornográfico infantil de modo a permitir seu compartilhamento via Internet com terceiros, não se cuida de mera posse ou armazenamento,

\footnotetext{
${ }^{306}$ Idem, ibidem. No texto, é feita a seguinte descrição, a título de ilustração: "a situação é semelhante à de alguém que encontra fotos pornográficas de menores na rua, sem saber de onde vieram. Se apenas olhar as fotos e deixá-las onde estavam, não terá praticado crime. Porém, se resolver guardá-las consigo, terá praticado o crime do art. 241-B. Mas nem na primeira conduta nem na última, pode-se dizer que houve um ato que estimulou a prática do crime de produzir material pornográfico, pois não houve o liame subjetivo entre quem produziu ou divulgou o material pornográfico e quem o guardou."
} 
mas de ato equivalente à publicação, fazendo incidir o preceito do art. 241-A do ECA, sendo legítima a sua incriminação.

Por sua vez, ao trazer o quanto até aqui levantado às hipóteses de aquisição, posse ou armazenamento de pseudopornografia infantil (sem o envolvimento de crianças reais, previsto no artigo 241-C do ECA e que será objeto de análise em tópico adiante), nota-se incabível a comparação com o delito de receptação.

Isso por uma simples razão: conforme destacado, o crime de receptação pressupõe a anterior prática de um fato criminoso e, muito embora a mera "simulação" de menores em imagens e vídeos esteja presente na lei penal brasileira, parece-nos que tal comportamento não se reveste de relevância penal, caindo por terra a necessária existência de uma "origem espúria" daquele objeto.

Ora, se é lícito afirmar que cabe a cada ser humano escolher os caminhos a seguir no campo moral, não devendo as leis sancionar quaisquer comportamentos, ainda que não sigam os padrões sociais, sem que lesionem direitos de terceiros ou constituam um perigo concreto de lesão, o que não se dá com a simples posse de material infantil virtual, a sustentação da legitimidade desse tipo por analogia à figura da receptação caba por se desmoronar.

Em hipótese alguma cabe equiparar objeto de valor patrimonial (bens móveis ou imóveis) decorrente de ilícito (furto e roubo, por exemplo) com uma montagem irreal de meras representações gráficas com aparência de crianças ou adolescentes. A comparação é claramente descabida, de modo que, quando se tratar de aquisição de pornografia simulada, o fato nem de longe pode encontrar legitimação análoga à da receptação, como ocorre nas outras modalidades de pornografia real.

Ante o exposto, em resumo, a comparação da posse de pornografia infanto-juvenil com o tipo penal da receptação mostra-se válida desde que haja a efetiva aquisição de material contendo pornografia real, ou então o descarregamento dessas imagens, tendo em vista a perpetuação das ofensas irrogadas contra as vítimas do delito originário. De outra banda, a 
conduta de possuir ou armazenar, apesar da dúvida suscitada pela doutrina, justifica-se pelo inegável caráter de estímulo da manutenção, por exemplo, de sítios cujo conteúdo envolva pornografia ilícita. Já a posse de pseudopornografia infantil não se enquadra na comparação com os pressupostos da receptação, em razão da ausência de fato criminoso anterior.

\subsubsection{Consumo de material pornográfico infantil: estímulo ou arrefecimento à violência sexual efetiva (Tese da Instigação ou Tese da catarse)?}

Desde que o consumo de material pornográfico infantil ocupou a agenda política dos Estados, principalmente no mundo ocidental após a década de 1990, com o advento das facilidades de troca de dados propiciada pela rede mundial de computadores, uma das grandes questões que permeiam o debate da criminalização da mera posse desse material pode ser resumida nos seguintes questionamentos: o acesso e a visualização de representações audiovisuais de crianças e adolescentes em contexto libidinoso servem para estimular os consumidores a colocar em prática seus desejos sexuais? Ou, ao contrário, o efeito do contato com essas imagens seria exatamente o de arrefecer tais instintos (tese da catarse)?

Estabelecer a eventual relação causal entre o consumo de pornografia infantil e o abuso sexual infanto-juvenil é fundamental, na exata medida em que, diante da dificuldade de se apontar a efetiva afronta ao bem jurídico tutelado (dignidade sexual dos menores utilizados em filmagens), o argumento geralmente invocado para legitimar tal incriminação está trelado com a ideia de que consumidores desse material se afigurariam como "estupradores em potencial".

Para tanto, de início, é preciso identificar o perfil desses consumidores, bem como os interesses que impulsionam essas pessoas a desejarem manter contato com pornografia infantil, mesmo com o fim de apurar até que ponto a justificação do injusto penal se sustentaria. 
Os estudiosos do tema traçaram uma lista com as categorias dos usuários de pornografia infantil na internet, que pode ser assim resumida: i) usuários lúdicos, que são aqueles que visitam páginas de pornografia infantil apenas por mera curiosidade ou como uma forma de entretenimento breve; ii) usuários em situação de risco, que são aqueles que acabaram desenvolvendo um interesse pela pornografia infantil, porém não o fariam não fossem as facilidades proporcionadas pela rede de computadores, iii) usuários compulsivos sexuais, formado pelo grupo de pessoas que possuem interesse específico em crianças ou adolescentes como verdadeiros objetos sexuais e, por isso, buscam esse tipo de material na internet. $^{307}$

As motivações apresentadas por esses possuidores de pornografia infantil dão lugar a outro tipo de classificação, podendo ser condensadas em quatro grupos distintos: i) interessados sexualmente em crianças impúberes (pedófilos) ou em adolescentes (hebéfilos), que se utilizam da pornografia para saciar suas fantasias sexuais; ii) usuários de pornografia sem limites, que são pessoas que estão permanentemente procurando novos e diferentes estímulos sexuais; iii) indivíduos com curiosidade sexual, que apenas baixam algumas poucas imagens para satisfazer sua inquietação e $i v$ ) pessoas interessadas em obter lucro (vantagem econômica) por meio da venda e distribuição dessas imagens e vídeos ou então do estabelecimento de sites que requerem uma contribuição financeira para se fazer o download do conteúdo pornográfico infantil.

Como se vê, variados são os motivos que podem levar alguém a buscar pornografia infantil na internet, cabendo aos operadores do Direito, caso a caso, verificarem a presença do elemento subjetivo para se subsumir (ou não) o consumo desse tipo de material com a figura delituosa da posse prevista nos respectivos ordenamentos jurídicos dos países.

A importância de se relacionar o perfil do consumidor, e as circunstâncias por detrás de tão inusitada conduta de buscar pornografia infantil, reside no esclarecimento das variadas facetas da figura do possuidor do aludido material, para se aferir de que maneira o interesse do

\footnotetext{
${ }^{307}$ WORTLEY e SMALLBONE, ob. cit., p. 21.
} 
bem-estar e do direito ao livre desenvolvimento sexual infanto-juvenil estaria sendo afetado com essa modalidade de comportamento.

A grande informação extraída de ambas as classificações atina com a noção de que não existe uma figura única, estanque, rígida de consumidor de pornografia infantil, como à primeira vista o senso comum pode sugerir. A questão é mais complexa e multifacetada do que se imagina.

Assim, por exemplo, será que a pessoa que tem contato com representações pornográficas de crianças e adolescentes apenas por mera "curiosidade" deve sofrer o rigor da repressão e punição penal? ${ }^{308}$ E aquele usuário da internet apreciador de pornografia em geral, cujo interesse seria somente o de alargar seu catálogo do objeto admirado? A incidência da lei penal faria sentido nesses casos?

Uma das tentativas de responder a esses questionamentos é voltarmos o olhar quanto ao aduzido no início do presente tópico, ou seja, quais são as consequências práticas do consumo de pornografia infantil para se verificar o acerto (ou o desacerto) dos fundamentos invocados para amparar os tipos penais relacionados ao tema.

Comecemos com os defensores da denominada tese da instigação, segundo a qual a verificação do aumento do consumo - por meio de acessos, downloads etc. de arquivos de imagem ou audiovisuais ${ }^{309}$ - serviria de impulso estimulante para o agente passar da fantasia á concretização do abuso sexual.

A reconhecida instituição "Save the Children", cujo objeto de atuação repousa na proteção da infância e da juventude em seus mais variados aspectos (culturais, educacionais,

\footnotetext{
${ }^{308}$ A bem da verdade, por mais se que possa julgar estranha, inusual ou excêntrica esse tipo de "curiosidade", ou mesmo que se constate um péssimo gosto ou um hábito "estranho" esse de buscar tão repugnante classe de pornografia, a questão ainda é pertinente para fins de configuração do injusto penal. Ou então para se checar a efetiva imprescindibilidade de incriminação desse tipo de conduta.

${ }^{309}$ Por óbvio que o consumo de pornografia infantil não se resume apenas aos arquivos eletrônicos, por meio da $w e b$, já que ainda remanescem, imagina-se, algumas representações em material físico, de papel. No entanto, pelo cediço predomínio, nos dias atuais, das tecnologias digitais, bem como diante da dificuldade em se investigar os dados empíricos de pornografia infantil "tradicional", preferiu-se cingir o exame ao universo online.
} 
de saúde, o combate à exploração econômica e sexual dos menores etc.), defende ponto de vista consonante com o espírito das reformas legislativas na esmagadora maioria dos países que tipificaram a posse para uso dessa classe de material, qual seja, a legítima antecipação da tutela penal (perigo abstrato) como meio preventivo e dissuasório de futuras agressões sexuais contra crianças e adolescentes.

Para essa organização, a pornografia infantil pode diminuir as inibições do delinquente e permite ao infrator minimizar e distorcer condutas abusivas. Segundo essa óptica, as investigações levadas a cabo demonstram que o uso de pornografia infantil para alguns delinquentes opera como um mecanismo que lhes possibilita transpor os freios inibitórios, contradizendo a desacreditada "hipótese catártica", que será objeto de análise mais adiante. ${ }^{310}$

Sob esse ponto de vista, quando é alcançado um nível superior de interesse, a maioria dos viciados em pornografia infantil apresenta desejo de manter contato direito e real com menores. Nessa esteira, o consumo de imagens acaba sendo insuficiente, de modo que a pretensão de manter relações sexuais com menores aparece como o próximo e natural passo na escalada criminosa. Esse perfil de usuário da rede de computadores utiliza os avançados meios de comunicação (chats, webcams, sistemas de mensagem instantânea etc.) para estabelecer um contato inicial com menores, desenvolver uma amizade e ao final chegar ao efetivo contato sexual.

A 1. ${ }^{\mathrm{a}}$ Turma do Tribunal Regional Federal da 3. ${ }^{\mathrm{a}}$ Região, ao denegar ordem de habeas corpus que buscava a concessão de liberdade provisória a um acusado de infringir os artigos 241-A e 241-B do ECA, abraçou a tese da instigação ao presumir - sem apoio em circunstâncias do caso concreto - o risco de efetivo abuso sexual no futuro, conforme se lê expressamente na ementa do julgado:

"HABEAS CORPUS. PRETENDIDA LIBERDADE PROVISÓRIA. PRISÃO PREVENTIVA. PACIENTE ACUSADO DE CONDUTAS PREVISTAS NOS ARTIGOS 241-A E 241-B DA LEI No

\footnotetext{
${ }^{310}$ CORTINA,..., ob. cit., p. 282.
} 
8.069/90, COMETIDAS POR MEIO DA INTERNET. NECESSIDADE DA MANUTENÇÃO DA PRISÃO. ORDEM DENEGADA. 1. Habeas Corpus objetivando a concessão de liberdade provisória a homem preso em flagrante pela prática, em tese, dos crimes capitulado nos artigos 241-A e 241-B da Lei $\mathrm{n}^{\mathrm{o}}$ 8.069/90, via internet. (...) 3. A Polícia Federal, mediante autorização judicial, utilizou a identificação de um usuário brasileiro para ter acesso à comunidade virtual GIGATRIBE e, neste contexto, colheu provas de que o paciente, em tese, praticava os delitos. 4. Dentre as chamadas parafilias encontram-se manifestações sexualmente compulsivas como fetichismo, transvestismo fetichista, exibicionismo, voyeurismo, necrofilia e a pedofilia. Os portadores dessas situações revelam padrão de comportamento caracterizado pela repetição como um quadro compulsivo. Essa compulsão acaba por trazer enorme dificuldade no controle da sua própria expressão significando um fator de maior propensão a condutas criminosas que podem vitimar pessoas que são a base das "fantasias" que permeiam a respectiva parafilia. 5. Sucede que mesmo os comportamentos que podem anteceder as condutas violentas do portador dessa parafilia como a excitação diante de simples imagens de práticas sexuais envolvendo pessoas pré-puberes - são repudiados em todo o mundo dito civilizado, e entre nós constituem-se em infrações penais graves. Nessa tipificação enxerga-se a presença do Direito Penal 'preventivo' - a exemplo do que antigamente se fazia na capitulação das chamadas 'contravenções penais' cujo objetivo era prevenir comportamentos danosos evolutivos para o 'mal maior' que visa reprimir atos que possam consubstanciar manifestações da parafilia denominada de pedofilia, transtorno que pode evoluir para a situação muito mais séria de abuso sexual infantil. 6. Necessidade de manutenção da prisão, até porque o paciente (estudante de pedagogia) trabalha numa ONG que cuida de crianças carentes; é certo que com essa singularidade profissional o paciente poderia com facilidade, em progressão criminosa, 'evoluir' da mera excitação sexual diante de imagens, à efetiva prática de libidinagem com indivíduos pré-puberes. 7. Ordem denegada." (TRF-3, 1. ${ }^{\mathrm{a}}$ Turma, HC n. ${ }^{\circ}$ 
0037603-73.2009.4.03.000, rel. Johonsom di Salvo, v. u., j. 04.05.2010, Dje 14.05.2010 - destaques nossos).

A posição daquela Corte, sem qualquer cerimônia, em um desfile de ilações, manteve a prisão cautelar com base na previsão apriorística de que o acusado poderia "evoluir" do campo imaginário à prática de efetivo abuso. Para tanto, admitiu lançar mão do "Direito Penal preventivo" para lastrear o risco à ordem pública, trazendo à colação, mesmo que de forma latente, a tese de que a mera excitação decorrente da exposição pode levar à necessária progressão criminosa. ${ }^{311}$

Prosseguindo na análise, para muitos, a pressão familiar e social, a consciência da comissão de um delito mais grave e as dificuldades para levar a cabo suas fantasias acabam funcionando como impeditivos, fazendo com que essas pessoas evitem o ingresso em situações nas quais se poderia produzir o contato pessoal direto. Também têm influência na tomada de decisão de passar da fantasia à ação fatores psicológicos ligados ao autocontrole, o nível de satisfação com a atividade sexual cotidiana, no âmbito conjugal - basta lembrar que há expressivo número de pedófilos casados ou com parceira(o) adulta(o) -, bem como a empatia para com o sofrimento da vítima tida como vulnerável. ${ }^{312}$

A conversão do possuidor de material pornográfico (que seja também pedófilo) em abusador sexual acaba sendo facilitada pelos contatos entre pedófilos na internet, contatos esses que acabam gerando a chancela de seu comportamento sabidamente proibido e também o surgimento de uma consciência de grupo. Esse reforço de suas condutas manifesta-se em web pages de forma escancarada na defesa ao "direito à pedofilia" e pode levar os pedófilos a darem o salto para a prática de crimes sexuais, sendo, no mais das vezes, o turismo sexual infantil o primeiro passo nesse sentido. ${ }^{313}$

\footnotetext{
311 A nosso ver, a decisão judicial em comento pode ser objeto de severas críticas, tomando um dado nãodemonstrado (a suposta exteriorização das fantasias do acusado) como verdade absoluta para negar-lhe um eventual direito processual. Trata-se de uma solução preconceituosa e vazia de conteúdo. Era imperioso que a Corte apontasse o elemento concreto a amparar tal "periculosidade" do agente.

${ }^{312}$ Conforme se verá em tópico mais adiante, no qual se faz referência a reportagem jornalística sobre o perfil dessas pessoas.

${ }^{313}$ Segundo a compreensão de CARR, ainda que não se tenha chegado à demonstração da cadeia causal, é possível contar com testemunhos de pedófilos que reconhecem que, quanto maior a exposição ao material
} 
De outra banda, em sentido oposto, aponta o raciocínio desenvolvido pelos defensores da aplicação da "tese da catarse" à questão posta em discussão, concluindo-se, de modo polêmico, para um viés até positivo do consumo de pornografia infantil para arrefecer os ânimos de quem ostenta um intenso desejo sexual por crianças e adolescentes.

A tese catártica refere-se à natureza positiva exercida por esse tipo de material como freio aos impulsos delitivos do portador de pedofilia, isto é, a maior parte dessas pessoas unicamente possuem ou trocam pornografia infantil, porém deixam de praticar qualquer tipo de agressão sexual a menores. Por isso, não é de estranhar que alguns autores, como QUAYLE e TAYLOR sublinham a função preventiva da simples posse de material pornográfico infantil sobre a eventual realização de condutas delitivas envolvendo violência sexual. ${ }^{314}$

Segundo esse entendimento, a maior parte dos pedófilos lança mão do uso desse material com o único objetivo de alcançar um estado de excitação sexual próprio, sem descambar para o exercício de suas fantasias no mundo real. $\mathrm{Na}$ maior parte dos casos, apontam os defensores da tese catártica, após a visualização das imagens e vídeos por meio da internet, os pedófilos imediatamente desligam o computador ou então acessam outra página de conteúdo não-sexual.

E mais, os próprios usuários deste tipo de material consideram o consumo como uma terapia mediante a qual podem satisfazer suas fantasias sexuais, controlar seus impulsos e servir de freio ante a possível comissão de atos ilícitos com menores reais. ${ }^{315}$

pornográfico infantil, maior a probabilidade de colocar as fantasias em prática, citando, inclusive estudos que dão amparo às suas conclusões (CARR, John. The internet dimension of sexual violence against children: protecting children from sexual violence. A comprehensive approach". Publishing Editions. Concil of Europe. November, 2010, p. 17, apud CORTINA, Miguel Angel, ob. cit., p. 284). O autor faz referência a dois estudos, um do FBI, a Polícia de elite norte-americana ("Self-reported contact sexual offenses by participants in the Federal Bureau of Prison's Sex Offender treatment Program: implications for the Internet Sex Offenders Hernandez, novembro de 2000) e outro intitulado "From Fantasy to Reality. The link beetween viewing child pornography and molesting children".

${ }_{314}$ CORTINA, Miguel Ángel. Ob. cit., p. 282, nota 56.

${ }^{315}$ MORILLAS FERNANDEZ, ob. cit., p. 199. 
A atipicidade do tipo penal da posse de material pornográfico infantil, mesmo envolvendo menores reais, seria uma das consequências a se adotar essa posição acerca da problemática em discussão. Seria lícito falar, aqui, na teoria do menor custo (uma espécie de redução de danos) invocada por GUISADO MORENO para argumentar no sentido de que a posse desse tipo de material pornográfico suporia um freio no ciclo sexual de pedófilos, pois ao satisfazerem, por essa via, suas necessidades sexuais, evitar-se-á ou se reduzirá a prática de condutas de maior gravidade para menores e incapazes, como abusos e agressões sexuais." 316

MORILLAS FERNÁNDEZ também critica o tipo penal de posse de material pornográfico infantil, sob os argumentos de que "proibir a posse de semelhante iconografia não representa uma solução ao problema, pois a atração física segue e o pedófilo continuará consumindo material pornográfico infantil, tudo isso sem contar ademais o freio às inibições sexuais que leva a citada tendência e que, em um percentual bastante elevado de casos, evita a comissão de ilícitos mais graves".317

De toda forma, cabe ressaltar que os estudos a respeito da relação entre consumo de pornografia infantil e violência sexual não apontam para a confirmação de necessário suporte empírico a abalizar a inferência do caráter estimulante de tal material.

A propósito, convém mencionar uma pesquisa suíça pela qual, após detida análise da ficha criminal de pessoas flagradas com pornografia infantil em seus computadores, observouse o comportamento deles e chegou-se à conclusão de que uma parcela ínfima do grupo estudado (cerca de apenas um por cento) também tinha tido envolvimento com efetivo abuso sexual infanto-juvenil com contato físico, no período de até seis anos subsequentes. ${ }^{318}$

\footnotetext{
${ }^{316}$ GUISADO MORENO, Ángela. El consumo de pornografía infantil en internet. El lado oscuro de la red. Revista de Contactación Eletrónica n. $^{\circ}$ 81, 2007, p. 45.

${ }^{317}$ MORILLAS FERNÁNDEZ, David Lorenzo, ob. cit., p. 323 (cf. livre tradução). A propósito, o aludido autor chega até mesmo a questionar a utilidade prática do dispositivo ao asseverar que "através da criação deste tipo penal pode afirma-se que a taxa de criminalidade em matéria de elaboração de material pornográfico infantil diminuirá? Em razão das crescentes estatísticas na matéria, parece correta a resposta negativa".

${ }^{318}$ Segundo noticiado, "uma equipe de pesquisadores do Serviço Psiquiátrico-Psicológico (PPD, na sigla em alemão) do estado de Zurique analisou os casos de 231 homens flagrados em 2002 pela polícia e acusados de terem visto ou baixado pornografia infantil na internet. Os pesquisadores, liderados pelo psiquiatra e psicólogo forense Frank Urbaniok, queriam saber se esses consumidores de pornografia infantil tenderam a cometer crimes sexuais com contato físico, como exploração ou abuso sexual. Eles analisaram a evolução das fichas criminais desses homens desde antes de 2002 a 2008. Resultado: entre as pessoas analisadas no estudo, apenas 1\% eram
} 
O resultado, portanto, desmistifica a alegação comum de que haveria uma tendência por parte dos consumidores de pornografia infantil de consumarem os seus desejos no mundo real. De fato, a conclusão dos autores do referido estudo são as seguintes: "o consumo de pornografia infantil, por si só, na presente amostra parece não representar um fator de risco para cometer delitos sexuais com contato físico - pelo menos não em se tratando dos indivíduos sem prévias condenações por delitos sexuais com contato físico." Mais adiante, os pesquisadores aduzem que "o estudo mostra que consumidores de pornografia infantil não podem ser confundidos com pedófilos que abusam de crianças, como ocorre frequentemente na opinião pública e na mídia. Trata-se de grupo específico de criminosos". 319

A despeito das evidentes limitações do estudo (grupo de amostra relativamente pequeno, insuficiência de critérios e dados mais seguros, silêncio de muitas vítimas, em razão das relações de parentesco com os agressores), a pesquisa pode servir de base para uma mudança na forma de encarar o assunto, afastando-se os argumentos inflexíveis de que a pornografia infantil, por si só, levaria a abusos sexuais.

A título de exemplo sobre o aspecto positivo da posse de material infantil como instrumento de refrear eventuais desejos de exteriorização de atos de violência ou abuso sexuais contra crianças e adolescentes, vale observar um caso examinado pelo Tribunal Constitucional Espanhol em que um pai confessou que tirou fotos nuas de sua filha para aplacar suas fantasias e evitar chegar às vias de fato, situação esta, convenha-se, muito mais reprovável e grave no que toca com os interesses do menor tutelados por referida norma.

conhecidas por terem cometido um crime sexual com contato físico antes de 2002 , e apenas $1 \%$ cometeu tal crime nos seis anos subsequentes". (disponível em http://www.swissinfo.ch/por/top_news/Consumo_de pornografia_infantil_e_violencia_sexual.html?cid=7516398, acesso em 09 de outubro de 2012. Muito embora os dados possam ser contestados, já que não se leva em conta a chamada "cifra negra" da criminalidade sexual - de modo que nem todos aqueles que efetuaram abuso foram descobertos ou detidos formalmente -, fato é que os resultados surpreenderam e puderam fazer com que o debate sobre a questão não seja tão apaixonado ou permeado por dogmas incontestáveis no sentido de estabelecer uma relação absoluta entre as situações

${ }^{319} \mathrm{Na}$ visão de Frank Urbaniok, um dos idealizadores do estudo, se assistir à pornografia infantil tivesse um efeito de peso, o resultado teria sido bem diferente. Segundo ele, se as taxas médias de reincidência de condenados por crimes sexuais são de 10 a $12 \%$ e chegam a superar os $50 \%$ em determinados grupos de criminosos. 
Segundo a interessante sentença, após rechaçar o entendimento já esposado da nãoconfiguração, em termos objetivos, do delito de posse quando há mera nudez infantil conforme já tratado no início do presente capítulo, faz-se uma valoração das declarações do agente para confirmar a condenação: "as declarações constantes do interrogatório judicial são significativas para verificar que o acusado tinha consciência da ilicitude do material apreendido, uma vez que o relatório da autoridade que colheu o interrogatório do réu aponta, de forma verossímil, que o acusado afirmou que havia realizado as fotos e o vídeo para 'saciar sua necessidade sexual e, portanto, não produzir dano para sua própria filha. ${ }^{320}$

Conforme se verifica, o argumento pelo qual o contato com pornografia infantil teria um absoluto caráter estimulante, a ponto de servir de incentivo à prática de delitos sexuais mais graves, não se sustenta após uma análise mais aprofundada da realidade fática.

\subsection{Pseudopornografia infantil ou pornografia infantil virtual}

\subsubsection{Contextualização: a sociedade da informação, os cybercrimes e a pornografia infantil}

O nível atual de avanço tecnológico advindo do desenvolvimento de técnicas da Tecnologia da Informação e Comunicação (TIC) acabou trazendo, a par de todos os inegáveis aspectos positivos (facilitação dos contatos interpessoais, agilidade na realização de operações financeiras e comerciais, rompimento de barreiras culturais ou físicas etc.), alguns efeitos colaterais indesejados.

De antemão, o primeiro aspecto que chama a atenção quando se fala em internet repousa no seu caráter "livre", de certa forma até incontrolável, tendo em vista a ausência quase que completa de fiscalização do conteúdo do fluxo de dados e informações. Muito

\footnotetext{
${ }^{320}$ SAP Álava, sec. 2. ${ }^{a}$, n. ${ }^{\text {o } 367 / 2008, ~ d e ~} 2$ de dezembro, cf. CORTINA, José Miguel, ob. cit., p. 41 (destaque nosso).
} 
embora os governos, nos últimos anos, venham tentando impor certos limites ao que trafega no denominado mundo virtual, fato é que o conceito de rede pode designar-se como uma anomia jurídica. $^{321}$

Isso porque simplesmente não existe um estatuto jurídico internacional sobre a internet. A rede desenvolveu-se e consolidou-se como uma nova via de informação de massas sob a lógica da liberdade de informação, ou do livre fluxo de dados. ${ }^{322}$ Neste sentido, o intervencionismo estatal é contemplado como valor que poderia colocar a internet em perigo: por isso que a nova sociedade da informação possui tantas bandeiras anti-estatais e se regula por soluções cifradas dos operadores de rede, sempre à margem de regulações jurídicas heterônomas impostas pelos Estados ou por organismos, convenções ou tratados internacionais. $^{323}$

\footnotetext{
${ }^{321}$ A propósito, temos notícia de que, muito em breve, o Congresso Nacional brasileiro, diante da urgente necessidade de regulamentar a rede mundial de computadores nos aspectos jurídicos civis e criminais, votará um Projeto de Lei, de autoria do Deputado Federal Alessandro Molon (PT-RJ), denominado "Marco Civil da Internet", uma espécie de "Constituição da Internet". Segundo consta, apesar de não haver previsão de alteração dos tipos penais ora analisados (pornografia infantil), fato é que tal iniciativa configura um importante passo na definição de responsabilidades e fixação de regras pré-delimitadas para reger as complexas relações no chamado mundo virtual. Aliás, de acordo com reportagem recém-publicada, o Projeto de Lei 2126/11 ainda está aguardando votação pela Comissão Especial da Câmara dos Deputados, já tendo sido adiada tal deliberação por seis vezes, ficando a definição da matéria apenas para 2013 (cf. matéria disponível em http://g1.globo.com/politica/noticia/2012/12/votacao-do-marco-civil-da-internet-e-adiada-pela-sexta-vez-na-

camara.html, acessada em 18 de dezembro de 2012). Consoante o relator do Projeto, "a principal resistência a seu substitutivo, apresentado em julho, diz respeito à garantia da chamada neutralidade de rede. Os votos em separado, ao que tudo indica, retirariam justamente essa garantia. Esse princípio, contido no marco civil, estabelece que todo pacote de dados que trafega na internet deverá ser tratado de maneira isonômica, sem discriminação quanto ao conteúdo, origem, destino, terminal ou aplicativo." (cf. reportagem disponível em http://edemocracia.camara.gov.br/web/marco-civil-da-internet/noticias, acessado em 23 de outubro de 2012). Trata-se, como se vê, de uma tentativa de regulamentação de uma área pautada pela indefinição de regras jurídicas claras, tudo a evitar a insegurança verificável no contexto atual. No entanto, é preciso ter cautela para não se tomar medidas restritivas demais por parte do Estado, já que é justamente essa liberdade o traço característico e democrático da web.

${ }^{322}$ MORÓN LERMA, em interessante trecho no qual enaltece o caráter anárquico da rede, pontua: "Internet no tiene presidente, director ejecutivo o mandatario. No existe la figura de una autoridad máxima como un todo. En realidad, nadie gobierna internet, no existe una entidad que diga la última palabra. No está bajo el control de ninguna empresa y, de hecho, son los propios usuarios quienes asumen la responsabilidad de su funcionamiento. Cada red integrante de Internet tiene sus propias reglas". (MORÓN LERMA, E. Internet y Derecho Penal: Hacking y otras conductas ilícitas en la Red. Pamplona: Aranzaldi, 1999, p. 96)

${ }^{323}$ MORALES PRATS, Fermín. La intervención penal en la red: la represión penal del tráfico de pornografía infantil - estudio particular. Em: ZUÑIGA RODRIGUEZ, Laura; MÉNDEZ RODRÍGUEZ, Cristina; DIEGO DÍAZ-SANTOS, María Rosario (coords.). Derecho penal, sociedad y nuevas tecnologías. Madri: Colex, 2001, p. 130-133.
} 
Além da própria utilização das redes virtuais como instrumento de difusão de material infantil - o que facilita também a prática ou o estímulo de crimes sexuais contra crianças e jovens, cf. abordado acima -, os avanços tecnológicos fizeram surgir preocupações voltadas a outros aspectos da pornografia infantil, antes ignorados pelo sistema legislativo: a possibilidade de, por meio de manipulação gráfica, produzir-se pornografia infantil "virtual”, também chamada de "pseudopornografia", "pornografia técnica" ou "pornografia infantil simulada".

Todas essas modalidades de material pornográfico infantil - cada uma com suas peculiaridades e diferenças que serão objeto de análise logo a seguir - só foram possíveis de ser desenvolvidas graças às técnicas de computação gráfica. Falar sobre fotoshop ou outros programas de edição de imagens há dez ou quinze anos era algo inimaginável para o patamar tecnológico da sociedade de então.

A rapidez e o incremento das comunicações e das transmissões de dados ou informações saltam aos olhos, principalmente na primeira década do século XXI, como uma verdadeira revolução cultural e de costumes. E o reflexo disso tudo na elaboração, produção e distribuição de pornografia (e, claro, de materiais de outras naturezas) faz com que práticas criminosas relacionadas ao tema sejam aprimoradas e renovadas quase que diariamente.

A forma pela qual a sociedade e o sistema penal de países liberais do mundo ocidental vinham, há até bem pouco tempo, lidando com a pornografia infantil teve de sofrer uma drástica ruptura, diante dessa nova realidade.

E isso porque o modus operandi dos indivíduos envolvidos na chamada "indústria mundial da pornografia infantil" mudou, e muito, após a criação de instrumentos tecnológicos altamente sofisticados, relacionados com a produção de uma infinidade de representações gráficas alteradas, modificadas, editadas, enfim, "maquiadas" mediante recursos visuais nunca imaginados há algumas décadas. 
Nesse contexto fenomênico, se antes havia imensa dificuldade para a criação e divulgação de imagens de conteúdo pornográfico (seja de adultos ou menores) que não envolvessem um menor real naquele material - dadas as evidentes limitações das técnicas de impressão ou produção dessas imagens, por exemplo -, tais barreiras caíram, de forma definitiva, após o surgimento de poderosíssimos editores digitais de textos e imagens.

Atualmente, é possível retirar elementos das imagens, colocar outros, sobrepor visualizações, fazer combinações gráficas, enfim, retocar arquivos de forma a obter um semnúmero de combinações "modificadas" digitalmente representativas de pessoas ou lugares. Aliás, é possível até a criação totalmente "virtual" de pessoas em diversas situações.

Diante desse novo universo digital, aparentemente sem fronteiras ou limitações constatáveis no "mundo real", há de haver um novo paradigma aplicado às representações visuais, já que fica um pouco difícil até separar o real do virtual quando se analisa um arquivo visual ou audiovisual.

Diante desse contexto, claro que o Estado, e mais precisamente o Direito Penal (prerrogativa do uso legítimo da violência), não poderiam ficar alheios a todas essas sensíveis mudanças tecnológicas. Por isso que a maioria dos ordenamentos jurídicos resolveu introduzir, a partir da segunda metade dos anos 2000, diversas figuras delitivas relacionadas à pornografia infantil no âmbito da rede mundial de computadores. Entre elas, merece destaque a chamada pseudopornografia.

Todo o conjunto dessas drásticas mudanças tecnológicas, e que leva à incontestável relativização das fronteiras espaço-temporais, trazidas pela chamada era da informação acaba gerando, de outra parte, inéditos riscos, os quais não se verificavam no status quo ante. Até conforme já mencionado no presente trabalho, com o surgimento desses riscos, surge a necessidade de uma transição do chamado Direito Penal tradicional (com a clássica proteção de interesses individuais) para um Direito Penal "moderno", marcado pela tutela de bens jurídicos coletivos ou supra-individuais. 
Afora essa relevante modificação de enfoque, há outra tendência decorrente do chamado Direito Penal moderno, que consiste na sua incontroversa expansão, por meio de uma deliberada política de criminalização, com reflexos frequentes e parciais reformas em Códigos Penais de vários países, sempre tendo em mente, agora, a tentativa de eliminação dos tais riscos da sociedade contemporânea. Aumentam-se, consideravelmente, o marco penal dos delitos denominados clássicos, lançando-se mão da técnica dos crimes de perigo abstrato, entre outras medidas restritivas às garantias individuais do cidadão ${ }^{324}$.

O fenômeno social da chamada "sociedade do risco", no sentido de sintetizar a temibilidade pelo incerto, acaba exercendo inegável influência quando o assunto é a relação entre as novas tecnologias e a sexualidade infanto-juvenil. Aí aparece o discurso da intolerância e do medo, formatando a imagem da potencial vitimização sexual de crianças e adolescentes "como política penal a culminar na reorganização dogmática da construção do injusto penal nessa área.

Com o intuito de verificar o impacto do vertiginoso desenvolvimento tecnológico sobre a disciplina jurídica dos delitos de perigo, PEDRO PAULO DA CUNHA FERREIRA pontua que "o aspecto cíclico do espectro de perigo, mesmo que não seja reflexo de fenômenos naturais, advém de comportamentos humanos. Nesse diapasão, busca-se conciliar os (...) mecanismos de defesa contra a realidade fenomênica, sendo a tutela jurídica uma fisionomia artificial da defesa e proteção contra os riscos, em momento anterior e ulterior à sua projeção". 325

Parece que, cada vez mais, o Direito vem se utilizando dos institutos de natureza sociológica - como a questão do medo e do gerenciamento de riscos - para tentar justificar a

\footnotetext{
${ }^{324}$ Entre elas, merecem menção, à guisa de exemplo, o reconhecimento da responsabilidade penal da pessoa jurídica, a relativização de direitos e garantias processuais penais, o agravamento das condições de execução penal, a criminalização de condutas com nenhum risco (às vezes, nem mesmo indireto) a bens jurídicos e a antecipação absurda da tutela penal para disciplinar meras cogitações.

${ }^{325}$ FERREIRA, Pedro Paulo da Cunha. Um estudo acerca das relações entre a política criminal da sociedade de risco e a mídia: abordagens críticas de suas influências em face da tutela penal da dignidade sexual infantojuvenil. Revista Liberdades n. ${ }^{0} \quad 10 \quad-\quad$ mai./ago. 2012. Disponível em : http://www.ibccrim.org.br/site/revistaLiberdades/_pdf/10/artigo4.pdf
} 
tutela antecipada (e muitas vezes não-demonstrada empiricamente) no âmbito da sexualidade infanto-juvenil. Tudo em nome do combate ao desconhecido.

Nesse quadro, convém, uma vez mais, citar as palavras do crítico e professor acadêmico Jorge Coli, que, ao ser questionado se as redes sociais trazem consigo moralismo e puritanismo, opinou no sentido negativo e esclareceu que "atravessamos um período muito conservador. Mas esse conservadorismo é exacerbado exatamente pelos novos meios de comunicação, pelas redes sociais, que permitem uma intervenção maior de cada um no campo geral das opiniões e das notícias" ${ }^{326}$.

Ao invés de empreender modos de compreender o fenômeno social da precocidade juvenil no campo sexual, prefere-se enveredar pelo caminho - mais simples - da estigmatização e da proibição de qualquer conduta que possa colocar em risco o bem-estar do menor, não importando se há efetiva lesão ao interesse jurídico que se busca proteger. ${ }^{327}$

Diante disso, nada mais natural reconhecer que o campo do denominado Direito Penal sexual infanto-juvenil encontra uma sensibilidade mais intensa a essa noção político-criminal de combate ao perigo. De um lado, é inegável que a tutela desse tipo de bem jurídico está atrelada à ideia de vulnerabilidade, conforme já analisado neste trabalho, e, de outro, em razão do vertiginoso avanço tecnológico.

No "combate" à criminalidade infanto-juvenil - inclusa aí toda a problemática da justificação dogmática da incriminação de condutas relacionadas à pornografia infantil, objeto de nosso estudo no presente tópico - "o que se evidencia é o pan-penalismo tendente a erradicar não a vitimização sexual de crianças e adolescentes, e muito menos a primar pela tutela penal do bem jurídico dignidade sexual infanto-juvenil, mas sim neutralizar, a qualquer

\footnotetext{
${ }^{326}$ Cf. entrevista publicada no jornal "Folha de São Paulo", dia 23 de setembro de 2012, caderno "ilustríssima", pág. 3. Sobre a relação entre as novas tecnologias e a sexualidade, o Professor adverte que "no campo virtual, campo dos compartilhamentos virtuais, o desejo sexual tem parte imensa. A onda de conservadorismo surge como reação a essas ameaças fundamentalmente democráticas. O Facebook tem um recurso para reconhecer nudez, mas isso não impede o que há de mais subversivo nessa rede social, que é a troca direta entre pessoas".

${ }^{327} \mathrm{O}$ mesmo autor assevera que "a fobia pelo incerto ocasiona a urgência e a emergência dos sistemas formais e informais de segurança (...). O quadro de pânico, que vitimiza a sociedade ante a espera do perigo iminente, faz com que as vítimas potenciais aceitem facilmente sugestões práticas de extermínio preventivo do perigo e de sua proveniência”. FERREIRA, Pedro Paulo..., Um estudo acerca das relações..., p. 93.
} 
custo, as variantes que possam ensejar a quebra de um padrão institucionalizado de comportamento". 328

Inserida em todo esse processo expansivo relativo às tecnologias modernas, aparece a figura da assim compreendida cyber-criminalidade, cujo cabedal de incriminações se referem à modernização das antigas práticas delitivas, agora realizadas com nova roupagem (delitos informáticos). Podem ser mencionados, nessa nova realidade, algumas condutas, tais como: $i$ ) acessos não autorizados a ases de dados ou sistema informático alheios ('hacking'), com ações destrutivas ou invasivas; ii) violação de programas de computador ('softwares') para reproduzir ou copiar obras intelectuais, suprimindo direitos autorais ('cracker'), iii) a invasão à esfera da vida privada de forma indevida, mediante programas rastreadores ('sniffers'); $i v$ ) possibilidade de introdução de informações (v.g., vozes, dados, imagens etc.), violando-se a honra e a intimidade alheias ${ }^{329}$.

É claro que, entre todos os crimes informáticos, conforme dito, os alusivos à pornografia infantil possuem posição de destaque, seja por conta da relevância dos interesses jurídicos que a norma penal busca resguardar, seja pela sua cediça habitualidade.

Apresentadas essas premissas introdutórias e teóricas a respeito do tema, cabe fazer um exame mais aprofundado dos aspectos jurídicos dos tipos penais que disciplinam as hipóteses em que não haja a efetiva utilização de menores de carne e osso no contexto pornográfico.

\subsubsection{Pornografia infantil simulada: aspectos jurídicos}

A chamada pseudopornografia, em termos gerais, tem sido classificada em três tipos: $i$ ) imagens de corpos digitalmente alteradas e sexualizadas (por exemplo, a foto de uma criança

\footnotetext{
${ }^{328}$ FERREIRA, Pedro Paulo..., ob. cit., p. 94.

${ }^{329}$ Esses exemplos vêm estampados no artigo de ALEXANDRE RAMALHO DE FARIAS, A incidência..., ob. cit., p. 161.
} 
nua no banho, na qual se excluem todos os objetos, remanescendo apenas o menor, por meio de programas de computador); ii) imagens separadas em uma fotografia, como a mão de uma criança sobreposta a um órgão sexual de um adulto; iii) montagem de fotos, algumas das quais representam um menor e outras com conteúdo sexualizado.

Nesse singular tipo de material pornográfico, entende-se que a conduta de possuí-lo afeta apenas a imagem e a dignidade dos menores, e não a sua liberdade ou inviolabilidade sexuais, uma vez que não se leva a cabo nenhum comportamento - nem sequer indireto - de matiz sexual sobre as crianças e adolescentes.

Na chamada pseudopornografia infantil (também denominada morphing, no original da expressão em inglês), não se utiliza realmente algum menor ou incapaz, senão há somente o abuso de sua imagem ou voz, manipulando-as com artifícios técnicos.

Há que se estabelecer uma diferenciação entre a pseudopornografia (ou pornografia virtual) e a pornografia técnica. Na primeira, como já dito, ocorre a inserção, por qualquer meio, de imagens ou sons (voz) de menores reais - elementos estes obtidos em situações nãosexualizadas - em cenas ou imagens de conteúdo sexual ${ }^{330}$, ao passo que, na segunda modalidade, lança-se mão de técnicas de informática para "maquiar" adultos, fazendo-se passar por menores, por meio de disfarces ou simulações.

Por isso, na hipótese da pornografia simulada, a rigor, não se enquadrariam no conceito de pseudopornografia os meros desenhos animados ou quadrinhos gerados por computador, que representem menores em um contexto sexualmente explícito.

Aqui vale abrir um parêntese para tratar da questão dos desenhos animados: é bastante comum, ao realizar uma pesquisa em algum site de busca, deparar-se com arquivos que, apesar da aparência de lúdicos ou recreativos, contenham representação de sexo explícito

\footnotetext{
${ }^{330}$ FERNANDEZ TERUELO assevera que, na Espanha, "se penaliza a chamada pseudopornografia infantil ou pornografia infantil virtual (ou simulada), que consiste, precisamente, em realizar montagens com imagens (ou a voz) de menores que não intervêm realmente na conduta sexual (v.g., introduzir a foto do rosto de uma criança ou adolescente sobreposta à imagem corporal de um adulto em atividade libidinosa". Derecho penal e internet..., ob. cit., p. 124 (tradução livre do autor).
} 
utilizando personagens famosos do imaginário infanto-juvenil (por exemplo, alguma animação mostrando os famosos personagens da "Branca de Neve e os Sete Anões" ou então da "Cinderella" em um contexto libidinoso).

Caso uma criança ou adolescente encontre esse tipo de desenho animado, estará exposta aos malefícios do contato precoce com cenas representativas de sexo explícito, o que, a nosso ver, é bem mais grave do que hipóteses envolvendo outros tipos de montagem estranhas ao universo imaginário infanto-juvenil. Diante dessa situação, como proceder? É cabível enquadrar esses arquivos na noção de "pornografia infantil simulada"? É passível de incidência do referido art. 241-C do ECA?

Ora, veja-se que, a rigor, essa modalidade de material não se coaduna com a noção de simulação de pornografia infantil, uma vez que os personagens retratados, no mais das vezes, são adultos ou então criaturas fantásticas. Por isso, a mera produção de paródias erotizadas de filmes clássicos infantis, muito embora possa causar repulsa diante do extremo mau gosto que poderia descambar para o escatológico/bizarro em situações mais extremas -, não pode ser considerada crime.

A noção de pornografia infantil simulada, conforme analisado, não comporta a inclusão dessa modalidade de filme, faltando-lhe, nestas hipóteses, o critério de ofensividade que o sistema jurídico-penal busca respeitar. A nosso sentir, a despeito de eventual aumento do risco relativo ao contato indesejado de menores com esse tipo de material, ainda assim não parece que tais arquivos possam caracterizar pornografia infantil apta à incidência da norma penal.

Mesmo que haja produção e divulgação desse material na rede mundial de computadores, aqueles que portarem ou armazenarem ditos arquivos não devem sujeitar-se aos ditames do artigo 241-C do ECA, por um motivo singelo: o espírito da incriminação de condutas envolvendo pornografia infantil deve ater-se à proteção de crianças e adolescentes efetivamente utilizados nas filmagens. Adquirir ou possuir um filme ficcional contendo personagens famosos em contexto libidinoso está longe de representar qualquer ofensa a bens 
jurídicos, ficando apenas no campo do imoral (ou indesejável) segundo os ditames sociais, sendo que os pressupostos de legitimidade do delito de posse para consumo desse material (eventual reforço do dano psicológico sofrido por algum menor - critério ex post -, ou então a possibilidade de abuso futuro - tese da instigação) tampouco são configurados, já que não houve prática sexual pretérita com menor algum.

Assim, se hoje em dia existe o risco de uma criança encontrar essa classe de materiais, tal situação deve estar fora do alcance penal, sendo mais bem disciplinada por meio dos instrumentos de controle de conteúdo da Internet, seja por parte dos provedores, seja pela utilização de filtros da parte dos pais ou responsáveis pelos menores. Ou seja, não será mediante a penalização, pura e simples, desse tipo de conduta que o bem estar de crianças e adolescentes estará tutelado. A incidência de outras instâncias de controle, como a imposição de multas ou outros tipos de penalidade aos responsáveis pelos filmes, surge como medida mais eficaz para o resguardo do sadio desenvolvimento psíquico desses menores.

Ademais, nos delitos relacionados com a pornografia infantil simulada ou virtual, o bem jurídico protegido seria a dignidade sexual dos menores em geral - sendo exemplo típico de crime de perigo abstrato - além, por óbvio, da própria imagem do menor.

Acerca do abuso da imagem do menor, é importante destacar o caráter de sua inserção indevida em um âmbito alheio aos seus interesses. Aí que reside o principal fundamento para justificar a incriminação, visto que se utilizam imagens ou sons que procedem dessas pessoas para inseri-los em um contexto sexual ao qual são totalmente alheios. ${ }^{331}$

Por exemplo, ao lado da já mencionada figura da pornografia infantil "real", o ordenamento jurídico português, seguindo a tendência europeia, também resolveu penalizar todas as ações já destacadas (produzir, divulgar, distribuir, adquirir, possuir etc.) relativas a “imagens realistas de crianças não-existentes".

\footnotetext{
${ }^{331} \mathrm{Na}$ mesma direção aponta o entendimento de MORALES PRATS, para quem "cabe identificar um desvalor material da conduta relacionada com a afetação da dignidade do menor ou seu direito à própria imagem, ligado à ideia anglo-saxã de privacy, entendendo-se por esta o direito a não ser molestado ou intranquilizado na esfera privada em que o sujeito organiza de modo originário o livre desenvolvimento de sua personalidade". (ob. cit., p. 362 - tradução livre).
} 
Não obstante toda a discussão teórica e jurisprudencial a respeito da legitimidade constitucional desse tipo de conduta, em razão da duvidosa afronta à lesividade - no mais das vezes, esse tipo de comportamento não envolve interesse individual de criança alguma ${ }^{332}-, o$ legislador português decidiu erigir esse comportamento à categoria de crime.

Em primeiro lugar, é preciso destacar a dificuldade em se perceber o que está na origem dessa imposição de criminalização, visto que, a rigor, não se pode falar na proteção à liberdade sexual do menor porquanto, na hipótese específica, nem sequer menores ou outras pessoas aparentando ser menores existem.

Nesse sentido, a grande crítica que se estabelece nessa tendência criminalizadora reside no fato de se prever uma sanção penal para sustentar uma mera censura moral, sem levar em conta que o que deve ser protegido são os "menores em carne e osso, o único bem que pode justificar uma tutela penal tão ampla".333

Por outro lado, esse tipo de delito pode, de alguma maneira, colidir com o direito à liberdade de criação artística, pois pode abranger representações ilustrativas que representam uma forma de expressão.

É óbvio que existem formas artísticas consideradas chocantes pelo seu conteúdo, em face dos padrões culturais ditados pela sociedade. Porém, nem por isso tais manifestações deverão consubstanciar, per se, um ilícito penal. Exemplo mais expoente do exagero que pode representar tal criminalização seria incriminar a elaboração dos desenhos japoneses

\footnotetext{
332 Apenas para relembrar, conforme já mencionado alhures, a Suprema Corte norte-americana, no famoso caso Aschcrof v. Free Speech Coalition, declarou inconstitucional a Child Pornography Prevencion Act (1996), deixando assentado que tal previsão reduz em medida substancial a liberdade de expressão legítima, rechaçando a afirmação pela qual essa modalidade de imagem incentivariam comportamentos desviantes já que "a mera tendência de se expressar ou encorajar atos ilegais não é uma razão suficiente para proibi-la”. LOPES, José..., ob. cit., p. 156.

${ }^{333}$ Esse trecho foi extraído do artigo "Può costituire reato la detenzione di pornografia minorile?", de GIOVANNI COCO, em: Rivista Italiana di Diritto e procedura penale, Ano XLIX, Fasc. 3, jul./set. 2006, p. 874.
} 
conhecidos como hentai na noção de representação pornográfica de menores ${ }^{334}$, o que, a nosso sentir, configura abuso do poder estatal de ditar o comportamento de indivíduos que não têm o condão de afrontar o direito ao livre desenvolvimento de jovens, nem remota ou indiretamente.

Aqui vale mencionar a observação de CAMILA GARCIA DA SILVA, segundo quem “essa modalidade de pornografia [virtual] pode ser vista em mangás (quadrinhos japoneses) do estilo denominado hentai, que teve início no século XVI. Atualmente, esses quadrinhos podem retratar apenas cenas sensuais ou até mesmo sexo explícito entre meninos, meninas, homens, mulheres e criaturas fantásticas (meio humano - meio animal), tanto de orientação heterossexual quanto homossexual. Assim, esse gênero artístico pode ser visto como demonstração artística para alguns, mas também como pornográfica, dependendo do leitor e do espaço na obra tomado pelas cenas obscenas no mangá”. 335

\footnotetext{
${ }^{334}$ EDUARDO PERET, em artigo que aborda a sexualidade constante dessa tradicional e peculiar arte gráfica japonesa, destaca a necessidade de levar em conta as diferenças culturais entre a realidade brasileira e a daquele país no momento de avaliar a eventual nocividade desse material às crianças e adolescentes. De acordo com seu raciocínio, após ressaltar a presença de cenas violentas nesse tipo de HQ (dado ausente na produção brasileira, por exemplo), destaca que "outro 'problema' do ponto de vista ocidental é a 'sensualidade' - ou melhor, o que é visto como sensual. Aqui, a nudez, mesmo que parcial ou sugerida, foi por muito tempo considerada 'pornográfica' e pesadamente censurada (note-se a forte influência católica até depois do fim da Ditadura, seguida pela rápida ascensão das igrejas neopentecostais nos anos 90). A cultura japonesa encara alguns aspectos da nudez com muito mais naturalidade e tolerância, de tal modo que os adolescentes não passam por esse tipo de censura da mesma forma que aconteceu aqui. Não é que o povo japonês seja necessariamente 'mais liberal' do que nós; é que as regras culturais são outras. Além disso, no Japão, apesar da origem voltada para o público jovem, a produção de mangás e animes rapidamente se diversificou em diferentes temáticas. Ao longo do tempo surgiram inúmeros estilos e subestilos, conforme o público-alvo específico." Ao final, estatui que "essas obras não foram feitas para a nossa cultura e sim para a cultura japonesa; portanto, qualquer apropriação nossa poderá não corresponder à realidade e verossimilhança internas do produto (o que não chega a ser um ponto 'negativo', mas deve ser levado em consideração em qualquer análise). (...) tendemos a ver vários aspectos da sexualidade sob um véu de preconceito e censura, fundamentados em dogmas religiosos, algumas tradições e definições absolutas que, apesar de já terem sido ultrapassadas, ainda persistem no imaginário popular. (...) a existência de ficções literárias (fanfic) ou artísticas (fanart) de origem japonesa, contendo alguma conotação homossexual, não confirma nem justifica automaticamente a presença de tais elementos nos produtos originais. Muito do que se imagina no Brasil, sobre os produtos japoneses, fala mais sobre o imaginário e a cultura do Brasil, do que sobre as obras estrangeiras propriamente ditas". PERET, Eduardo. Percepções da sexualidade: anime e mangá. Revista ELO - Grupo de Pesquisa em Comunicação Interculturalda UERJ. 4ª Ed., Ano 1. Rio de Janeiro: Laboratório de Comunicação Integrada (LCI) do Departamento de Relações Públicas da Faculdade de Comunicação Social da UERJ, 2009. Disponível em www.elo.uerj.br/pdfs/ELO_Ed4_Artigo_animemanga.pdf. Como se vê, até diante das inegáveis peculiaridades dessa arte japonesa (e a diferença de enfoque, em relação ao caldo de cultura ocidental), a nosso ver, considerar tais representações visuais como pornografia infantil simulada é totalmente excessivo e descabido.

${ }^{335}$ Pornografia infantil..., ob. cit., p. 256.
} 
Ao recordar o caso do Second Life (situação virtual em que adultos abrem uma conta e criam avatares), a autora destaca o pensamento - ao qual o presente trabalho adere integralmente - de que "apesar desse ambiente, de certo, não ser o mais indicado para seus participantes, podendo incitar as práticas reais de pedofilia e abusos sexuais em relação à criança e ao adolescente, não cabe ao direito regular esse tipo de manifestação, porquanto não é possível vislumbrar lesão a um bem jurídico". ${ }^{336}$ De fato, a nosso sentir, representaria um indevido e exagerado alargamento da esfera penal considerar esse tipo de manifestação equivalente a pornografia infantil. Por mais espécie que cause a existência desse tipo de material, tal conduta não pode ser revestida de relevância jurídico-penal, visto que ausente qualquer critério de política criminal na mera simulação computadorizada sem a presença de menores reais.

A lei penal brasileira, mais precisamente o já apontado artigo 241-C do ECA, deixou de lado todas as críticas e, apresentando uma postura draconiana, resolveu apenar tanto o agente que simula a participação infanto-juvenil em contexto pornográfico, mediante a adulteração, modificação ou montagem de representação visual de menores, como também todos aqueles que vendam, distribuam, divulguem ou mesmo possuam/adquiram/armazenem materiais nessas condições. Ou seja, foram atingidas praticamente todas as condutas possíveis com relação à pseudopornografia, inclusive a pornografia infantil técnica. ${ }^{337}$

\footnotetext{
336 Ob. cit., p. 257. Essa posição é rechaçada por DEMÓCRITO FILHO, o qual, advogando uma interpretação mais rigorosa do tema, clamava pela modificação do ECA para incluir no conceito de pornografia infantil as tais representações não fotográficas, o que acabou sendo atendido pelo legislador brasileiro em 2008. De acordo com sua opinião, "com o desenvolvimento da tecnologia, as legislações penais dos países passaram a sofrer de um gap em relação às imagens de 'fantasia' de abuso sexual de menores. Somente uma nova ação legislativa seria capaz de afastar essa ameaça aos esforços estatais de combate à pornografia infantil, através da criação de uma subcategoria estreitamente definida de imagens ilícitas (cartoons, desenhos e imagens animadas envolvendo menores em cenas obscenas). Uma atuação legislativa é necessária para impedir a disseminação dessa nova categoria de pornografia infantil na Internet. Sem isso, fica impossível para a polícia prender ou mesmo para o Ministério Público denunciar as pessoas que possuem, produzem e divulgam esse tipo de imagens ('fantasy style')." Sem disfarçar a sanha punitiva no "combate" à pornografia infantil, afirma, citando o caso do Second Life, que "há uma compreensão generalizada entre os estudiosos de que existe uma relação direta entre o número de crimes de pedofilia e a difusão de material pornográfico infantil na Internet. As imagens divulgadas no Second Life, envolvendo reproduções animadas de sexo com crianças, servem como combustível para o abuso de crianças reais, por funcionar revigorando os sentimentos pedófilos de potenciais predadores sexuais. No mínimo, a circulação desse tipo de material serve para inculcar e desenvolver uma cultura ou sentimentos pedófilos." REINALDO FILHO, Demócrito. A pornografia infantil virtual e as dificuldades jurídicas para combatê-la - o caso do 'second life'. Revista IOB de Direito Penal e Processual Penal n 47. Jan. 2008, p. 10.

337 Sobre o conceito de pornografia infantil simulada, cabe destacar a seguinte definição dada pela doutrina nacional: "a pornografia virtual, como também denominada, consiste na criação de imagens fictícias, a partir de imagens reais de adultos em contextos eróticos que, alteradas de tal modo, mediante específica técnica
} 
E o novo texto legal ainda foi além: sem respeitar o princípio da proporcionalidade, acabou estabelecendo uma pena privativa de liberdade praticamente igual àquela prevista para a posse de pornografia infantil real (reclusão de um a três anos, no primeiro caso, e reclusão de um a quatro no segundo; ou seja, a pena mínima para as figuras é a mesma), o que denota a falta de cuidado do legislador em sopesar as diferentes situações, arranhando, assim, a própria noção de igualdade. Afinal, convenha-se, ainda que se entenda legítima a incriminação da pseudopornografia, a reprovabilidade da conduta é bem menor do que na real.

Com relação a essa nova disciplina jurídica brasileira a respeito dos delitos de posse de material pornográfico infantil - e mais especificamente a modalidade simulada -, apesar da importância do tema, é preciso salientar que a jurisprudência brasileira ainda não se debruçou de maneira profunda sobre as posições ora apresentadas - talvez diante do caráter recente da mudança legislativa.

Mesmo assim, o único precedente jurisprudencial encontrado que trata explicitamente da pseudopornografia (os demais julgados não enfrentam a questão da atipicidade da conduta) provém do Tribunal de Justiça de Minas Gerais, no qual o acusado foi condenado pelo crime do artigo 241-B do ECA em hipótese em que houve a montagem de imagem contendo um adolescente (garoto) em poses provocantes, porém ausente cena de sexo explícito. Embora a conduta tenha ocorrido antes da mudança implementada pela Lei n. $^{\circ} 11.829 / 08$, aquela Corte entendeu possível a extensão do conceito de pornografia simulada para abarcar o comportamento de quem divulga a terceiros imagens nessas condições. De acordo com a ementa do julgado:

\section{"ECA - PORNOGRAFIA INFANTIL - FOTOGRAFIA MONTADA - CONDUTA TÍPICA - ABSOLVIÇÃO - IMPROCEDÊNCIA (...). - Restando devidamente comprovado que os réus contribuíram para a divulgação, pela}

informática, aparentam ser os protagonistas das cenas verdadeiras crianças e/ou adolescentes.” FERREIRA, Pedro Paulo da Cunha; VIEIRA, Lara Maria Tortola Flores. Dos crimes relativos à simulação de pornografia infanto-juvenil: paternalismo moralista ou tutela penal da dignidade sexual de crianças e adolescentes. Em Boletim IBCCRIM. São Paulo: IBCCRIM, ano 20, n. ${ }^{\circ}$ 232, p. 11, mar. 2012. 
internet, da fotografia montada da adolescente, em cena de sexo explícito, configurado está o crime descrito no artigo 241 do Estatuto da Criança e do Adolescente.” (TJMG, 7. a Câm. Crim., Apelação n. ${ }^{o}$ 1.0629.06.028884-8/001, rel. Duarte de Paula, v.u., j. 24.03.2011, DJe 21.10.2011).

Podem ser extraídas do voto condutor do acórdão as seguintes considerações acerca da configuração do delito de divulgação de pornografia infantil por meio de montagem de foto:

“ No que tange à atipicidade da conduta, devido ao fato de que só no ano 2008 o legislador teria criminalizado a conduta de montagem de fotografia contendo cenas de sexo com a participação de criança ou adolescente, entendo que não deve prosperar, pois a conduta aqui tratada é a de divulgar fotografia, portanto uma daquelas elencadas no art. 241 do Estatuto da Criança e do Adolescente.

O fato da [sic] fotografia em discussão nos presente autos ser uma montagem em nada interfere na configuração do tipo penal descrito, uma vez que buscou o art. 241-C do Estatuto da Criança e do Adolescente foi criminalizar a conduta de manipular uma fotografia, e não de divulgar a representação visual, esta já tipificada pelo artigo 241 do supracitado Estatuto.

Ademais, não se pode esquecer que a intenção do legislador quando da criação do Estatuto da Criança e do Adolescente, era proteger a criança e o adolescente, conforme asseverado pela ilustre magistrada da causa (...) 'Não deve prosperar os argumentos de que há atipicidade da conduta eis que a foto divulgada na internet se tratava de uma montagem, não estando tal hipótese prevista no artigo 241 do ECA, uma vez que, sem dúvida a intenção do legislador, quando da feitura da norma, era proteger a criança e o adolescente, não podendo deixar de serem resguardados a honra e dignidade daquela que teve a sua exposição através da internet, ainda que através de uma fotomontagem'. 
Dessa forma, não há que se falar em atipicidade das condutas dos acusados.

Por fim, ressalto que, a despeito de a Lei 11.829/08 ter acrescentado e modificado alguns artigos do Estatuto da Criança e do Adolescente, dentre eles o art. 241, denota que tal alteração é prejudicial aos réus, não podendo alcançálos, pois os fatos ocorreram entre as datas de 30/01/04 e 31/01/04, quando a conduta de fotografar ainda era prevista no art. 241 do ECA, com a redação dada pela Lei 10.764/03, motivo pelo qual passo a reestruturar a pena imposta (...)". (destaques nossos).

Conforme se percebe, o espírito norteador do aresto ora apontado deita raízes justamente no - ao nosso sentir, equivocado - argumento da necessidade de proteção da honra e da dignidade do menor estampado na fotografia utilizada na montagem para considerar criminosa a divulgação daquela imagem, mesmo quando ainda não existia no ordenamento jurídico a figura da pornografia infantil simulada (os fatos tratados ocorreram em 2004 e a lei que introduziu o art. 241-C no ECA é de 2008).

Explica-se: o TJMG, movido pela gravidade da situação concreta e premido pelo genérico "resguardo às crianças e adolescentes", fez retroagir a norma para abarcar a simulação por meio de montagem como objeto do crime de divulgação de pornografia infantil antes da mudança legislativa. É bem verdade que o preceito legal previa, de fato, a modalidade "fotografar" adolescente como um dos núcleos do tipo voltado ao tráfico de pornografia infantil. No entanto, para fins de configuração do delito, não poderia ter havido fotografia "montada", de modo que a mencionada decisão judicial, a nosso ver, incorreu em erro ao condenar o acusado por uma conduta realmente atípica.

Assim, partindo do pressuposto de que se trata de conduta equivalente ao tráfico de pornografia infantil, a crítica a ser feita ao julgado restringe-se à equiparação, antes da modificação legal, entre fotografias "reais" e "montadas" de adolescentes como se ambas pudessem configurar pornografia infantil. Claro que o comportamento é reprovável e que de fato houve divulgação na Internet. Todavia, pelo pouco que se pode extrair do teor do acórdão, 
pareceu-nos uma postura excessivamente rigorosa, muito embora no caso concreto, pela pena paliçada, tenha sido reconhecida a extinção da punibilidade.

Por tudo isso, o Tribunal perdeu a oportunidade de, fazendo uma interpretação restritiva e condizente com os critérios informativos do Direito Penal, aplicar o princípio da legalidade e absolver o imputado, diante também da ausência de ofensividade concreta da conduta.

Os demais julgados das Cortes brasileiras que tratam do tema da pornografia infantil ainda não enfrentaram discussões mais aprofundadas sobre os aspectos dogmáticos ora tratados, nem tampouco alegações de inconstitucionalidade do tipo penal delineado no artigo 241-C do ECA. Na maioria das vezes, os Tribunais somente apreciam a necessidade de segregação cautelar dos acusados (aspecto processual), mantendo prisões preventivas por conta do resguardo à ordem pública, em casos de pornografia infantil real ${ }^{338}$, ou então mantêm condenações por tráfico e porte da mesma modalidade desse material, sempre envolvendo menores reais retratados nas imagens. ${ }^{339}$

\footnotetext{
338 Por todos, vide recente decisão do TRF da $1 .^{\text {a }}$ região assim ementada: "PRISÃO PREVENTIVA. PEDOFILIA. GARANTIA DA ORDEM PÚBLICA. HABITUALIDADE CRIMINOSA. DENEGAÇÃO DA ORDEM. 1. Havendo demonstração do envolvimento do paciente na prática reiterada do crime de pedofilia, com a transmissão de imagens de pornografia infantil via internet, é justificável supor que a sua liberdade poderá atentar contra a ordem pública, pela reiteração da prática delitiva, considerando-se que já cumpriu pena pelo mesmo delito. (...) 3. Denegação da ordem de habeas corpus" (TRF-1, 4. ${ }^{a}$ Turma, Apelação criminal n. ${ }^{\circ}$ 0050250-52.2012.4.01.0000, rel. Olindo Menezes, v. u., j. 30.10.2012, DJe16.11.2012).

${ }^{339}$ Como o objeto da discussão tratada nesse tópico diz com a pornografia infantil simulada, não se entrará em detalhes dessas decisões. De todo modo, apenas a título de exemplo, um ponto em discussão revelado pela análise jurisprudencial repousa na possibilidade (ou não) de aplicar o princípio da consunção quando as imputações de ofensa aos artigos 241-A e 241-B do ECA aparecem em conjunto. O TRF da $3^{\mathrm{a}}$ Região, invocando critério de lógica, aplicou tal princípio, deixando assentado o seguinte entendimento: "APELAÇÃO CRIMINAL. DENÚNCIA QUE IMPUTA AS CONDUTAS DE ARMAZENAR E DISPONIBILIZAR VIA INTERNET FOTOGRAFIAS E VÍDEOS CONTENDOPORNOGRAFIA INFANTO-JUVENIL. MATERIALIDADE E AUTORIA COMPROVADAS. CONDENAÇÃO PELOS CRIMES TIPIFICADOS NOS ARTIGOS 241-A E 241-B DO ECA - ESTATUTO DA CRIANÇA E DO ADOLESCENTE. APLICAÇÃO DO PRINCÍPIO DA CONSUNÇÃO. AFASTAdA A CONDENAÇÃO PELO DELITO DO ARTIGO 241-B. (...) não vejo como seja possível, do ponto de vista lógico, que uma pessoa possa divulgar uma imagem sem antes armazená-la ou possuí-la, ao menos por alguns instantes. Ainda que na mídia digital seja possível posteriormente o apagamento das imagens divulgadas, por alguns instantes o agente teria que possuir essas imagens para poder divulgá-las. No caso concreto, verifico que a prova da materialidade indica que no mesmo disco rígido (...) foram encontradas as provas tanto do armazenamento quanto da divulgação das imagens pornográficas infantis. Ou seja, no caso concreto, não há dúvida de que o mesmo meio eletrônico utilizado para a divulgação das imagens foi também utilizado para o armazenamento das imagens. Portanto, repito, não consigo imaginar a conduta do agente de praticar o crime do artigo 241-A do ECA sem antes praticar o crime do artigo 241-B da mesma lei. Em outras palavras, não consigo imaginar como o agente possa divulgar a imagem
} 
De qualquer forma, a presente análise tem como escopo contribuir para a eventual resolução de conflitos envolvendo casos de pornografia infantil no futuro, quando os Tribunais pátrios se debruçarão sobre tão peculiar tema.

De outro lado, em uma perspectiva comparada, é cabível falar que a reforma legislativa brasileira encontra eco em alguns países que também chegaram a tamanha expansão punitiva. Conforme já adiantado acima, os exemplos mais próximos de nossa cultura jurídico-penal que também incriminam a pornografia infantil virtual são a Alemanha, a Itália e a França. ${ }^{340}$

pornográfica sem antes possuí-la. Assim, aplico aqui o princípio da consunção, entendendo que o delito do artigo 241-B do ECA resta absorvido pelo crime do artigo 241-A. Acrescento a esse raciocínio que o $\S 1^{\circ}$ do 241-A do ECA tipifica a conduta do agente que armazena as imagens destinadas à divulgação. Então, parece-me que a intenção do legislador a foi de punir de maneira menos severa aquele que é o consumidor das imagens pornográficas, ou seja, aquele que recebe as imagens veiculadas por meio da internet, mas não as divulga, e apenar de forma um pouco mais grave aquele que divulga essas imagens. No caso dos autos, como restou comprovado que o réu praticou as condutas tanto do armazenamento quanto da divulgação, é cabível a condenação apenas pela divulgação, e não pelo armazenamento. Nessa linha, dou parcial provimento ao recurso do réu aqui para afastar a condenação pelo crime do artigo 241-B do ECA, em virtude do princípio da consunção" (TRF-3, 1. " Turma, Apelação criminal n. ${ }^{\circ}$ 0001348-09.2010.4.03.6103, rel. p/ acórdão Marcio Mesquita, m. v., j. 31.07.2012, DJe 01.10.2012 - destaques nossos). Em posição diametralmente oposta, o Tribunal de Justiça de Sergipe, seguindo uma linha mais rigorosa, afastou a incidência da consunção, como se vê na decisão: "APELAÇÃO CRIMINAL - (...) CRIMES TIPIFICADOS NOS ARTS. 241-A E 241-B DO ECA MATERIALIDADE E AUTORIA DELITIVAS COMPROVADAS - PRINCÍPIO DA CONSUNÇÃO INAPLICABILIDADE. (...) No tocante ao pleito de aplicação dos princípios da consunção e do ne bis in idem, sob o argumento de que o art. 241-A absorveria o art. 241-B, ambos do ECA, não merecem prosperar. No caso dos autos, não restou configurada a relação de crime-meio/crime-fim, pois o primeiro crime (art. 241-B do ECA) não foi meio para atingir o segundo (art. 241-A do mesmo estatuto). Importante transcrever trecho do Parecer da Procuradoria de Justiça neste sentido: 'Ora, não é automático concluir que o réu armazenou e possuiu as abjetas imagens de prática de pedofilia tão somente como o propósito de transmiti-las, ou divulgá-las ou trocálas, como restou comprovado, por meio de sites de relacionamento específicos para essa finalidade. Não é demasiado supor que tais imagens também serviram para que o increpado satisfizesse a própria lascívia, ou para outros fins igualmente dissociados da transmissão genérica dos arquivos. Diga-se que não se está afirmando que o ora Apelante tenha agido além das condutas prenotadas nos dispositivos estatutários mencionados; o que se assevera é a falta de prova da relação meio-fim entre tais condutas, inexistindo, pois, condão para considerar o princípio da consunção em espécie." (TJSE, Câmara Criminal, Apelação criminal n. ${ }^{\circ}$ 0523/2012, rel. Edson Ulisses de Melo, v.u., j. 18.06.2012, DJe 01.10.2012 - destaques nossos). Conforme se observa, a jurisprudência ainda não se firmou sobre a aplicabilidade (ou não) da absorção entre as figuras delituosas, cabendo aos julgamentos futuros uma definição acerca da interpretação jurídica mais acertada da situação.

${ }^{340}$ Com relação ao caso espanhol, como já apontado, a incriminação da pseudopornografia infantil limita-se às hipóteses relacionadas à traficância desse tipo de material, ou então a posse para esses fins, e desde que haja a utilização efetiva de imagens ou sons de crianças ou adolescentes no ato de montagem dos documentos. A lei espanhola excepciona os casos de pornografia técnica: "no se capta toda hipótesis de la denominada "pornografía técnica'. Quedan excluidos del perímetro típico los supuestos denominados de pseudo pornografía infantil, en la que no se utilizan a menores o incapaces, ni siquiera indirectamente en la elaboración del material, sino que se recurre a artificios informáticos o de otra índole (maquillaje, disfraz de adultos) para obtener el resultado. Asimismo, quedan también fuera del tipo los supuestos en los que las imágenes manipuladas sean las de una persona mayor de edad.” TOMILLO, Manuel Gómez. Derecho Penal Sexual Y Reforma Legal: análisis desde 
Com efeito, a lei alemã contempla a hipótese de incriminação da pornografia virtual à medida que, no $§ 184$. b.IV do StGb, pune com pena de até dois anos de prisão a conduta de quem procurar ou possuir material pornográfico que tenha por objeto o abuso sexual de crianças, sempre que tais documentos reproduzirem um fato real ou com aparência de realidade.

A disciplina legal italiana, também nos termos já expostos anteriormente, abarca os casos de busca e posse de material pornográfico infantil virtual, estabelecendo, para tanto, uma pena máxima de três anos de prisão.

Por outra banda, o Código Penal francês, em seu artigo 227-23, tipifica, em primeiro lugar, a conduta de produzir, gravar ou transmitir mensagens ou a representação de um menor para sua difusão, quando esta imagem ou representação possua caráter pornográfico. Em segundo lugar, surge a conduta de difundir uma imagem ou representação deste tipo, por qualquer meio, importá-la ou exportá-la ou fazer importar ou exportar. As penas aumentarão quando a difusão da imagem ou representação do menor, destinada a público indeterminado, se der por meio de uma rede de telecomunicações. A mera posse de ditas imagens ou representações também é punida, com pena de dois anos de prisão e multa. Tais previsões se estendem, igualmente, às imagens de uma pessoa cujo aspecto físico seja de um menor, salvo se comprovado que tal pessoa possuía dezoito anos na data da gravação de sua imagem. ${ }^{341}$

Como se vê, o alargamento da incidência do Direito Penal para alcançar comportamentos sem qualquer utilização, sequer indireta ou mediata, de menores é uma tendência sem volta, que privilegia critérios de política criminal voltados à antecipação da punição criminal em um âmbito virtual, sem ofensa à autodeterminação ou liberdade sexual infanto-juvenis. $^{342}$

una perspectiva político criminal, Revista Electrónica de Ciencia Penal y Criminología - ISSN 1695-0194 RECPC 07-04 (2005), p. 35.

${ }^{341}$ FERNANDEZ TERUELO, Javier Gustavo. Derecho penal e internet..., ob. cit. p. 112.

${ }^{342}$ Consoante as palavras de CAMILA GARCIA DA SILVA, o tipo penal em lume revela que "qualquer forma de representação visual será penalizada, criminalizando, portanto, todas as gerações de pornografia infantil, 
Por fim, há um último aspecto da pornografia infantil disciplinada pela lei brasileira digno de nota: a questão da exposição de menores à pseudopronografia. Nesse quadro, a previsão legal não contempla como fato delituoso a conduta de expor esse material (virtualmente produzido) a crianças e adolescentes.

Apesar da concordância com a ideia de que o contato da criança ou adolescente com qualquer tipo de material obsceno conter, em si, um alto caráter prejudicial aos seres em desenvolvimento, deve prevalecer a opinião esposada por CAMILA GARCIA DE SILVA no sentido de ser desnecessária "a existência de um tipo específico sobre a exposição da criança e do adolescente a essa pornografia irreal.,"343

Ante o apresentado, apesar de pequenas variações quanto às condutas tidas como ilícitas e as penas impostas, pode-se afirmar que a abordagem jurídico-penal da pseudopornografia infantil, ao que tudo indica, será ainda mais rigorosa, acompanhando o desenvolvimento das modernas tecnologias da informação e da comunicação.

\subsection{Pornografia infantil simulada e análise crítica: o tipo penal é legítimo?}

Feita essa explanação, cabe verificar até que ponto essas figuras jurídicas merecem mesmo a pecha de criminosas, ou seja, em que medida, ao criminalizá-las, o Direito Penal não está sendo instrumentalizado como panaceia de resolução de outra ordem de problemas, consistentes no abuso real de crianças e adolescentes.

inclusive aquela que toca ao estilo não fotográfico. O legislador se antecipou ao avanço da tecnologia e, por meio da expressão genérica a redação do artigo, punindo de igual modo condutas capazes de ferir a liberdade e dignidade sexual de um menor, quanto à representação por meio de desenhos e cartoons, que pode apenas ser desaconselhada pelo homem médio, mas não é capaz de atentar contra um bem jurídico." (ob. cit., p. 259 destaques meus).

${ }^{343}$ Ob. cit., p. 259. 
Mais do que isso, são cabíveis diversos questionamentos: até que medida a incriminação da posse de material pornográfico virtual é condizente com um Estado Constitucional de Direito, que não pode nem deve interferir na forma de cada um viver a sua vida e expressar sua personalidade, ainda que seja por meio de um desejo sexual por crianças e adolescentes digitalmente construídos? Será que esse tratamento não extrapola os limites ao ius puniendi? Haveria injustificada invasão à autonomia/intimidade do cidadão, erigindo-se como ilícito penal a singela cogitação ou pensamentos impuros? De que modo se pode justificar a criminalização de condutas que, nem sequer indiretamente, envolvem a efetiva interferência no direito de terceiros, já que se está diante de algo inexistente no mundo real? Não estaria a lei penal (art. 241-C do ECA) procurando aplicar os já mencionados critérios moralizantes, imiscuindo-se a moral sobre o Direito?

Não se ignora que o suposto interesse protegido pela norma seja a tutela da infância como um todo, de forma que a circulação de material pornográfico infantil seria diminuída (ou banida) com a criminalização da pseudopornografia. No entanto, não é menos verdadeiro que, no fundo, essa onda de recrudescimento parece repousar sobre questões morais, ou então, em presunção infundada de que todo aquele que consome esse material seria um estuprador em potencial, conforme já abordado.

Em primeiro plano, as sérias dúvidas que pousam sobre a efetiva existência de bem jurídico tutelado nas condutas de posse de material pornográfico infantil virtual fazem com que a legitimidade da tipificação penal nesses casos fique seriamente abalada ${ }^{344}$.

Isso porque, de acordo com a posição de ALEXANDRE ASSUNÇÃO E SILVA, a própria existência desse tipo penal fere, ao mesmo tempo, aos princípios da lesividade, da intimidade e também do devido processo legal na sua vertente substantiva (material). Nesse sentido, assevera que no caso do art. 241-C do ECA, não há lesão direta ou indireta ao bem jurídico incolumidade sexual de criançs e adolescentes. A montagem não constitui ato que

\footnotetext{
344 Não por acaso FERNÁNDEZ TERUELO pontua que "na hipótese da pornografia virtual (material pornográfico no qual, não tendo sido utilizados diretamente menores ou incapazes, são empregadas suas vozes ou imagens alteradas), o perigo para o referido bem jurídico [bem-estar da infância e juventude] ainda se mostra mais difuso, mormente diante da ausência de utilização de quaisquer menores na elaboração do material". Derecho penal e internet..., ob. cit., p. 118, tradução livre.
} 
justifique intervenção penal, uma vez que se sabe que o fato não ocorreu (não há dúvida de que é uma montagem/simulação) e que não houve a prática anterior de qualquer crime sexual". 345

Ademais, prossegue o autor, "não tem sentido punir a simulação de um ato sexual ou libidinoso com um menor. O bem jurídico incolumidade sexual de menores não é lesado com tal conduta, direta ou indiretamente. Também não constitui perigo concreto de lesão ao bem jurídico, pois não requer a prática anterior ou posterior de qualquer delito. (...) A simulação de ato sexual envolvendo criança e adolescente pode constituir ofensa à moralidade sexual, mas a moralidade não deve ser protegida pela lei penal."346

Já com relação à questão da intimidade, trazendo à baila o quanto já destacado em tópico próprio nesta monografia, diz o autor que "as fantasias sexuais dos indivíduos, desde que não concretizadas, estão protegidas pelo direito fundamental à intimidade, protegido pelo art. 5, X, da CF/1988. Criminalizar a simulação de ato sexual com menor é o mesmo que criminalizar a simulação de um estupro. Por mais imoral que isso possa ser, não há violação concreta ao bem jurídico liberdade ou incolumidade sexual." ${ }^{347}$

Ora, seja sob o ângulo dos princípios basilares do Direito Penal (lesividade, proteção exclusiva de bens jurídicos, proporcionalidade), seja diante dos critérios desautorizadores de condutas paternalistas de claro jaez moralizante, o delito de simulação de pornografia infantil fica com sua conformidade aos ditames constitucionais sobremaneira abalada.

Seguindo a tendência atual de antecipação da tutela penal, a qualquer preço, a níveis de proteção muito abstratos - o que se verifica também, em certa medida, na proliferação de crimes de perigo abstrato, como alguns delitos ambientais ou econômicos - a maneira pela qual a pornografia infantil vem sendo tratada pelos ordenamentos jurídicos, especialmente o

\footnotetext{
${ }^{345}$ Ob. cit., p. 461.

${ }^{346}$ Ob. cit., p. 463.

${ }^{347}$ Ob. cit., p. 464.
} 
brasileiro, pode representar um grave retrocesso. ${ }^{348}$ A criminalização da pseudopornografia, a nosso sentir, aparece como o ápice do desvirtuamento do Direito Penal como meio para garantir a convivência social.

Diante da ausência de ofensividade que objetivamente apresenta a atitude de mera contemplação de pornografia infantil montada, seria possível argumentar que, em um equilíbrio entre os direitos fundamentais do consumidor desse material, por um lado, e os interesses sociais da proteção da juventude, de outro, aqueles merecem primazia sobre estes. ${ }^{349}$

Em suma, enquanto a criminalização de atos de efetiva exploração - seja com fim de lucro, ou não - deve seguir a tendência mundial de recrudescimento, a nosso ver, andou mal o legislador ao criar figuras típicas que nem de longe colocam em risco o interesse ou bem jurídico que busca tutelar (a autodeterminação e o livre e sadio desenvolvimento da criança ou adolescente), como, por exemplo, a pornografia infantil simulada.

Finalmente, no tocante aos casos de pornografia infantil real, muito embora haja entendimento mais liberal - no sentido de que tais hipóteses tampouco estariam revestidas de constitucionalidade $^{350}$ - parece que a legitimidade de sua incriminação encontra guarida

\footnotetext{
${ }^{348}$ Esse é o alerta trazido por PEDRO PAULO FERREIRA e LARA MARIA VIEIRA, ob. cit., p. 19: "Seguindo o espírito da Lei 11.829, vê-se que a intenção é a tutela penal da dignidade sexual de crianças e adolescentes. Contudo, razoável perceber que em nada protege o bem jurídico o tipo do artigo 241-C, pois em nenhuma circunstância é capaz a conduta incriminada de oferecer dano efetivo ou risco iminente ao referido bem jurídico. A dignidade sexual é o estado ou situação da criança e/ou adolescente em ver-se livre de danos concretos ou potenciais prejuízos à sua intangibilidade sexual. Logo, a proteção penal do bem jurídico em epígrafe se pautaria minimamente em um resultado de perigo que lhe oferecesse riscos, o que não ocorre in casu. As simulações, nos moldes descritos pelo caput do artigo 241-C, ou mesmo a posterior divulgação do material simulado, como descreve sua forma equiparada no parágrafo único, não comportam ofensividade hábil a justificar o tipo penal em apreço." E completam os autores, advogando a despenalização dessa modalidade delitiva: "enquanto os avanços tecnológicos e seu uso não despertar no Direito de ultima ratio sua função primordial - a exclusiva proteção de bens jurídicos - quer por não conter potencialidade lesiva ou mesmo ocasionar danos efetivos -, não pode ao menos a comunidade acadêmica compartir com a punição de condutas como esta do artigo 241-C da nova Lei. (...) Por derradeiro, ante a incontestável inofensividade do tipo e da consequente descaracterização da função precípua do Direito Penal, aguarda-se, de lege ferenda, sua devida abrogação".

349 Até porque, repita-se, parafraseando ALEXANDRE ASSUNÇÃO E SILVA, "cabe a cada ser humano escolher os caminhos que escolhe [sic] seguir no campo moral, não devendo as leis sancionar quaisquer comportamentos, ainda que não sigam os padrões sociais, sem que lesionem direitos de terceiros ou constituam perigo concreto de lesão.” Ob. cit., p. 456.

350 ESQUINAS VALVERDE enumera as razões que dão guarida a essa posição: "en primer lugar, motivos de índole político-criminal, en la medida en que no se ha demostrado que su represión resulte necesaria ni eficaz a efectos de prevenir la realización por parte de los propios consumidores de abusos sexuales a menores; al igual
} 
quando comparada com o delito de receptação, visto que inegavelmente houve violação pretérita ao bem jurídico dos menores envolvidos. ${ }^{351}$

A propósito, mesmo nessas hipóteses de material pornográfico infantil real, o ideal seria estabelecer critérios mais condizentes com a gravidade concreta de cada caso. Assim, segundo os critérios de definição de criança do ECA (artigo 2..$^{\circ}$ ), é possível pensar na seguinte estrutura escalonada: $i$ ) quando os menores envolvidos nas filmagens tiverem até doze anos de idade, a posse desse material será sempre considerada ilícita e passível de punição penal ${ }^{352}$; ii) no caso de adolescentes entre doze e catorze e dezoito anos, o crime se configurará apenas se o consentimento deles for viciado; iii) se os adolescentes retratados tiverem entre catorze e dezoito anos, será crime apenas se estiverem presentes indícios de exploração sexual, prostituição ou violência real.

Essa diferenciação seria salutar diante da tentativa de conferir lógica racional ao sistema, integrando-se a necessidade de efetivo resguardo da infância/adolescência com o critério de ultima ratio do Direito Penal. Assim, de um lado, estaria protegendo de maneira absoluta o grupo mais vulnerável e merecedor da efetiva tutela penal (crianças até doze anos), ao mesmo tempo em que haveria uma flexibilização de eventual responsabilidade penal à medida que os envolvidos tivessem mais idade - e, portanto, mais discernimento a respeito do exercício da sexualidade. Com isso, evitar-se-iam situações contraditórias e geradoras de injustiça, como a configuração de pornografia infantil em hipóteses nas quais os participantes são adolescentes à beira de atingir os dezoito anos, que figuram naquele contexto sexual de

que criterios de legitimidad constitucional, teniendo en cuenta la incoherencia, al menos parcial, que dicha incriminación supondría con respecto a los citados principios de libertad de expresión y de conciencia, y al derecho fundamental a la intimidad y privacidad; asimismo, fundamentos de entidad puramente práctica, si pensamos en las dificultades derivadas de las características físicas y técnicas de Internet, que surgirán a la hora de perseguir el comportamiento del simple usuario individual que visita las páginas ilegales; o también de técnica jurídica, ya que, como se ha señalado, no cabe castigar penalmente una conducta de tenencia de material pornográfico no probada como dolosa o que no llegue a satisfacer los requisitos propios de la posesión desde el punto de vista jurídico-civil —es decir, relación material de dominio de una cierta estabilidad temporal—; y, sobre todo, razones de naturaleza dogmática, pues el comportamiento en cuestión carece de la suficiente lesividad u ofensividad en relación a los bienes jurídicos individuales que eventualmente podrían entenderse protegidos." (ob. cit., p. 225-226).

${ }^{351}$ Veja-se que, a nosso ver, a justificação fundada na ameaça de violência sexual futura não merece guarida, pelo quanto já exposto nesse trabalho.

${ }^{352}$ Muito embora, pela lei penal atual, a prática sexual com menores de catorze anos pressupõe a sua vulnerabilidade, entendemos que o melhor critério é aquele preconizado no Anteprojeto de Código Penal, segundo o qual a idade-limite cairia para doze anos de idade, acompanhando a diretriz da lei especial (ECA). 
forma consciente e voluntária, bem como no exemplo do casal de namorados adolescentes que decidem, em comum acordo, divulgar cenas de sexo por motivos exibicionistas.

A consequência direta dessa flexibilização seria a conjugação entre a proteção do bem estar de crianças e a observância da realidade social na atualidade, marcada pela liberação dos costumes e pela precocidade cada vez maior do início da vida sexual dos adolescentes.

Ainda a título de sugestão, somado a isso, poderia haver a necessidade, para configuração de pornografia infantil passível de sanção penal, da verificação de uma diferença de idade mínima (poderia ser de cinco anos, por exemplo) entre o adolescente participante da cena sexual e o adulto que com ele se relaciona. Assim, certamente se estaria garantindo que a incriminação incidisse em casos de efetivo abuso da ingenuidade ou da pureza da vítima.

Com tudo isso, a nosso sentir, haveria mais lógica e justiça no sistema, guardando-se a sanção penal àqueles pressupostos em que realmente haja a necessidade de intervenção do Estado na intimidade dos cidadãos.

Diante de todo o exposto, o escopo do presente trabalho, nesse particular, coaduna-se com a ideia de que, sob qualquer ângulo que se analise a questão, inexistem motivos suficientes para justificar a incriminação da pseudopornografia infantil, sendo de rigor, de lege ferenda, a sua extirpação do ordenamento jurídico brasileiro, revogando-se o mencionado tipo do artigo 241-C do ECA.

E no tocante à pornografia infantil real, o ideal seria considerar as circunstâncias objetivas concretas para a incidência de norma, que ficaria mais condizente com a realidade verificada no mundo atual. 


\section{CAPÍTULO 6 - PEDOFILIA E PORNOGRAFIA INFANTIL}

$\mathrm{O}$ exame jurídico-penal das figuras delituosas relativas à pornografia infantil, feito no capítulo anterior, expõe a ausência de base suficiente a amparar a constitucionalidade de condutas nas quais não haja efetiva utilização de menores em contexto libidinoso.

Se para o possuidor de pornografia infantil virtual a sanção penal não se justifica, remanesce a dúvida sobre o que fazer quando o material produzido contenha imagens ou vídeos de crianças ou pré-adolescentes efetivamente utilizados (real).

Assim, apenas para fechar o raciocínio ora exposto, cabe uma breve análise das relações entre o que se considera pedofilia e os comportamentos atinentes à pornografia infantil real; por conseguinte, neste derradeiro capítulo, busca-se examinar alguns aspectos relevantes para abordar o tema de maneira mais humana e despida de preconceitos a respeito dos indivíduos que sofrem dessa séria parafilia conhecida como "pedofilia".

\subsection{Pedofilia: breves considerações}

Como já se disse, a dissertação tem como objeto a análise crítica de tipos penais relacionados à posse de pseudopornografia infantil, cuja conclusão desaguou na necessária descriminalização, de lege ferenda, da figura delituosa, tendo em vista tal conduta situar-se na esfera inviolável do cidadão, além de ausente qualquer ofensividade relevante aos interesses dos menores.

Estabelecidas as premissas morais e jurídicas - e detectada toda a problemática a respeito de encarar os "consumidores" desse tipo de material pornográfico como meros criminosos -, é quase intuitivo perceber que, para completar o estudo, algumas linhas sobre o perfil dessas pessoas merecem destaque. 
Mais do que isso: diante da conclusão sobre o caráter patológico que acomete a esmagadora maioria desses indivíduos consumidores de material pornográfico infantil real, ainda ficariam no ar diversas e angustiantes indagações: como a praxe forense lidará com eles no dia a dia? Seriam todos, sem exceção, inimputáveis, e, por isso, passíveis de medida de segurança (artigo 26 do Código Penal)? É possível impor tratamentos compulsórios? Como solucionar esses graves problemas?

A ideia é focar o caráter efetivamente doentio da personalidade de pessoas tidas como apreciadores (ou "usuários") de material pornográfico infantil ou adolescente como base para a melhor forma de lidar com a situação.

\subsubsection{A figura do pedófilo: criminoso ou doente?}

Antes de qualquer consideração, de rigor um esclarecimento: a forma como os meios de comunicação, político e da sociedade civil em geral vêm tratando a questão da pedofilia nada tem a ver com o verdadeiro significado médico-legal, científico, psiquiátrico do termo.

Nos dias atuais, é muito comum ver e ouvir a frase "pedofilia é crime" e a ideia acaba sendo tomada, no mais das vezes, como verdade absoluta. ${ }^{353}$ Isso apenas reforça uma visão preconceituosa, maniqueísta e equivocada de encarar a figura do "pedófilo" - no mais das vezes, tido como um criminoso frio, calculista, quase que equiparado, nos tempos hodiernos, com o destinatário do "Direito Penal do Inimigo" jakobsiano. ${ }^{354}$

\footnotetext{
353 Observa-se a utilização genérica - e, neste caso, errônea - do termo 'pedofilia' também em meios oficiais como a campanha da OAB/SP contra a pedofilia (http://www.oabsp.org.br/noticias/2005/05/17/2980/), em 23 de Junho de 2011. Nesse contexto, afirmar que “pedofilia é crime, denuncie!” acaba chancelando a noção de que o indivíduo que padece de tal transtorno seria um "criminoso", ao invés de uma pessoa necessitada de ajuda/tratamento médico.

${ }^{354}$ JAKOBS, Günter, CANCIO MELIÁ, Manuel. Derecho penal del enemigo, Madri: Civitas, 2003.
} 
É preciso, pois, buscar as bases da origem etimológica do termo, e suas implicações e reflexos nos demais campos das ciências biológicas e humanas.

O significado etimológico da palavra pedofilia - aquele que gosta de crianças - é greco-latina, remontando ao século XVIII, de modo que filo, do grego, significa amigo, ao passo que o vocábulo pedo, de raiz latina, quer dizer criança, tendo sido introduzidos na linguagem científica internacional a partir do século XIX. ${ }^{355}$

Avançando no tema, a pedofilia pode ser definida como uma perversão sexual que se apresenta como predileção erótica por crianças ou adolescentes, vindo desde os atos obscenos, até a prática de manifestações de concupiscência, denotando graves comprometimentos psíquicos e morais dos seus autores. ${ }^{356}$

MANIF e ELIAS ZACHARIAS trazem uma complementação do conceito, com mais detalhes, ao conceituar pedofilia como "atração sexual de pessoas adultas por crianças. Tratase de parafilia geralmente observada entre homens, mas de cuja prática, todavia, não se excluem as mulheres. $\mathrm{O}$ objeto do erotismo mórbido podem ser crianças exclusivamente do sexo masculino ou feminino, como também, indiferentemente, de um e de outro sexo." ${ }^{357}$

A pedofilia, de acordo com o DSM-IV-TR, será diagnosticada se i) ao longo de pelo menos seis meses, o indivíduo tiver fantasias excitantes, recorrentes e intensas; impulsos sexuais ou comportamentos envolvendo atividade sexual com uma (ou mais de uma) criança pré-púbere ou no início da puberdade (geralmente com idade inferior a treze anos); ii) as fantasias, impulsos sexuais ou comportamentos causam sofrimento significativo ou danos ao

\footnotetext{
${ }^{355}$ Cf. FURLANETO NETO, Mário. Pedofilia: das bases etimológica, médico-legal e psiquiátrica aos reflexos no direito penal. Boletim IBCCrim, São Paulo, v.12, no 145. Dez. 2004, p. 6. Curioso observar que, em se levando em conta a origem etimológica do vocábulo, tanto os pais quanto os tios e avós, que sentem uma adoração a uma criança, podem ser rotulados, groso modo, como "pedófilos". Fica claro perceber que, embora essas pessoas gostem de criança, óbvio que não são criminosos, até porque tais sentimentos são nobres e naturais.

356 Cf. FRANÇA, Genival Veloso de. Medicina Legal, 5a ed., Rio de Janeiro: Guanabara Koogan, 1998, p. 491, apud FURLANETO NETO,..., p. 7.

357 ZACHARIAS, Manif e Elias, Dicionário de Medicina Legal, Ibrasa - Champagnat, 1991, apud CRUZ, Anselmo Firmo de Oliveira Pedofilia: até onde está o crime? Disponível na internet: www.ibccrim.org.br, em 29.06.2002.
} 
convívio profissional/social do indivíduo e iii) a pessoa tem, no mínimo dezesseis anos e é cinco mais velho do que o objeto de desejo.

Diante disso, cabe esclarecer a ausência de qualquer ilícito penal no comportamento daquela pessoa que, por conta de um transtorno de personalidade de natureza sexual, venha a desenvolver excitação, um estímulo sexual ao manter contato visual com crianças e adolescentes. $^{358}$

A propósito, trazendo a discussão para o campo da neurociência, convém citar a obra de DAVID EAGLEMAN, dedicada ao estudo da influência dos aspectos neurológicos no comportamento humano, verificando-se um surpreendente condicionamento de atos à própria estrutura cerebral do homem, em nível subconsciente e independente da vontade do agente. ${ }^{359}$

De acordo com o trabalho desenvolvido no livro, ao analisar o funcionamento do sistema nervoso central de determinados de problemas ocasionais relacionados com práticas condenáveis pela sociedade (como pedófilos, cleptomaníacos e jogadores compulsivos) "na interface entre a neurociência e a lei, casos envolvendo danos cerebrais brotam com uma frequência cada vez maior. À medida que desenvolvemos tecnologias melhores para sondar o cérebro, detectamos mais problemas". 360

\footnotetext{
${ }^{358}$ Isso, claro, se o sujeito não exteriorizar por meio de atos concretos os seus desejos inconscientes, pois, se tal concretização ocorrer, responderá o agente pela prática, em tese, dos delitos sexuais previstos na Parte Especial do Código Penal de 1940 (estupro de vulnerável - art. 217-A, induzimento de menor de catorze anos à satisfação da lascívia de outrem - art. 218, caput, entre outros).

${ }^{359}$ EAGLEMAN, David. Incógnito: as vidas secretas do cérebro. Trad. Ryta Vinagre. Rio de Janeiro: Rocco, 2012. Após relatar um trágico caso em que um jovem norte-americano, fortemente armado, abriu fogo aleatoriamente contra pessoas na Universidade do Texas, resultando em 13 mortos e 33 feridos além da morte do próprio estudante (assassinado pela Polícia) - comportamento esse, infelizmente, corriqueiro dos Estados Unidos -, o autor faz uma análise da mudança de comportamento decorrente de danos cerebrais. Naquela ocasião, descobriu-se que o autor do desastre, alguém aparentemente normal, sofria de um tumor cerebral de grandes proporções, que foi determinante para o resultado produzido, o que foi confirmado por bilhetes escritos pelo mesmo atirador dois meses antes dos fatos, em que ele descrevia o sofrimento causado por suas tendências homicidas. Diante disso, o neurocientista lançou algumas interessantes indagações, que podem ser úteis à discussão sobre responsabilização penal e culpabilidade: "será que a descoberta do tumor cerebral de Whitman modifica seus sentimentos pelos assassinatos insensatos que ele cometeu? Se Whitman tivesse sobrevivido àquele dia, o tumor regularia a sentença que você consideraria adequada para ele? O tumor alteraria o grau de 'culpa' a que você considera dele? Não poderia você mesmo ter a falta de sorte de desenvolver um tumor e perder o controle sobre seu comportamento? (...) Para colocar no jargão jurídico: ele era imputável? Até que ponto alguém tem culpa se seu cérebro está lesionado de tal maneira que não lhe resta alternativa? Afinal, não somos independentes de nossa biologia, não é verdade?” (ob. cit., p. 165-166).

${ }^{360}$ Ob. cit., p. 166.
} 
Especificamente acerca da problemática da pedofilia, a obra traz o instigante caso de um homem heterossexual de quarenta anos, casado, cuja vida pessoal e profissional podia ser considerada saudável, que começa a desenvolver um repentino interesse de cunho pedófilo, inclusive envolvendo o consumo de pornografia infantil. Em face dessa constrangedora situação, ele buscou auxílio médico junto a um neurologista, quando se descobriu a existência de um tumor no córtex orbifrontal. Com a retirada do nódulo maligno, seu apetite sexual de matiz heterossexual e monogâmico voltou ao normal. Como seis meses depois, os impulsos pedófilos retornaram, uma nova cirurgia para a extirpação de um resquício do tumor restabeleceu a normalidade.

Com isso, pode-se notar que a "repentina" pedofilia que acometeu aquele indivíduo acaba sendo um demonstrativo da enorme - e, no mais das vezes, incontrolável - influência de aspectos biológicos atinentes ao complexo sistema cerebral de alguém sobre a tomada de decisões humanas. ${ }^{361}$

Ora, diante dessa constatação, é preciso levar em conta esses aspectos para fins de exame da responsabilidade penal de pessoas portadoras dessa grave parafilia. Ou seja, a disciplina jurídica das modalidades delitivas relacionadas com o abuso ou a exploração sexual infanto-juvenil não pode, a nosso ver, prescindir de uma profunda análise de todos esses vetores de influência para compreender a mente do pedófilo. Afinal, se uma leve mudança no equilíbrio da química do cérebro pode causar grandes mudanças no comportamento, como no caso mencionado, fica a dúvida se todos realmente somos livres para as escolhas socialmente corretas.

\footnotetext{
361 Ressalta o autor que "os impulsos que você toma por certos ('Sou hetero/homossexual', 'sou agressivo/tranquilo') dependem de pormenores intrincados de sua máquina neural. Embora agir segundo estes impulsos seja popularmente considerado uma questão de livre-arbítrio, o exame mais apressado das evidências demonstram os limites deste pressuposto." E por fim, conclui que "desejos ocultos podem espreitar escondidos por trás da máquina neural de socialização. Quando o lobo frontal é comprometido, as pessoas tornam-se 'desinibidas', desmascarando a presença de elementos mais fracos da democracia neural. Seria correto dizer que Alex era 'fundamentalmente' um pedófilo, meramente socializado para resistir a seus impulsos?'. Ob. cit., p. 167.
} 
Óbvio que a questão que se coloca, nesse ponto, atina com a antiga discussão acerca do alcance de ideias como culpabilidade, reprovabilidade, liberdade, impossibilidade de conduta diversa e do próprio sistema de imputabilidade/responsabilidade penais das sociedades ocidentais, bem como das relações desses conceitos com as proposições das neurociências. Isto é, desde há muito os estudiosos do Direito Penal vêm se debruçando sobre a dicotomia "livre-arbítrio $x$ determinismo" para delimitar campos de incidência da norma penal, buscando verificar até que ponto a tomada de decisões humanas estaria comprometida por fatores irracionais absolutos (genéticos, por exemplo) e sobre os quais o indivíduo não teria controle ou capacidade legítima de disposição.

Por isso convém citar o raciocínio de WINFRIED HASSEMER, em obra dedicada ao desenvolvimento das neurociências e suas possíveis consequências para o Direito Penal, pelo qual, a despeito da inegável importância da metodologia empírica das ciências naturais, o conceito normativo de liberdade/responsabilidade para fins de imputação penal ainda deve prevalecer. $^{362}$

Após fazer uma análise dos sistemas de imputação objetiva e subjetiva decorrentes da dogmática jurídico-penal, o autor estabelece as bases teóricas para refutar a adoção dos critérios deterministas para aplicação do direito penal, pois "quem, seja por qual motivo, nega que a pessoa possa ser responsável por aquilo que ela faz retira uma pedra angular não apenas de nossa ordem jurídica, senão também de nosso mundo. Atinge, assim, as bases normativas de nossos contatos sociais, o reconhecimento como pessoa. A base desse reconhecimento é a

\footnotetext{
362 Nesse aspecto, o autor traz interessante pensamento sobre a relação entre as diferentes ciências e o que considera um erro categorial acerca do delineamento da noção de 'liberdade': "diversas ciências têm uma concepção de liberdade, e suas concepções não estão, entre si, de acordo. Elas variam a depender das tarefas e convencimentos fundamentais que uma ciência reconhece para si e de acordo com o método e os instrumentos de pesquisa que deles deduz (...). Ciências que trabalham empiricamente têm problemas específicos com a concepção de liberdade. Seus instrumentos não se adéquam a esta concepção (...). Agora posso descrever sucinta e precisamente meu conceito de erro categorial. Esse erro consiste em assumir que ciências que trabalham empiricamente poderiam cientificamente descobrir se outras ciências devem ou não desenvolver uma concepção de liberdade, ou seja: se essa liberdade 'existe' ou não. Uma tal concepção pressupõe obrigatoriamente uma hegemonia entre as ciências, e essa hegemonia não existe. Tampouco existe uma concepção geral de liberdade, que paire sobre todas as ciências, e tampouco existiria um poder de estipulação das ciências empíricas, caso houvesse uma tal concepção." HASSEMER, Winfried. Neurociencias y culpabilidad en Derecho Penal, InDret 2/2011, p. 7-8, Barcelona, trad. Manuel Cancio Meliá, disponível em http://www.indret.com/pdf/821.pdf. Segundo informações obtidas, esse artigo já possui tradução em português por HELENA REGINA LOBO DA COSTA, no entanto ainda não foi publicado no Brasil, estando prevista para a edição do primeiro trimestre de 2013 da Revista Brasileira de Ciências Criminais.
} 
expectativa mútua de que o encontro humano ocorre não como um sistema de ossos, músculos e nervos, mas que o outro percebe-nos igualmente como pessoa e se guia de acordo com essa percepção".

Continuando em sua crítica, assevera que "imputamos ao outro, quando não há contraindicações aparentes, a responsabilidade que experimentamos em nós mesmos e da qual nos valemos - não porque humanocientificamente ela foi confirmada ou refutada, mas porque, sem esse crédito mútuo, não conseguiríamos viver uns com os outros. (...) Isso tudo nós fazemos não porque ainda tomamos conhecimento ou compreendemos a mais recente reputação humano-biológica da responsabilidade; (...) Isto porque responsabilidade e imputação não repousam em conhecimentos humano-biológicos, mas em razões sociais. Elas não sobrevivem de desconhecimento e irracionalidade, mas de juízo e experiência". 363

Mais ao final, ao mencionar a previsão jurídico-penal das causas excludentes da culpabilidade no sistema penal alemão, mesmo autor conclui que tais circunstâncias são "constelações nas quais o direito penal e as ciências empíricas sobre as pessoas se tocam, ou se atravessa. O campo dessas categorias está aberto no futuro. Seu objeto é o resultado de desenvolvimentos a longo prazo nas ciências empíricas, mas também da decisão penal sobre a relevância de tais desenvolvimentos para a imputação de culpabilidade penal" ${ }^{364}$. Em suma, na sua visão, o legislador pode utilizar critérios das ciências naturais para fins de responsabilização penal, valorando-os, havendo aí um uso necessário dos conhecimentos próprios da seara empírica. No entanto, isso não significa a ausência absoluta de liberdade de ação humana (e, por consequência, de imputação penal), sob pena de ameaça ao próprio sistema penal como um todo.

Essa tomada de posição, em certa medida, é compartilhada por LUZÓN PEÑA, o qual, em artigo dedicado ao mesmo tema, após trazer um detalhado histórico a respeito da culpabilidade (trazendo desde as noções clássicas até as opiniões atuais sobre as concepções de liberdade/reprovabilidade/responsabilidade), pontua que, a não ser em situações de

\footnotetext{
${ }^{363}$ HASSEMER, Winfried. Neurociencias..., ob. cit., p. 9.

${ }^{364}$ Ob. cit., p. 10.
} 
anormalidade funcional do cérebro de alguém, essa pessoa tem a capacidade natural a todo ser humano - daí a diferença com relação aos outros animais - de ser dona de suas próprias escolhas, portanto, livre.

Com efeito, segundo suas palavras, "a liberdade de escolha do indivíduo é a capacidade, adquirida progressivamente pelo processo de educação, maturação e socialização e graças à capacidade racional de motivação e autocontrole, de ser dono de seus próprios atos - naturalmente dentro dos limites do que é humanamente factível -, em vez de um mero fantoche das circunstâncias, de impulsos inconscientes e outras condições, a menos que concorram fatores totalmente anormais que impeçam ou perturbam dita capacidade da vontade consciente. $" 365$

E mais adiante, completa que o correto seria adotar a posição doutrinária do fundamento misto da culpabilidade: empírico (sociológico, antropológico) e normativo, despontando a liberdade humana como base da culpabilidade. E dessa maneira, pode-se prescindir da necessidade de demonstração, mediante experimentos ou comprovações físicobiológicas da existência (ou não) de liberdade de todo e qualquer indivíduo na situação concreta $^{366}$. Com isso, haveria uma ideal combinação entre o conhecimento das ciências naturais e os critérios de culpabilidade jurídico-penal baseados na vivência e experiência sociais em um determinado lugar e período.

Assim, trazendo os posicionamentos acima apontados ao objeto em discussão, a aproximação entre as neurociências e o estudo da dogmática penal é uma tendência atual, salutar para a elucidação de casos concretos nos quais o indivíduo realmente tenha sido acometido de fatores anômalos determinantes à sua conduta delituosa. A utilização desses conhecimentos empíricos, em uma seara tão sensível como a que envolve casos de pedofilia,

365 LUZÓN PEÑA, Diego-Manuel. Libertad, culpabilidad y neurociencias. InDret 3/2012, p. 36, Barcelona, jul./12, disponível em http://www.indret.com/pdf/904a.pdf (tradução livre). O mesmo autor completa o raciocínio com a seguinte constatação: "este domínio dos próprios atos e controle dos impulsos e emoções profundas é algo que, como sabido, pode-se adquirir paulatinamente mediante o uso de remédios ou substâncias, bem como pelo uso de diversas técnicas de ajuda psicofisiológicas como treinamento, yoga, meditação profunda ou introspecção" (ob. cit., p. 36, tradução livre). Interessante a menção a técnicas de autocontrole mental como a milenar prática do yoga, muito difundida no mundo oriental, e que realmente pode ser de alta utilidade no auxílio ao tratamento de pessoas portadoras de parafilias, como a aqui tratada pedofilia.

${ }^{366}$ LUZÓN PEÑA, ob. cit., p. 36/37. 
aparece como um instrumento importante. Entretanto, há de destacar as posições de HASSEMER e LUZÓN PEÑA no sentido de que a noção de culpabilidade normativa ainda está vigente, não havendo que se falar em determinismo absoluto ou ausência de livre-arbítrio em termos jurídicos. As pessoas continuam responsáveis por seus atos, só que o desenvolvimento dos estudos científicos do cérebro e de seus infindáveis mistérios ainda será de extrema valia à ciência penal, aparecendo como um auxílio à solução de casos complexos no dia a dia forense.

Justamente por isso, repita-se, é imperioso, para fins de delimitação de responsabilidades, ter em mente que o pedófilo, mais do que criminoso ou desajustado socialmente, pode padecer de algum grave distúrbio neurológico, cujos impulsos sejam irresistíveis. Nessas hipóteses, caso haja procura ou consumo de material pornográfico infantil, vê-se que a questão extrapola o viés jurídico e reclama uma abordagem clínica, externa ao mundo jurídico. ${ }^{367}$

De outro lado, nem todos os envolvidos com pornografia infantil serão considerados, necessariamente, doentes ou enfermos mentais, incapazes de terem consciência do eventual caráter ilícito de seus atos. Por isso que será preciso analisar - caso a caso -, por meio da realização de laudo pericial oficial, até que ponto se pode falar em inimputabilidade, ou semiimputabilidade. $^{368}$

\footnotetext{
${ }^{367}$ Repise-se: muito embora o objeto desse estudo seja meramente dogmático, parece importante ao menos citar a existência desse tipo de transtorno mental, até para se tentar arrefecer as posturas intolerantes ou estigmatizantes no campo dos crimes sexuais. Com isso, não se está absolutamente a advogar a tese da "absolvição geral" dos autores desse gravíssimo tipo de ofensa. No entanto, é preciso cautela e a verificação caso a caso de todos esses fatores biológicos envolvidos. O aprofundamento da questão sobre a aplicação de critérios de inimputabilidade escapa ao tema da presente monografia, mas merece essa breve menção.

${ }^{368}$ Essa afirmação encontra eco nas palavras de JÚLIO CÉSAR FONTANA ROSA, o qual, ao proferir parecer médico em caso concreto envolvendo um rapaz de vinte e oito anos preso por fotografar garotos enquanto estes tomavam banho, estabeleceu uma distinção entre os pedófilos e os exploradores da indústria da pornografia infantil, ressaltando que "já havíamos concluído que se tratava de uma doença e que deveria ser motivo de uma outra abordagem médico-psiquiátrica orientando a sentença. Entendia-se que o examinando era capaz de entender o caráter ilegal do fato, mas não era capaz de determinar-se de acordo com esse entendimento. (...) Se a doença dificulta o surgimento de escrúpulos por parte do doente, o lucro vai impedir que isso aconteça com o profissional explorador não pedofílico. Este último pode atingir requintes inimagináveis para obter lucros. (...) Os dados atuais são conclusivos de que a pedofilia é um evento comum e bastante conhecido por causar problemas a curto e a longo prazo para as vítimas. De fato, são nocivos, no entanto são doentes e então, tem que ser atendidos na medida que a lei determina. Se por outro lado, estamos frente a exploradores, a distinção deve ser feita e caberá a esses pena de prisão, visto que não são movidos pelos instintos patológicos, mas sim pelo interesse no
} 
Aliás, a própria utilização indiscriminada do termo pedófilo para designar todos aqueles envolvidos de alguma forma com pornografia infantil não fica imune a críticas, uma vez que, mesmo naquelas hipóteses em que o cidadão nem chegou a abusar ou atacar sexualmente alguma criança ou adolescente, o senso comum acaba tachando-o de doente.

Ora, esse alargamento da noção de pedofilia parece um tanto inadequada à medida que equipara indivíduos em distintas posições. Nesse passo, designar alguém, que sequer teve contato pessoal com alguma criança ou adolescente, como pedófilo traz, em si, todo aquele ranço preconceituoso já abordado no capítulo acerca da moral sexual. Por isso que, a nosso ver, deve ser estabelecida essa diferença.

\subsection{O perfil do pedófilo e do consumidor desse tipo de material: semelhanças e diferenças}

Como já adiantado, é preciso deixar bem claro que nem todo agressor sexual ou consumidor de material pornográfico infantil é pedófilo, ou seja, alguém que padeça da parafilia marcada pelo desejo sexual irrefreável de excitar-se sexualmente por crianças e adolescentes. São pessoas que apresentam perfis, no mais das vezes, distintos, de modo que se mostra necessário estabelecer essa importante diferenciação.

De outro lado, nem todo pedófilo equipara-se à figura do abusador violento, do violador sexual que se utiliza de sua superioridade física, da grave ameaça ou de ardil para seduzir um menor e com ele manter atos libidinosos.

Com efeito, muito embora possa parecer um contrassenso, há diversos casos de indivíduos com impulsos pedófilos, marcados por forte desejo sexual por crianças e

lucro.” ROSA, Júlio César Fontana. Pedofilia. Em: Revista do Curso de Direito, Espírito Santo do Pinhal, v. 3, p. 45, jan/dez. 2011. 
adolescentes e que podem viver sem colocar em prática suas fantasias libidinosas. Por isso um pedófilo não é obrigatoriamente um criminoso.

Talvez pela atualidade do tema da pedofilia, inclusive objeto de recente Comissão Parlamentar de Inquérito no Brasil - como já destacado -, a imprensa vem retratando a complexidade de se tratar o problema da pedofilia e do abuso sexual infantil sob os diversos enfoques. Inclusive o papel do próprio agressor, que, na grande parte das vezes, apenas recebe o rigor da lei penal, ignorando-se a relevância de tratamento para essas pessoas ou então a mera busca de compreensão psicológica dessa doença.

Em reportagem recente, o jornal "Folha de São Paulo" publicou, no caderno "equilíbrio", matéria relatando a existência, até então pouco noticiada, de associações de profissionais no exterior cujo foco repousa no devido tratamento de abusadores infantis em potencial, colimando-se evitar a posterior prática de efetivos atos criminosos. Com o título "Pedófilos no limite", a matéria retrata os ativistas que querem prevenir a violência sexual contra crianças, "oferecendo compreensão e tratamento a portadores do transtorno que ainda não passaram da fantasia ao crime". O mote que se coloca pode ser sintetizado na pergunta: "é a vitimização do agressor?". 369

O ponto relevante abordado pela reportagem, e que auxilia na elaboração da presente monografia, é a descoberta de que, em outros países ${ }^{370}$, há entidades, voluntariadas ou não, compostas por profissionais da saúde (médicos psiquiatras, enfermeiros etc.), psicólogos, psicanalistas entre outros, que têm como preocupação oferecer ajuda aos portadores desse grave desvio sexual que queiram buscar a cura completa ou ao menos a amenização dos sintomas.

\footnotetext{
${ }^{369}$ Reportagem publicada na edição de 14 de agosto de 2012, caderno "equilíbrio", p. 4.

${ }^{370}$ Por exemplo, no reino Unido e na Irlanda, surgiu o grupo "Stop It Now!", que disponibiliza um número de telefone para quem tem consciência de seu problema e precisa de ajuda para continuar inofensivo.
} 
Mesmo figurando na contramão da opinião pública - que é, por óbvio, estimulada em grade parte pela campanha de demonização constante dos meios de comunicação $^{371}$ - e sofrendo o preconceito às avessas por realizar esse tipo de trabalho ${ }^{372}$, essas associações têm obtido certa parcela de sucesso nos tratamentos, o que acaba sendo um bom sinal diante da desconfiança (e, por que não, do preconceito) geral da população acerca dessa atividade ${ }^{373}$.

No Brasil, o Centro de Estudos Relativos ao Abuso Sexual, com sede em São Paulo, fornece atendimento e ajuda a famílias marcadas pelo incesto ou pelo abuso sexual infantil no âmbito doméstico. De acordo com o médico psiquiatra José Raimundo Lippi, presidente da Associação Brasileira de Prevenção e tratamento das Ofensas Sexuais, é fundamental dar suporte aos que sofrem do transtorno - no mais das vezes, pessoas solitárias, imaturas e com dificuldade de interação social - a fim de se evitar a futura exteriorização de seus desejos libidinosos. ${ }^{374}$

\footnotetext{
${ }^{371}$ O problema da influência midiática na construção da figura do pedófilo como inimigo, como uma ameaça constante contra a juventude como um todo, foi objeto de análise por PEDRO PAULO FERREIRA, segundo quem "o senso comum transmitido pelos meios de comunicação, especialmente os televisivos, contribui para que o imaginário popular creia na indiferenciação entre o pedófilo e o delinquente sexual ocasional ou habitual. A notícia não busca identificar em seus holofotes as particularidades de cada suspeito de violência sexual infantojuvenil. (...) Idêntico enfoque tem aquele que, surpreendido com inesgotável quantidade de material pornográfico infantil, já de imediato é apontado como o idealizador ou produtor da referida pornografia". Ob. cit., p. 109-110.

${ }^{372} \mathrm{Na}$ França, o episódio vivenciado por uma franco-argelina com vasta experiência no assunto (muito embora não tenha formação em psicologia), Latifa Benari, mostra as enormes dificuldades encontradas no início das atividades da associação L'Ange Bleu, que trata pedófilos na busca do controle de seus instintos, possibilitandolhes uma vida praticamente "normal". Em 1998, ansiando chamar a atenção para a causa, Latifa decidiu participar de um congresso de psicologia para expor seus pontos de vista. O resultado foi uma rejeição unânime: "todos me chamaram de louca, disseram para não focar no pedófilo, e sim na vítima. O objetivo era justamente evitar vítimas, mas disseram não ser politicamente correto. Achavam impossível um pedófilo sair das sombras antes de virar criminoso". Daí já é possível verificar a grande resistência da sociedade - inclusive no universo médico - em encarar o problema sob outro ângulo. De novo, sempre que o assunto é crime sexual, parecem emergir os mesmos estigmas e rótulos moralmente condenáveis de épocas passadas. E o mais interessante é observar, segundo o relato da presidente da entidade francesa, que "hoje, num dia normal, Benari atende em média sete novos pedófilos em potencial". Ou seja, talvez as pessoas estejam tomando consciência de que o melhor remédio pode ser a prevenção, ao invés da mera repressão penal.

373 PEDRO PAULO FERREIRA, citando assevera que "lamentavelmente, a opinião pública está permeada pelo sentido comum imposto pelos discursos oficiais e dos meios de comunicação, segundo os quais a melhor alternativa para conservar a ordem, e neste caso a intangibilidade sexual de crianças e adolescentes, é a suspensão das garantias e o aumento das medidas repressivas" (Um estudo acerca das relações..., ob. cit., p. 109).

${ }^{374}$ Um dado estatístico significativo trazido pela matéria, segundo o psicólogo Antonio Serafim, do Hospital das Clínicas de São Paulo: a literatura aponta que ao menos $\mathbf{7 5 \%}$ dos pedófilos nunca chegam a sair da fantasia para o crime. Como se percebe, os pedófilos não-abusadores constituem considerável maioria no universo dos que padecem desse transtorno. Diante dessa informação, os esforços da sociedade, a nosso ver, deveriam ser envidados no sentido de aumentar essa porcentagem de pedófilos "controlados" por meio da divulgação do problema e do oferecimento de eficaz tratamento. Infelizmente, essa não parece ser a prioridade de nosso sistema
} 
Sobre o incesto presente no ambiente doméstico - infelizmente, bastante frequente, ainda mais se se constatar abuso de álcool e outras drogas -, o autor ressalta o caráter preventivo do trabalho do referido Centro decorrente do tratamento psicológico oferecido. $\mathrm{O}$ escopo é de tentar realizar a reconstrução psicológica de crianças e adolescentes, logo no começo, quando surgir um caso de incesto familiar. Segundo Lippi, "fazemos ações anteriores ao aparecimento da patologia. A família incestuosa é uma fábrica de ofensores sexuais: ali são produzidos futuros pais incestuosos, pedófilos, estupradores etc. Trabalhar com essas famílias é fazer a prevenção primária desse grave problema de saúde pública". 375

Outro importante exemplo que demonstra o esforço da comunidade médica brasileira no tratamento de pessoas com transtornos de sexualidade é o Ambulatório de Transtornos de Sexualidade da Faculdade de Medicina do ABC (ABSex), em Santo André, comandado pelo Psiquiatra Danilo Baltieri. Nesse Centro, é comum o atendimento a pessoas que sofrem dessa parafilia e que, cientes da gravidade de seu problema psiquiátrico, desejam tratamento adequado para ao menos arrefecer suas fantasias pedófilas. ${ }^{376}$

Vale fazer uma observação quando o assunto tratado embarca a possibilidade de transformar futuros agressores em pedófilos "inofensivos" ou controlados: todos os profissionais envolvidos são uníssonos em ressalvar que o primeiro passo para o tratamento deve partir da iniciativa própria do doente, que precisa admitir a existência (e a gravidade) de seu problema e concordar em se submeter ao tratamento.

Outro dado trazido pela reportagem de bastante utilidade à nossa tese diz respeito com o relato comovente de pessoas portadoras do sério desvio e que, conscientes de seu permanente estado enfermo, conseguem controlar-se e manter seus desejos no campo do

de saúde (público e privado), muito menos da população, que prefere trilhar o caminho menos árido da condenação moral.

${ }^{375}$ Cf. reportagem publicada na edição de 14 de agosto de 2012, caderno "equilíbrio", p. 5.

376 Segundo declarações de Danilo publicadas em matéria jornalística, "Não sou contra punir as pessoas que cometem esse crime, mas acho que elas têm o direito ao tratamento médico". (...) O centro médico é um dos pioneiros no País no uso de injeções hormonais em pedófilos. "Tenho vários pacientes que hoje levam uma vida normal” (disponível em http://www.istoe.com.br/reportagens/194141_CERCO+AOS+PEDOFILOS). 
imaginário. Um traço comum entre eles é a capacidade, mediante muito esforço, de compreender a sua doença e autodeterminar-se segundo as regras legais, deixando o seu desejo proibido apenas na esfera da fantasia ${ }^{377}$. Interessante notar que todos os ouvidos declararam repúdio aos agressores sexuais, os quais, consoante a opinião dos pedófilos, são motivo de vergonha e injusta generalização por parte do senso comum $^{378}$. O amor que sentem por crianças e adolescentes, a propósito, acaba sendo o principal móvel para eles admitirem o problema e buscarem o tratamento especializado, evitando-se os irreparáveis prejuízos ao saudável desenvolvimento de menores em caso de realização das fantasias sexuais.

Apenas para corroborar a abissal distância entre o pedófilo consciente e o criminoso sexual, convém observar o sincero relato de um dos entrevistados, um homem casado de quase 40 anos, segundo quem "tenho plena consciência do mal que poderia causar se cedesse à tentação. (...) O que me diferencia dos pedófilos que abusam de crianças é uma coisa só: escolha. Se eu agisse na direção dos meus desejos, poderia ser muito nocivo." 379

Em outras palavras, chega até a causar espécie que portadores de pedofilia, pessoas já tão condenadas pelo senso geral por causa de um transtorno que acaba fugindo de seu autocontrole, possam ter a clareza consciente de que, em nome daquela atração irresistível, nunca colocariam em práticas seus instintos perversos exatamente para poupar seu objeto de desejo de sofrer danos.

\footnotetext{
${ }^{377}$ Em reportagem abordando uma pesquisa suíça sobre consumo de pornografia infantil e violência sexual, o tratamento desses impulsos pedófilos é possível. Segundo o psicanalista alemão Klaus Beier, os pedófilos podem aprender a controlar sua tendência sexual. "É tarefa dos atingidos aprender que podem fazer tudo na fantasia, mas não na realidade", disse Beier à agência de notícias EPD. Cf. matéria disponível em http://www.swissinfo.ch/por/Capa//Internet_da_nova_dimensao_a_pedofilia.html?cid=6899442 (acesso em 09 de outubro de 2012).

${ }^{378} \mathrm{Um}$ dos casos retratados na reportagem apresenta uma situação inusitada: um homem de 35 anos de idade foi preso em flagrante por possuir material pornográfico em seu computador pessoal. No entanto, por mais paradoxal que possa parecer, sua prisão e a vergonha de ter seus desejos pedófilos escancarados diante da família acabaram tendo um efeito positivo de alívio, pois a partir dessa ocasião, ele pôde reconhecer o problema e procurar ajuda psicológica para tratar seus instintos. Ele ingressou no grupo francês L'Ange Bleu e, desde então, vem apresentando avanços em seus bloqueios e no seu medo de relacionar-se com adultos. Ao final, arremata que "jamais pensei em abusar de uma criança, meu desejo nunca saiu da penumbra do meu apartamento. (...) Eu jamais poderia ser o responsável por tamanha tristeza na vida de alguém. Por outro lado, esses grupos [como a referida associação francesa] sabem fazer a diferença entre pedófilos como eu, que não passam ao ato. E se eles conseguem, acho que a sociedade deveria conseguir também". Reportagem publicada na edição de 14 de agosto de 2012, caderno "equilíbrio", p. 6.

${ }^{379}$ Matéria jornalística citada, p. 5.
} 
Mais do que isso, uma parcela desses mesmos indivíduos, tão hostilizados e repudiados pela sociedade, são capazes de separar as situações e apontar o abuso sexual como algo consciente, admitido pelo agente criminoso, e fonte de inesgotável sofrimento psicológico para os ofendidos.

De outro lado, vale trazer o enfoque agora para aquelas pessoas que, inobstante sejam abusadores sexuais, não necessariamente são pedófilos, já que não diferenciam vítimas menores de adultas, tendo como foco a prática de atos violentos ou constrangedores para saciar suas âncias sexuais muitas vezes de forma totalmente egoística.

Nessa classe específica de agressores sexuais, percebe-se até um grau maior de reprovabilidade, visto que agem de modo consciente e com o intuito próprio de atingir a dignidade sexual das vítimas, independentemente se são adultas, adolescentes ou crianças. Para esses casos, a atração preferencial por menores impúberes - traço comum àqueles acometidos pela parafilia em questão - acaba não sendo o motivo determinante da agressão sexual, senão a vontade livre de submeter o ofendido aos seus caprichos sexuais.

\subsection{Eventuais tratamentos}

Diante do apresentado, apesar da impossibilidade de apontamento de respostas absolutas às questões decorrentes da figura do "pedófilo", diretrizes podem ser pensadas a fim de estimular a discussão de ideias acerca de prováveis resoluções para as controvérsias que surgem nesse assunto. Importante destacar, uma vez mais, que esses tratamentos seriam cabíveis apenas para os indivíduos que fossem flagrados portando pornografia infantil real, já que as hipóteses de pornografia simulada, como abordado, configuram um irrelevante penal, diante de sua atipicidade.

Com efeito, identificada a questão, cabe perquirir o quê fazer com esses sujeitos, como o Estado deve tratá-los, e de que maneira os meios de controle estatal poderão atuar para, ao 
mesmo tempo, proteger os interesses dos jovens e das crianças objeto das manifestações (e da própria sociedade como um todo) e também prestar auxílio àqueles que desejam tratar do desvio sexual (moléstia psicológica). A doutrina, apesar de parca sobre o assunto, tenta apresentar algumas soluções.

Diante desse quadro, teríamos, em regra, três possibilidades: $i$ ) aplicar a letra fria da lei, submetendo o portador dessa grave parafilia às sanções penais, claro que após o devido processo legal; uma vez cumprida a pena, ele voltaria ao convívio social; $i$ ) diante da gravidade do quadro psíquico do agente, reconhecer a sua inimputabilidade, aplicando-lhe medida de segurança por tempo indeterminado (art. 26 do CP); ou então iii) se ele detiver parcial ausência de capacidade de entender o caráter criminoso de seus atos, haveria redução de pena (nos moldes do artigo 26, parágrafo único, do Diploma Penal).

Com relação à primeira eventual solução, muito embora o assunto ainda não esteja definido, por tudo o que se afirmou até o momento, não parece uma das mais adequadas. Além de não resolver a situação do agente, apenas reforçaria, diga-se uma vez mais, o caráter estigmatizante do Direito Penal, submetendo o cidadão a um verdadeiro calvário judicial e/ou prisional. Mais do que isso, deixar-se-ia de lado toda uma gama de características que marcam um Direito Penal humanista em um dito Estado de Direito. ${ }^{380}$

Já a segunda e terceira opções parecem adequar-se melhor aos ditames do ideal de justiça e paz social informadores de nosso sistema jurídico-penal. Sim, pois, uma vez detectada a parafilia que acomete o agente, e o seu grau de intensidade, estará ele sujeito à medida de segurança (tratamento ambulatorial ou, em último caso, internação) ${ }^{381}$, ou então a diminuição da reprimenda, tudo nos termos do artigo 26 do Código Penal. ${ }^{382}$

\footnotetext{
${ }^{380}$ As ideias de MÁRIO FURLANETO NETO parecem coadunar-se com esse raciocínio. Após apontar os aspectos científicos e médico-legais sobre o assunto, ponderou que "necessário se fez pontuarmos as bases do termo pedofilia, pois o Direito Penal não tutela a criança e o adolescente contra condutas que se amoldam ao sentido etimológico do termo, mas tão-somente as ações ou omissões que (...) caracterizem, sob a ótica da Medicina Legal e da Psiquiatria, um comportamento sexual anormal. Em decorrência, tem-se que os crimes praticados contra a criança ou adolescente (...) podem ser praticados por agente portador de pedofilia, mas nem todo autor dos crimes em espécie pode ser considerado um pedófilo.” Ob. cit., p. 7.

381 Aqui vale um alerta de cunho prático: são conhecidas, no Brasil, as mazelas constantes dos manicômios judiciários. Por isso, deve ser vista com certa cautela a aplicação de medida de segurança de internação nesses
} 
Nesse particular, vale uma rápida menção à possibilidade de importar conceitos da chamada "Justiça Terapêutica", ideia afeita à abordagem político-criminal dos delitos relativos à posse de substância entorpecente para uso próprio no Brasil. Como se sabe, o usuário de drogas, após o advento da Lei 11.343/06, deve ser visto e tratado como um doente, que merece tratamento, e não repressão penal.

A título de sugestão, poder-se-ia pensar um sistema jurídico parecido para o portador de pedofilia, sendo até aconselhável que o Estado brasileiro, por meio de seu sistema público de saúde, pudesse oferecer tratamento e acompanhamento psiquiátrico ao portador desse grave mal. $^{383}$

JORGE TRINDADE e RICARDO BREIER trazem sugestão similar ao aventarem a possibilidade de imposição de medida de segurança ou redução de pena, já que "o tratamento jurídico penal, para casos associados á pedofilia, determinar-se-á pelos traços psíquicos, os quais poderão confirmar se o pedófilo é um agente inimputável (...) ou semi-imputável (...). A prova técnica se produz através da instauração do incidente de insanidade mental (art. 149 do Código de Processo Penal)., 384

estabelecimentos. Às vezes, o cumprimento da pena privativa de liberdade pode parecer mais humano do que o tratamento compulsório.

${ }^{382}$ Essa parece ser a orientação de ROBERTO SOARES GARCIA, para quem seria um "equívoco chamar-se a pornografia infantil ou juvenil de pedofilia, já que esta é uma doença que leva os seus portadores a serem considerados, em seara penal, semi-imputáveis ou inimputáveis (cf. art. 26 do Código Penal)." Notas sobre pornografia infantil ou juvenil praticada por meio da internet. Disponível na internet: http://www.ibccrim.org.br, em 09.12.2001. No mesmo diapasão o entendimento de MÁRIO FURLANETO NETO, cuja conclusão seria a de que "a pedofilia poderá ser objeto de abordagem no campo da inimputabilidade penal, nos termos do artigo 26 do Código Penal, sendo incorreto utilizar o termo para denominar o delito de publicar fotografias de conteúdo pornográfico infanto-juvenil." Ob. cit., p. 7.

383 Aliás, como é sabido ocorrer em alguns países, como na Alemanha. Essa informação foi trazida por DANILO BALTIERI em palestra dedicada ao tema da pedofilia, ministrada na seccional paulista da Ordem dos Advogados do Brasil, em 07 de junho de 2011. O mesmo autor, em obra dedicada ao estudo dos agressores sexuais brasileiros, revelou que o tratamento pode ser bastante eficaz e a medicação não traz prejuízos aos pacientes. Aliás, o autor lamenta que o tratamento hormonal para perigosos agressores sexuais seja considerado imoral em nosso país, até porque fatores de risco podem ser amenizados com tratamento adequado. BALTIERI, Danilo Antônio; ANDRADE, Arthur Guerra. Treatment of paraphilic sexual offenders in Brazil: issues and controversies. International. Journal of Forensic Mental Health, vol. 8, $3^{\text {a }}$ ed., p. 218-233, 2009.

${ }^{384}$ TRINDADE, Jorge; BREIER, Ricardo Ferreira. Pedofilia: aspectos psicológicos e penais. Porto Alegre: Livraria do Advogado, 2007, p. 110. 
Por fim, menção especial merece a existência de outra eventual medida de tratamento aplicável a pessoas que padecem dessa enfermidade, cuja proposta vem causando polêmica em virtude dos diversos aspectos imbricados: a chamada castração química. Cuida-se de um tratamento terapêutico temporário e reversível pelo qual se injeta um hormônio sintético feminino chamado Depo-Provera (acetato de medroxyprogesterona, ou DPMA), que reduz os níveis de testosterona, inibindo, assim, o desejo sexual (a libido) do indivíduo por aproximadamente seis meses. $^{385}$

No Senado Federal brasileiro, há um Projeto de Lei (PLS 552/2007), de autoria do senador GERSON CAMATA (PMDB-ES), no qual se prevê a modificação do Código Penal com a previsão expressa de cominação de "pena" de castração química para pessoas condenadas pela prática de crimes sexuais envolvendo crianças e adolescentes. ${ }^{386} \mathrm{O}$ tema seria regulamentado da seguinte forma: é necessária a voluntariedade do condenado à submissão ao tratamento durante o livramento condicional, se não for reincidente; se os resultados forem satisfatórios, prevê-se uma redução da pena; o período não pode ultrapassar; o lapso de tratamento não abarca o quantum da pena.

O referido Projeto de Lei sofreu duras críticas pelo psiquiatra DANILO BALTIERI, uma vez que tal controle hormonal foi apresentado como pena, enquanto a questão deveria ser encarada como tratamento, e não punição. Além disso, o médico afirmou que a terapia é reconhecida por entidades médicas, como a Associação Internacional para o Tratamento de

\footnotetext{
${ }^{385}$ GUDÍN RODRÍGUEZ-MAGARIÑOS, Faustino. Medidas legales..., ob. cit., p. 89.

${ }^{386}$ Seguem adiante a ementa e o inteiro teor do PLS 552/07: "Acrescenta o art. 216-B ao Decreto-Lei no 2.848 , de 7 de dezembro de 1940 - Código Penal, para cominar a pena de castração química nas hipóteses em que o autor dos crimes tipificados nos arts. 213, 214, 218 e 224 for considerado pedófilo, conforme o Código Internacional de Doenças. Art. $1^{\circ}$ Fica acrescido ao Decreto-Lei n ${ }^{\circ} 2.848$, de 7 de dezembro de 1940 - Código Penal, o art. 226-A: Art. 226-A. Nas hipóteses em que o autor dos crimes tipificados nos arts. 213, 214, 218 e 224 for considerado pedófilo, conforme o Código Internacional de Doenças, fica cominada a pena de castração química. Art. $2^{\circ}$ Esta Lei entra em vigor na data de sua publicação." A Justificação apresentada pelo congressista apontado deixa claro o propósito do projeto: "A pedofilia é uma doença reconhecida pela comunidade científica internacional, que a descreve em seu Código de Doenças, cujas consequências para a sociedade têm sido das mais gravosas. Menores são psicológica e fisicamente torturados por indivíduos cuja formação psíquica apresenta tal deformidade a ponto de os impedirem de reabilitar-se perante a sociedade, mesmo se submetidos aos mais modernos e refinados tratamentos clínicos. (...) O projeto em tela visa a debelar essa mazela social em sua origem, com a máxima objetividade e o necessário vigor, em prol da sociedade."
} 
Agressores Sexuais, e disse rejeitar o nome "popular" do tratamento. Para ele, o termo "castração" dá a entender que se trata de uma medida imposta e com efeitos permanentes. ${ }^{387}$

Também existem dúvidas a respeito da constitucionalidade da medida, diante da afronta direta ao princípio da dignidade da pessoa humana (art. 1. ${ }^{\circ}, \mathrm{III}, \mathrm{da} \mathrm{CF} / 88$ ), bem como da vedação de penas cruéis (art. 5., XLVII), porque o tratamento afetaria o paciente de forma a causar-lhe efeitos colaterais graves (depressão, fadiga crônica, diabetes etc.). Na realidade, a castração química equivaleria a tratamentos cruéis tão condenados no passado, como é o caso da lobotomia, com o intuito de acalmar os doentes mentais.

Argumentos em sentido contrário podem ser invocados, tais como o fato de se cuidar de tratamento não-obrigatório, com nítido caráter terapêutico e que preserva a dignidade do condenado por ser algo provisório e reversível. ${ }^{388}$ Ademais, busca-se justamente curar (ou ao menos amenizar) os efeitos deletérios da doença.

Finalmente, convém apenas esclarecer que tal medida, na forma como prevista no referido projeto de lei, seria cabível somente para os casos de efetiva violência praticada contra crianças e adolescentes, nada prevendo sobre a hipótese de pornografia infantil. De qualquer maneira, poderia aparecer como mais uma opção ao sistema punitivo de enxergar o pedófilo como pessoa necessitada de tratamento, e não de sanção criminal.

Os debates ainda estão apenas no início. Seja como for, por meio da aplicação de pena ou medida de segurança, o mais importante será a mudança de paradigmas. Analisar, compreender e tratar a situação de pessoas "consumidoras" de material pornográfico infantil real sob um viés médico-psiquiátrico parece ser a forma mais correta de se pensar o assunto. ${ }^{389}$

\footnotetext{
387 Cf. entrevista concedida ao jornal O Estado de São Paulo, em 16/10/2007. Disponível em http://www.gtpos.org.br/index.asp?Fuseaction=Informacoes\&ParentId=511\&area=28\&pub=167. $\quad$ Curioso observar que tal método de tratamento já é previsto em alguns Estados nos EUA, como a Califórnia, e há projetos em curso de implementação em países como a França e a Espanha.

${ }^{388}$ Essas diferentes maneiras de abordar a questão foram destacadas por ELIZABETH BAYMA PEREIRA em artigo intitulado "Castração química: análise do Projeto de Lei n552/2007 à luz da Constituição Federal", disponível em: http://jus.uol.com.br/revista/texto/17166/castracao-quimica.

${ }^{389}$ Tanto isso é verdade que ALEXANDRE ASSUNÇÃO E SILVA, ao fazer comparação da posse de pornografia infantil real com o consumo de entorpecente, destaca que "entendemos que assim como o traficante de drogas deve receber repressão severa e o usuário tratamento, quem produz ou divulga material pornográfico
} 
O mais importante, afinal, é destacar que, de acordo com o conhecimento científico, o cidadão que sofre desse tipo de parafilia deve ser encarado como alguém que necessita de tratamento médico, e não, necessariamente, da interferência do Direito Penal por meio da aplicação de uma pena privativa de liberdade.

Repita-se, nem todo pedófilo é abusador de crianças ou adolescentes, ou difusor de material pornográfico infantil real, já que pode haver hipóteses em que a obsessão não se exterioriza na prática de atos concretos a colocar em risco a tutela do interesse que se busca proteger com a criminalização de condutas relacionadas à pornografia infantil, qual seja, o direito de desenvolvimento sadio de crianças e adolescentes.

Esses são, em apertada síntese, os aspectos médico-legais possíveis para uma aproximação interdisciplinar que teria como foco a tentativa de trazer soluções mais humanas ao problema da pedofilia que tanto aflige a sociedade atual.

infantil deve sofrer penas duras, e quem adquire tal material ser submetido a tratamento e medidas sócioeducativas." E traz a seguinte sugestão prática: “isso, no caso de quem adquire pornografia infantil, será possível se houver a suspensão condicional do processo, na forma do art. 89 da Lei 9.099/1995. O Ministério Público pode propô-la e incluir dentre as condições do sursis processual o tratamento psicológico do agente em hospital público, dentre outras." Ob. cit., p. 454. Essa solução proposta é interessante, à medida que haverá a conciliação entre a finalidade da pena e a peculiar situação do agente surpreendido com pornografia infantil real. Afinal, é mais razoável aplicar tratamento do que pena privativa de liberdade nessas hipóteses. E, claro, a conduta do traficante do material continuará sendo disciplinada de forma mais rigorosa. 


\section{CONCLUSÕES}

1. Em primeiro lugar, é necessário estabelecer uma diferença entre Direito e Moral, de maneira que os critérios informadores do conjunto ético ou religioso de uma sociedade, em determinada época, não pode servir como único meio de inspiração para a elaboração de normas jurídicas, principalmente na incriminação de condutas.

2. O Direito Penal, por se tratar do modo mais aflitivo e grave de interferência do Estado na vida do cidadão, deve ser informado por vetores relacionados à proteção de bens jurídicos, interesses estes a serem tutelados apenas como ultima ratio. Dessa forma, a Moral Social - e mais especificamente, a Moral Sexual - não podem ser invocadas, por si só, para o fim de incidência da norma penal.

3. O paternalismo jurídico-penal surge como a forma que o Estado encontra de impor aos cidadãos padrões de comportamento, partindo-se da premissa que o ente estatal teria o direito de invadir a esfera de intimidade/privacidade das pessoas. Tudo aquilo que, no contexto social, seja considerado prejudicial ao próprio indivíduo deve ser punido, se preciso com a força do Direito Penal.

4. No entanto, o âmbito de autonomia e a vida particular de cada um não pode sofrer interferências externas, se não estiverem presentes os critérios de proteção de bens jurídicos ou então a ocorrência de lesão a interesses de terceiros.

5. Quando se fala em comportamentos relacionados à pornografia infantil, é preciso analisar a legitimidade das previsões legais de incriminação dessas condutas à luz da mencionada necessidade de separação entre Direito e Moral, bem como da autonomia do indivíduo e do paternalismo jurídico-penal.

6. Os conceitos e o alcance do pornográfico e do obsceno devem ter em vista, sempre, a presença de elementos que apontem para a finalidade de despertar a excitação sexual da 
pessoa à qual tais materiais são dirigidos. A evolução histórica da disciplina jurídica do tema revela, no mais das vezes, a interferência indevida dos critérios moralizantes.

7. Será considerado, assim, obsceno ou pornográfico apenas aquele material que não contenha fins artísticos, educativos e científicos. Por isso, a mera exibição de nudez ou partes do corpo retratado não será tida como obscena se não existir o objetivo de estimular a libido de quem tenha contato com esse tipo de obra ou representação gráfica.

8. Os crimes de ato obsceno (art. 233 do CP) e escrito pornográfico ou obsceno (art. 234 do CP) merecem ser revogados do ordenamento jurídico, desde que haja a previsão de uma nova figura delituosa, voltada a proteger as pessoas que não queiram ter contato, por exemplo, com alguém que se masturba em público. Uma sugestão possível repousa na criação de um tipo penal nos mesmos moldes do "exibicionismo" constante do CP espanhol.

9. Os crimes sexuais devem levar em conta o alcance da noção de liberdade sexual, em duas perspectivas: positiva (plena liberdade de exercício da sexualidade segundo o desejo da pessoa, sem interferência estatal, desde que de forma consentida e não-viciada) e negativa (direito do indivíduo de não ter violada a sua vontade de exercício dessa sexualidade, por meio, por exemplo, da previsão do crime de estupro).

10. Quando se tratar de crianças e adolescentes, a questão da liberdade/capacidade sexuais merece um tratamento especial. Embora não seja plena, diante da precocidade e dos avanços culturais no mundo atual, é inegável que, a partir de certa idade, o adolescente tem uma certa discricionariedade de autodeterminar-se sexualmente.

11. O ideal é pensar a questão da vulnerabilidade dos menores por meio de critérios etários escalonados. Assim, até os doze anos de idade, a vulnerabilidade deve ser absoluta; entre os doze e os catorze anos, seria relativa; e dos catorze aos dezoito, haveria liberdade plena, desde que não estejam presentes elementos indicativos de exploração ou abuso sexuais (prostituição, por exemplo). 
12. A presunção de violência (vulnerabilidade) deve prevalecer apenas para os casos de relações sexuais cometidas com menores de doze anos, e não de catorze, conforme a redação do atual artigo 217-A do CP.

13. Pornografia infantil é todo aquele material que retrate crianças e adolescentes em contexto sexual, com a finalidade primordial de estímulo libidinoso de quem entre em contato com as imagens ou vídeos.

14. Não obstante o artigo 241-E defina pornografia infantil como todo material que contenha crianças ou adolescentes, reais ou simulados, em situação sexual, entendemos que a simulação de imagens deveria ser extirpada do conceito, visto que não houve qualquer lesão ao bem jurídico incolumidade sexual dos menores.

15. Seguindo a tendência mundial, os tipos penais relacionados com a pornografia infantil descritos no ECA sofreram uma sensível modificação por meio da Lei 11.829/08, que recrudesceu as penas previstas para os delitos de tráfico desse material, criou novos tipos penais, como a aquisição/posse/armazenamento (art. 241-B) e a mera simulação de crianças e adolescentes (art. 241-C).

16. No tocante ao delito do art. 241-B do ECA (posse de pornografia infantil real), a legitimação desse tipo penal decorre, de um lado, tanto do estímulo à indústria da pornografia infantil, quanto da proteção da imagem dos menores, buscando evitar que o possuidor desse material possa vir a exteriorizar suas fantasias sexuais no futuro (tese da instigação). De outro, procura-se proteger os menores efetivamente utilizados na filmagem, de modo que haveria uma equiparação com a figura da receptação.

17. Sobre a questão da tese da instigação, não há lastro que legitime tal fundamento, pois inexistem critérios empíricos comprovados cientificamente de comprovação de estímulo á prática de crimes sexuais mais graves. Ao contrário, há até partidários de que o contato do consumidor com essa modalidade de material serviria como arrefecimento dos desejos sxuais (tese da catarse). 
18. Acerca da receptação, o tipo penal de posse de pornografia infantil real encontra justificação, à medida que, de fato, houve a anterior lesão ao bem jurídico tutelado. No tocante aos casos de pornografia infantil simulada (ou virtual), diante da ausência de "crime" praticado previamente, tal argumento não sobrevive.

19. A mera conduta de acessar arquivos que contenham pornografia infantil não é prevista como crime, o que pode levar a situações injustas, como aquela em que o cidadão visualiza diversos tipos de vídeos ou imagens, sem baixá-las. De qualquer forma, para a caracterização do tipo, há de existir uma perpetuação no tempo ou então o dolo de apropriar-se indefinidamente do dito material.

20. A pornografia infantil virtual, como prevista no art. 241-C do ECA, alcança toda e qualquer situação em que haja a utilização de imagens de menores manipuladas (simulada) ou então até mesmo de menores inexistentes (morphing). Trata-se de uma das mais abrangentes e aparece no contexto de penalizar até mesmo os maus pensamentos.

21. O tipo penal é ilegítimo, inconstitucional, à medida que não há ofensa aos critérios de lesividade/ofensividade, bem como do devido processo legal material. Punir a mera fantasia é incondizente com os ditames de um Direito Penal em um Estado de Direito. De outra banda, a violação às imagens dos adolescentes - caso alguma entidade ou associação se sinta prejudicada com pornografia infantil simulada - deve ficar no campo da indenização civil, e não da instrumentalização do Direito Penal para "corrigir" os cidadãos.

22. A incriminação da pornografia infantil real, de outro lado, é legítima, desde que os menores utilizados tenham até catorze anos. Após essa idade, torna-se preciso verificar se houve abuso ou exploração sexuais.

23. Os consumidores de material pornográfico infantil virtual não praticam crime algum, sendo tal fato atípico. No entanto, quanto à posse de pornografia infantil real, é preciso 
verificar se caberá pena ou medida de segurança, de acordo com a presença (ou não) da capacidade de entender o caráter ilícito da conduta.

24. Para esse último grupo de pessoas, é necessário verificar se estão presentes os pressupôs de caracterização da parafilia tida como pedofilia, afinal, nem todo consumidor de pornografia infantil é um doente. Muito embora o fato de ser pedófilo, por si, não seja crime, caso haja a aquisição desse material, pode-se pensar na aplicação de um tratamento ou outra medida diversa da privação de liberdade. 


\section{REFERÊNCIAS}

\section{BIBLIOGRAFIA}

AGUADO CORREA, Teresa. El principio de proporcionalidad en derecho penal. Madrid: Edersa, 1999.

ALEXY, Robert. Teoria dos direitos fundamentais. 5. a ed. Alemã. Trad. Virgílio Afonso da Silva. São Paulo: Malheiros, 2008.

ALFAIATE, Ana Rita. A relevância penal da sexualidade dos menores. Coimbra: Coimbra, 2009.

ANDI - Comunição e Direitos. Portal sobre infância e juventude. Disponível em: http://www.andi.org.br/faq/quais-sao-os-termos-mais-apropriados-para-se-referir-a-criancas-eadolescentes-quando-se-tem-em>. Acesso em 18 de dezembro de 2012.

ANDRADE, Manuel da Costa. Consentimento e Acordo em Direito Penal. Coimbra: Coimbra, 2004.

ANTUNES, Maria João. Crimes contra menores: incriminação para além da liberdade e da autodeterminação sexual. Boletim da Faculdade de Direito, Coimbra, v. 81, p.57-71, 2005.

Argentina. Suprema Corte de Justicia de la Nación. A. 891. XLIV. Recurso de hecho. Arriola, Sebástian y otros s/ causa n. 9080, j. 25.08.2009. Disponível em: http://www.csjn.gov.ar/docus/documentos/verdoc.jsp, acesso em 04 de novembro de 2009.

ARAÚJO. António de. Crimes sexuais contra menores: entre o Direito Penal e a Constituição.Coimbra: Coimbra Editora, 2005. 
ARQUETE, Stella Regina. Iniciação sexual da adolescente. O desejo, o afeto e as normas sociais. Tese (Doutorado) apresentada ao Departamento de Pediatria da Faculdade de Medicina da USP, para a obtenção do título de Doutora em Pediatria. Ribeirão Preto, 1997, p. 13. Disponível em: http://www.nesa.uerj.br/download/TESE_STELLA.pdf.

ASSUNÇÃO e SILVA, Alexandre. Violações a princípios constitucionais e penais na legislação de combate à pornografia infantil. Revista dos Tribunais. vol. 890. São Paulo: RT, 2009, p. 444.

ÁVILA, Gustavo Noronha, GAUER, Gabriel José Chittó, GUER, Ruth Maria Chittó. Comércio de órgãos humanos: até onde vai a autonomia do indivíduo. Boletim IBCCrim, São Paulo,v. 15, no 175, Jun. 2007, p. 17-19.

ÁVILA, Humberto. Teoria dos princípios: da definição à aplicação dos princípios jurídicos. $7^{\text {a }}$ ed. São Paulo: Malheiros, 2007.

BALTIERI, Danilo Antônio; ANDRADE, Arthur Guerra. Treatment of paraphilic sexual offenders in Brazil: issues and controversies. International. Journal of Forensic Mental Health, vol. 8, $3^{\text {a }}$ ed., 2009, p. 218-233.

. Consumo de álcool e outra drogas e impulsividade sexual entre agressores sexuais.

Tese (Doutorado em Psiquiatria). Faculdade de Medicina da Universidade de São Paulo. São Paulo, 2005.

BECHARA, Ana Elisa Liberatore S. O rendimento da teoria do bem jurídico no direito penal atual. São Paulo: IBCCrim, Revista Liberdades, v. 1, nº 1. Mai./ago. 2009, p. 16-29.

BERENGER, Enrique Orts; TORRES, Margarita Roig. Concepto de material pornográfico en el ámbito penal. ReCRIM: Revista de l'Institut Universitari d'Investigació en Criminologia $i$ Ciències Penals de la UV, ISSN-e 1989-6352, nº. 2, 2009. 
BINDER, Alberto M. Pornografía: dignidad humana y represión cultural . Doctrina Penal: Teoría y prática en las ciencias penales, Buenos Aires, v. 9, 33/36, 1986, p. 615-631.

BOBBIO, Norberto. Elogio da serenidade: e outros escritos morais. Tradução Marco Aurélio Nogueira. 2. ${ }^{\text {a }}$ ed. São Paulo: Editora Unesp, 2011.

BOLDOVA PASAMAR, Miguel Ángel. Pornografía infantil en la red. Fundamento y límites de la intervención del Derecho Penal. Cidade do México: Ubijus, 2008.

El delito de facilitar pornografía a menores o incapaces (art. 186 del Código Penal). Em: SAMANIEGO, José Luis Manzares (dir.). Actualidad penal - Revista Semanal Técnicojurídica de derecho penal. Madrid: Ed. La Ley. Set.2001, p. 841-861.

BONILHA, Ínkari Coelho. O tratamento jurídico-penal do acesso não autorizado a sistema informático. São Paulo: 2006. Dissertação (Mestrado em Direito Penal). Faculdade de Direito, Universidade de São Paulo, São Paulo.

BOUYSSOU, Norma. Delito de posesión - de nuevo sobre su escenario respecto a la acción. A su vez, una consideración a tenencia de pornografía infantil para uso proprio. Em: FAYET JÚNIOR, Ney; MAYA, André Machado (org.). Ciências penais: perspectivas e tendências da contemporaneidade. Curitiba: Juruá, 2011, p. 63.

BRETAN, Maria Emilia Accioli Nobre Bretan. Violência sexual contra crianças e adolescentes medida pela tecnologia da informação e comunicação: elementos para a prevenção vitimal. São Paulo: Tese (Doutorado em Direito Penal). Faculdade de Direito, Universidade de São Paulo, São Paulo, 2012.

BRODT, Luís Augusto Sanzo. Dos crimes contra a dignidade sexual: a nova maquiagem da velha senhora. Revista de Ciências Penais, RCP 13, 2010, p. 170-193. 
BRUTTI, Roger Spode. Tópicos cruciais sobre pedofilia. Revista IOB de Direito Penal e Processual Penal, Porto Alegre, v.8, nº 47. Dez./jan. 2007/2008, p. 18-25.

CALLEGARI, André Luís. Direito Penal e proporcionalidade nos delitos sexuais como concretização dos Direitos Constitucionais. Revista Brasileira de Ciência Criminais ano 14, nov./dez. 2006

CANCIO, Manuel Meliá. Una nueva forma de los delitos contra la libertad sexual. La ley penal: Revista de derecho penal, procesal y penitenciario, $\mathrm{n}^{\circ}$ 80, v. 8, Madrid, 2011, p. 5-20.

CANTUDO, Miguel Ángel Chamocho. Sodomía. El crimen y pecado contra natura o historia de una intolerancia. Madri: Dykinson, S. L., 2012.

CARR, John. The internet dimension of sexual violence against children: protecting children from sexual violence. A comprehensive approach”. Publishing Editions. Concil of Europe. November, 2010, p. 17.

—. Child pornography and the internet, disponível em www.make-itsafe.net/...Child_pornography_internet_Carr2004.pdf.

COCO, Giovanni. Può costituire reato la detenzione di pornografia minorile? in Rivista Italiana di Diritto e procedura penale, Anno XLIX, Fasc. 3, jul./set. 2006, p. 874.

CORTINA, José Miguel de la Rosa. Los delitos de pornografía infantil: aspectos penales, procesales y criminológicos. Valencia: Tirant to Blanch, 2011.

COSTA, Francisco Ilídio Ferreira. Da moral e da religião - ausência de relação destas com o direito penal no Estado Democrático de Direito. Em Revista do Curso de Direito de Ituiutaba - UEMG - ano 4, nº 8, p.95-100, jul./dez 2001. 
COSTA, Helena Regina Lobo. A dignidade humana. São Paulo: Revista dos Tribunais, 2008.

COSTA, Leonardo Luiz de Figueiredo. Limites constitucionais do direito penal. Rio de Janeiro: Lumen Juris, 2007.

COSTA JR., Paulo José da. O direito de estar só. Tutela penal da intimidade. $2^{\text {a }}$ ed. São Paulo: Revista dos Tribunais, 1995.

CRUZ, Anselmo Firmo de Oliveira. Pedofilia: até onde está o crime? Disponível em: www.ibccrim.org.br/site/artigos/ imprime.php?jur id=544.

DENNY, Ercílio A. Interpretar e Agir. Piracicaba: Opinião, 2002.

DIAS, Maria do Carmo Saraiva de Menezes da Silva Dias. Crimes sexuais com adolescentes: particularidades dos artigos 174 e 175 do Código Penal português. Coimbra: Almedina, 2006.

DIAS, Jorge de Figueiredo. Dos crimes contra Liberdade e Autodeterminação sexual. Em: DIAS, Jorge de Figueiredo (org.). Comentário Coimbrense do Código Penal. Parte Especial. Tomo I, Artigos $131^{\circ}$ a 201º, Coimbra: Coimbra, 1999.

DIAZ-BENÍTEZ, María Elvira. Nas redes do sexo. Os bastidores do pornô brasileiro. Rio de Janeiro: Zahar, 2010.

DÍEZ RIPOLLÉS, J. L.: Las últimas reformas en el Derecho penal sexual. Em: Estudios Penales y Criminológicos, n. $^{\circ}$ XIV, 1991, p. 90-91.

DOTTI, René Ariel. A liberdade e o direito à intimidade. Revista de Informação Legislativa, abr./jun. 1980, Brasília/DF, p. 130. Disponível na Biblioteca Digital do Senado Federal: http://www2.senado.gov.br/bdsf/item/id/181214. 
EAGLEMAN, David. Incógnito: as vidas secretas do cérebro. Trad. Ryta Vinagre. Rio de Janeiro: Rocco, 2012.

ESQUINAS VALVERDE, Patricia. El tipo de mera posesión de pornografía infantil en el Código Penal Español - art. 189.2: razones para su destipificación. Revista de Derecho Penal y Criminologia, $2^{\mathrm{a}}$ Epoca, $\mathrm{n}^{\circ}$ 18, 2006.

ESTELLITA, Heloisa. Paternalismo, moralismo e direito penal: alguns crimes suspeitos em nosso direito positivo. Revista Brasileira de Filosofia, São Paulo, vol. LVI, fasc. 227, p. 333341, Jul./set. 2007.

FAGGIONI, Luiz Roberto Cicogna. O obsceno, o pornográfico e seu tratamento no Direito Penal. São Paulo: Tese (Doutorado em Direito Penal). Faculdade de Direito, Universidade de São Paulo, São Paulo, 2002.

FAINBERG, Marcelo H. Prostitución, pornografía infantil y trata de personas. Buenos Aires: Ad-Hoc, 2010, p. 175-219.

FARIAS, Alexandre Ramalho de. A incidência da normativa internacional na delimitação do bem jurídico protegido nos delitos relativos à pornografia infantil. Revista Justiça e Sistema Criminal, Curitiba, v. 2, n. ${ }^{\circ}$ 3, Jul./dez. 2010, p. 159-194.

FEINBERG, Joel. Harm to others: the moral limits of the criminal law, vol. one. Nova York: Oxford University Press, 1986.

_. Offense to others: the moral limits of the criminal law, vol. two. Nova York: Oxford University Press, 1986. 
FERNÁNDEZ, David L. Morillas. Los delitos de pornografía infantil en el derecho comparado. Em: Cuadernos de política criminal. Segunda época, Madrid: Centro de Estudios Superiores de Especialidades Jurídicas, 2004, p. 31-81.

FERNÁNDEZ, David L. Morillas, Análisis dogmático y criminológico de los delitos de pornografia infantil: especial consideración de las modalidades comisivas relacionadas con internet. Madri: Dykinson, 2005.

FERREIRA, Ivette Senise. A intimidade e o direito penal. Revista Brasileira de Ciências Criminais, São Paulo, v. 2, nº 5, jan./mar. 1994, p. 96-106.

FERRACUTI, Franco. BRUNO, Francesco. GIANNINI, Maria Cristina. Criminologia e psichiatria forense delle condote sessuali normali, abnormi e criminali. Milão: Giuffre, 1998.

FERRAJOLI, Luigi. A questão do embrião entre direito e moral. Revista do Ministério Público. Lisboa: v. 24, Fascículo 94, ano 24, Abr.-jun, 2003, p. 11-12.

FERREIRA, Pedro Paulo da Cunha. Artigo 241-C da lei $n^{\circ} 11.829 / 2008$ : a pornografia simulada e a questão da ofensividade penal na sociedade de risco. Boletim IBCCRIM. São Paulo: IBCCRIM, ano 17, n. ${ }^{\text {2 } 208}$. Mar. 2010, p. 18-19.

; VIEIRA, Lara Maria Tortola Flores. Dos crimes relativos à simulação de pornografia infanto-juvenil: paternalismo moralista ou tutela penal da dignidade sexual de crianças e adolescentes. Boletim IBCCRIM. São Paulo: IBCCRIM, ano 20, n. ${ }^{\circ}$ 232, p. 11, mar. 2012.

Um estudo acerca das relações entre a política criminal da sociedade de risco e a mídia: abordagens críticas de suas influências em face da tutela penal da dignidade sexual infantojuvenil. Revista Liberdades n. ${ }^{\circ} 10$ - Mai./ago. 2012. Disponível em: http://www.ibccrim.org.br/site/revistaLiberdades/_pdf/10/artigo4.pdf. 
FRANCO, Alberto Silva. Crimes contra os Costumes. Em: FRANCO, Alberto Silva; STOCCO, Rui (org.). Código penal e sua interpretação jurisprudencial, vol. II. Parte Especial. São Paulo: RT, 2001.

FURLANETO NETO, Mário. Pedofilia: das bases etimológica, médico-legal e psiquiátrica aos reflexos no direito penal. Boletim IBCCrim, São Paulo, v.12, nº 145. Dez. 2004, p. 6-7.

GARCIA DA SILVA, Camila. Pornografia simples e qualificada. Revista de Ciências Penais, ano $9, \mathrm{n}^{\circ} 16,2012$, p. 253.

GARCIA, Roberto Soares. Notas sobre pornografia infantil ou juvenil praticada por meio da internet. Disponível em: http://www.ibccrim.org.br, em 09.12.2001.

GIMBERNAT ORDEIG, Enrique. La Reforma de Los Delitos Sexuales. Em: Prólogo a la quinta edición del Código Penal Espanhol. Barcelona: Tecnos, 1999.

GOMES, Luiz Flávio. Divulgação de cenas de sexo na Internet, envolvendo crianças e adolescentes, é crime? Revista IOB de Direito Penal e Processual Penal, Porto Alegre, v. 8, no 47, p.16-17, dez./jan. 2007-2008.

Presunção de violência nos crimes sexuais. São Paulo: Revista dos Tribunais, 2001 (Série 'As ciências criminais no século 21; v. 4).

GOMES, Mariângela Gama Magalhães. O princípio da proporcionalidade no direito penal. São Paulo: Revista dos Tribunais, 2003.

GOTI, Jaime E. Malamud. La pornogafía y el derecho penal (Un ejemplo de paternalismo). Em: Doctrina Penal. Teoria y prática en las ciencias penales, Buenos Aires: Depalma, 1984, p. 495-500. 
GRECO, Alessandra Orcesi Pedro; RASSI, João Daniel. $2^{\mathrm{a}}$ ed. Crimes contra a dignidade sexual. São Paulo: Atlas, 2011.

GRECO, Luis. A crítica de Stuart Mill ao paternalismo. Revista Brasileira de Filosofia, São Paulo, vol. LVI, fasc. 227, p. 321-332, Jul./set. 2007.

; Revista Brasileira de Ciências Criminais, São Paulo, v. 18, nº 82, p.165-185, jan./fev. 2010.

; TÓRTIMA, Fernanda Lara (org.) O bem jurídico como limitação do poder estatal de incriminar? Rio de Janeiro: Lumen Juris, 2011.

. Posse de droga, privacidade, autonomia: reflexões a partir da decisão do Tribunal Constitucional argentino sobre a inconstitucionalidade do tipo penal de posse de droga com a finalidade de próprio consumo. Revista Brasileira de Ciências Criminais, São Paulo, v. 18, nº 87, p.84-102, nov./dez., 2010.

Princípio da ofensividade e crimes de perigo abstrato. Revista Brasileira de Ciências Criminais, São Paulo, v. 12, nº 49, p. 89-147, Jul./ago. 2004.

. Tem futuro a teoria do bem jurídico? Reflexões a partir da decisão do Tribunal Constitucional Alemão a respeito do crime de incesto ( $\$ 173$ Strafgesetzbuch). Revista Brasileira de Ciências Criminais, São Paulo, v. 18, no 82, p.165-185, jan./fev. 2010.

GUDÍN RODRÍGUEZ-MAGARIÑOS, Faustino. Medidas legales para la salvaguarda de la infancia frente a los crímenes de pedofilia. Revista de Derecho y Proceso Penal, Navarra, $\mathrm{n}^{\circ}$ 20, p. 79-100, 2008.

GUISADO MORENO, Ángela. El consumo de pornografía infantil en Internet. El lado oscuro de la red. $R C E 81,2007$, p. 44. 
HART, Herbert L. A. Direito, liberdade, moralidade. Tradução de Gérson Pereira dos Santos. Porto Alegre: Fabris, 1987.

HASSEMER, Winfried. ¿Puede haber delitos que no afecten a un bien jurídico penal? Em: HEFENDEL, Roland. La teoría del bien jurídico. Madri: Ed. Marcial Pons, 2007, p.103.

HEFENDEL, Roland. (org.) La teoría del bien jurídico ¿Fundamento de legitimatión del Derecho penal o juego de abalorios dogmático? Madri: Marcial Pons, 2007.

HIRSCH, Andreas von. Paternalismo direto: autolesões devem ser punidas penalmente? Revista Brasileira de Ciências Criminais, São Paulo, v. 15, nº 67, p. 11-28, Jul./ago. 2007.

HUNGRIA, Nelson; LACERDA, Romão C. de; FRAGOSO, Heleno Cláudio. Comentários ao Código Penal. Vol. VIII. Arts. 197 a 249. $5^{\text {a }}$ ed. Rio de Janeiro: Forense, 1981.

JABUR, Gilberto Haddad. Liberdade de pensamento e direito à vida privada. São Paulo: Revista dos Tribunais, 2000, p.255.

JAKOBS, Günter, CANCIO MELIÁ, Manuel. Derecho penal del enemigo, Madri: Civitas, 2003.

JORIO, Israel Domingos. Vulnerabilidade relativa, sim! Boletim IBCCRIM. São Paulo: IBCCRIM, ano 20, n. 236, jul., 2012, p. 8-9.

KÜHL, Kristian. Derecho penal y moral. Criminalidad, evolución del derecho penal y crítica al derecho penal en la actualidad. ZAFFARONI, Eugenio Raúl...[et. al.]. Ciudad Autonoma de Buenos Aires: Del Puerto, p. 197-211, 2009.

LANCMAN, Valeria A. La pornografía infantil en internet. Em: Revista de Derecho Penal, Procesal Penal y Criminologia. Número 5/6. Buenos Aires: Jurídicas Cuyo. p. 291-319, 2004. 
LANNING, Keneth V. Child Molesters: A Behavioral Analysis For Professionals Investigating the Sexual Exploitation Of Children”. Fifth Edition. National Center for Missing and Exploited Children, 2010, p. 29.

LARIZZA, Silvia. Laicidade e Direito Penal. Em: Direito Penal e Política Criminal no Terceiro Milênio: perspectivas e tendências. D’AVILLA, Fabio Roberto (org.). Pontifícia Universidade Católica do Rio Grande do Sul. Porto Alegre: EdiPucRS, 2009.

LEITE, Inês Ferreira. Pedofilia: repercussões das novas formas de criminalidade na teoria geral da infracção. Coimbra: Almedina, 2004.

LEITE JÚNIOR, Jorge. Das maravilhas e prodígios sexuais. Uma análise da pornografia hard core "bizarra”. 2003. Orientadora: Maria Celeste Mira. Dissertação (Mestrado em Ciências Sociais) - Pontifícia Universidade Católica de São Paulo, São Paulo, 2003.

LEMOS, Ronaldo. Então, somos todos criminosos: em nome do combate à pedofilia, projeto de lei criminaliza práticas triviais na Internet com até 4 anos de prisão. 2008. Em: O Estado de S. Paulo, p. J7, 13.07.2008.

LEVICK, Martha. Prosecuting sexting as child pornography. Disponível em http://scholar.valpo.edu/vulr/vol44/iss4/2. Acesso em 12 de outubro de 2012.

LOPES, José Mouraz. Os crimes contra a liberdade e autodeterminação sexual no Código Penal. 4. ${ }^{\text {a }}$ ed., Coimbra: Coimbra Editora, 2008.

LÓPEZ, Erick Gómez Tagle. Los derechos humanos y la pornografia y prostitución infantiles. Criminalia, Academia Mexicana de Ciencias Penales, Año LXIX, nº3. 2003, p. 159-179. 
LÓPEZ, Juan José Martín-Casallo. Pornografía infantil e internet: la respuesta en el Código Penal Español. Em: Problemática jurídica en torno al fenómeno de internet. Madrid: Consejo General del Poder Judicial. 2000, p. 177-205.

LUZÓN PEÑA, Diego-Manuel. Libertad, culpabilidad y neurociencias. InDret 3/2012, Barcelona, jul./12. Disponível em http://www.indret.com/pdf/904a.pdf.

LYRA, Roberto. Moralidade sexual e polícia de costumes. Revista Brasileira de Criminologia e Direito Penal, Rio de Janeiro, v. 4, nº 15, p.87-90, out./dez. 1966.

MAGARIÑOS, Faustino Gudín Rodríguez. Medidas legales para salvaguarda de la infancia frente a los crímenes de pedofilia. Revista de Derecho y Processo Penal. Navarra: Aranzadi, fascículo 20, p.79-100, 2009.

MANNA, Adelmo. Profili problematici della nuova legge in tema di pedofilia. L'Indice Penale, Padova, v. 2, n. ${ }^{\circ}$ 1, jan./abr. 1999, p. 48.

MARTINELLI, João Paulo Orsini. Paternalismo na lei de drogas. Revista Liberdades, São Paulo, $\mathrm{n}^{\mathrm{o}}$ 2, p.13-24, set./dez. 2009.

MEIER-PFLUG, Samantha Ribeiro. Liberdade de expressão e discurso do ódio. São Paulo: Revista dos Tribunais, 2009.

MACHADO, Martha de Toledo. Proibições de excesso e proteção insuficiente no direito penal: a hipótese dos crimes sexuais contra crianças e adolescentes. São Paulo: Verbatim, 2008.

MELO, Jose Soares de. Receptação. São Paulo: Revista dos Tribunais, 1937.

MESA, Gloria Patrícia Lopera. Princípio de proporcionalidad y ley penal. Madri: Centro de Estudios Políticos y Constitucionales, 2006. 
MILL, John Stuart. Sobre a liberdade. Trad.: Ari. R. Tank Brito. São Paulo: Hedra, 2010.

MIR PUIG, Santiago. Derecho penal. Parte general. $2^{\mathrm{a}}$ ed. Barcelona: Promociones Publicaciones Universitarias, 1985.

MIRANDA, Rosângelo Rodrigues de. Ensaio sobre a tutela da autonomia privada na Convenção Americana de Direitos Humanos. Revista Jurídica do Ministério Público do Estado de Minas Gerais no 3, p. 179-196, Belo Horizonte, jan./dez. 2001.

MORAES, Bismael B. Pedofilia não é crime. Boletim IBCCrim,. São Paulo, v.12, nº 143, p. 3, out. 2004.

MORICI, Silvia. Homossexualidade: um lugar na história da intolerância social, um lugar na clínica. Em: GRAÑA, Roberto B. (org.), Homossexualidade. Formulações psicanalíticas atuais, Porto Alegre: ARTMED, 1998.

MORÓN LERMA, E. Internet y Derecho Penal: Hacking y otras conductas ilícitas en la Red. Pamplona: Aranzaldi, 1999.

NATALE, Domenico de. Attività di contrasto alla pedopornografia on line: aspetti problematici della responsabilità delle persone fisiche e degli enti. Em: Revista Trimestrale di Diritto Penale dell'Economia. Padova, no 1-2, 2010, p. 1-23.

NATSCHERADETZ, Karl Prelhaz. O Direito Penal Sexual: conteúdo e limites. Coimbra: Almedina, 1985.

NOBOCOV, Isabela. O cientista que só pensava naquilo. Revista Veja, ed. 1.876, 20 de outubro de 2004. Disponível em: 〈http://veja.abril.com.br/201004/p_094.html〉. Acesso em 11 de setembro de 2012 . 
NUCCI, Guilherme de Souza. Crimes contra a dignidade sexual: comentários à Lei 12.015/2009. São Paulo: Revista dos Tribunais, 2009.

PASCHOAL, Janaina Conceição. Constituição, criminalização e direito penal mínimo. São Paulo: Revista dos Tribunais, 2003.

O consumo de prostituição infantil já é crime no Brasil. Boletim IBCCRIM. São Paulo: IBCCRIM, ano 20, n. 236, jul., 2012, p. 2-3.

PERET, Eduardo. Percepções da sexualidade: anime e mangá. Revista ELO - Grupo de Pesquisa em Comunicação Interculturalda UERJI. Ed. 4. Ano 1. Rio de Janeiro: Laboratório de Comunicação Integrada (LCI) do Departamento de Relações Públicas da Faculdade de Comunicação Social da UERJ, 2009. Disponível em www.elo.uerj.br/pdfs/ELO_Ed4_Artigo_animemanga.pdf.

PEREIRA, Elizabeth Bayma. Castração química: análise do Projeto de Lei n552/2007 à luz da Constituição Federal. Disponível em: http://jus.uol.com.br/revista/texto/17166/castracaoquimica.

PIERANGELI, José Henrique. Manual de direito penal brasileiro. Vol. 2. Parte Especial (arts. 121 a 361). 2. ed. rev. atual. e compl. São Paulo: Revista dos Tribunais, 2007.

PRADO, Luiz Regis. Bem jurídico penal e Constituição. $2^{a}$ ed. São Paulo: Revista dos Tribunais, 2002.

Curso de direito penal brasileiro, vol. 3: parte especial, arts. 184 a 288. $2^{\mathrm{a}}$ edição. São Paulo: Revista dos Tribunais, 2002.

PRATS, Fermín Morales. La intervención penal en la red. La represión penal Del tráfico de pornografía infantil: estudio particular. Em: RODRÍGUEZ, Laura Zúñiga et alli (coord.). Derecho penal, sociedad y nuevas tecnologías. Madri: Editorial Colex, 2001, p. 111-133. 
MORALES PRATS, Fermín. GARCÍA ALBERO, R. Comentarios a la Parte Especial del Derecho Penal, Pamplona: Aranzaldi, 7. ${ }^{\mathrm{a}}$ ed., 2008.

QUEIROZ, Paulo de Souza. A propósito da pedofilia. Boletim IBCCrim, São Paulo, v.12, no 138. Maio 2004, p. 5.

Do caráter subsidiário do Direito penal: lineamentos para um direito penal

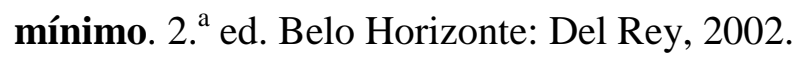

REALE, Miguel. Noções preliminares de Direito. $27^{\text {a }}$ ed. São Paulo: Saraiva, 2002.

RECALDE, José Ramón. La autonomía del individuo y la promoción de la vida buena. Eguzkilore: Cuaderno del Instituto Vasco de Criminología, San Sebastián, 5 ext., p.265-275, dez.-1992.

REINALDO FILHO, Demócrito. A pornografia infantil virtual e as dificuldades jurídicas para combatê-la - o caso do 'second life'. Em: Revista IOB de Direito Penal e Processual Penal n ${ }^{\circ}$ 47. Jan.2008, p. 7-15

Pornografia infantil pela internet. Divulgação: breves comentários à Lei no 10.764/03. Revista Síntese de Direito Penal e Processual Penal, Porto Alegre, v. 4, no 24, p.40-43, fev./mar. 2004.

RELATÓRIO. "Pornografia Infantil - Legislação Modelo \& Revisão Global”, 6ª edição, 2010, ICMEC. Centro Internacional para Crianças Desaparecidas e Exploradas. Disponível em http://www.icmec.org/en_X1/icmec_publications/6th_Edition_Portuguese_Final_.pdf, acesso em 18 de dezembro de 2012.

ROJO, Juan Carlos García. La realidad de la pornografía infantil en internet. Revista de derecho penal y criminología, $2^{\mathrm{a}}$ época, $\mathrm{n}^{\circ}$ 9., Madri, 2002, p. 211-251. 
RODRÍGUEZ, Laura Zúñiga. RODRÍGUEZ, Cristina Méndez. DÍAS-SANTOS, M. ${ }^{\text {a }}$ Rosário Diego. Derecho penal, sociedad y nuevas tecnologias. Madri: Colex, 2001, p.111-133.

ROSA, Júlio César Fontana. Pedofilia. Em: Revista do Curso de Direito - Espírito Santo do Pinhal, São Paulo, v.3, p. 35-49, Jan/dez. 2011.

ROXIN, Claus. ARZT, Gunther. TIEDEMANN, Klaus. Introdução ao Direito penal e ao Processo Penal. Belo Horizonte: Del Rey, 2007.

ROXIN, Claus. A proteção de bens jurídicos como função do direito penal. Coordenação e Tradução de André Luís Callegari e Nereu José Giacomolli. Porto Alegre: Editora Livraria do Advogado, 2006.

Que comportamentos pode o Estado proibir sob ameaça de pena? Sobre a legitimação

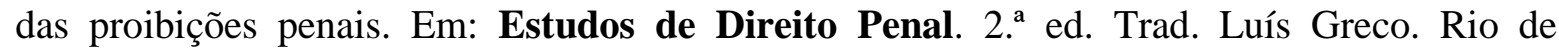
Janeiro: Renovar, 2008.

. Dependencia e independencia del Derecho Penal con respecto a la política, la filosofía, la moral y la religión. Em: Anuário de derecho penal y ciencias penales, tomo LIX, Madri: Ministerio de Justicia (Centro de publicaciones) y Boletín Oficial del Estado. 2008, p. 5-24.

. Derecho penal. Parte general. Tomo I. Madri: Editorial Civitas, 1997.

SALLES, Romeu de Almeida. Furto, roubo e receptação: indagações, doutrina, jurisprudência, prática. São Paulo: Saraiva, 1995.

SANCHES TOMAS, Jose M. Los abusos sexuales en el Código Penal de 1995: em especial sobre o menor de doce años y abusando de transtorno mental. Cuadernos de Política Criminal. Madri: Edersa, 1997, v. 61. 
SEGRE, Marco; SILVA, Franklin Leopoldo e SCHARAMM, Fermin R. O contexto histórico, semântico e filosófico do princípio de autonomia. Bioética, Brasília, v. 6, nº 1, p.15-23, 1998.

SILVA, Marcelo Sarsur Lucas da. Obsceno, explícito: repensando a pornografia como problema jurídico-penal. Belo Horizonte: 2010. Conclusão da matéria "Temas de Direito Penal: O Corpo - Estudos" do curso de pós-graduação em Direito. Universidade Federal de Minas Gerais.

SILVA, Rita de Cássia Lopes da. Crimes contra a criança e o adolescente e as inovações do Estatuto da Criança e do Adolescente. Ciências Penais: Revista da Associação Brasileira de Professores de Ciências Penais, São Paulo, v. 6, n 10, p. 320-346, jan./jun. 2009.

SILVA, Tadeu Antonio Dix. Liberdade de expressão e direito penal no estado democrático de direito. São Paulo: IBCCRIM - Instituto Brasileiro de Ciências Criminais, 2000. v. 15 (Monografias/IBCCRIM; v. 15).

_. Crimes sexuais; reflexões sobre a Nova Lei n. $^{\circ}$ 11.106/2005. Leme: J.H. Mizuno, 2006.

SILVA. Virgilio Afonso da. Direitos fundamentais. Conteúdo essencial, restrições e eficácia. São Paulo: Malheiros, 2009.

SILVEIRA, Renato de Mello Jorge. Crimes sexuais: bases críticas para a reforma do direito penal sexual. São Paulo: Quartier Latin, 2008.

Por um novo direito penal sexual: a moral e a questão da honestidade. Revista Brasileira de Ciências Criminais, São Paulo, $\mathrm{n}^{\mathrm{o}}$ 33, p.133-158, jan./mar. 2001.

SIMANTOB, Fábio Tofic. Delitos virtuais: o lugar do crime na visão dos tribunais. Revista do Advogado, ano XXXII, n. ${ }^{\circ} 115$, p. 61/67, abr. 2012. 
STEARNS, Peter N. História da sexualidade. São Paulo: Contexto, 2010.

SYDOW, Spencer Toth. Delitos informáticos próprios: uma abordagem sob a perspectiva vitimodogmática. São Paulo: 2009. Dissertação (Mestrado em Direito Penal). Faculdade de Direito, Universidade de São Paulo, São Paulo.

__. "Pedofilia virtual” e considerações críticas sobre a Lei 11.829/08. São Paulo: IBCCrim, Revista Liberdades, vol. 1., $n^{o}$ 1. Mai./ago. 2009, p. 46-45.

TAVARES, Juarez. Teoria do injusto penal. Belo Horizonte: Del Rey, 2002. Critérios de seleção de crimes e cominação de penas. Revista Brasileira de Ciências Criminais, São Paulo: RT, número especial de lançamento, dez. 1992, p. 75-87.

TERUELO, Javier Gustavo Fernández. Derecho penal e internet: especial consideración de los delitos que afectan a jóvenes y adolescentes. Valladolid: Lex Nova, 2011.

TOMILlO, Manuel Gómez. Derecho Penal Sexual Y Reforma Legal: análisis desde una perspectiva político criminal, Revista Electrónica de Ciencia Penal y Criminología - ISSN 1695-0194, RECPC 07-04 (2005).

TRINDADE, Jorge; BREIER, Ricardo Ferreira. Pedofilia: aspectos psicológicos e penais. Porto Alegre: Livraria do Advogado, 2007.

VIDAL, Luis Fernando Camargo de Barros. Crimes contra a criança e o adolescente: Lei 10.764/2003. São Paulo: IBCCRIM - Instituto Brasileiro de Ciências Criminais, 2004. 3 v. (Curso de atualizações legislativas - vídeo).

WORTLEY, Richard; SMALLBONE, Stephen. Child Pornography on the Internet. ProblemOriented Guides for Police. Disponível em http://www.cops.usdoj.gov/ Publications/e04062000.pdf, acesso em 21 de outubro. 
ZACHARIAS, Manif e Elias, Dicionário de Medicina Legal, Ibrasa - Champagnat, 1991.

\section{MATÉRIAS JORNALÍSTICAS}

Folha de São Paulo - Matérias:

(i) Pedófilos no limite. 14 de agosto de 2012. Caderno "equilíbrio". p. 4-6.

(ii) Apple censura título de livro feminista de Naomi Wolf. 15 de setembro de 2012. Caderno "ilustrada" - p. 7.

(iii) A caixa de Pandora. Entrevista de Jorge Coli. 23 de setembro de 2012. Caderno “ilustríssima”.p. 3.

\section{LINKS CONSULTADOS}

Anteprojeto do Código Penal - http://s.conjur.com.br/dl/anteprojeto-codigo-penal.pdf

Campanha da OAB sobre Pedofilia - http://www.oabsp.org.br/noticias/2005/05/17/2980/

CONAR - http://www.conar.org.br

Entrevista Danilo Baltieri. Estado de São Paulo - http://www.gtpos.org.br/ index.asp?Fuseaction=Informacoes $\&$ ParentId=511\&area $=28 \& p u b=167$

_. Revista Isto é - http://www.istoe.com.br/reportagens/194141_CERCO+AOS+ $\underline{\text { PEDOFILOS }}$ 
Legislação Italiana - http://www.bancaditalia.it/UIF/altre-funzioni/pedopornografia/l-2006$\underline{38 . p d f}$

Marco Civil da Internet - http://g1.globo.com/politica/noticia/2012/12/votacao-do-marco-civilda-internet-e-adiada-pela-sexta-vez-na-camara.html http://edemocracia.camara.gov.br/web/marco-civil-da-internet/noticias

“On Liberty” - prefaciado por Celso Lafer - http://pt.scribd.com/doc/105613644/00171-Sobre$\underline{\text { a-Liberdade }}$

Pesquisa sobre consumo de pornografia infantil (Suíça) http://www.swissinfo.ch/por/top_news/Consumo_de_pornografia_infantil_e_violencia_sexual . html?cid=7516398

Portal UOL - http://economia.uol.com.br/ultimas-noticias/redacao/2012/04/04/anunciopornografico-e-abusivo-e-banido-na-inglaterra.jhtm . http://educacao.uol.com.br/noticias/2012/10/04/garota-bissexual-e-impedida-de-assistiraula-por-usar-camiseta-eu-gosto-de-vagina-nos-eua.htm

"Relatório Kinsey" - http://pt.wikipedia.org/wiki/Alfred_Kinsey\#O_Relat.C3.B3rio_Kinsey 